DENIS CAMARGO PASSEROTTI

\title{
O ORÇAMENTO COMO INSTRUMENTO DE INTERVENÇÃO NO DOMÍNIO ECONÔMICO
}

MESTRADO EM DIREITO ECONÔMICO E FINANCEIRO

Universidade de São Paulo

Faculdade de Direito

São Paulo, 2014 


\section{O ORÇAMENTO COMO INSTRUMENTO DE INTERVENÇÃO NO DOMÍNIO ECONÔMICO}

Dissertação apresentada à Comissão Julgadora da Faculdade de Direito da Universidade de São Paulo, como exigência parcial para a obtenção do título de Mestre em Direito Econômico e Financeiro, subárea de Direito Econômico, sob a orientação do Professor Titular Regis Fernandes de Oliveira.

Universidade de São Paulo

Faculdade de Direito

São Paulo, 2014 
Banca Examinadora:

Orientador: Professor Titular Regis Fernandes de Oliveira 
À minha amada e eterna esposa Francine, confidente e companheira de todos os momentos, e às minhas filhas, Valentina e Sofia, razões de meu viver e fontes de inspiração. 


\section{AGRADECIMENTOS}

Ao Professor Doutor Regis Fernandes de Oliveira, meu orientador, pelo tempo dedicado ao aprimoramento de meus estudos, pelas aulas proferidas, ricas em conhecimento e saber, que em muito me auxiliaram e contribuíram não apenas para a conclusão do presente trabalho, mas, fundamentalmente, para minha formação pessoal e acadêmica. Além dos preciosos ensinamentos sobre o Direito e a Filosofia, ficarão para sempre marcadas as lições de vida.

À Doutora Luiza Nagib Eluf, pelo apoio e confiança.

Ao amigo e Professor Flávio Rubinstein, com quem tive o prazer de conviver durante as aulas ministradas pelo Professor Regis na graduação, e cujos conselhos e sugestões muito contribuíram na realização deste trabalho.

Aos amigos que conquistei durante esta jornada, e que, por serem tantos, declino de mencioná-los para evitar cometer a injustiça de esquecer-me de algum deles.

Aos meus pais Sergio e Ana Luiza, por tudo que sempre fizeram por mim, pela dedicação constante à minha vida, por estarem e sempre se fazerem presentes, permitindo que os desafios da vida se tornem mais fáceis ou assim se mostrem.

Aos meus irmãos, Daniela, Carlo e Larissa, especialmente ao meu parceiro de todos os momentos, Carlo, pelos conselhos e palavras de incentivo.

À minha esposa Francine, pela paciência, apoio, incentivo e conselhos, determinantes para a conclusão de mais esta etapa em minha vida.

Às minhas meninas, Valentina e Sofia, por tê-las privado de minha presença e por existirem em minha vida. 


\section{RESUMO}

Este trabalho versa sobre a utilização do orçamento público como instrumento de intervenção no domínio econômico, demonstrando, em síntese, de que forma o Estado utiliza, ou ao menos deveria utilizar, o orçamento público como instrumento de planejamento de suas ações e de intervenção na atividade desempenhada pela iniciativa privada. Tem-se por objetivo contribuir para a compreensão jurídica de diversas questões atinentes à elaboração e execução da peça orçamentária federal, aos reflexos causados na economia e na atividade desempenhada pela iniciativa privada, especialmente no que toca à realização das receitas e despesas públicas, à elaboração das leis orçamentárias - Plano Plurianual (PPA), Lei Orçamentária Anual (LOA) e Lei de Diretrizes Orçamentárias (LDO) - e, também, aos interesses, às paixões e ideologias envolvidas em todo o processo financeiro. Para tanto, inicialmente, estuda o papel do Estado, distinguindo os campos de atuação privada e aquele reservado à Administração Pública, os modos de intervenção e aqueles aplicados à hipótese analisada, para, em seguida, proceder à análise da peça orçamentária, sua concepção atual e relevância para a iniciativa privada, o que possibilita, então, tratar de questões que envolvam as receitas públicas, em específico as tributárias e as despesas públicas. Por fim, trata do crédito público e, com isso, procura evidenciar de que forma, sob a ótica do orçamento público e nos limites legais de atuação do Estado, as previsões constantes do orçamento podem funcionar como instrumento de promoção, incentivo e estímulo, ou, em sentido contrário, limitar, frear ou desestimular o crescimento econômico e a atividade desenvolvida pela iniciativa privada.

Palavras-chave: Administração Pública. Orçamento público. Planejamento. Receita pública. Despesa pública. Dívida pública. Subvenção econômica. Intervenção no domínio econômico. 


\begin{abstract}
This paper deals with the use of public budget as means of intervening in the economic control, demonstrating, in summary, how the Government uses, or at least should use, the public budget as means of planning its actions and any intervention in activities that the private initiative performs. The purpose is to contribute to the legal understanding of various issues pertaining to federal budget preparation and execution, the reflection caused to the economy and the activity performed by the private initiative. It especially regards the realization of public revenues and expenses, preparation of budgetary laws - Multiannual Plan (PPA), Annual Budgetary Law (LOA) and Budgetary Directives Law (LDO) -, as well as, interests, passions and ideology involved along the entire financial process. Therefore, it is initially assessed the Government role, distinguishing the fields reserved to private sector and that to Public Authorities; moreover, the intervention modalities and those applied to event of levy analyzed, to, then, proceed to the budget analysis, its current design and relevance for the private initiative. It allows the address of issues comprising public revenues, specifically, tax revenues and public expenses. Finally, it regards public credit and, it seeks to evidence how, from the public budget perspective and within the legal boundaries of Government performance, the forecast included to the budget may operate as instrument of promotion, incentive and motivation, or, otherwise, limit, hinder or discourage economic growth and private sector activities.
\end{abstract}

Keywords: Public Authorities. Public Budget. Planning of actions. Public revenue. Public Expenditure. Means of intervening in the economic control. 


\section{SUMÁRIO}

INTRODUÇÃO ..................................................................................................................... 11

10 ESTADO INTER VENCIONISTA ........................................................................... 15

1.1 Do "liberalismo" ao intervencionismo estatal e a ordem econômica ................. 15

1.2 Campo de atuação privada e campo de atuação reservado à Administração Pública: principais distinções ......................................................................................... 22

1.3 Os objetivos da intervenção exercida pelo Estado sobre o domínio econômico 33

1.4 Modos de intervenção ................................................................................................ 36

1.4.1 Classificações propostas pela doutrina ..........................................................3 37

1.4.2 Classificação adotada ............................................................................... 42

1.5 Intervenção, ideologia e dominação .................................................................. 46

2. O ORÇAMENTO PÚBLICO COMO INSTRUMENTO DE PLANEJAMENTO E

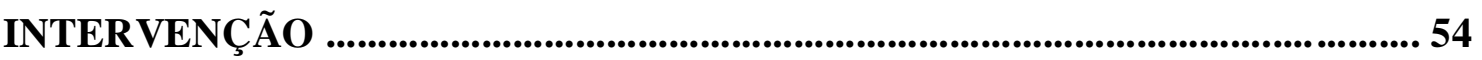

2.1 Concepção atual de orçamento público ........................................................................ 54

2.2 A relevância, na atualidade, do debate da natureza jurídica da lei

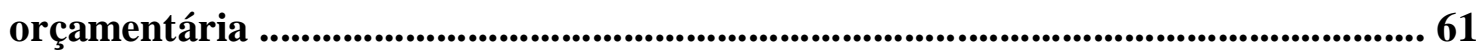

2.3 Planejamento e conteúdo da lei orçamentária ..................................................... 66

2.3.1 Conceito de planejamento ....................................................................................... 67

2.3.2 A lei orçamentária como instrumento de planejamento ................................ 68

2.3.2.1 Plano plurianual .................................................................................... 75

2.3.2.2 As diretrizes orçamentárias ................................................................ 80 
2.3.3 A periodicidade do orçamento (princípio da anualidade) e sua relevância para o domínio econômico 88

2.4 O orçamento na Constituição de 1988 e sua interação com o sistema econômico

2.5 A elaboração da peça orçamentária e os interesses envolvidos: as paixões como fator preponderante 94

\section{A RECEITA TRIBUTÁRIA - EXTRAFISCALIDADE E INTERVENÇÃO NO} DOMÍNIO ECONÔMICO ............................................................................................. 101

3.1 Entradas e receitas - conceito, distinção e classificação ..................................... 101

3.1.1 Receitas ordinárias e extraordinárias ........................................................ 103

3.1.2 Receita originária e derivada .......................................................................... 104

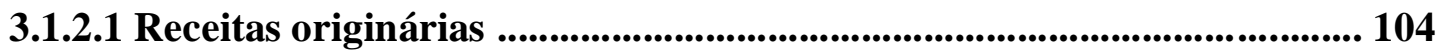

3.1.2.2 Receitas derivadas ........................................................................................ 106

3.2 Extrafiscalidade e intervenção no domínio econômico: oneração e

desoneração

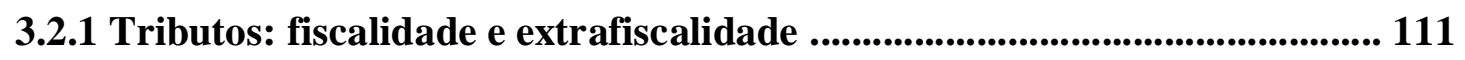

3.2.2 A extrafiscalidade como instrumento de intervenção .................................... 115

4 O GASTO PÚBLICO E O DOMÍNIO ECONÔMICO ..................................... 124

4.1 O gasto público como mecanismo de intervenção no domínio econômico ..... 124

4.1.1 Conceito e classificação das despesas públicas ................................................ 124

4.1.2 A despesa pública e seu caráter vinculativo .................................................. 127

4.1.3 A previsibilidade do gasto público como fator de indução e regulação da atividade econômica .......................................................................................... 133

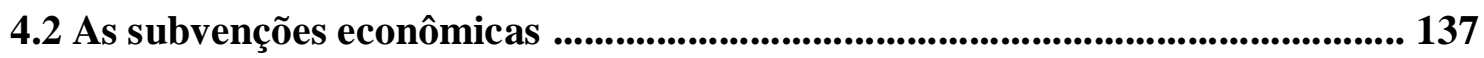


4.2.1 Conceito, distinções e características

4.2.2 Relevância e importância das subvenções econômicas 140

4.2.3 Os problemas decorrentes de uma política subvencionista e a necessidade de se empreender maior controle e fiscalização

5 DívidA PÚblica, CRÉdito PÚBLICO, ORÇAMENTO E INTERVENÇÃo NO DOMÍNIO ECONÔMICO ........................................................................................ 146

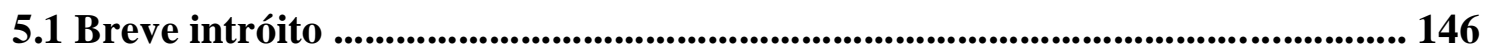

5.2 Conceito e elementos constitutivos do crédito: confiança, capital e tempo .... 151

5.3 Os empréstimos públicos e as receitas ordinárias ................................................. 154

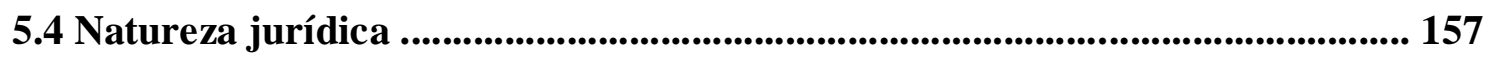

5.5 Classificações ........................................................................................................ 164

5.5.1 Dívida federal, estadual e municipal ..................................................... 166

5.5.2 Dívida pública externa e interna ............................................................... 167

5.5.3 Dívida flutuante e dívida fundada ou consolidada ................................... 169

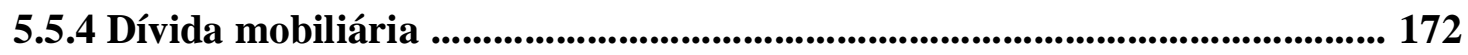

5.6 Histórico da dívida pública brasileira e os limites de endividamento ............. 174

5.6.1 Breve escorço histórico ............................................................................ 174

5.6.2 Requisitos e limites do endividamento público federal ............................. 180

5.7 A dívida pública e o domínio econômico ................................................................. 182

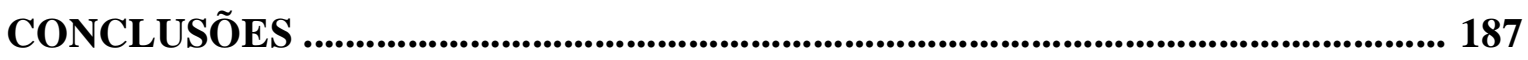

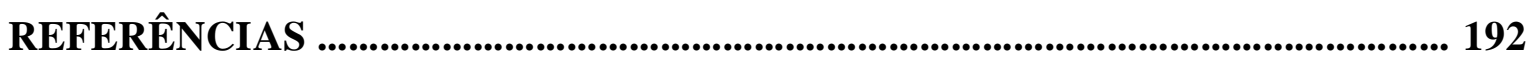




\section{INTRODUÇÃO}

Afirma-se, há tempos, que é impossível dissociar a atividade financeira do Estado da economia, da qual este se vale para obter e empregar recursos materiais necessários à realização de seu principal objetivo, qual seja, a satisfação do bem comum e a promoção da justiça social.

Esta dissertação tomará como ponto de partida o direito financeiro, o direito econômico e a teoria geral do estado, disciplina direcionada ao estudo de fenômenos como a origem, formação, estrutura, organização e funcionamento do Estado, até a análise de suas finalidades, não apenas sob a ótica do direito, mas, também, com o auxílio de outras ciências humanas, como a sociologia, a filosofia e a economia, para delinear o conteúdo, o alcance e a finalidade da peça orçamentária como instrumento de intervenção no domínio econômico, meio destinado à regulação e satisfação dos anseios da sociedade e dos objetivos do Estado.

Examinar-se-á a relação entre o Estado e a sociedade, especificamente no tocante ao exercício da atividade estatal na obtenção e emprego dos meios materiais e serviços para a satisfação das necessidades humanas, as quais impulsionam os indivíduos a agir na persecução de seus interesses e implicam, além do exercício da função de órgão político, monopolizador do poder, a criação e disponibilização crescente de serviços públicos e a regulação da atividade econômica.

Serão tratados alguns aspectos da peça orçamentária, especificamente sob o enfoque do exercício do poder soberano e, de modo pontual, os meios e os atos praticados pelo Estado que interferem direta e indiretamente na atividade econômica privada, seja na qualidade de agente regulador, em que exerce as funções de fiscalização, incentivo e planejamento, seja na qualidade de agente executor, em que apenas traça ditames a serem seguidos, estabelecendo normas a serem cumpridas.

O propósito desta pesquisa é contribuir para a compreensão jurídica de diversas questões atinentes ao orçamento público, bem como demonstrar que este constitui peça fundamental para o desempenho da atividade do Estado e verdadeiro instrumento de 
intervenção no domínio econômico, uma vez que por meio da receita e realização da despesa pública este se vale para influenciar - e até mesmo direcionar - a economia e seus agentes, denotando a necessidade de dotar seus atos de maior segurança jurídica, a fím de evitar e coibir abusos.

O presente trabalho tem, assim, por escopo examinar as diversas funções do Estado soberano, os poderes de que dispõe para cumprir e atender a seus objetivos, os instrumentos que estão ao seu alcance e os limites legais e econômicos, ainda que seja necessário abordar aspectos não jurídicos, para verificar se a peça orçamentária constitui, de fato, um instrumento válido e eficaz de intervenção do Estado na atividade econômica.

Para tanto, tomar-se-á como objeto de análise e estudo, o orçamento público da União, adotando-se uma relação macro do sistema financeiro, ainda que muitos dos aspectos abordados possam ser aplicados nos orçamentos dos demais entes federativos.

Este trabalho não contemplará a discussão do que se deve compreender por necessidades públicas, mas tão somente irá considerar a ideia de que estas correspondem às situações eleitas pelo povo em determinado momento histórico, cuja escolha se manifesta por meio da Constituição e de outras leis.

Em razão dos aspectos mencionados, o desenvolvimento desta pesquisa, de início, irá apontar alguns dos objetivos do Estado contemporâneo para, em seguida, proceder à análise de seus limites de atuação e do papel do orçamento público, oportunidade em que serão tratadas sua abrangência, características, finalidades e instrumentalidade. Por fim, serão explorados o conteúdo e o alcance dos atos de intervenção do Estado no domínio econômico e sua relação com os princípios, normas e regras que regem a técnica orçamentária, consagrados na Constituição Federal brasileira de 1988.

É importante destacar que essa abordagem não se destina a elaborar um histórico exaustivo acerca da constituição e origem do Estado, mas, sim, a identificar o que está além de sua definição jurídica, bem como a pontuar algumas questões subjetivas determinantes, ou não, para a tomada de decisões por aquele que exerce o munus publicum, as quais podem interferir direta ou indiretamente na atividade desempenhada pela iniciativa privada, seja para privilegiar ou prejudicar alguém, determinada atividade ou ramo. 
O estudo empregará os métodos dedutivo e indutivo, admitindo-se certos princípios gerais como exatos. O ponto de partida será a análise de casos específicos e concretos a fim de indicar suas circunstâncias e relações de causalidade determinantes para o exercício da atividade intervencionista do Estado, bem como sua correlação, dependência e previsibilidade orçamentária, sob a égide da Constituição Federal de 1988 e demais normas que regem todo o sistema, com o intuito de contribuir para a compreensão jurídica de diversas questões atinentes ao gerenciamento das despesas públicas, à satisfação dos interesses coletivos e aos mecanismos capazes de coibir abusos praticados pelos administradores brasileiros.

Saliente-se que o trabalho está estruturado em cinco capítulos, além da Introdução e das Conclusões.

Considerada essa orientação, far-se-á, inicialmente, um breve histórico sobre o atual modelo intervencionista e os propósitos do Estado contemporâneo, para então, no primeiro capítulo, dar conta da apreensão de noções oferecidas pelo Direito Econômico sobre o fenômeno da intervenção no domínio econômico, buscando sempre destacar o orçamento como o instrumento objeto de análise.

O segundo capítulo examinará o orçamento em específico, seu conteúdo, natureza jurídica e o objeto de cada uma das leis orçamentárias. O propósito, aqui, será deixar claro que o orçamento constitui um dos principais instrumentos de planejamento à disposição do Estado para o desígnio de seus objetivos.

O terceiro capítulo, observando o propósito de delimitação do objeto do presente estudo, discorrerá sobre as receitas orçamentárias, mais especificamente as receitas tributárias e sua utilização como instrumento de intervenção sobre o domínio econômico, investigando, assim, o papel da denominada extrafiscalidade no cenário econômico.

O quarto capítulo, seguindo nessa mesma linha de raciocínio, terá por objeto de análise o gasto público. Sua abordagem procurará demonstrar, com base no conceito e classificação das despesas públicas, de que forma e qual o papel que estas assumem perante o domínio econômico, como delas se vale o Estado para alcançar seus objetivos e intervir no domínio econômico.

O quinto e último capítulo tratará do crédito público, empréstimo público, endividamento e dívida pública, abordando sua natureza jurídica, características e 
classificações para, enfim, confrontar sua relevância com o papel que a dívida pública exerce sobre o domínio econômico, suas finalidades e implicações.

Por derradeiro, serão retomados os pontos principais para tecer considerações e ratificar as argumentações apresentadas durante o desenvolvimento do trabalho, indicando as conclusões alcançadas pela pesquisa. 


\section{O ESTADO INTERVENCIONISTA}

\subsection{Do "liberalismo" ao intervencionismo estatal e a ordem econômica}

Desde a transferência, pelo povo, do exercício do poder para um representante, dotado de força suficiente para impor determinados comportamentos e solucionar conflitos em busca do bom funcionamento da sociedade, com a constituição do que se denomina atualmente Estado, verifica-se sua intervenção na esfera de atividade do particular.

Observam-se, daí por diante, formas distintas de intervenção do Estado na sociedade e na economia.

De acordo com Michel Foucault, é no século XVII (1601-1700) que se tornou, de fato, pertinente na história das sociedades ocidentais o modelo de intervenção estatal destinado a propiciar um melhor viver e o bem-estar dos indivíduos. Tem como causa a relação entre a razão de Estado e o privilégio urbano, entre a polícia e o primado da mercadoria, tomando a governamentalidade do Estado significado "pela materialidade fina da existência e da coexistência humana, pela materialidade fina da troca e da circulação", passando o comércio a ser visto como o instrumento principal da força do Estado ${ }^{1}$.

Ainda que a história mostre o Estado sempre atuando no domínio econômico ${ }^{2}$, as atuais ideias intervencionistas de fato surgiram na classe intelectual antes da Primeira Guerra Mundial (1914-1918). No entanto, é em decorrência dessa Guerra Mundial e do progresso econômico despontado com a Revolução Francesa de $1789^{3}$ que muitos sugerem ser esse o marco de eclosão do Estado Intervencionista, o que comumente se denominou

\footnotetext{
${ }^{1}$ FOUCAULT, Michel. Segurança, território, população: curso dado no Collège de France (1977-1978). Tradução de Eduardo Brandão e revisão de Claudia Berliner. São Paulo: Martins Fontes, 2008. p. 456.

${ }^{2}$ A propósito, vale conferir a palestra proferida no plenário do Tribunal Regional Federal da $4^{\text {a }}$ Região. (FERREIRA FILHO, Manoel Gonçalves. A intervenção do estado no domínio econômico e a Constituição de 1988. Revista do Tribunal Regional Federal: 4를 Região, ano 24, n. 82, p. 61-74, 2013, passim).

${ }^{3}$ Em face de uma grave crise financeira, decorrente da participação na Guerra da Independência dos Estados Unidos da América, na Guerra dos Sete Anos e dos elevados custos da Corte de Luís XVI, instaurou-se na França um período de intensa agitação política e social que culminou na proclamação da Primeira República francesa (1792), na supressão de privilégios feudais, aristocráticos e religiosos e na eclosão de novos princípios: liberdade, igualdade e fraternidade.
} 
"economia de guerra", pois todo o planejamento econômico-financeiro de um Estado passa a girar em torno de suas necessidades militares.

A intervenção estatal passa a ser marcada pela necessidade dos Estados em auferir renda suficiente para manter seu poderio bélico e evitar a dependência ou submissão aos ditames de seu opositor.

Os fatos apontados remetem, ainda que inaceitáveis nos dias de hoje, às lições de Maquiavel ${ }^{4}$, em particular quando trata da conquista, da manutenção do poder e das consequências sofridas pelos Estados dominados como fundamento de sua teoria:

\begin{abstract}
Quando estes Estados conquistados estão acostumados a viver com suas leis e em liberdade, querendo, há três modos para mantê-los. O primeiro é aniquilá-los. O outro é residir neles. O terceiro é deixá-los viver com suas leis, retirando uma renda e criando internamente um governo de poucos que manterá o consenso. Tal governo, consciente do fato de existir pela vontade do príncipe, sabe que depende de sua benevolência e poder e tem todo o interesse em agir de modo a conservar a situação. O modo mais fácil de manter uma cidade livre é confiar o seu governo aos próprios cidadãos.
\end{abstract}

Motivado pela revolução do modo de pensar e diante de uma nova concepção das instituições públicas, referido modelo econômico, intervencionista, toma força no pósguerra, ou seja, em tempos de paz, quando então passa a representar o ideal de uma economia planificada e um modelo a ser seguido por vários Estados.

Esse modelo intervencionista contrapôs-se ao modelo comunista implantado na União Soviética e na Alemanha, que se mostrou incapaz de gerar o almejado bem-estar social e cujos problemas enfrentados devastaram suas economias. É emblemático, v.g., o ocorrido na extinta União Soviética, onde passaram a imperar a pobreza e a fome em massa, assim como na Alemanha, totalmente destruída, em que se via a devastação decorrente da hiperinflação e das indenizações de guerra.

Posteriormente, com o advento da denominada "Crise de 1929" ou "Grande Depressão", considerado o pior e mais longo período de recessão econômica do século $\mathrm{XX}$, verifica-se o avanço do modelo intervencionista do Estado em detrimento do Estado liberal.

\footnotetext{
${ }^{4}$ MAQUIAVEL, Nicolau. O príncipe. 22. reimpressão. Tradução de Maria Lucia Cumo. Rio de Janeiro: Paz e Terra, 1996. p. 29.
} 
Diante dos altos índices de desemprego, da grande queda do PIB de diversos países e da brusca depressão industrial, os Estados, de modo geral, veem-se obrigados a intervir para impulsionar a atividade econômica e recuperar os países das crises decorrentes do pós-Guerra.

No campo da macroeconomia despontam as ideias revolucionárias de John Maynard Keynes ${ }^{5}$, cujos ideais se fundam no estudo das medidas de intervenção do governo na economia, na busca pelo pleno emprego, no desenvolvimento econômico, na estabilização da moeda e na melhor distribuição da renda. O dirigismo estatal se coloca acima do protecionismo comercial, dando ênfase à Teoria Marxista, fundada na existência de uma sociedade de classes em que os interesses de seus membros se mostram antagônicos, opostos à realização do bem comum e à neutralização do Estado.

De acordo com André de Laubadère ${ }^{6}$, a crise econômica de 1929 constitui o grande fator circunstancial do intervencionismo. Passa-se a falar em economia dirigida e, a partir de 1930, nascem as primeiras intervenções econômicas do Estado, quando este assume o controle das importações e substitui a antiga política alfandegária impondo a utilização de licenças, a adoção de medidas restritivas no campo e a interferência nos transportes.

É ainda nesse período de entreguerras que surgem as sociedades de economia mista, oriundas da união de recursos públicos e privados, cuja fórmula até os dias atuais impera como verdadeiro instrumento de intervenção no domínio econômico. Veja-se:

\begin{abstract}
No respeitante à economia mista, constituída pela reunião de capitais públicos e de capitais privados no seio das sociedades mistas, o período de entre as duas guerras foi ainda mais importante pois foi então que esta fórmula teve início; de resto viria a conhecer seguidamente uma história em "dentes de serra", marcada pela alternância de períodos de favor e períodos de desfavor. Surgiu então um domínio como terreno de eleição da economia mista $[\ldots]^{7}$.
\end{abstract}

Em suma, com o fim da Primeira Guerra e antes do início da Segunda impôs-se a necessidade de reestruturação dos poderes do Estado, elevando o direito público sobre o

\footnotetext{
${ }^{5}$ KEYNES, John Maynard. Teoria geral do emprego, do juro e da moeda. Tradução de Manuel Resende. São Paulo: Saraiva, 2012. p. 85-95/145-147/221-229.

${ }^{6}$ LAUB ADÈRE, André de. Direito público económico. Traduzido por Maria Teresa Costa; revisto por Evaristo Mendes. Coimbra: Almedina, 1985. p. 40.

${ }^{7}$ Ibidem, p. 42.
} 
direito privado, em que o Poder Executivo passa a se sobrepor aos Poderes Legislativo e Judiciário, pois se mostra determinante a promoção da paz e do bem-estar social.

Encarregado de promover a reestruturação das nações em crise, os Estados, por intermédio do Poder Executivo e de seus governantes, passam a intervir diretamente no domínio econômico. Orientados pelo interesse geral, deixa de subsistir a errônea concepção de que Estado e sociedade existam separadamente, conforme aponta Eros Roberto Grau ${ }^{8}$ :

\begin{abstract}
Ao Estado, até o momento neoconcorrencial ou intervencionista - qualquer que seja o vocábulo ou expressão que se adote para designar a mudança de regime que marca, no sistema capitalista, a passagem do século XIX para o século XX estava atribuída, fundamentalmente, a função de produção do direito e segurança. Para referir, em largos traços, o regime anterior, poderíamos afirmar, singelamente, que não se admitia a interferência do Estado na "ordem natural" da economia, ainda que lhe incumbisse a defesa da propriedade. Essa concepção porta em si a pressuposição de que ambos, Estado e sociedade, existissem separadamente um do outro, o que não é correto.
\end{abstract}

Surge, assim, o Estado moderno com a incumbência de atuar no campo econômico, promover a formação e a preservação do modo de produção; garantir o direito de propriedade e a liberdade de contratar; proteger o sistema de mercado contra efeitos secundários autodestrutíveis; assegurar as premissas da produção dentro da economia global, como, v.g., educação, transporte, comunicações, além de outros bens indispensáveis ao bem-estar social ${ }^{9}$.

Verifica-se que os profundos abalos da ordem econômica, decorrentes, sobretudo, de guerras e crises econômicas - particularmente após a Primeira Guerra Mundial -, impulsionaram as Constituições à adoção de algumas características comuns. Consideradas parte do novo "constitucionalismo social", essas Constituições incluíram, em boa parte dos Estados europeus e ao lado dos tradicionais direitos individuais, os chamados direitos sociais ou direitos de prestação, os quais dependem de prestações diretas e indiretas do

\footnotetext{
${ }^{8}$ GRAU, Eros Roberto. A ordem econômica na Constituição de 1988. 14. ed. São Paulo: Malheiros, 2010. p. 16.

${ }_{9}$ Ibidem, p. 18.
} 
Estado para serem usufruídos pelos cidadãos ${ }^{10}$, bem como dispuseram sobre a estruturação e organização econômica desses Estados.

No campo econômico, deixa de subsistir o Estado Liberal, da livre iniciativa, "que se traduz no direito de qualquer cidadão exercer atividade econômica livre de qualquer restrição" "11, para dar espaço ao Estado Intervencionista, o qual participa da economia, "atua com o fito de se garantir o exercício racional das liberdades individuais"12 e cuja política "não visa ferir os postulados liberais, mas, tão somente, fazer com que o Estado coíba o exercício abusivo e pernicioso do liberalismo" $" 13$.

Para Vital Moreira, é introduzido "um novo modo do modo-de-ser das relações entre o económico e o jurídico-político, dentro da estrutura do estado moderno. Um novo modo-de-ser que exprime uma nova configuração da economia, da sociedade e do Estado, na sociedade capitalista contemporânea" ${ }^{\prime 14}$.

O modelo apontado, como assinala Gilberto Bercovici ${ }^{15}$, tem como precursora a Constituição alemã de 11 de agosto de 1919, frequentemente denominada "compromisso constitucional" ou "constituição programática" - esta também é conhecida simplesmente como Constituição de Weimar, a primeira carta a inserir, em uma secção especial, um conjunto de disposições relativas à economia ${ }^{16}$ que teve repercussão instantânea e profunda, tanto na Europa como fora dela, graças às inovações introduzidas, ao submeter o individualismo a serviço da coletividade e proteger os direitos individuais.

Tão logo promulgada, a Constituição de Weimar foi duramente criticada pelos juristas, que classificaram as normas constitucionais atinentes aos direitos e garantias como não jurídicas, assistemáticas e meras expressões políticas. Em suma, seus partidários, dentre os quais Carl Schmitt, defendiam os direitos fundamentais como seu conteúdo essencial, enquanto os opositores da República os viam como obstáculos desprezíveis, um resquício da burguesia liberal do século XIX, que deveria desaparecer ${ }^{17}$.

\footnotetext{
${ }^{10}$ BERCOVICI, Gilberto. Constituição econômica e desenvolvimento: uma leitura a partir da Constituição de 1988. São Paulo: Malheiros, 2005. p. 11; idem. Constituição e estado de exceção permanente: atualidade de Weimar. Rio de Janeiro: Azougue, 2004a. p. 25.

${ }^{11}$ FIGUEIREDO, Leonardo Vizeu. Lições de direito econômico. 3. ed. Rio de Janeiro: Forense, 2010. p. 43.

12 Ibidem, p. 45.

${ }^{13}$ Ibidem, loc. cit.

${ }^{14}$ MOREIRA, Vital. Economia e Constituição. 2. ed. Lisboa: Coimbra, 1979. p. 9.

${ }^{15}$ BERCOVICI, Gilberto. Op. cit., p. 27.

${ }^{16}$ Ibidem, p. 78.

${ }^{17}$ Ibidem, p. 27-30.
} 
Considerada uma das primeiras Constituições econômicas, dispunha de um capítulo específico denominado "A vida econômica" e, assim como as demais constituições econômicas do século XX, não pretendia receber a estrutura econômica existente, mas alterá-la, o que lhe rendeu os ares de Constituição inovadora por positivar as tarefas a serem realizadas pelo Estado e pela sociedade no âmbito econômico, bem como por estabelecer a busca de determinados objetivos que também foram inseridos no texto constitucional $^{18}$.

No Brasil, esta se instaura com a promulgação da Constituição de 16 de julho de 1934, a qual inaugura o que se intitulou por terceira grande época ${ }^{19}$ e fora marcada por crises, golpes de Estado, insurreição, impedimentos, renúncia e, até mesmo, suicídio de Presidente e queda de governos republicanos ${ }^{20}$.

Aliado ao desejo de regular todas as instâncias do corpo social, com a Constituição de 1934 o Estado brasileiro promoveu uma intervenção maciça na economia e, sob a influência da Constituição de Weimar, abrindo espaço para o tratamento da ordem econômica e social, contando, inclusive, com a reprodução do art. 151 da Constituição alemã em uma de suas disposições, a qual tratava da garantia da liberdade econômica apenas nos limites da "ordem econômica" e deveria "ser organizada conforme os princípios da justiça de modo a que possibilite a todos existência digna" ${ }^{21}$.

Além disso, a Constituição brasileira adotou uma nova estruturação para o federalismo nacional, o qual fora denominado cooperativo, de acordo com o art. 9ํ․ . No art. 10, fixou pela primeira vez a repartição das competências concorrentes e, nos arts. 140 e

\footnotetext{
${ }^{18}$ BERCOVICI, Gilberto. Constituição e estado de exceção permanente: atualidade de Weimar, p. 39.

${ }^{19}$ De acordo com Paulo Bonavides, a primeira época está vinculada ao modelo constitucional francês e inglês do século XIX - estendendo-se de 1822 até 1889 -, em que o texto proposto introduziu em dois artigos um conceito de constitucionalidade, mantido depois pela Constituição de 1824, a qual teria sido, salvo notícia em contrário, a única Constituição Imperial no mundo que explicitamente perfilhou a repartição tetradimensional de poderes, ou seja, trocou o modelo de Montesquieu pelo de Benjamin Constant, acrescentando o Poder Moderador aos Poderes Executivo, Legislativo e Judiciário. A segunda época representaria uma ruptura ao modelo anterior e estaria atada ao modelo norte-americano. O novo Estado constitucional converter-se-ia, com a Constituição de 24 de fevereiro de 1891, em um Estado com plenitude formal das instituições liberais, fundado, especialmente, no princípio republicano, na forma presidencial de governo, na forma federativa de Estado e no funcionamento de uma suprema corte, apta a decretar a inconstitucionalidade dos atos do poder. Por fim, a terceira época, que ainda hoje se vive, tem seu marco nos primeiros anos da década de 1930, com as Constituições de 1933-1934, na qual se percebe a presença de traços fundamentais presos ao constitucionalismo alemão do século XX. Para um estudo mais aprofundado, veja-se: BONAVIDES, Paulo. Curso de direito constitucional. 23. ed. São Paulo: Malheiros, 2008. p. 361-370; BONAVIDES, Paulo; ANDRADE, Antonio Paes de. História constitucional do Brasil. 5. ed. Rio de Janeiro: OAB, 2004 .

${ }^{20}$ BONAVIDES, Paulo. Op. cit., p. 366.

${ }^{21}$ MOREIRA, Vital. Economia e Constituição, p. 81.
} 
177, tratou da cooperação entre os Entes Federados, ao dispor sobre o combate às endemias e às secas nas regiões constantemente atingidas .

Após 1934, todas as Constituições brasileiras, exceto a de 1988, passaram a incluir um capítulo sobre a ordem econômica e social, para tratar da intervenção do Estado na economia e dos direitos trabalhistas.

A Constituição Federal de 1988, por sua vez, inovou ao incluir os direitos trabalhistas no capítulo que trata dos direitos sociais (arts. $6^{\circ}$ a 11 ) e inaugura o Título VII, especificamente para tratar da ordem econômica e financeira (arts. 170 a 192) ${ }^{22}$, denotando verdadeiro alargamento das obrigações do Estado, que passou a atuar com maior dirigismo diante da necessidade de desenvolver e repensar sua relação com o mercado.

Como adverte Paulo Bonavides, é sobre uma terceira faixa que a Constituição inova profundamente. É sobre ela que "paira, todavia, o mais aceso dos debates e a mais acre das controvérsias: as regras nacionalistas sobre a ordem econômica, invectivas de xenofobia e desatualização com os rumos que, até mesmo das economias do mundo socialista, os ventos do progresso fazem soprar" 23 .

Expressamente reconhecida como uma Constituição econômica, dotada de um título específico, conforme mencionado, a Lei Maior brasileira é integralmente direcionada para a transformação das estruturas sociais. Ao sistematizar os dispositivos atinentes à atuação do Estado no domínio econômico, ainda que não se restrinjam a este capítulo do texto constitucional ${ }^{24}$, o Estado passou a figurar como agente normativo e regulador da atividade econômica, em detrimento de uma suposta livre iniciativa, que nunca fora absoluta.

Como bem sintetiza José Afonso da Silva, "a atuação do Estado, assim, não é nada mais nada menos do que uma tentativa de pôr ordem na vida econômica e social, de arrumar a desordem que provinha do Liberalismo" ${ }^{25}$.

Resta demonstrado que o Estado, de um modo ou de outro, sempre interveio na economia e na sociedade. Com os propósitos de pôr-se em ordem na vida econômica e na

\footnotetext{
${ }^{22} \mathrm{Na}$ Constituição anterior, os direitos sociais, trabalhistas e econômico-financeiros eram tratados em um mesmo título (Da Ordem Econômica e Social).

${ }^{23}$ BONAVIDES, Paulo; ANDRADE, Antonio Paes de. História constitucional do Brasil. 8. ed. Brasília: OAB, 2006. p. 490.

${ }^{24}$ BERCOVICI, Gilberto. Constituição e Estado de exceção permanente: atualidade de Weimar, p. 30.

${ }^{25}$ SILVA, José Afonso da. Comentário contextual à Constituição. 6. ed. São Paulo: Malheiros, 2009. p. 705.
} 
social, o povo lhe dotou de força e poder suficiente para impor a realização de determinados comportamentos, os quais nem sempre se restringem aos limites legais e até mesmo morais. Em suma, e como se propõe demonstrar nesta dissertação, o Estado - ou aqueles que o governam - vale-se de outros instrumentos, como o orçamento público, para conduzir a sociedade e a economia.

\subsection{Campo de atuação privada e campo de atuação reservado à Administração} Pública: principais distinções

Conforme observado, a Constituição Federal brasileira atual, influenciada pela Constituição de Weimar, e também pela Constituição mexicana de 1917, diante das transformações históricas apontadas, acabou por alargar de maneira significativa as obrigações do Estado, que, com isso, deixa de figurar como mero agente normativo e regulador da atividade econômica e começa a participar e atuar diretamente na economia, em áreas até então reservadas unicamente ao desenvolvimento dos negócios privados.

O Estado, desde os primórdios do pensamento liberal, incumbia-se da produção dos bens coletivos - v.g., exército, polícia, iluminação pública -, mas, sobretudo depois da Primeira Guerra Mundial, passa a se responsabilizar diretamente pela prestação de determinados bens que, ainda que qualificados como "públicos" e "sociais", poderiam ser produzidos pela iniciativa privada e foram retirados do mercado, deixando a intervenção do Estado na economia de limitar-se à produção dos bens coletivos ${ }^{26}$.

Diante disso, surge a necessidade de se fazer a distinção entre esses campos de atuação, isto é, entre aquele atinente à iniciativa privada e o adstrito às atividades estatais, a fim de possibilitar a compreensão do que se deve entender por domínio econômico ou atividade econômica e, por conseguinte, tratar das formas de atuação do Estado em relação ao processo econômico.

\footnotetext{
${ }^{26}$ MONCADA, Luís S. Cabral de. Direito económico. 5. ed. revista e actualizada. Lisboa: Coimbra, 2007. p. 435-436.
} 
Para tanto, tomar-se-á como ponto de partida a análise do texto constitucional, em particular das normas de conteúdo econômico e social, e daquelas que tratam de modo específico das atividades econômicas, previstas, respectivamente, no art. 21, incs. XI e XII, e nos arts. 173, 174 e 175, a fim de que se possam traçar as principais diferenças entre os campos de atuação privado e aquele atribuído ao Poder Público.

A atividade econômica, oriunda do regime capitalista, como é o brasileiro, prosperou no regime da livre iniciativa, consistente em um direito fundamental enquanto exercido com o propósito de atender à realização da justiça social, da valorização do trabalho e do desenvolvimento nacional ${ }^{27}$.

A Constituição Federal contempla uma ordem econômica fundada na valorização do trabalho humano e na livre iniciativa, e tem como propósito assegurar a todos uma existência digna e em consonância com a justiça social (art. 170). Em razão disso, a Lei Maior brasileira estabelece que a exploração direta de atividade econômica pelo Estado só será permitida quando necessária aos imperativos da segurança nacional ou para atender a relevante interesse coletivo (art. 173).

O texto constitucional denota que à iniciativa privada é conferido o privilégio de atuar no plano da atividade econômica, cabendo ao Poder Público, como exceção, desenvolver apenas as atividades que a ordem pública expressamente lhe atribui, em respeito ao princípio da legalidade, o qual, de acordo com Celso Antônio Bandeira de Mello, resulta “da submissão do Estado à lei"28.

Extensão da teoria da soberania popular e da representação parlamentar, qualquer "atentado" à liberdade econômica e à propriedade somente poderia ser consumado por intermédio de uma lei. Assume, assim, o princípio da legalidade sua dupla face, como supremacia e reserva da lei, pois “corolário da separação dos poderes, importando exclusivamente a oposição de um limite à atuação do Estado"29.

\footnotetext{
${ }^{27}$ SILVA, José Afonso da. Curso de direito constitucional positivo. 19. ed. São Paulo: Malheiros, 2001. p. 779.

${ }^{28}$ MELLO, Celso Antônio Bandeira de. Curso de direito administrativo. 28. ed. São Paulo: Malheiros, 2011. p. 100.

${ }^{29}$ GRAU, Eros Roberto. O direito posto e o direito pressuposto. 8. ed. São Paulo: Malheiros, 2011. p. 171.
} 
O Estado, diante do princípio da legalidade, estaria proibido de fazer o que a Constituição ou as leis explicitamente não autorizam ${ }^{30}$ e só estará autorizado a desenvolver qualquer atividade econômica quando esta se mostrar necessária à manutenção da segurança nacional ou de relevante interesse coletivo ${ }^{31}$.

Ainda que as considerações apresentadas não sejam pacíficas na doutrina, Maria Sylvia Zanella di Pietro ${ }^{32}$, ao tratar das alterações introduzidas no Direito Administrativo após a Constituição de 1988, e em face da adoção dos princípios do Estado Democrático de Direito ou da inspiração do neoliberalismo e da globalização ${ }^{33}$, afirma ter havido, dentre outros, o alargamento do princípio da legalidade, o qual teria deixado de se restringir apenas à lei, para abranger, também, princípios e valores, e com isso impor maior limitação à discricionariedade da Administração Pública, sujeitando-a ainda mais ao controle judicial.

A propósito, Odete Medauar ${ }^{34}$ esclarece que na passagem do Estado Liberal para o Estado Constitucional as leis já não mais persistiam intactas, tendo deixado o princípio da legalidade de ser compreendido como mera vinculação positiva à lei formal para conter também preceitos valorativos e éticos, sujeitando a atividade administrativa à observância dos preceitos fundamentais insculpidos na Constituição, como verdadeiros vetores indicativos e interpretativos à realização da atividade administrativa.

Tem-se que, por um lado, o princípio da legalidade inflige à Administração a obrigatoriedade de adotar, em sua atuação, um procedimento conforme a lei, obrigação essa consistente na imposição de aplicá-las e na proibição de delas se desviar (vinculação à lei em sentido estrito) e, por outro, significa que a Administração não pode violar o primado e a reserva de lei (vinculação à lei em sentido amplo).

\footnotetext{
${ }^{30}$ A Constituição Federal brasileira (art. 21) indica de modo expresso alguns serviços que, obrigatoriamente, constituem serviços públicos, atribuindo ao poder público sua exploração, dentre os quais se destacam: o serviço postal e o correio aéreo nacional (inc. X); os serviços de telecomunicações (inc. XI); e a navegação aérea, aeroespacial e a infraestrutura portuária (inc. XII).

${ }^{31}$ FERREIRA FILHO, Manoel Gonçalves. Curso de direito constitucional. 38. ed. rev. e atual. São Paulo: Saraiva, 2012. p. 394-395.

${ }_{32}^{32}$ DI PIETRO, Maria Sylvia Zanella. Direito administrativo. 26. ed. São Paulo: Atlas, 2013. p. 27-29.

${ }^{33}$ A respeito da influência da globalização sobre o direito, em especial o Direito Administrativo, vejam-se SUNDFELD, Carlos Ari; VIEIRA, Oscar Vilhena. Direito global. São Paulo: Max Limond, 1999. p. 157168; e GUERRA, Sérgio. Discricionariedade administrativa - limitações da vinculação legalitária e propostas pós-positivistas. In: ARAGÃO, Alexandre Santos de; MARQUES NETO, Floriano de Azevedo (Coord.). Direito administrativo e seus novos paradigmas. Belo Horizonte: Fórum, 2008. p. 205-240.

${ }^{34}$ MEDAUAR, Odete. O direito administrativo em evolução. 2. ed. São Paulo: Revista dos Tribunais, 2003. p. 146.
} 
De todo modo, e ainda que a doutrina não compartilhe do mesmo entendimento no tocante à atual abrangência do princípio da legalidade, verifica-se que, em qualquer uma das hipóteses apontadas - segurança nacional ou relevante interesse coletivo -, nem todas as atividades conferidas pela Constituição ao Poder Público lhe são reservadas, ou, em outras palavras, nem todas lhe são atribuídas com exclusividade.

É o caso, v.g., da educação, da saúde e dos serviços de previdência e de assistência social, que constituem deveres do Estado (arts. 196, 199, caput, 205 e 209 da CF/1988), embora também possam ser exploradas pela iniciativa privada.

Distintas do serviço público, certas atividades privadas entregues à livre iniciativa, por força de lei, dependem de prévia autorização dos órgãos públicos (art. 170, parágrafo único, da CF/1988), ou seja, “de uma prévia manifestação administrativa, destinada a verificar, no exercício de 'polícia administrativa', se será desempenhada dentro das condições compatíveis com o interesse coletivo" 35 .

Logo, o campo de atuação conferido à iniciativa privada é constituído pelas atividades próprias dos particulares, as quais, por sua vez, dividem-se em duas categorias $^{36}$ : (i) aquelas conferidas expressamente aos indivíduos pela Constituição como um direito subjetivo, dentre as quais citem-se o exercício do trabalho, ofício ou profissão (art. 5ํㅜ XIII, da CF/1988) e a exploração de atividade econômica (art. 170, parágrafo único, da CF/1988); e (ii) aquelas que, não tendo sido atribuídas com exclusividade ao Estado, lhes são facultadas, como as atividades de educação e saúde (arts. 199, caput, e 209 da CF/1988), anteriormente mencionadas.

Excluem-se do campo privado, portanto, as atividades que, segundo a Constituição Federal, são reservadas exclusivamente ao Estado e por este devem obrigatoriamente ser prestadas, não podendo ser transferidas por concessão, permissão ou autorizaçã ${ }^{37}$.

Para muitos autores é com base na compreensão do que se entende por serviço público que se separa o campo de atuação do Estado do campo atribuído aos particulares, compondo este último o que se denomina atividade econômica ou, simplesmente, domínio econômico. No entanto, mostra-se difícil a tarefa de traçar uma distinção entre ambas e apresentar uma noção exata do que se possa compreender por serviço público, pois as

\footnotetext{
${ }^{35}$ MELLO, Celso Antônio Bandeira de. Curso de direito administrativo, p. 693.

${ }^{36}$ SUNDFELD, Carlos Ari. Fundamentos de direito público. 3. ed. São Paulo: Malheiros, 1997. p. 75.

${ }^{37}$ Trata-se das hipóteses de monopólio da União constantes do art. 177 da CF/1988.
} 
mudanças no modelo de Estado provocaram alterações significativas em sua definição em cada sociedade e em cada período, como assinala Hely Lopes Meirelles ${ }^{38}$ : "Realmente, o conceito de serviço público é variável e flutua ao sabor das necessidades e contingências políticas, econômicas, sociais e culturais de cada comunidade, em cada momento histórico, como acentuam os modernos publicistas".

Além disso, Dinorá Grotti ${ }^{39}$, dentre outros, cita como sendo Jean-Jacques Rousseau o primeiro a se valer da expressão "serviço público" para significar qualquer atividade estatal abrangendo dois aspectos, in verbis:

[...] de um lado, trata-se de atividades destinadas ao serviço público, isto é, ações através das quais se assegura aos cidadãos a satisfação de uma necessidade sentida coletivamente, sem que cada um tenha de atendê-la pessoalmente; de outro, concebe-se como uma atividade estatal que sucede ao serviço do Rei, porque se operou uma substituição na titularidade da soberania.

De fato, Rousseau assim emprega a expressão, tanto quanto adverte que "a partir do momento em que o serviço público deixa de ser a principal preocupação dos cidadãos e em que eles preferem servir-se do seu bolso a servir-se da sua pessoa, o Estado já está à beira da ruína" 40 .

Mas foi durante o movimento da primeira industrialização, compreendido pelo período entre o término do século XIX e o final do século XX, que surgiu a Teoria do Serviço Público, então desenvolvida pelo Conselho de Estado e pelo Tribunal de Conflitos Francês, cujas primeiras noções foram esboçadas por Maurice Hauriou ${ }^{41}$ e, posteriormente, lapidadas por Léon Duguit, para quem todo problema da atividade do Estado se resolvia por uma antítese: mandar ou servir ${ }^{42}$. Assim é que Gaston Jèze, discípulo de Duguit, manifestou-se:

La idea de servicio público se halla íntimamente vinculada con la del procedimiento de derecho público.

\footnotetext{
${ }^{38}$ MEIRELLES, Hely Lopes. Direito administrativo brasileiro. 28. ed. São Paulo: Malheiros, 2003. p. 319.

${ }^{39}$ GROTTI, Dinorá Adelaide Museti. Teoria dos serviços públicos e sua transformação. In: SUNDFELD, Carlos Ari. Direito administrativo e econômico. 3. tiragem. São Paulo: Malheiros, 2006. p. 40.

${ }^{40}$ ROUSSEAU, Jean-Jacques. Do contrato social. Tradução de Eduardo Brandão; organização e introdução de Maurice Cranston. São Paulo: Penguin Classics/Companhia das Letras, 2011. p. 149.

41 RIVERO, Jean. Hauriou et l'avènement de la notion de service public. In: MESTRE, Melanges. L'evolution du driot public: études en l'honneur d'Achilles Mestre. Paris: Sirey, 1956. p. 461 e ss..

${ }^{42}$ DUGUIT, Léon. Les transformations du droit public. Paris: A. Colin, 1913. p. X.
} 
Decir que, en determinada hipótesis, existe servicio público, equivale a afirmar que los agentes públicos, para dar satisfacción regular y continua a cierta categoría de necesidades de interés general, pueden aplicar los procedimientos del derecho público, es decir, un régimen jurídico especial, y que las leyes y reglamentos pueden modificar en cualquier momento la organización del servicio público, sin que pueda oponerse a ello ningún obstáculo insuperable de orden jurídico $^{43}$. (grifo do original)

Para Gaston Jèze ${ }^{44}$, a Administração Pública deve satisfazer uma série de necessidades de interesse geral, dentre as quais algumas devem ser satisfeitas de forma exclusiva e, outras, em conjunto com os particulares, denotando a existência de dois procedimentos para sua realização - o de direito privado e o de serviço público -, segundo os quais:

\begin{abstract}
El procedimiento del derecho privado supone, esencialmente, la igualdad de los intereses particulares en conflicto. Ningún interés privado, por legítimo y digno de estímulo que sea, puede prevalecer sobre otro interés privado, por más egoísta que fuese este último. [...].

Por lo contrario el procedimiento del derecho público tiene su fundamento en la idea de desigualdad de los intereses en conflicto: el interés público debe prevalecer sobre el interés privado. Éste es el principio dominante, y no es necesario que la ley se haya referido a él, expresamente, para tal o cual interés público. (grifo do original)
\end{abstract}

Diante da teoria desenvolvida pelo jurista francês em comento, duas noções de serviço público surgiram: uma ampla, indicando todo o conjunto de fins sociais a serem garantidos pela Administração Pública; e outra estrita, segundo a qual, o Estado deveria assumir, de forma direta ou controlada, a realização de certas necessidades sociais sob a veste de um regime exorbitante de direito comum.

Em suma, nessa época, a noção de serviço público detinha alguns contornos bastante definidos: um elemento subjetivo, caracterizado pelo fato de ter de ser prestado apenas pelo Estado; outro objetivo, pois tinha por objeto a satisfação de necessidades coletivas; e um terceiro elemento, formal, que o sujeitava a um regime jurídico exclusivamente de direito público.

${ }^{43}$ JÈZE, Gaston. Principios generales del derecho administrativo. Traduzido para o espanhol por Julio N. San Millán Almagro. Buenos Aires: Depalma, 1949. v. II, t. I, p. 4. Tradução da 3. ed. francesa: Les principes généraux du droit administratif.

${ }^{44}$ Ibidem, p. 5-6. 
Reconhecia-se a existência de um serviço público quando as autoridades de um país, em determinada época, decidiam satisfazer as necessidades de interesse geral valendo-se do sistema público ${ }^{45}$.

Nada distante da conclusão enunciada por Bandeira de Mello ${ }^{46}$, segundo o qual a noção de serviço público há de se compor, necessariamente, de dois substratos: um material, consistente na prestação de utilidade ou comodidade fruível singularmente pelos administrados e, outro, formal, que lhe confere justamente caráter de noção jurídica, consistente em um específico regime de Direito Público.

Ocorre que ao longo do tempo e inicialmente nos países europeus, o modelo de financiamento dos serviços públicos pelo orçamento do Estado se revelou impraticável. As despesas públicas aumentaram vertiginosamente e o Estado perde eficiência na prestação dos serviços públicos, deixando de funcionar o propósito redistributivo, o que impunha, especificamente na Europa, a revisão do "Estado Social", como se tem verificado desde a década de $1980^{47}$.

No Brasil, nas últimas décadas, teve início o que se intitulou "Reforma do Estado". Iniciada mais precisamente em meados da década de 1990, seus objetivos eram marcados pelos propósitos de reestruturação e reformulação da forma de intervenção do Estado no domínio econômico, os quais causaram reflexos diretos na noção de serviço público, então construído basicamente sob o contexto do Estado Social.

Com a adoção de diversas medidas visando à reformulação do aparelho estatal - a qual é marcada no plano constitucional pela introdução da Emenda Constitucional n ${ }^{\mathrm{o}}$ 19/1998 -, dentre as quais notadamente as que tinham por objetivo o encolhimento da máquina estatal, restou instituído um amplo programa de privatizações tendentes a atribuir à iniciativa privada a prestação de serviços públicos. O resultado foi o nascimento das agências reguladoras que ainda hoje detêm como principal incumbência fiscalizar as atividades deixadas a cargo do setor privado ${ }^{48}$.

\footnotetext{
45 JÈZE, Gaston. Principios generales del derecho administrativo, p. 19.

${ }^{46}$ MELLO, Celso Antônio Bandeira de. Curso de direito administrativo, p. 682.

${ }^{47}$ MONCADA, Luís S. Cabral de. Direito económico, p. 437.

${ }^{48}$ GROTTI, Dinorá Adelaide Museti. O serviço público e a Constituição Brasileira de 1988. São Paulo: Malheiros, 2003. p. 141.
} 
Além disso, tinha-se como propósito instituir a chamada "administração gerencial" $^{49}$, com a finalidade de atribuir maior eficiência na prestação dos serviços e, por consequência, obter resultados satisfatórios, inserindo na Administração Pública mecanismos da iniciativa privada ${ }^{50}$.

Esse conjunto de medidas afetou a concepção clássica de serviços públicos trazida do Direito francês, considerada importante, por um lado, por separar a competência da jurisdição administrativa da competência da justiça comum e, por outro, por servir como critério de definição do próprio Direito Administrativo ${ }^{51}$, conforme salientado.

Alexandre Aragão ${ }^{52}$ esclarece que a noção de serviço público sempre fora marcada por sucessivas crises, destacando-se, dentre elas, duas. A primeira, ocorrida em meados do século $\mathrm{XX}$, com o aumento da intervenção estatal na economia, em que se verifica o incremento da intensidade de intervenção regulatória sobre as atividades econômicas privadas e mediante o exercício direto, pelo Estado, de uma série de atividades econômicas, comerciais e industriais. A segunda, iniciada na década de 1980, em que, ao contrário da primeira, foi determinante para o avanço da esfera pública sobre a privada, com a devolução ao mercado de uma série de atividades que dele haviam sido retiradas.

De qualquer modo, e como bem aponta o autor ${ }^{53}$ precitado,

[...] o serviço público, ainda que viva momentos de expansão e de retração, não vai deixar de existir. Poderá variar a sua titularidade, seu objeto, seu regime jurídico, e até as formas de sua prestação, dando maior protagonismo aos operadores privados. Todavia, o substrato público do instituto sempre se manterá.

\footnotetext{
${ }^{49}$ De acordo com Luiz Carlos Bresser-Pereira, foi no Governo Fernando Henrique Cardoso, diante de um quadro desfavorável e negativo cuja origem deu-se no Governo Collor, que se iniciou a mencionada reforma gerencial ou reforma da gestão pública de 1995. Principal protagonista dessa reforma, coube a Bresser Pereira e sua equipe idealizá-la e implementá-la, tendo como causa central o aumento do tamanho do Estado e sua transformação em Estado democrático e social, que o obrigava a se tornar mais eficiente. É o que se pretendeu com a reforma constitucional efetivada com a edição da Emenda Constitucional n⿳ํㅡㄹ 19/1998, cuja grande parte das mudanças institucionais foram de caráter infraconstitucional (BRESSER-PEREIRA, Luiz Carlos. Burocracia pública e reforma gerencial. Revista do Serviço Público, Brasília, p. 29-48, ed. esp. de 2007).

${ }^{50}$ BERCOVICI, Gilberto. Constituição econômica e desenvolvimento: uma leitura a partir da Constituição de 1988 , p. 82.

${ }^{51}$ DI PIETRO, Maria Sylvia Zanella. Direito administrativo, p. 99-100.

${ }^{52}$ ARAGÃO, Alexandre Santos de. O serviço público e as suas crises. In: ARAGÃO, Alexandre Santos de; MARQUES NETO, Floriano de Azevedo (Coord.). Direito administrativo e seus novos paradigmas. Belo Horizonte: Fórum, 2008. p. 421-440.

${ }^{53}$ SARASOLA GORRITI, Silbia. La concesión de servicios públicos municipales: estudio especial de las potestades de intervención. Oñati: IVAP, 2003. p. 22-23.
} 
Diante das considerações tecidas e ainda que seja tarefa difícil condensar os elementos que identifiquem o conteúdo da expressão serviço público, mostra-se de relevância consignar alguns significados propostos pela doutrina atual, dentre os quais este estudo se coaduna com o sentido empregado por Celso Antônio Bandeira de Mello ${ }^{54}$, conforme colacionado a seguir:

\begin{abstract}
Serviço público é toda atividade de oferecimento de utilidade ou comodidade material destinada à satisfação da coletividade em geral, mas fruível singularmente pelos administrados, que o Estado assume como pertinente a seus deveres e presta por si mesmo ou por quem lhe faça as vezes, sob um regime de Direito Público - portanto, consagrador de prerrogativas de supremacia e de restrições especiais -, instituído em favor dos interesses definidos como públicos no sistema normativo.
\end{abstract}

Nessa mesma linha de raciocínio, Odete Medauar ${ }^{55}$ diz que serviço público está atrelado às atividades realizadas no âmbito das atribuições da Administração e, assim, inserido no Executivo, consistindo em uma atividade "prestacional, em que o poder público propicia algo necessário à vida coletiva, como, por exemplo, água, energia elétrica, transporte urbano", não se inserindo nesse conceito as atividades-meio, como, v.g., arrecadação de tributos, serviços de arquivo, limpeza e vigilância de repartições etc..

Hely Lopes Meirelles, por sua vez, entende serviço público como "todo aquele prestado pela Administração ou por seus delegados, sob normas e controles estatais, para satisfazer necessidades essenciais ou secundárias da coletividade ou simples conveniências do Estado" ${ }^{, 56}$.

Ainda, de acordo com ponderação de Luís S. Cabral de Moncada ${ }^{57}$ :

\begin{abstract}
Claro está que o serviço público é sempre um serviço de interesse geral, sendo este elemento essencial da respectiva noção. Apenas sucede que o serviço público pode ser prestado por entidades públicas e temos o serviço público em sentido orgânico ou subjectivo e por outras entidades autónomas e privadas e temos o serviço público em sentido funcional e objectivo.
\end{abstract}

\footnotetext{
${ }^{54}$ MELLO, Celso Antônio Bandeira de. Curso de direito administrativo, p. 679.

${ }^{55}$ MEDAUAR, Odete. Direito administrativo moderno. 16. ed. São Paulo: Revista dos Tribunais, 2012. p. 347.

56 Ibidem, p. 319.

${ }^{57}$ MONCADA, Luís S. Cabral de. Direito económico, p. 439.
} 
Eros $\mathrm{Grau}^{58}$ vai além e, valendo-se da expressão de maneira mais ampla, afirma que a noção de serviço público também há de ser construída sobre as ideias de coesão e de interdependência social. Diz ainda o autor, que essa atividade deve ser prestada à sociedade pelo Estado - ou por outra pessoa administrativa, direta ou indiretamente -, assumindo caráter existencial e constituindo uma atividade explícita ou supostamente definida pela Constituição como indispensável, “ou, em outros termos, [...] como serviço existencial relativamente à sociedade em determinado momento histórico" 59 .

Nota-se que os serviços públicos estão inseridos no campo de alçada do Estado, contrapondo-se ao o que a Constituição Federal chamou de "domínio econômico", ou seja, ao campo das atividades dos particulares, que, na definição de Lúcia Valle Figueiredo ${ }^{60}$, “compreende o conjunto de atividades desenvolvidas pela livre iniciativa. Portanto, constitui-se no centro onde gravita a possibilidade de se fazer riqueza, ou seja, a atividade econômica".

Com o propósito de melhor especificar o que se deve compreender sobre cada um dos termos jurídicos apresentados, esclarece Eros Grau que, do gênero atividade econômica, depreende-se duas espécies: (i) o serviço público; e (ii) a atividade econômica. $\mathrm{E}$, no que toca às atividades econômicas propriamente ditas (espécie), distinguem-se estas em atividades econômicas em sentido amplo e em sentido estrito ${ }^{61}$.

Nas palavras desse autor ${ }^{62}$ :

Por certo que, no art. 173 e seu $\S 1^{\circ}$, a expressão conota atividade econômica em sentido estrito. $\mathrm{O}$ art. 173, caput, enuncia as hipóteses nas quais é permitida ao Estado a exploração direta de atividade econômica. Trata-se, aqui, de atuação do Estado - isto é, da União, do Estado-membro e do Município - como agente econômico, em área da titularidade do setor privado. Insista-se em que atividade econômica em sentido amplo é território dividido em dois campos: o do serviço público e o da atividade econômica em sentido estrito. As hipóteses indicadas no art. 173 do texto constitucional são aquelas nas quais é permitida a atuação da União, dos Estados-membros e dos Municípios neste segundo campo.

\footnotetext{
${ }^{58}$ GRAU, Eros Roberto. A ordem econômica na Constituição de 1988, p. 134.

${ }^{59}$ Ibidem, p. 135.

${ }^{60}$ FIGUEIREDO, Lúcia Valle. Reflexões sobre a intervenção do estado no domínio econômico e as contribuições interventivas. In: MACHADO, Hugo de Brito (Coord.). As contribuições no sistema tributário brasileiro. São Paulo: Dialética / Fortaleza: Instituto Cearense de Estudos Tributários, 2003. p. 397.

${ }^{61}$ GRAU, Eros Roberto. Op. cit., p. 101-102.

${ }^{62}$ Ibidem, p. 103.
} 
Para Eros Grau, portanto, “o Estado não pratica intervenção quando presta serviço público ou regula a prestação de serviço público. Atua, no caso, em área de sua própria titularidade, na esfera pública" ${ }^{\circ 3}$.

Como assevera Bandeira de Mello ${ }^{64}$, a Constituição Federal estabeleceu "uma grande divisão: de um lado, atividades que são da alçada dos particulares - as econômicas; e, de outro, atividades que são de alçada do Estado, logo, implicitamente qualificadas como juridicamente não econômicas - os serviços públicos".

Extrai-se do exposto, que a noção de atividade econômica (em seu sentido estrito) é construída com base na eliminação das atividades atribuídas exclusivamente ao Estado (parcela do gênero atividade econômica), segundo a qual, o que não for serviço público (art. 175 da $\mathrm{CF} / 1988$ ) e estiver fora das demais preocupações estatais será atividade econômica ${ }^{65}$. Dito de outro modo:

\begin{abstract}
O que prevalece é a vontade soberana do Estado, qualificando o serviço como público ou de utilidade pública, para sua prestação direta ou indireta, pois serviços há que, por natureza, são privativos do Poder Público e só por seus órgãos devem ser executados, e outros são comuns ao Estado e aos particulares, podendo ser realizados por aqueles e estes. Daí essa gama infindável de serviços que ora estão exclusivamente com o Estado, ora com o Estado e particulares e ora unicamente com particulares ${ }^{66}$.
\end{abstract}

Em síntese, o campo de atuação conferido à iniciativa privada, ou seja, o domínio econômico, é constituído pelas atividades conferidas expressamente aos indivíduos pela Constituição como um direito subjetivo e por aquelas que, não tendo sido atribuídas com exclusividade ao Estado, lhes é facultada a exploração.

${ }^{63}$ GRAU, Eros Roberto. A ordem econômica na Constituição de 1988, p. 91.

${ }^{64}$ MELLO, Celso Antônio Bandeira de. Curso de direito administrativo, p. 801.

${ }^{65}$ NASCIMENTO, Tupinambá Miguel Castro do. Comentários à Constituição Federal: ordem econômica e financeira. Porto Alegre: Livraria do Advogado, 1997. p. 45.

${ }^{66}$ MEIRELLES, Hely Lopes. Direito administrativo brasileiro, p. 614. 


\subsection{Os objetivos da intervenção exercida pelo Estado sobre o domínio econômico}

Como já demonstrado neste estudo, o insucesso dos modelos intervencionistas social e socialista impôs ao Estado a necessidade de repensar as formas pelas quais poderia interferir no processo de geração de riquezas, tanto quanto na realização de políticas públicas de inclusão social e de repartição de rendas. Com isso, o Estado viu-se obrigado a abandonar a planificação econômica sem, todavia, voltar ao liberalismo econômico idealizado por Adam Smith.

Ainda que a Constituição brasileira (arts. 173 e 174) tenha assegurado à iniciativa privada a preferência pela exploração da atividade econômica, e que alguns propalem, como Hely Lopes Meirelles ${ }^{67}$, que não mais se admitiria nenhuma intervenção do Estado na economia, mas apenas sua atuação supletiva, verifica-se que o sistema capitalista nacional, como pontua Celso Bastos, encontra-se "temperado por graus diversos de intervenção do Estado" ${ }^{68}$.

A bem da verdade, e como já manifestado, o Estado nunca deixou de intervir no domínio econômico, ora o fazendo mais, ora menos, sendo certo que o texto constitucional vigente consagra uma economia de mercado descentralizada e sujeita à forte atuação do Estado $^{69}$.

Ao distinguir os campos de atuação pública e privada, pode-se dizer que ao intervir no domínio econômico, ou seja, no campo de atividade econômica em sentido estrito ${ }^{70}$, o Estado o faz para orientar a ação dos sujeitos econômicos, influenciando-os legislativa e administrativamente com o propósito de alcançar determinados fins.

De acordo com Fábio Nusdeo $^{71}$, duas seriam as motivações estatais para a intervenção: uma negativa e outra positiva. A primeira, dita negativa, decorreria de "uma ação não contra o mercado, mas, pelo contrário, em harmonia com ele, suprimindo-lhe as deficiências, sem lhe tolher as condições de funcionamento". A segunda, positiva, seria

\footnotetext{
${ }_{67}^{67}$ MEIRELLES, Hely Lopes. Direito administrativo brasileiro, p. 545/546.

68 BASTOS, Celso Ribeiro; MARTINS, Ives Gandra da Silva. Comentários à Constituição do Brasil: promulgada em 5 de outubro de 1988. São Paulo: Saraiva, 1988. v. 7, p. 12.

${ }^{69}$ MORAES, Alexandre de. Direito constitucional. 29. ed. São Paulo: Atlas, 2013. p. 832.

${ }^{70}$ MEIRELLES, Hely Lopes. Op. cit., p. 91-92.

${ }^{71}$ NUSDEO, Fábio. Curso de economia: introdução ao direito econômico. 6. ed. São Paulo: Revista dos Tribunais, 2010. p. 167-169.
} 
oriunda da "ordem decorrente da colocação, agora sim, consciente, de objetivos da política econômica no seu desempenho".

Na motivação negativa protege-se a livre iniciativa e as atividades econômicas desempenhadas pelos particulares, cabendo ao Estado tão somente corrigir distorções, ao passo que, na segunda, o Estado busca estabelecer objetivos para o mercado, ações diretivas e indutivas aos particulares para que esse mercado se aproxime ao máximo daquele desejado pelo Estado.

Corporificado e instrumentalizado pelo ordenamento jurídico, compete ao Estado atuar de acordo com os limites e parâmetros definidos na Constituição brasileira. A propósito, Celso Bastos ${ }^{72}$ explica que "o direito é essencial, necessário e inevitável ao Estado, pois é ele o conteúdo mínimo garantidor de sua essência”.

O poder que o Estado detém, de orientar e regular as relações econômicas, é determinado pelo texto constitucional e com o objetivo de atingir os fins almejados pela sociedade, dentre os quais, aqueles estabelecidos no preâmbulo e nos arts. $3^{\circ}$ e 170 , dentre outros, da Constituição Federal, e sobre os quais não compete, neste trabalho, tecer mais considerações.

Por isso se disse antes que o Estado intervencionista brasileiro passou a participar da economia e a atuar com a finalidade de garantir o exercício racional das liberdades individuais com o aparente propósito de coibir abusos, ainda que o texto constitucional (art. 170) tenha assegurado a todos o livre exercício de qualquer atividade econômica.

Sua transformação deu-se quando as ordens econômicas precedentes começam a instrumentar a implementação de políticas públicas, ou seja, "no instante em que a ordem econômica - parcela da ordem jurídica -, já instalada no nível constitucional, passa a predicar o aprimoramento da ordem econômica (mundo do ser), visando a sua preservação"73.

Como afirma Fernando Facury $\mathrm{Scaff}^{74}$, o Estado, ao intervir no domínio econômico, cumpre não apenas o papel socializante, mas, ao contrário, também:

\footnotetext{
${ }^{72}$ BASTOS, Celso Ribeiro. Curso de direito constitucional. 22. ed. rev. e atual. por Samantha Meyer-Pflug. São Paulo: Malheiros, 2010. p. 60.

${ }^{73}$ GRAU, Eros Roberto. A ordem econômica na Constituição de 1988, p. 72.

${ }^{74}$ SCAFF, Fernando Facury. Responsabilidade civil do estado intervencionista. 2. ed. São Paulo: Renovar, 2001. p. 91
} 
[...] o papel de mitigar os conflitos do Estado Liberal, através da atenuação de suas características - a liberdade contratual e a propriedade privada dos meios de produção -, a fim de que haja separação entre os trabalhadores e os meios de produção.

Pode-se dizer, com isso, que o Estado tem de intervir na economia não apenas para proteger os meios de produção - obrigação atribuída por muitos à classe dominante -, mas, também, para proteger a sociedade dos impactos destrutivos do capitalismo que, sujeito a períodos de recessão ou depressivos, deve procurar minimizá-los, mesmo naquelas situações em que seja impossível evitá-los.

Considerados os propósitos mencionados, o Estado se faz presente na atividade econômica de duas formas: (i) como agente econômico e (ii) como agente normativo e regulador da economia. Intervém, assim, na economia, porque há interesse privado, não diretamente na assunção daquela atividade, mas de que sua efetivação seja levada a termo pelo Estado ${ }^{75}$.

Ao exercer o poder de intervir no domínio econômico, a Constituição Federal brasileira (art. 174) determina que o Estado, na qualidade de agente normativo e regulador da atividade econômica, assim o faça na forma e nos limites legais, mas também com o propósito de realizar as funções de fiscalização, incentivo e planejamento, sendo este último determinante (obrigatório) para o setor público e indicativo para o setor privado.

A interferência do Estado no domínio econômico deve ser feita, portanto, com respeito aos ditames legais e tão somente com o propósito de normatizar e regular a atividade econômica, fiscalizando-a e, principalmente, incentivando sua realização a fim de propiciar o desenvolvimento do país, não podendo impor aos particulares "nem mesmo o atendimento às diretrizes ou intenções pretendidas, mas apenas incentivar, atrair os particulares, mediante planejamento indicativo"76.

\footnotetext{
${ }^{75}$ SCAFF, Fernando Facury. Responsabilidade civil do estado intervencionista, p. 97.

${ }^{76}$ MELLO, Celso Antônio Bandeira de. Curso de direito administrativo, p. 804.
} 


\subsection{Modos de intervenção}

Demonstradas as razões que impulsionaram os Estados a intervirem na economia, torna-se necessário elencar os principais modos de intervenção sobre o domínio econômico, ainda que não haja unanimidade na doutrina sobre a adoção de um critério específico.

Verificou-se, neste trabalho, que os serviços públicos constituem uma atividade explícita definida na Constituição Federal brasileira, existencial e indispensável à sociedade, inserida no campo de atuação do Estado $^{77}$. Assim, quando os realiza não há, portanto, que se falar em intervenção, pois o Estado atua em área de sua própria titularidade, ou seja, na esfera pública ${ }^{78}$.

Em face da variedade de propostas de classificações, e diante das distinções traçadas entre atividade econômica em sentido amplo e em sentido estrito, concentrando-se nesta última o objeto do presente estudo, procurar-se-á sintetizar as mais citadas tanto pela doutrina nacional como pela estrangeira. Em seguida, adotar-se-á um critério específico com o propósito de, posteriormente, identificar qual é efetivamente o papel que o orçamento público assume perante o domínio econômico.

A propósito, como demonstrado por Genaro Carrió, as classificações "no son ni verdaderas ni falsas, son serviciales o inútiles; sus vantajas o desventajas están supeditadas al interés que guía e quien las formula",79.

A despeito de todas as classificações se mostrarem parecidas ou similares, para que se possa operacionalizar o presente trabalho faz-se necessário tratar de ao menos uma delas, em razão de sua imprescindibilidade "para presentar un campo de conocimiento de una manera más fácilmente comprensible o más rica en consecuencias prácticas deseables" $" 80$.

\footnotetext{
${ }^{77}$ SILVA, José Afonso da. Curso de direito constitucional positivo, p. 779.

${ }^{78}$ GRAU, Eros Roberto. A ordem econômica na Constituição de 1988, p. 91.

${ }^{79}$ CARRIÓ, Genaro. Notas sobre derecho y lenguaje. 4. ed. Buenos Aires: Abeledo-Perrot, 1990. p. 99.

${ }^{80}$ Ibidem, p. 99.
} 


\subsubsection{Classificações propostas pela doutrina}

De início, recorre-se aos ensinamentos doutrinários de Bandeira de Mello ${ }^{81}$, segundo o qual, a interferência do Estado na ordem econômica pode ocorrer de três modos: (i) por meio de seu "poder de polícia", ou seja, na qualidade de agente normativo, regulador e fiscalizador da atividade econômica, em que o planejamento concebido constitui mera indicação para o setor particular e é determinante para o setor público (art. 174 da CF/1988); (ii) pelo exercício direto da atividade econômica, o que somente deve-se dar excepcionalmente e mediante a criação de pessoa específica para tal fim; e (c) por intermédio de incentivos concedidos à iniciativa privada (art. 174 da CF/1988), sejam eles fiscais ou financeiros.

Maria Sylvia Zanella di Pietro $^{82}$, nesse mesmo sentido, porém de forma mais objetiva, distingue os modos de intervenção em (i) direta, a qual consiste na atuação direta do Estado no domínio econômico, por meio, geralmente, das empresas estatais; e (ii) indireta, assim compreendida em face das atividades de regulamentação e fiscalização da atividade econômica privada.

De modo amplo, ao considerar que o Estado reconhece e assegura a propriedade privada e a liberdade de empresa de forma condicionada ao bem-estar coletivo, Hely Lopes Meirelles ${ }^{83}$ propõe uma classificação atrelada à atuação supletiva do Estado, a qual só se justifica como exceção à liberdade individual e desde que autorizada pela Constituição, destacando como principais meios de atuação na ordem econômica: (i) o monopólio; (ii) a repressão ao abuso do poder econômico; (iii) o controle do abastecimento; (iv) o tabelamento de preços; e (v) a criação de empresas estatais.

O autor em comento distingue duas formas de intervenção do Estado na atividade econômica: (i) no domínio econômico, a qual incide na atividade lucrativa da empresa e recai sobre o produto do trabalho humano, atribuindo-lhe um aspecto dinâmico, que, por sua vez, constitui objeto de estudo do Direito Econômico; e (ii) na propriedade privada, apresentada na forma estática, pois recai sobre os bens localizados no território do Estado e constitui matéria afeta ao Direito Econômico.

\footnotetext{
${ }^{81}$ MELLO, Celso Antônio Bandeira de. Curso de direito administrativo, p. 802.

${ }^{82}$ DI PIETRO, Maria Sylvia Zanella. Direito administrativo, p. 56-57.

${ }^{83}$ MEIRELLES, Hely Lopes. Direito administrativo brasileiro, p. 614.
} 
Em termos constitucionais, Luís Roberto Barroso ${ }^{84}$ classifica a intervenção do Estado no domínio econômico por meio de três mecanismos: (i) a disciplina; (ii) o fomento; e (iii) a atuação direta, em que, respectiva e sinteticamente, atua como agente normativo e regulador, exercendo a função de fiscalização prevista no art. 174 da CF/1988; apoia a iniciativa privada e estimula (ou desestimula) determinados comportamentos e, por fim, assume diretamente o papel de produtor ou prestador de bens ou serviços.

Ainda na seara constitucional, José Afonso da Silva distingue a atuação estatal em duas modalidades: (i) a participação; e (ii) a intervenção. $\mathrm{O}$ autor ${ }^{85}$ toma esta última em seu sentido restrito, segundo o qual:

\begin{abstract}
A primeira com base nos arts. 173 a 177, caracterizando o Estado administrador de atividades econômicas; a segunda fundada no art. 174, em que o Estado aparece como agente normativo e regulador da atividade econômica, que compreende as funções de fiscalização, incentivo e planejamento, caracterizando o Estado regulador, o Estado promotor e o Estado planejador da atividade econômica. (grifo do original)
\end{abstract}

Eros $\mathrm{Grau}^{86}$, por sua vez, prefere distinguir a presença do Estado no sistema econômico em três modalidades: (i) intervenção por absorção ou participação; (i) intervenção por direção; e (iii) intervenção por indução.

Com isso, tem-se que, na primeira modalidade, a intervenção dar-se-ia no domínio econômico em que o Estado atua como se fosse um agente econômico, assumindo ou participando na gestão ou controle do capital de uma unidade econômica que detenha o controle patrimonial dos meios de produção e de troca.

Ao realizar a intervenção por absorção, "o Estado assume integralmente o controle dos meios de produção e/ou troca em determinado setor da atividade econômica em sentido estrito; atua em regime de monopólio", ao passo que, na intervenção por participação, "assume o controle de parcela dos meios de produção e/ou troca em determinado setor da atividade econômica em sentido estrito; atua em regime de

\footnotetext{
${ }^{84}$ BARROSO, Luís Roberto. Modalidades de intervenção do Estado na ordem econômica. Regime jurídico das sociedades de economia mista. Inocorrência de abuso de poder. In: constitucional. Rio de Janeiro: Renovar, 2001. p. 395.

${ }^{85}$ SILVA, José Afonso da. Curso de direito constitucional positivo, p. 785.

${ }^{86}$ GRAU, Eros Roberto. A ordem econômica na Constituição de 1988, p. 146 e ss.. Temas de direito
} 
competição com empresas privadas que permanecem a exercitar suas atividades nesse mesmo setor" 87 .

Em ambas as modalidades - intervenção por absorção e intervenção por participação -, o Estado ou exerce diretamente a atividade econômica, em regime de monopólio estatal, legal ou de fato, ou o faz por intermédio de uma entidade criada para tanto, cuja empresa estatal misturar-se-á com as demais, sem perder, contudo, a sua capacidade de influência ${ }^{88}$.

Nas duas outras modalidades, ou subespécies - intervenção por direção e intervenção por indução -, verificar-se-ia a intervenção sobre o domínio econômico, na qual o Estado intervém sobre o campo de atividade econômica em sentido estrito na qualidade de regulador de determinada atividade, fazendo-o, assim como o próprio nome sugere, por direção ou por indução.

Ao fazê-lo por direção, o Estado pressiona a economia valendo-se de mecanismos e normas de comportamento compulsório que atingem diretamente os sujeitos da atividade econômica. Nesse tipo de intervenção permite-se tão somente o comportamento previsto na norma, a qual, descumprida, acarretará determinada sanção jurídica, como, v.g., a imposição de pagamento de multa.

Fábio Nusdeo propõe uma classificação mais política e econômica do que jurídica, ao enumerar as formas de intervenção do Estado no domínio econômico de acordo com o instrumento público econômico utilizado, intervenção essa que seria feita mediante: (i) instrumentos de finanças públicas; (ii) instrumentos monetários e creditícios; (iii) instrumentos cambiais; (iv) instrumentos de controle direto; e (v) adaptação institucional.

De acordo com a classificação proposta pelo referido autor, os três primeiros instrumentos, identificados pelos itens (i), (ii) e (iii), correspondem a uma ação eminentemente indireta da política econômica, pois, mediante estímulos ou punições de caráter fiscal, monetário e cambial, o Estado intervém ou influencia o comportamento do $\operatorname{mercado}^{89}$.

\footnotetext{
${ }^{87}$ GRAU, Eros Roberto. A ordem econômica na Constituição de 1988, p. 147.

${ }^{88}$ NUSDEO, Fábio. Curso de economia: introdução ao direito econômico, p. 197.

${ }^{89}$ Ibidem, p. 194-195.
} 
$\mathrm{O}$ item (iv), instrumentos de controle direto, destina-se a determinar certas variáveis do sistema econômico, que ocorrerão, dentre outras, com a fixação de preços e de salários, o contingenciamento do comércio exterior, o estabelecimento de cotas de produção, o racionamento, a determinação da taxa cambial etc. ${ }^{90}$.

Por fim, o item (v), adaptação institucional, consistiria em um tipo de ação propedêutica às demais, pois se dá mediante a criação de uma legislação adequada e de órgãos e instituições destinadas a legitimar a utilização de todos os outros instrumentos ${ }^{91}$ mencionados.

Na doutrina comparada, com merecido destaque ao critério proposto pelo autor lusitano Luís S. Cabral de Moncada ${ }^{92}$, as intervenções do Estado no domínio econômico são classificadas: (i) quanto a sua abrangência - intervenções globais, setoriais e pontuais (avulsas); (ii) quanto aos seus efeitos - intervenções imediatas e mediatas; (iii) quanto à manifestação de vontade - intervenções unilaterais e bilaterais; e (iv) quanto à atuação do Estado - intervenções diretas e indiretas.

De modo sintético, as intervenções globais distinguem-se das intervenções setoriais pelo fato de estarem relacionadas com a economia e de se verificarem quando o Estado adota normas gerais de fixação de margem de comercialização ou encorajamento do investimento global, ao passo que as setoriais se restringem à adoção de medidas destinadas a desenvolver um setor específico da economia, como o turismo, a agricultura, a siderurgia etc..

Na hipótese de o Estado intervir diretamente na economia, perseguindo objetivos especificamente econômicos em que exerce seu poder de polícia ou adota medidas de fomento à economia, estar-se-á diante do modo de intervenção imediata. Se, todavia, as medidas adotadas não têm apenas objetivos econômicos, mas repercutem na economia, como, v.g., nos casos de adoção de medidas de política fiscal, realização de operações de open market, definição de certos regimes jurídicos etc., tratar-se-á de intervenção mediata, sobre a economia e não na economia ${ }^{93}$.

\footnotetext{
${ }^{90}$ NUSDEO, Fábio. Curso de economia: introdução ao direito econômico, p. 195.

${ }^{91}$ Ibidem, loc. cit..

${ }^{92}$ MONCADA, Luís S. Cabral de. Direito económico, p. 41-47.

${ }^{93}$ Ibidem, p. 46.
} 
As intervenções unilaterais, por sua vez, consistem na proibição ou autorização de determinadas atividades e, em geral, são impostas por meio de regulamentos e atos administrativos. Essa modalidade de intervenção se opõe às intervenções bilaterais, que conformam intervenções estatais por via contratual ${ }^{94}$, ou seja, formas convencionais do exercício da autoridade que dependem da prévia e espontânea adesão do particular ${ }^{95}$. Para exemplificar, Luís S. Cabral de Moncada cita, dentre outros, (i) a oferta pelos poderes públicos de certas vantagens fiscais ou creditícias, concedidas em troca da execução por determinadas empresas privadas de determinada política de investimento; e (ii) a assinatura de contratos-programa, contratos de desenvolvimento, contratos de viabilização, contratos de investimento estrangeiro etc..

Esclarece ainda referido autor, que a intervenção indireta no direito econômico se dá quando o Estado - por si ou por interposta pessoa - não é o titular efetivo da exploração econômica, pois, caso contrário, a intervenção será direta, isto é, quando o Estado ou outra entidade pública seja o titular real da exploração da atividade econômica.

Por fim, na intervenção indireta o Estado age dirigindo ou controlando as atividades econômicas privadas na qualidade de agente fiscalizador (função de polícia) ou de estímulo (função de fomento), de modo a atender aos interesses públicos. Na intervenção direta, o Estado assume o papel de agente produtivo, criando empresas públicas ou controlando sociedades econômicas por meio das quais atua e intervém no processo de produção e distribuição, a qual se aplica na regulamentação do mercado, em que se dá a assunção total ou parcial de determinadas atividades ${ }^{96}$.

A doutrina francesa, com merecido destaque para a obra de André de Laubadère ${ }^{97}$, também se vale desse mesmo critério de classificação, proposto por Luís S. Cabral de Moncada.

\footnotetext{
${ }^{94}$ É oportuno observar que o autor se refere ao termo "contrato" de forma genérica, pois bem adverte que "não significa que todos estes instrumentos sejam, sob o ponto de vista da teoria jurídica, autênticos contratos". Afinal, ainda hoje, remanescem controvérsias na doutrina a respeito dos chamados "contratos administrativos", havendo, de acordo com Maria Sylvia Zanella di Pietro, ao menos três correntes: (i) a que nega a existência do contrato administrativo; (ii) a que afirma que todo contrato firmado pela Administração Pública é um contrato administrativo; e (iii) a que aceita a existência dos contratos administrativos como espécie do gênero contrato, com regime jurídico de Direito Público (DI PIETRO, Maria Sylvia Zanella. Direito administrativo, p. 260-262).

${ }^{95}$ MONCADA, Luís S. Cabral de. Direito económico, p. 42-43.

${ }^{96}$ Ibidem, p. 45.

${ }^{97}$ LAUB ADĖRE, André de. Direito público económico, p. 29 e ss.
} 
Como é possível notar, diversas são as classificações propostas, dando origem a inúmeras facetas. Alguns doutrinadores simplesmente distinguem a presença do Estado no domínio econômico em direta e indireta, ao passo que outros se limitam a propor uma releitura do texto constitucional e outros, ainda, preferem ir mais a fundo, ao apresentar subespécies e diferenciá-las quanto a sua abrangência e efeitos.

\subsubsection{Classificação adotada}

As inúmeras classificações apontadas demonstram que há uma grande diversidade dos modos de intervenção do Estado na economia e, mais especificamente, no domínio econômico, e que elas nem sempre se distinguem ou são apresentadas de maneira clara.

Por isso, a dificuldade em eleger uma delas em específico, ainda que se note, nos próximos capítulos, que, de certa maneira, todas as classificações propostas guardam relação direta ou indireta com o objeto do presente estudo. Em outras palavras, ao tratar das receitas, despesas e crédito público, a percepção de que todas elas possuem correlação com o orçamento público e o poder de impactar não apenas a economia de modo geral, mas na atividade desenvolvida pelo particular, seja para restringi-las, seja para fomentá-las, dar-se-á intuitivamente, assim como seus reflexos na sociedade.

Ao tomar-se em conta referidos fatores e tendo-se como caráter distintivo o objeto desta dissertação, remanescerão dúvidas não mais acerca da instrumentalidade do orçamento público, mas no que concerne à sua efetividade, qualidade e eficiência em seu emprego como instrumento de intervenção no domínio econômico. Afinal, procura-se avaliar se o Estado, aqueles que o administram e a própria iniciativa privada têm a clareza de sua importância e dos limites a serem respeitados.

Ademais, e embora a vida econômica seja regida por princípios naturais que não devem ser embaraçados pelo Estado - prevalência da iniciativa privada no plano da atividade econômica (art. 173 da CF/1988) -, também, faz-se necessário reprimir abusos e, com isso, intervir com o propósito de regulamentar determinadas atividades (art. 174 da $\mathrm{CF} / 1988$ ) ou espaldar a iniciativa particular fraca ou insuficiente, tendo por finalidade 
alcançar os objetivos delimitados na Constituição brasileira, os quais se traduzem nos anseios da sociedade.

Persegue-se, portanto, uma classificação que aponte para essas características, melhor dizendo, que seja capaz de demonstrar a relevância e importância do orçamento público também para a iniciativa privada e a necessidade de cobrar mais daqueles que detêm o munus publico de cumpri-lo fielmente.

Essa assertiva justifica-se em razão de, afinal, também ser por meio dos mecanismos ou ferramentas que o orçamento dispõe que o Estado se insere no domínio econômico privado com a finalidade de produzir resultados macro ou microeconômicos, diversos daqueles que adviriam caso não houvesse a intervenção, pois, ao praticá-la, persegue a alteração de parâmetros comportamentais originários do mercado no qual intervém, seja de forma promocional, restritiva ou repressiva ${ }^{98}$.

Logo, diante de todas as classificações anteriormente descritas, procura-se uma que seja capaz de demonstrar, de um lado, sua amplitude ou alcance e, de outro, os efeitos que a intervenção do Estado possa produzir - ou que se espera que produza - no domínio econômico.

Também eleito o orçamento público como o instrumento público utilizado para movimentar o domínio econômico e sem nenhum propósito de inovar, pois não existem classificações certas ou erradas, mas úteis ou inúteis, como adverte Genaro Carrióo ${ }^{99}$, sugere-se classificar as intervenções do Estado no domínio econômico em (i) intervenção por direção e (ii) intervenção por indução ou de fomento, bem como distingui-las em gerais, setoriais ou pontuais.

$\mathrm{Na}$ intervenção por direção, as medidas adotadas no orçamento terão como propósito atender às finalidades da lei, orientando ou restringindo a atividade econômica desempenhada por empresas públicas ou privadas, agindo o Estado de forma direta ou indireta, ou seja, explorando diretamente a atividade econômica por meio do monopólio ou com a criação de empresas públicas ou mistas; ou adotando medidas regulatórias ou fiscalizatórias, no exercício regular de seu poder de polícia. É o que se verifica, v.g.,

${ }^{98}$ MOREIRA, Egon Bockmann. O direito administrativo contemporâneo e a intervenção do Estado no domínio econômico. In: WAGNER JUNIOR, Luiz Guilherme da Costa (Coord.). Direito público: estudos em homenagem ao professor Adilson de Abreu Dallari. Belo Horizonte: Del Rey, 2004. p. 257-282.

${ }^{99}$ CARRIÓ, Genaro. Notas sobre derecho y lenguaje, p. 99. 
quando o Estado se vale das receitas públicas tributárias para dirigir ou regular determinados comportamentos, aumentando ou reduzindo a carga tributária.

Já na intervenção por indução ou de fomento, o Estado, por meio do orçamento público, promove o desenvolvimento da economia, favorece a iniciativa privada criando estímulos ou incentivos que forcem os agentes a adotar determinadas condutas impossíveis de serem implementadas, caso não existisse a intervenção estatal.

Essas condutas se verificam, principalmente, quando o Estado prevê a concessão de benefícios fiscais, a contração de dívidas com o propósito de realizar investimentos públicos, a abertura de linhas de crédito ao setor privado etc..

Em face da divisão estabelecida e dos propósitos a serem demonstrados com o presente trabalho, torna-se necessário tratar da amplitude ou alcance dos efeitos das intervenções perpetradas pelo Estado, mais especificamente pela União Federal, as quais se dividem, de acordo com Laubadère ${ }^{100}$, em globais, setoriais e pontuais. Distinguem-se, assim, em:

[...] intervenções que afetam a economia em seu conjunto (intervenções globais) ou num determinado sector apenas (sectoriais), tendo umas e outras como traço comum o facto de serem gerais, e, por outro lado, as intervenções pontuais, que dizem respeito a uma situação particular, por exemplo uma empresa.

Conforme poderá ser constatado adiante, ao conceder crédito ou subvenções econômicas a determinado setor - turismo, agricultura, sucroalcooleiro, siderúrgico etc. -, estar-se-á perante uma intervenção setorial de fomento, pois o Estado se vale de sua receita pública ou da realização de despesas para incentivar determinadas e específicas atividades conferidas à iniciativa privada.

Ambas as intervenções - globais e setoriais -, portanto, diferem da intervenção pontual que se dá quando o Estado firma diretamente com determinada empresa um contrato de viabilização, convênios administrativos ${ }^{101}$, parcerias público-privadas ${ }^{102}$ ou, até

\footnotetext{
${ }^{100}$ LAUB ADÈRE, André de. Direito público económico, p. 28.

${ }^{101}$ De acordo com Hely Lopes Meirelles, "Convênios administrativos são acordos firmados por entidades públicas de qualquer espécie, ou entre estas e organizações particulares, para realização de objetivos de interesse comum dos partícipes." (MEIRELLES, Hely Lopes. Direito administrativo brasileiro, p. 386).

102 Instituídas pela Lei $\mathrm{n}^{\mathrm{o}} 11.079 / 2004$, alterada pela Lei $\mathrm{n}^{\mathrm{o}}$ 11.409/2011, e pela Medida Provisória $\mathrm{n}^{\mathrm{o}}$ $575 / 2012$, posteriormente convertida na Lei $\mathrm{n}^{\mathrm{o}}$ 12.766/2012, as parcerias público-privadas constituem uma das modalidades de contrato administrativo e, embora existam várias espécies, a referida Lei $\mathrm{n}^{\mathrm{o}}$ 11.079, no
} 
mesmo, quando injeta capital em uma empresa específica com o propósito de evitar sua quebra, estatizando-a ou não. Neste último aspecto, é importante mencionar a posição de Luís S. Cabral de Moncada ${ }^{103}$, segundo o qual, referidas intervenções devem respeitar critérios estratégicos gerais e de ordem objetiva.

De acordo com a peça orçamentária e a leitura que a iniciativa privada venha a fazer dela, pode optar por investir nos planos do Estado ou não. No caso de haver disponibilidade de recursos públicos a serem empregados em determinadas áreas ou setores, o Estado, ainda que tenha agido sem esse propósito, poderá influenciar a iniciativa privada, de forma global, setorial ou pontual, a adotar medidas positivas e, assim, realizar investimentos que vão desde a capacitação e contratação de mão de obra até a aquisição de bens e materiais, ou, de outro modo, a adotar medidas negativas que possam redundar na restrição de investimentos e contenção de despesas e, portanto, efeitos indesejáveis.

Como adverte John Maynard Keynes, é possível “que as eventuais modificações da política fiscal tenham, pelo menos, nas expectativas, maior influência do que a própria taxa de juro" ${ }^{104}$. Na atualidade, e levando em consideração as ideias de John Maynard Keynes, pode-se dizer que o orçamento, ao estampar a política fiscal do governo, produz expectativas positivas ou negativas, influenciando o domínio econômico na tomada de decisões que impactarão a economia e o próprio desenvolvimento econômico.

O que se vê é que as pretensões do Estado, traduzidas no orçamento público, podem gerar efeitos tanto positivos quanto negativos, a depender de seu planejamento, conforme demonstrado adiante.

Por fim, não se pode perder de vista o fato de que, qualquer medida a ser adotada pelo Estado deverá ser tomada em conformidade com a lei e com os objetivos fixados no pacto social, ou seja, na Constituição Federal brasileira.

art. $2^{2}$, reservou a expressão para apenas duas modalidades específicas: "parceria público-privada é o contrato administrativo de concessão, na modalidade patrocinada ou administrativa". Em suma, como esclarece Maria Sylvia Zanella di Pietro, "pode-se dizer que a parceria público-privada é o contrato administrativo de concessão que tem por objeto (a) a execução de serviço público, precedida ou não de obra pública, remunerada mediante tarifa paga pelo usuário e contraprestação pecuniária do parceiro público, ou (b) a prestação de serviço de que a Administração Pública seja a usuária direta ou indireta, com ou sem execução de obra e fornecimento e instalação de bens, mediante contraprestação do parceiro público" (DI PIETRO, Maria Sylvia Zanella. Direito administrativo, p. 315-316).

${ }^{103}$ MONCADA, Luís S. Cabral de. Direito económico, p. 41-42.

${ }^{104}$ KEYNES, John Maynard. Teoria geral do emprego, do juro e da moeda, p. 85. 


\subsection{Intervenção, ideologia e dominação}

Como demonstrado, o Estado, legitimamente representado e na qualidade de agente normativo e regulador da atividade econômica, bem como fundado na valorização do trabalho humano e na livre iniciativa, justifica o exercício do poder de intervir no domínio econômico, o qual deve dar-se em consonância com os propósitos traçados na Constituição Federal, e desde que com observância dos princípios enumerados no art. 170.

Embora a Constituição brasileira anuncie a instituição de um Estado capaz de assegurar a harmonia social comprometida com a ordem interna e internacional sob os valores da justiça, não há como negar que inúmeros fatores - sociais, econômicos e políticos - acabam influenciando a alteração da posição do Estado perante a sociedade e repercutindo na forma de governo.

Os objetivos impostos pela Constituição ao Estado são realizados por este com supedâneo no arcabouço jurídico capaz de legitimar suas ações. A regulação jurídica, em seu todo, mostra-se, muitas vezes, meramente aparente quando se vai além do pensamento que se está condicionado a realizar, uma vez que restrito a uma realidade jurídica autônoma e exclusiva. Afinal, os Estados mais fortes dispõem de meios para modificar o direito quando isso lhes convém ${ }^{105}$, independentemente da vontade de seu povo.

Atento a essa questão, Hobbes, ao tratar da essência do Estado, define-o como sendo "uma pessoa instituída, pelos atos de uma grande multidão, mediante pactos recíprocos uns com os outros, como autora, de modo a poder usar a força e os meios de todos, da maneira que achar conveniente, para assegurar a paz e a defesa comum" ${ }^{06}$.

Com efeito, o pacto social defendido por Thomas Hobbes se traduz em um documento solene cujos termos foram discutidos em assembleia e que, atualmente, denomina-se Constituição; esta, por sua vez, define, de acordo com cada Estado e seu momento histórico, sua estrutura, atribuições e limites. Em suma, estabelece o pacto solene já mencionado e com o qual se concorda em parte com a posição do filósofo, pois não se

${ }^{105}$ DALLARI, Dalmo de Abreu. Elementos de teoria geral do estado. 31. ed. São Paulo: Saraiva, 2012. p. 260 .

${ }^{106}$ HOBBES, Thomas. Leviatã, ou matéria, forma e poder de um estado eclesiástico e civil. Traduzido por Rosina D’ Angina. 2. ed. São Paulo: Martin Claret, 2012. p. 140. (Coleção A obra prima de cada autor). 
pode aceitar que esta compreenderia a renúncia ampla e irrestrita de direitos, dentre os quais se destaca a liberdade.

De qualquer modo, e ainda que uma multidão confira plena força e poder a um homem, ou a uma assembleia de homens, como proposto por Thomas Hobbes, e mesmo que esse possa parecer o caminho capaz de defendê-los das invasões estrangeiras e das injúrias que uns possam fazer aos outros, reconhecendo cada membro dessa multidão como autor dos atos que aquele(s) que o representa(m) possa(m) praticá-lo em seu nome, em evidente ato de cessão do direito de governar a si mesmo ${ }^{107}$, é impossível aceitar que o faça em nome de todos.

Representante de uma maioria e não da totalidade, aquele que age em nome do Estado em determinado momento histórico inevitavelmente acaba praticando atos indicadores do propósito de assegurar a manutenção do poder ou defender seus interesses privados, ideias e ideais, ou, até mesmo, daqueles que o apoiam ou cercam.

Esteja-se, portanto, diante de um Estado político, ou por instituição, como denominou Thomas Hobbes ${ }^{108}$, interesses divergentes, conflitantes e digressivos sempre existirão. Os homens se envolvem com recorrência em competição pela honra e pela dignidade; só encontram a felicidade na comparação com os outros homens e, ainda, julgam-se mais sábios e mais capacitados que os demais para o exercício do Poder Público ${ }^{109}$.

Em razão do exposto, ao tratar da intervenção do Estado no domínio econômico, é preciso analisá-la de maneira a ir além do paradigma axiomático proposto e, com isso, apresentar uma visão de natureza axiológica, para que se possa entender a intervenção do Estado não apenas como decorrência de mera previsão legal, mas, também, como resultado da evolução do pensamento e da história.

O detentor de poder que lhe foi atribuído pelo Estado exerce-o na qualidade de dominante ou dominador. Para coibir o uso indiscriminado da força, o sistema jurídico simplesmente tenta impor limites aos seus detentores, evitando, assim, a "guerra de todos contra todos", de que falava Thomas Hobbes.

\footnotetext{
${ }^{107}$ HOBBES, Thomas. Leviatã, ou matéria, forma e poder de um estado eclesiástico e civil, p. 140.

${ }^{108}$ Ibidem, p. 141.

${ }^{109}$ Ibidem, p. 139.
} 
Mais ainda. Esse poder, de acordo com Michel Foucault, deve ser compreendido tomando-se em consideração os símbolos, rituais, liturgias e seus personagens, o seu método, ou, como prefere o filósofo, de sua genealogia, isto é, por meio de "pesquisas genealógicas múltiplas, ao mesmo tempo redescoberta exata das lutas e memória bruta dos combates" $" 110$.

Como proposto por Michel Foucault, é preciso atentar para o que se faz e para as desculpas que se dá ao justificar o que se faz no exercício do poder, pois este detém funcionalidade econômica ao ser dotado, essencialmente, do papel de manter relações de produção e reproduzir uma dominação de classe que o desenvolvimento constitui uma modalidade própria da apropriação das forças produtivas, tornando-as possíveis.

O poder se sustenta na obediência submissa dos liderados, no entanto, as estratégias para a conquista e manutenção do poder não se resumem apenas às regras de como subjugá-los.

O indivíduo que detém o poder ou o almeja alcançar nem sempre o faz com o propósito de atingir determinada posição de prestígio, ou age com o intuito de se enriquecer. Como mostra Michel Foucault, a luta travada vai além - trava-se a luta pelos saberes, pela consagração das condições de possibilidade de dominação. Luta-se, enfim, pela difusão, manutenção ou alteração de determinados saberes e não por cargos, benefícios ou status sociais.

A propósito, Baruch de Espinosa já dizia que "o direito do soberano, como o do indivíduo, no estado de natureza, mede-se pelo seu poder"111. Ainda segundo o autor ${ }^{112}$ :

[...] um homem tem outro sob seu poder, quando o tem preso, ou quando lhe arrebatou as armas e os meios de defender-se ou de evadir-se, ou, ainda, quando o domina pelo medo, ou, enfim, quando o domina de tal modo pelos benefícios, que fá-lo obedecer aos caprichos do seu benfeitor, de preferência às suas próprias inclinações e viver à discrição deste, mais que pelas inclinações da sua própria vontade.

\footnotetext{
${ }^{110}$ FOUCAULT, Michel. Microfísica do poder. Organização, introdução e revisão técnica de Roberto Machado. 25. ed. São Paulo: Graal, 2012. p. 267.

${ }^{111}$ SPINOZA, Baruch de. Tratado político. Tradução e prefácio de José Pérez. Edição especial. Rio de Janeiro: Nova Fronteira, 2013. p. 47.

${ }^{112}$ Ibidem, p. 41.
} 
Os fatos apresentados justificam anuir com o posicionamento de Max Weber, segundo o qual a dominação constitui um dos elementos mais importantes da ação social ${ }^{113}$ e, ainda, embora nem toda forma de ação social revele uma estrutura de domínio, todas as suas esferas sofrem profunda influência das estruturas de dominação, pois sua estrutura e seus desdobramentos são decisivos na determinação da forma da ação social e destinadas a determinado objetivo ${ }^{114}$.

Ao se referir ao termo dominação como sendo o desejo manifestado (ordem) pelo(s) líder(es) em influenciar a conduta de um ou mais liderados, chamando-a, se vista pelo outro lado, de obediência ${ }^{115}$, Weber afirma ser a dominação um caso especial de poder em que o dominador, ao exercê-la, não a aplica tão somente para atingir propósitos puramente econômicos, mesmo sendo estes uma consequência frequente e um de seus instrumentos mais importantes ${ }^{116}$.

Max Weber ${ }^{117}$ classifica a dominação em: (i) legal ou legal-racional; (ii) tradicional; e (iii) carismática.

A dominação legal é a mais estável, pois se baseia em normas que podem ser criadas e modificadas a qualquer tempo, e desde que legitimamente instituídas. Tem a "burocracia" como seu tipo mais puro e como princípio fundamental a hierarquia funcional, cuja obediência se presta não à pessoa que detém o poder, mas ao cargo estatuído.

Esse modelo de dominação aplica-se inteiramente ao Estado moderno, em que o governante eleito passa a exercer o poder por conta do cargo que assume, o qual não é atribuído à sua pessoa. Ao término do mandato, o poder desse governante permanecerá

\footnotetext{
${ }^{113}$ Weber cita quatro tipos de ação social: (i) ação social tradicional, em que o indivíduo a toma de modo automático, sem pensar para realizá-la; (ii) ação social afetiva, em que a participação do emocional do agente é maior que seu racional (v.g., relações familiares); (iii) ação social racional quanto aos valores, em que se requer do indivíduo uma ética da convicção, um senso de missão a cumprir em função dos valores que preza; e (iv) ação social racional quanto aos fins, em que o indivíduo avalia, levando em consideração os fins que pretende atingir e os meios disponíveis para isso, se a ação que pretende realizar vale a pena, consideradas as dificuldades a serem enfrentadas (WEBER, Max. Economia e sociedade. Trad. de Regis Barbosa e Karen Elsabe Barbosa, rev. téc. de Gabriel Cohn. Reimpressão. Brasília: Editora Universidade de Brasília, 1999. v. II, p. 187 e ss.).

${ }^{114}$ Idem. O direito na economia e na sociedade. Tradução de Marsely De Marco Martins Dantas. São Paulo: Ícone, 2011. p. 295/296.

115 Ibidem, p. 302.

${ }^{116}$ Ibidem, p. 296.

${ }^{117}$ Idem. Economia e sociedade: fundamentos da sociologia compreensiva. Trad. por Regis Barbosa e Karen Elsabe Barbosa; rev. téc. de Gabriel Cohn. Brasília: Reimpressão. Editora Universidade de Brasília, 1999, 2009. v. I, p. 139-161.
} 
atrelado ao cargo estabelecido ou criado por um estatuto (uma norma), permitindo que outra pessoa, posteriormente, assuma o mesmo cargo e a responsabilidade pelo poder.

$\mathrm{Na}$ dominação tradicional, a autoridade é pura e simplesmente suportada pela existência de uma fidelidade tradicional. O governante é o patriarca ou o senhor, os dominados são os súditos, e o funcionário é o servidor. Nesse modelo, presta-se obediência à pessoa por respeito, em virtude da tradição de uma dignidade pessoal que se julga sagrada.

Todo o comando dessa modalidade de dominação se prende intrinsecamente à tradição e não a normas, classificando-a Max Weber como sendo uma dominação estável, em razão da solidez e estabilidade do meio social que se acha sob a dependência direta e imediata do aprofundamento da tradição na consciência coletiva.

Na dominação carismática, a autoridade é suportada graças à devoção afetiva dos dominados. Assenta-se sobre as "crenças" transmitidas por profetas, sobre o "reconhecimento" que pessoalmente alcançam os heróis e os demagogos, durante as guerras e revoluções, nas ruas e nas tribunas. A fé e o reconhecimento são convertidos em deveres invioláveis que lhes são devidos pelos governados, mostrando-se, assim, instáveis por não haver nada capaz de assegurar sua perpetuação.

Max Weber ${ }^{118}$ conclui:

Toda administração precisa, de alguma forma, da dominação, pois, para dirigi-la, é mister que certos poderes de mando se encontrem nas mãos de alguém. $\mathrm{O}$ poder de mando pode ter aparência muito modesta, sendo o dominador considerado o "servidor" dos dominados e sentindo-se também como tal. Isso ocorre, em mais alto grau, na chamada administração democrática.

Cada dominante, a todo instante e com o intuito de subjugar a maioria, de se manter no poder, vale-se de sua ideologia e tenta impor aos membros da sociedade o que devem pensar, sentir, valorizar, fazer ou deixar de fazer e, com isso, justificar suas ações ou

\footnotetext{
${ }^{118}$ WEBER, Max. Economia e sociedade: fundamentos da sociologia compreensiva, p. 193.
} 
omissões. Neste ponto, é pertinente trazer à colação o conceito de ideologia empregado pela filósofa Marilena Chauí1 ${ }^{19}$, segundo a qual:

\begin{abstract}
A ideologia é um conjunto lógico, sistemático e coerente de representações (ideias e valores) e de normas ou regras (de conduta) que indicam e prescrevem aos membros de uma sociedade o que devem pensar e como devem pensar, o que devem valorizar e como devem valorizar, o que devem sentir e como devem sentir, o que devem fazer e como devem fazer. Ela é, portanto, um conjunto de ideias ou representações com teor explicativo (ela pretende dizer o que é a realidade) e prático ou de caráter prescritivo, normativo, regulador, cuja função é dar aos membros de uma sociedade dividida em classes uma explicação racional para as diferenças sociais, políticas e culturais, sem jamais atribuí-las à divisão da sociedade em classes, determinada pelas divisões na esfera da produção econômica. Pelo contrário, a função da ideologia é ocultar a divisão social das classes, a exploração econômica, a dominação política e a exclusão cultural, oferecendo aos membros da sociedade o sentimento de uma mesma identidade social, fundada em referenciais unificadores como, por exemplo, a Humanidade, a Liberdade, a Justiça, a Igualdade, a Nação.
\end{abstract}

Em síntese, o dominador utiliza o discurso universal, o imaginário, não no sentido de irrealidade ou fantasia, mas de um conjunto de imagens ou representações sistematizadas com coerência, para justificar uma suposta realidade concreta, provocando inversão entre o "de direito" e o "de fato".

Além disso, o dominador fornece aos sujeitos sociais e políticos um espaço de ação que vai além do corpus de representação coerente para explicar o real, dando-lhes um corpus de normas coerentes para orientar a prática, formada de regras corretas para a ação $^{120}$.

Sustenta-se o discurso ideológico justamente porque "não pode dizer até o fim aquilo que pretende dizer. Se o disser, se preencher todas as lacunas, ele destruirá a si mesmo como ideologia. A força do discurso ideológico provém de uma lógica que poderíamos chamar de lógica de lacuna, lógica do branco, lógica do silêncio" ${ }^{\text {,121. }}$.

E, como bem salienta Regis Fernandes de Oliveira, "a dominação tomou rumos refinados e se impõe à vontade do outro através de ritos sacrificais sofisticados" ${ }^{122}$.

\footnotetext{
${ }^{119}$ CHAUÍ, Marilena. Manifestações ideológicas do autoritarismo brasileiro. Organizado por André Rocha. Belo Horizonte: Autêntica; São Paulo: Fundação Perseu Abramo, 2013. (Escritos de Marilena Chauí, 2), p. 117.

${ }^{120}$ Ibidem, p. 124/126.

${ }^{121}$ Ibidem, p. 127.

122 OLIVEIRA, Regis Fernandes de. Gastos públicos. São Paulo: Revista dos Tribunais, 2012a. p. 137.
} 
Com efeito, nada mais significativo que a possibilidade de intervir na atividade exercida pela iniciativa privada para demonstrar o poder e impor desejos particulares - seja na qualidade de representante da coletividade, seja na qualidade de representante do Estado, valem-se todos do "interesse público", da Nação, da Pátria, do Progresso, da Família, do próprio Estado, enfim, "de uma referência unificadora ideológica" como justificativa ou argumento hábil à prática de determinados atos de vontade, escamoteando "a percepção de um império dos homens sobre os homens" 123.

As ideais dominantes de uma época são as da classe então dominante. Aparecem como representação do real e como verdade para os dominadores, como normas para a ação, tendo como pressuposto atender a certos fins, que seriam os mesmos para todos ${ }^{124}$.

Como lembra Paulo Freire ${ }^{125}$, há um ciclo ad infinitum.

O autor afirma ${ }^{126}$ que, quando a superação

[...] se realiza em termos autênticos, com a instalação de uma nova situação concreta, de uma nova realidade inaugurada pelos oprimidos que se libertam, é que os opressores de ontem não se reconheçam em libertação. Pelo contrário, vão sentir-se como se realmente estivessem sendo oprimidos.

Paulo Freire ${ }^{127}$ ainda diz:

Na análise da situação concreta, existencial, de opressão, não podemos deixar de surpreender o seu nascimento num ato de violência que é inaugurado, repetimos, pelos que têm poder.

Esta violência, como um processo, passa de geração a geração de opressores, que se vão fazendo legatários dela e formando-se no seu clima geral. Este clima cria nos opressores uma consciência fortemente possessiva. Possessiva do mundo e dos homens.

Mesmo que o Estado, ou aqueles que o representam, eleja qualquer uma das formas ou critérios de intervenção, seja pela absorção, participação, direção, fomento ou indução, a escolha dar-se-á em consonância com interesses pessoais, de acordo com suas convicções

\footnotetext{
${ }^{123}$ CHAUÍ, Marilena. Manifestações ideológicas do autoritarismo brasileiro, p. 128.

${ }^{124}$ Ibidem, p. 131.

${ }^{125}$ FREIRE, Paulo. Pedagogia do oprimido. Rio de Janeiro: Nova Fronteira, 2012. p. 50

${ }^{126}$ Ibidem, loc. cit.

${ }^{127}$ Ibidem, p. 50-51.
} 
e, definitivamente, com o propósito de se perpetuar no poder, pois certa margem de liberdade ou discricionariedade ${ }^{128}$ sempre existirá, bastando, para tanto, beneficiar determinado grupo, aqueles que exerçam determinada atividade ou, ainda, convencer alguns de sua realidade.

Esses benefícios, como anotado por Weber, não necessariamente são econômicos, mas são facilmente percebidos quando alguém ou algum grupo ou instituição é contemplado com a concessão de um serviço público, incentivos fiscais, linhas de créditos, subvenções econômicas, subsídios, renúncias de receita etc., em detrimento de outros, pois não estão direta e intimamente ligados ao dominante.

Em suma, os dominantes recorrem a uma série de instrumentos para dominar, isto é, para "impor ao comportamento de terceiros a vontade própria" 129 mediante carisma, afeto, hierarquia ou até mesmo em decorrência de um estatuto, ou seja, oriundo do cargo ocupado pelo dominante e do qual se utiliza para, e durante o período nele mantido, ditar regras, estabelecer normas e, com isso, beneficiar aqueles não só o apoiam, mas também lhe obedecem.

\footnotetext{
${ }^{128}$ No dizer de Bandeira de Mello, "fala-se em discricionariedade quando a disciplina legal faz remanescer em proveito e a cargo do administrador uma certa esfera de liberdade, perante o quê caber-lhe-á preencher com seu juízo subjetivo, pessoal, o campo de indeterminação normativa, a fim de satisfazer no caso concreto a finalidade da lei” (MELLO, Celso Antônio Bandeira de. Curso de direito administrativo, p. 970).

${ }^{129}$ WEBER, Max. Economia e sociedade: fundamentos da sociologia compreensiva, p. 188.
} 


\section{O ORÇAMENTO PÚBLICO COMO INSTRUMENTO DE PLANEJAMENTO E INTERVENÇÃO}

\subsection{Concepção atual de orçamento público}

Em razão dos objetivos delineados para o presente trabalho, e como se procedeu ao longo do início do Capítulo anterior quando se tratou da intervenção do Estado no domínio econômico, é imprescindível traçar um breve histórico da figura do orçamento. Para tanto, partir-se-á de sua concepção clássica até a hodierna.

Saliente-se que ambos os institutos - orçamento público e intervenção estatal estão intimamente atrelados aos acontecimentos políticos, econômicos e financeiros que se sucederam no tempo.

Deveras, extrai-se a concepção clássica de orçamento das revoluções liberais dos séculos XVII e XVIII, ou seja, do advento do Estado Moderno ${ }^{130}$ e início do regime representativo, que o qualificava como sendo mera peça de previsão das receitas e autorização das despesas públicas, as quais eram simplesmente classificadas por objetos, sem pretensão alguma de dispor acerca das reais necessidades do Estado ${ }^{131}$.

Embora no Estado absoluto já se possa verificar a presença da autorização para a instituição e cobrança de impostos, não há como afastar o fato de que esse regime se qualificava pela concentração dos poderes do Estado na pessoa dos soberanos, instalado no interior de cada organização política ${ }^{132}$. Com isso, era impossível distinguir a "Fazenda do Rei e a do Estado, as despesas do Rei e do Reino, as rendas da Coroa e do Reino" ${ }^{133}$, o que afastava a ideia de que durante o período mencionado fosse necessária qualquer

\footnotetext{
130 TORRES, Ricardo Lobo. Tratado de direito constitucional, financeiro e tributário: o orçamento na Constituição. 3. ed. Rio de Janeiro: Renovar, 2008. v. V, p. 2-3.

${ }^{131}$ SILVA, José Afonso da. Orçamento programa no Brasil. São Paulo: Revista dos Tribunais, 1973. p. 1.

${ }^{132}$ MENEZES, Anderson de. Teoria geral do estado. Rio de Janeiro: Forense, 1960. p. 32.

133 GODINHO, Vitorino Magalhães. Finanças públicas e estrutura do estado. Ensaios sobre a história de Portugal II. In: TORRES, Ricardo Lobo. Op. cit., p. 4.
} 
autorização para a criação e cobrança de tributos, assim como para a realização de despesas $^{134}$.

Diante dos abusos perpetrados pelos governantes, o orçamento, em um primeiro momento, atuou como instrumento político de controle da tributação excessiva, em que o Legislativo passou a exercer fundamental controle sobre o Executivo no tocante à instituição e arrecadação de tributos.

O consentimento sobre a arrecadação exprimia, assim, os primeiros passos do orçamento, no que tange a atribuir autorização à arrecadação, valendo-se os soberanos de seus domínios para prover as despesas ordinárias do reino e de receita extraordinária para honrar as despesas provenientes, geralmente, de guerras.

Mais tarde, verificou-se também a necessidade de se estabelecer um controle sobre o gasto público, o que resultou na imposição de limites ao Estado e se concretizou com a institucionalização da anualidade orçamentária. Conforme adverte Aliomar Baleeiro ${ }^{135}$, a função do controle político exercido pelo Poder Legislativo sobre o Executivo era a de estabelecer um equilíbrio entre receita e despesas. Em suma, Baleeiro ${ }^{136}$ anota:

\footnotetext{
Durante os dois primeiros séculos, desde a revolução britânica de 1688, o orçamento, como instrumento político, foi o escudo para a defesa dos contribuintes contra os governos. Era, sobretudo, um dique para conter as despesas e, consequentemente, deter o apelo à tributação.

$[\ldots]$.

O orçamento, por essas razões, floresceu em sua primeira fase, como processo de fiscalização financeira e cerceamento das tendências peculiares dos governantes dissociados dos interesses gerais das massas. Estabelecido para cada ano, forçava o rei à convocação periódica e regular dos representantes em parlamento.
}

É no liberalismo, e com as grandes revoluções liberais no fim do século XVIII, que o Estado se constitui plenamente, dando início a uma nova sociedade e deixando para trás aquilo que os franceses chamaram de Ancien Régime, então caracterizado pelo absolutismo real, dotado de privilégios diversos de origem feudal, submissão da atividade econômica a interesses do monarca ou da nobreza e a sobreposição de direitos.

${ }^{134}$ TORRES, Ricardo Lobo. Tratado de direito constitucional, financeiro e tributário: o orçamento na Constituição, p. 3.

${ }^{135}$ BALEEIRO, Aliomar. Uma introdução à ciência das finanças. 14. ed. atual. por Flávio Bauer Novelli. Rio de Janeiro: Forense, 2004. p. 395.

${ }^{136}$ Ibidem, loc. cit.. 
Como decorrência do movimento constitucionalista, estabeleceu-se um pacto entre os cidadãos, assegurando-lhes uma série de direitos tidos como fundamentais e inerentes à condição humana, os quais impunham aos Estados a necessidade de melhor se organizarem. Em suma, consolidava-se no mundo contemporâneo a ideia de Constituição, o que guarda evidente correlação com o modelo teórico do contrato social desenvolvido por Jean-Jacques Rousseau ${ }^{137}$, segundo o qual:

\begin{abstract}
Instantaneamente, em vez da pessoa individual de cada contratante, esse ato de associação produz um corpo moral e coletivo composto de tantos membros quantos votos tem a assembleia, o qual recebe desse mesmo ato sua unidade, seu $e u$ comum, sua vida e sua vontade. Essa pessoa pública, que se forma assim pela união de todas as outras, tomava antigamente o nome de Cidade e toma agora o de República ou de corpo-político, que é chamado por seus membros de Estado quando é passivo, Soberano quando é ativo, Potência quando comparado a seus semelhantes. Quanto aos associados, eles tomam coletivamente o nome de povo e se chamam em particular de Cidadãos, enquanto partícipes de uma autoridade soberana, e Súditos, enquanto submetidos às leis do Estado.
\end{abstract}

Nesse cenário insere-se o orçamento como peça fundamental de atuação do Estado, em que a limitação da autoridade pelo delineamento de poderes e a declaração dos direitos do homem passam a ser assegurados e garantidos por um documento sociojurídicopolítico, denominado Constituição, e que lhe impõe a obrigação de estabelecer maior controle e equilíbrio entre a receita e as despesas.

Informada pelo próprio princípio do liberalismo, a atividade financeira do Estado restringia-se ao indispensável à satisfação de suas necessidades primárias, as quais se resumiam à manutenção da segurança (interna e externa) e à promoção da justiça, sem que lhe fosse permitido exercer ingerência alguma na ordem econômica e social.

\title{
A propósito, Ricardo Lobo Torres ${ }^{138}$ disserta:
}

\begin{abstract}
O Estado Fiscal dessa fase histórica, que era um dos aspectos do Estado GuardaNoturno, ou seja, do Estado que se restringia ao exercício do poder de polícia, da administração da justiça e da prestação de uns poucos serviços públicos, não necessitava de sistemas tributários amplos, por não assumir demasiados encargos na via da despesa pública e por não ser o provedor da felicidade do povo, como acontecia no patrimonialismo. A expressão mais significativa do Estado Orçamentário Liberal talvez a tenha oferecido J. B. Say: "Le meilleur de tous les
\end{abstract}

\footnotetext{
${ }^{137}$ ROUSSEAU, Jean-Jacques. Do contrato social, p. 66-67.

138 TORRES, Ricardo Lobo. Tratado de direito constitucional, financeiro e tributário: o orçamento na Constituição, p. 11.
} 
plans de finance est de dépenser peu, et le meilleur de tous les impôts est le plus petit". (grifo do original)

Ao lado do modelo clássico de orçamento financeiro do Estado, o qual consistia, nas palavras de Aliomar Baleeiro, em um "quadro de técnica contábil para coordenar comparativamente despesas e receitas públicas, de sorte que o Estado possa imprimir ordem e método na Administração" ${ }^{139}$, outros países chegavam à conclusão de que devia ser apresentado, anualmente, um quadro de contas gerais da nação, no qual deveriam ser incluídos, além do setor público, as empresas e os particulares. Esse quadro consistiria em:

[...] uma recapitulação dos elementos da renda nacional: sua formação, seu circuito, sua repartição. Esse orçamento, chamado por Beveridge de nacional ou humano, passaria a figurar não como autorização mas como um roteiro da economia, onde se alicerça o orçamento do Estado ${ }^{140}$.

Nas palavras de José Afonso da Silva ${ }^{141}$, a função do orçamento clássico poderia ser definida como se segue:

\begin{abstract}
A função fundamental do orçamento clássico, historicamente, "foi sempre o de assegurar o controle político das atividades governamentais; controle que se fazia através dos órgãos legislativos sobre as atividades financeiras dos órgãos executivos. Era um orçamento político, contábil e financeiro apenas. Não tinha outra pretensão, não visava a outra finalidade".
\end{abstract}

Ainda que fosse elaborado anualmente, visava-se, com o orçamento, apenas empreender maior controle político às atividades dos governantes, sem pretensão alguma de lhe dotar de outros atributos ou finalidades, que não mero documento de cunho financeiro.

Com o passar do tempo e a difusão da instrução primária, o aperfeiçoamento dos métodos eleitorais, o aprimoramento do sufrágio universal e a penetração política das massas nos negócios públicos, verificou-se uma crescente inversão das despesas públicas nos objetivos dos Estados ${ }^{142}$, até que, no início do século XX, dá-se a institucionalização do denominado Estado do Bem-estar Social - o Welfare State - e o consequente

\footnotetext{
${ }^{139}$ BALEEIRO, Aliomar. Uma introdução à ciência das finanças, p. 388.

${ }^{140}$ DEODATO, Alberto. Manual de ciência das finanças. 17. ed. São Paulo: Saraiva, 1980. p. 277.

141 Ibidem, p. 2.

${ }^{142}$ BALEEIRO, Aliomar. Op. cit., p. 396.
} 
alargamento dos gastos com saúde, educação e, principalmente, previdência social, o que culmina com o desequilíbrio orçamentário e a eclosão da denominada crise do Estado Liberal.

A ineficiência do Estado em atender às reivindicações sociais e garantir o pleno funcionamento do mercado fez que se impusesse aos governantes não apenas maior grau de intervencionismo na economia como anteriormente apontado, mas também a necessidade de maior controle entre despesas e receitas, pois os recursos destinados à promoção do desenvolvimento econômico se tornavam insuficientes.

A teoria orçamentária do Estado Liberal perdia, assim, seu fundamento. A ideia de equilíbrio entre receitas e despesas e seu caráter iminentemente político deixavam de ter consistência, tendo as Constituições de diversos países se modificado em razão da crise de 1929, a qual se instaurou com a quebra da Bolsa de Nova York e impôs a adoção de determinadas medidas pelo Estado, que passou a ter mais autorização para intervir no domínio econômico e social, conforme já salientado.

Instaurou-se uma nova forma de organização política e, em particular no Brasil, juntamente com a ideia de uma ordem econômica constitucional, "a disciplina constitucional do orçamento se amplia a partir de 1937, para atender à nova orientação política e econômica" ${ }^{143}$, embora a Constituição de 1824 já previsse a obrigatoriedade do orçamento, repartindo as competências políticas entre a Assembleia e o Executivo ${ }^{144}$.

A Constituição republicana, de 24 de fevereiro de 1891, já havia atribuído ao Congresso Nacional a obrigação e competência para "orçar a receita, fixar a despesa federal anualmente e tomar as contas da receita e despesa de cada exercício financeiro" (art. 37, § $1^{\underline{0}}$ ), no entanto, somente com a Constituição de 1946 é que o orçamento passa "a ser visto não mais como peça financeira, mas como um programa de governo, através do qual havia de se demonstrar não apenas a elaboração financeira, mas também definir a orientação do governo" ${ }^{145}$.

\footnotetext{
143 TORRES, Ricardo Lobo. Tratado de direito constitucional, financeiro e tributário: o orçamento na Constituição, p. 5.

${ }^{144}$ MASSONETTO, Luís Fernando. O direito financeiro no capitalismo contemporâneo: a emergência de um novo padrão normativo. 2006. Tese (Doutorado) - Universidade de São Paulo, São Paulo, 2006, p. 59-60. ${ }^{145}$ OLIVEIRA, Regis Fernandes de. Curso de direito financeiro. 4. ed. rev. atual. e ampl. São Paulo: Revista dos Tribunais, 2011.p. 365.
} 
Após o golpe militar de 1964, com o advento da Constituição de 1967 (art. 67, § $1^{\underline{o}}$ ), tem-se, pela primeira vez, restrito o poder de emenda, ao se estabelecer que "não serão objeto de deliberação emendas de que decorra aumento de despesa global ou de cada órgão, projeto ou programa".

Alterações e inovações, de fato, significativas são introduzidas pela Constituição cidadã de 1988, destacando-se, dentre elas, o poder de emenda do parlamentar, a instituição do plano plurianual, bem como da lei de diretrizes orçamentárias, a ampliação do controle das contas públicas e a instituição do planejamento no setor público como preceito fundamental.

E, como bem pondera José Afonso da Silva, “em verdade, a característica essencial dos orçamentos públicos, hoje em dia, é a que o define como um programa, como um instrumento de planejamento, de direção, e de contrôle da administração pública" ${ }^{146}$.

Em outras palavras, atribuiu-se ao orçamento novas funções, pois ele "passou a ser um instrumento de programação econômica, de programação de ação governamental, em consonância com a economia global da comunidade a que se refere"147. As disputas por espaço e força impulsionaram a necessidade de o Estado melhor manipulá-las e distribuílas, a fim de viabilizar um crescimento competitivo equânime, dotado de melhor distribuição de renda.

As alterações e inovações apontadas também se mostraram um tanto quanto ineficazes. A crise do Estado do Bem-estar Social, desencadeada nas décadas de 1980 e 1990, impôs novas modificações e consequências ao perfil da Constituição Orçamentária, conforme relata Ricardo Lobo Torres ${ }^{148}$ :

Influenciado pelas idéias de Keynes, o Estado de Bem-estar Social procura aumentar os impostos e as fontes da receita, ao mesmo tempo em que amplia as prestações públicas, principalmente no campo dos incentivos fiscais, dos subsídios, da previdência social e da seguridade. No final da década de 1970, após as sucessivas crises do petróleo, o Estado do Bem-estar Social passa a sofrer séria contestação, em virtude do crescimento insuportável da dívida pública, dos orçamentos repetidamente deficitários, da recessão econômica e do abuso na concessão de benefícios com os dinheiros públicos; a sua dimensão assistencialista conduz ao incremento das despesas com a previdência e a

\footnotetext{
${ }^{146}$ SILVA, José Afonso da. Orçamento Programa no Brasil, p. 39.

${ }^{147}$ Ibidem, p. 41.

148 TORRES, Ricardo Lobo. Tratado de direito constitucional, financeiro e tributário: o orçamento na Constituição, p. 13.
} 
seguridade social sem a contrapartida da entrada de ingressos compatíveis com o volume dos encargos e, não raro, com o seu custeio pela incidência exageradamente progressiva dos impostos.

O excessivo intervencionismo do Estado no domínio econômico e social, do qual decorre a ampliação do papel do Estado e, portanto, a necessidade de se aumentar os impostos e criar novas fontes de receitas, torna-o ineficiente, inflado e custoso. A propósito, Aliomar Baleeiro ${ }^{149}$ salienta:

As idéias e práticas buscam empregar o orçamento como o aparelho para combater fases de depressão e de desemprego, promover investimentos, ou para conter as quadras inflacionárias. Os velhos princípios de técnica orçamentária, consagrados pelas gerações anteriores, vergam ao peso dessa tarefa enorme.

Com isso, passam a imperar o ideal do equilíbrio orçamentário e as ideias de economicidade e transparência das despesas, a qual constitui o grande desafio do Estado e das finanças públicas contemporâneas. Já não se aceitam as boas intenções, e há muito o orçamento deixou de ser simples peça de natureza contábil para se tornar importante instrumento de controle da sociedade sobre a atividade estatal e das finanças públicas ${ }^{150}$.

Em suma, o orçamento começou a ser visto como importante programa de governo, “a lei periódica que contém previsão de receitas e fixação de despesas, programando a vida econômica e financeira do Estado, de cumprimento obrigatório, vinculativa do comportamento do agente público" ${ }^{151}$.

Ainda que sua regulação, em particular no Brasil, tenha enfrentado dificuldades decorrentes de circunstâncias econômicas confusas e desorganizadas em face dos altos índices inflacionários e do total descontrole do Estado sobre os aspectos fundamentais da economia, a ponto de qualificá-lo como um instituto quase inútil e uma peça de ficção, foi mais recentemente que essas preocupações tomaram novos rumos.

É o que se tem notado nos últimos anos. Após superar o momento de maior instabilidade, o orçamento vem se tornando poderoso instrumento de controle e

\footnotetext{
${ }^{149}$ BALEEIRO, Aliomar. Uma introdução à ciência das finanças, p. 398.

${ }^{150}$ OLIVEIRA, Regis Fernandes de. Curso de direito financeiro, p. 369.

${ }^{151}$ Ibidem, p. 366.
} 
planejamento do Estado, ainda que inúmeras questões tenham de ser debatidas, e outras, revistas, conforme será possível observar no decorrer deste estudo.

\subsection{A relevância, na atualidade, do debate da natureza jurídica da lei orçamentária}

A despeito de Álvaro Rodríguez Bereijo ${ }^{152}$ sustentar que a polêmica doutrinária surgida em torno da discussão acerca da natureza jurídica do orçamento se reviste de mero interesse dogmático, não há como olvidar que o debate instaurado em 1871 entre os juristas alemães ainda hoje se mostra pertinente e atual.

Além de necessário para a conclusão a que esta dissertação se propõe, pois esta delineia como um de seus objetivos a análise dos efeitos jurídicos que as "previsões" constantes das leis orçamentárias (art. 165 da CF/1988) são capazes de produzir na ordem econômica, esse debate também se mostra relevante e atual.

Como bem sinalizou José Marcos Domingues de Oliveira, a presente discussão advém da imprescindível promoção de democratização financeira do País, "sem a qual não se descortina verdadeira democracia política, respeitosa à liberdade e à igualdade, sofridas pela pressão fiscal desmedida em razão da má-gestão dos recursos públicos" ${ }^{\text {"153 }}$.

Embora grande parte da doutrina afirme que apenas as leis materiais trazem mandamentos de cunho geral e impessoal, capazes de inovar o ordenamento jurídico, "não se pode negar que o orçamento opera alterações na realidade jurídica, permitindo que sejam os tributos exigidos, colocando em posição de sujeição aqueles que praticam fatos geradores, dando nascimento à obrigação tributária" 154 .

Os questionamentos apresentados mostram-se ainda mais relevantes no cenário político, pois, diretamente associada à discussão da natureza jurídica do orçamento, colocase a questão inerente ao seu caráter autorizativo ou impositivo, a ser tratada com mais

\footnotetext{
${ }^{152}$ BEREIJO, Álvaro Rodríguez. Orçamento - I. Revista de Direito Público, n. 94, p. 18-43.

153 OLIVEIRA, José Marcos Domingues de. O desvio de finalidade das contribuições e o seu controle tributário e orçamentário no direito brasileiro. In: (Coord.). Direito tributário e políticas públicas. São Paulo: MP Editora, 2008. p. 299-347.

${ }^{154}$ OLIVEIRA, Regis Fernandes de. Curso de direito financeiro, p. 367-368.
} 
profundidade na abordagem das questões inerentes à realização de despesas. Afinal, "do ponto de vista político o orçamento do Estado de Direito sempre constituiu forma de controle da Administração, que por seu intermédio fica adstrita à execução das despesas no período e nos limites do planejamento" ${ }^{\text {155. }}$

De toda sorte, embora não se possa concordar com essa posição, prevalece hodiernamente a ideia de que, embora formalmente o orçamento se assemelhe às demais leis (arts. 59 a 69 da CF/1988), ele é considerado mera "lei de meios", ou seja, simples instrumento de arrecadação destinado a fazer frente aos gastos públicos, desprovido de qualquer vinculação ou criação de direitos subjetivos porque não modifica as leis tributárias e nem financeiras, estando adstrito apenas às disposições constitucionais dos arts. 165 a 169 e às demais leis infraconstitucionais a ele relacionadas, como a Lei de Responsabilidade Fiscal (LRF - conhecida como Lei Complementar $n^{\circ}$ 101/2000) e a Lei $\mathrm{n}^{\mathrm{o}} 4.320 / 1964$.

Precursor desse pensamento, Paul Laband sustentava, em 1871, que a aprovação legislativa do orçamento se destinava apenas a tranquilizar os ministros que temiam por sua responsabilidade. As circunstâncias específicas e atinentes à época motivaram essa sua manifestação, a qual se deve mais às instâncias políticas que a qualquer pretensão de cunho científico $^{156}$, tendo se apoiado na concepção dualista da lei ${ }^{157}$. Para o jurista ${ }^{158}$ :

Nem a Constituição do Império, nem a Constituição prussiana contêm indicação sobre os efeitos jurídicos do orçamento legalmente estabelecido. Esses efeitos devem ser deduzidos cientificamente da natureza jurídica do orçamento. Assim aparecem as consequências do princípio segundo o qual o orçamento, embora estabelecido por uma lei, do ponto de vista formal, não é uma lei mais um plano de gestão. O orçamento não contém nenhuma regra jurídica, nenhuma ordem, nenhuma proibição.

\footnotetext{
155 TORRES, Ricardo Lobo. Tratado de direito constitucional, financeiro e tributário: o orçamento na Constituição, p. 66.

${ }^{156}$ Para melhor compreensão dos fatos históricos que motivaram o desenvolvimento do pensamento de Laband, veja-se: BEREIJO, Álvaro Rodríguez. Orçamento - I, II e III. Revista de Direito Público, respectivamente, n. 94, p. 18-43, abr./jun. 1990; n. 95, p. 5-18, jul./set. 1990; e n. 96, p. 5-41. out./dez. 1990.

${ }^{157}$ Laband esclarece que a lei orçamentária se dividia em duas partes distintas: (i) o orçamento propriamente dito; e (ii) a lei que o aprovava.

${ }^{157}$ LAB AND, Paul. Le droit public de l'empire allemand. Paris: Giard \& Brière, 1904. v. VI, p. 268-269.

${ }^{158}$ Ibidem, p. 289.
} 
Giovanni Ingrosso ${ }^{159}$ e Gian Antonio Micheli ${ }^{160}$, dentre outros, sustentam que o orçamento tem natureza material e, portanto, cria direitos e inova no tocante às leis financeiras. Em outros termos:

Pode-se também ver o orçamento como lei em sentido material, em relação às receitas. É que, na previsão dos recursos tributários e das denominadas receitas originárias, há a constante possibilidade de cobrança. A previsão legal não se exaure em uma só previsão, mas sua ação-tipo é repetida ${ }^{161}$.

O orçamento seria dotado, no que se refere às receitas, de caráter geral e abstrato, pois alcança toda a sociedade ou uma classe de pessoas e se identifica pela repetição, sem exaurir a previsão legal ${ }^{162}$.

Os defensores dessa ideia admitem, ainda, que a lei orçamentária é capaz de produzir efeitos subjetivos em relação aos administrados e instituir obrigações à Administração Pública, como destaca Carlos M. Giuliani Fonrouge ${ }^{163}$ :

Puede decirse a manera de conclusión, que el presupuesto es un acto de transcendencia que regula la vida económica y social del país, con significación jurídica y no meramente contable; que es manifestación integral de la legislación, de carácter unitario en su constitución, fuente de derechos y obligaciones para la administración y productor de efectos con relación a los particulares. Como dice Ingrosso, "es una ley de organización, la mayor entre las leyes de organización”. (grifo do original)

É oportuno mencionar, ainda, uma terceira corrente, cujos adeptos, dentre eles Léon Duguit $^{164}$, sustentam que o orçamento não é lei nem material nem formal, mas lei sui generis, dotado de natureza meramente administrativa no que diz respeito à despesa, e lei material quando autoriza a cobrança de tributos.

Nesse contexto, Gaston Jèze ${ }^{165}$ relacionou três teorias que persistem ainda hoje no debate instaurado acerca da natureza jurídica da lei orçamentária. Para os adeptos da

\footnotetext{
${ }^{159}$ INGROSSO, Giovanni. Diritto finanziario. Napoli: Jovene, 1956. p. 55.

${ }^{160}$ MICHELI, Gian Antonio. Corso di diritto tributario. Torino: UTET, 1976. p. 51.

${ }^{161}$ OLIVEIRA, Regis Fernandes de. Curso de direito financeiro, p. 367.

162 Ibidem, p. 367.

${ }^{163}$ FONROUGE, Carlos M. Giuliani. Derecho financiero. 3. ed. Buenos Aires: Depalma, 1977. v. I, p. 143.

164 TORRES, Ricardo Lobo. Tratado de direito constitucional, financeiro e tributário: o orçamento na Constituição, p. 98.

${ }^{165}$ JĖZE, Gaston. Traité de science des finances: le budget... Paris: V. Giard \& Brière, 1910. t. I, p. 49.
} 
primeira teoria, a lei orçamentária traça regras jurídicas e, portanto, seria lei propriamente dita; para os defensores da segunda, o orçamento ora é lei, ora ato da Administração Pública; e, por fim, para os adeptos a terceira, o orçamento jamais poderia ser considerado uma lei.

Gaston Jèze rechaça as três teorias apontadas. Em breve síntese, chega à conclusão de que, no tocante às receitas, a lei orçamentária não seria jamais uma lei propriamente dita e, no tocante às despesas, o orçamento, a depender do tipo de despesas, não teria nenhuma significação jurídica ou, para outro tipo, seria mero ato-condição.

De acordo com Francisco Campos, também “coube a Laband o privilégio de exercer na controvérsia influência decisiva, correspondente à sua indisputável autoridade teórica no campo do direito constitucional alemão"166. O autor esclarece que "a doutrina de Laband consiste em despir o orçamento de qualquer significação jurídica, considerando-o tão somente como um expediente de ordem prática, destinado a pôr ordem na Administração" ${ }^{167}$. E acrescenta:

\begin{abstract}
Assim o orçamento não é um ato de legislação, considerada esta como atividade criadora ou modificadora da ordem jurídica; é um simples ato de administração. Cometendo à representação popular a função de estimar anualmente a receita e a despesa do Estado, a Constituição, abrindo brecha ao princípio da separação dos poderes, se limita a atribuir ao parlamento o direito de participar da Administração e de exercer sôbre ela um contrôle de caráter meramente político. (Laband, Op. e vol. Cits., págs. 268-269) ${ }^{168}$.
\end{abstract}

Mesmo que se afirme tratar-se de mero ato administrativo, sem caráter de lei, ou de lei formal, lei em sentido material e formal, ou, até mesmo, lei em relação à receita e ato administrativo no tocante à despesa ${ }^{169}$; ainda hoje remanescem dúvidas e questionamentos acerca da obrigatoriedade de cumprimento de tudo quanto é estabelecido na lei orçamentária.

As indagações em referência, formuladas por Fernando Sainz de Bujanda muito antes da atual Constituição espanhola (1978), ainda subsistem e revelam a necessidade de

\footnotetext{
${ }^{166}$ CAMPOS, Francisco. Natureza jurídica do orçamento. Revista de Direito Administrativo, n. 71, 1963, p. 324 .

${ }^{167}$ Ibidem, p. 325.

${ }^{168}$ Ibidem, p. 324.

${ }^{169}$ OLIVEIRA, Regis Fernandes de. Curso de direito financeiro, p. 366-367.
} 
se manter aceso o debate acerca da natureza jurídica da lei orçamentária, pois seus reflexos a todo instante têm causado surpresa. Veja-se:

\begin{abstract}
O quê, com efeito, se ventila quando se discute se o Orçamento é uma autêntica lei, em sentido material ou meramente formal, ou um ato-condição ou uma decisão de outra índole? [...] [é] saber se o Orçamento contém normas jurídicas de caráter geral ou se, ao contrário, constitui uma mera autorização do Legislativo ao Governo para que este realize determinadas cobranças e despesas. Agora bem, esta questão não se pode pôr nem se resolver satisfatoriamente sem se indagar previamente o que a aparição do orçamento significou na vida política dos povos. [...] Pouca [ou nenhuma, anota-se] garantia haveria sido, com efeito, a faculdade de as Assembléias aprovarem as previsões financeiras dos Governos, se não se houvessem reservado ao mesmo tempo a faculdade de decidir taxativamente os ingressos e os gastos que o Executivo podia realizar ${ }^{170}$.
\end{abstract}

Admitido como verdadeiro plano de governo, em que os fins da atividade do Estado se voltam à satisfação das necessidades públicas e sua efetiva realização ${ }^{171}$, não há como afastar o fato de que o orçamento vincula substancialmente os diferentes entes e órgãos públicos responsáveis pela sua execução, impondo a necessidade de se atribuir maior responsabilidade a sua elaboração, assim como de dotá-lo de um mínimo de impositividade, sob pena de se manter a pecha de que o orçamento não passa, na realidade, de uma "mera peça de ficção"172.

A propósito, urge lembrar que o próprio Superior Tribunal Federal (STF), embora em diversas ocasiões tenha rejeitado a análise e procedência de ações diretas de inconstitucionalidade (ADIns) ${ }^{173}$ propostas em face de leis orçamentárias, por considerálas leis meramente formais e de efeitos $\operatorname{concretos}^{174}$, também já disse o ministro Ayres

\footnotetext{
${ }^{170}$ BUJANDA, Fernando Sainz de. Hacienda y Derecho. Madrid: Instituto de Estudios Políticos, 1955. p. 323-324.

${ }^{171}$ HORVATH, Estevão; OLIVEIRA, Regis Fernandes de. Manual de direito financeiro. 6. ed. São Paulo: Revista dos Tribunais, 2003. p. 103.

172 OLIVEIRA, Regis Fernandes de. Deve o orçamento ser cumprido? Jus Navegandi, Teresina, ano 9, n. 672, 8 de maio de 2005. Disponível em: <http://jus.com.br/revista/texto/6698/deve-o-orcamento-sercumprido>. Acesso em: 22 abr. 2013.

${ }^{173}$ É pela ação direta de inconstitucionalidade (ADIN) que se dá o controle, pelo Poder Judiciário, da constitucionalidade das normas jurídicas in abstracto.

${ }^{174}$ Nesse sentido: ADI nํㅡㄴ 203 - AgR/DF; rel. Min. Celso de Mello, julg. em 22 de março de 1990, Tribunal Pleno, publ. $D J$ de 20 de abril de 1990; ADI nº 842 - MC/DF, rel. Min. Celso de Mello, julg. em 26 de fevereiro de 1993, Tribunal Pleno, publ. DJ de 14 de maio de 1993; ADI no 1.640-7, rel. Min. Sydney Sanches, julg. 12 de fevereiro de 1998, Tribunal Pleno, publ. DJ de 3 de abril de 1998; ADI no $2057-$ MC/AP, rel. Min. Maurício Corrêa, julg. em 9 de dezembro de 1999, Tribunal Pleno, publ. DJ de 31 de março de 2000, e ADI no 2.925/DF, rel. Min. Ellen Gracie, jug. em 19 de dezembro de 2004, Tribunal Pleno, publ. $D J$ de 4 de março de 2005.
} 
Britto que a lei orçamentária, depois da Constituição Federal, é a mais importante para o País ${ }^{175}$.

Logo, não remanescem dúvidas que a discussão acerca da natureza jurídica da lei orçamentária se mostra atual e sujeita a novas interpretações, pois é do orçamento que os países se valem para realizar seus objetivos, os quais estão sujeitos a mudanças ideológicas, culturais e econômicas, sensivelmente perceptíveis no mundo globalizado.

\subsection{Planejamento e conteúdo da lei orçamentária}

Em face das teorias desenvolvidas acerca da natureza jurídica da lei orçamentária e, uma vez reconhecida como importante programa de governo, pois considerada "a lei periódica que contém previsão de receitas e fixação de despesas, programando a vida econômica e financeira do Estado, de cumprimento obrigatório, vinculativa do comportamento do agente público" ${ }^{176}$, faz-se necessário definir o que se deve compreender por planejamento e como ele se realiza por meio das leis orçamentárias.

\footnotetext{
${ }^{175}$ Voto do ministro Carlos Ayres Britto, proferido nos autos da ADI-MC 4048-1/DF, julgada em 14 de maio de 2008, p. 38: "E, no caso da lei orçamentária - Vossa Excelência disse muito bem -, no fundo, abaixo da Constituição, não há lei mais importante para o país, porque a que mais influencia o destino da coletividade, do que esta lei. A lei orçamentária é a lei materialmente mais importante do ordenamento jurídico logo abaixo da Constituição. E deixar essa lei do lado de fora do controle de constitucionalidade, em processos objetivos, parece um contra-senso realmente." (disponível em: <http://www.stf.jus.br/arquivo/ cms/publicacaoRTJ/anexo/206_1.pdf>. Acesso em: 12 jul. 2012).

${ }^{176}$ OLIVEIRA, Regis Fernandes de. Curso de direito financeiro, p. 366.
} 


\subsubsection{Conceito de planejamento}

De início, apresenta-se o conceito de planejamento proposto por José Afonso da Silva, segundo o qual, trata-se de "um processo técnico instrumentado para transformar a realidade existente no sentido de objetivos previamente estabelecidos" ${ }^{\prime 17}$.

A propósito, a Constituição Federal brasileira traz em diversos dispositivos - v.g., arts. 21, inc. IX; 30, inc. VIII; 43, inc. II; 48, inc. II; 49, inc. IX; 68, § 1ㅜㅜ 74, inc. I; 84, inc. XXIII; $165, \S 7^{\mathrm{o}} ; 174 ;$ e $182, \S 1^{\underline{\mathrm{o}}}-$, a expressa ideia de planejamento como norte condutor da atividade estatal e do desenvolvimento. Afinal, somente por meio de decisões coordenadas e empregando uma atuação ampla e intensa é que o Estado poderá modificar as estruturas socioeconômicas, promover a distribuição e a descentralização da renda e integrar a população, social e politicamente ${ }^{178}$.

Inserem-se nesse cenário as leis orçamentárias e os impactos que estas exercem sobre o domínio econômico, pois, como adverte Heleno Taveira Torres, "ao Estado cumpre realizar a Constituição, nas suas máximas possibilidades, com planejamento e, quando necessário, outras medidas de intervencionismo, inclusive mediante normas de Direito Financeiro" ${ }^{179}$.

Nessa mesma linha é o sentido empregado por Eros Grau, segundo o qual, o planejamento consiste em uma "forma de ação racional caracterizada pela previsão de comportamentos econômicos e sociais futuros, pela formulação explícita de objetivos e pela definição de meios de ação coordenadamente dispostos" ${ }^{\prime 180}$.

Com base nesse entendimento, e tendo em mente o atual papel e concepção que assume o orçamento público perante o Estado e a sociedade, mostra-se este indispensável e fundamental à realização dos desígnios econômicos e sociais do País, notadamente para o cumprimento dos objetivos fundamentais traçados na Constituição Federal de 1988, estabelecidos em vários dispositivos, dentre os quais aqueles constantes do art. $3^{\circ}$, em que

\footnotetext{
177 SILVA, José Afonso da. Curso de direito constitucional positivo, p. 786.

178 BERCOVICI, Gilberto. Constituição econômica e desenvolvimento: uma leitura a partir da Constituição de 1988 , p. 69.

${ }^{179}$ TORRES, Heleno Taveira. Teoria da Constituição financeira. 2013. Tese (Concurso público de títulos e provas para o provimento do cargo de Professor Titular de Direito Financeiro) - Faculdade de Direito da Universidade de São Paulo, 2013, p. 26.

${ }^{180}$ GRAU, Eros Roberto. A ordem econômica na Constituição de 1988, p. 150.
} 
preconiza a busca pela construção de uma sociedade cada vez mais livre, justa e solidária, assim como a erradicação da pobreza, da marginalização e da desigualdade social.

Nessa toada, Gilberto Bercovici esclarece que "o plano é a expressão da política geral do Estado. É mais do que um programa, é um ato de direção política, pois determina a vontade estatal por meio de um conjunto de medidas coordenadas, não podendo limitarse à mera enumeração de reivindicações" 181 .

Diante dos atuais desígnios do Estado e seu agigantamento, nota-se que o planejamento constitui um dos principais instrumentos de que dispõem os governantes para alcançar a almejada eficiência, a qual está intimamente atrelada à ideia de economicidade e controle dos gastos públicos.

\subsubsection{A lei orçamentária como instrumento de planejamento}

Apresentado o conceito de planejamento, verifica-se que, em relação à matéria orçamentária, o legislador constituinte brasileiro reservou aos arts. 165 e seguintes sua exata compreensão ao dispor sobre as finanças públicas, o orçamento e a tributação, estabelecendo, assim, parte de um sistema que compõe o que se denomina "Constituição Financeira", cujo tema foi exaustiva e brilhantemente apresentado por Heleno Taveira Torres, consistindo esta num "modelo fundamental para bem compreender o Direito Financeiro" $^{, 182}$. O autor ${ }^{183}$ sustenta que:

Em verdade, todos os princípios fundamentais da organização do Estado, do sistema tributário, do orçamento público ou dos que regem as despesas, dentre outros, podem ser concebidos como princípios da Constituição financeira. Não há como destacar princípios com maior ou menor importância.

${ }^{181}$ BERCOVICI, Gilberto. Constituição econômica e desenvolvimento: uma leitura a partir da Constituição de 1988, p. 69.

${ }^{182}$ TORRES, Heleno Taveira. Teoria da Constituição financeira, p. 128.

${ }^{183}$ Ibidem, p. 143. 
Do ponto de vista formal, a denominada Constituição Orçamentária, um dos subsistemas da Constituição Financeira, como sugere Ricardo Lobo Torres ${ }^{184}$, não se esgota nos referidos dispositivos constitucionais, abrangendo também as normas sobre o controle da execução orçamentária (arts. 70 a 75), o orçamento do Poder Judiciário (art. 99) e a fiscalização orçamentária dos Municípios (art. 31).

Tal qual o sistema argentino, o sistema brasileiro também não é dotado de uma codificação específica do direito público financeiro. Como relata Horacio Corti ${ }^{185}$, esta constitui uma das características que se revela em matéria financeira, em que a ausência de uma codificação impede o manuseio transparente da coisa pública, dificulta a compreensão dos textos e perturba a previsibilidade da ação estatal, contrariando a segurança jurídica.

No sistema pátrio, basta verificar que, além das disposições constitucionais esparsas, inúmeros outros dispositivos também regulamentam a lei orçamentária, como, v.g., a Lei Complementar $\mathrm{n}^{\mathrm{o}}$ 101, de 4 de maio de 2000 (Lei de Responsabilidade Fiscal), e a Lei no 4.320, de 17 de março de 1964 (lei geral do orçamento), a qual, recepcionada pela Constituição Federal, estabelece, no art. $2^{\underline{0}}$, que a lei orçamentária “conterá a discriminação da receita e despesa de forma a evidenciar a política econômico-financeira e o programa de trabalho do Governo, obedecidos os princípios da unidade, universalidade e anualidade".

José Maurício Conti ${ }^{186}$ esclarece que:

[...] a implementação do planejamento na ação governamental dá-se por meio das leis de natureza orçamentária que, atualmente, com o desenvolvimento das técnicas de orçamento por programas, associadas a sistemas de leis que se vinculam para estabelecer políticas de longo prazo, permitem que se construa um sistema jurídico que dá sustentação ao planejamento da administração pública.

Ainda que se mostre de difícil compreensão, é o que se extrai do art. 165 da CF/1988, o qual estabelece, de modo geral, que o orçamento é estruturado por três leis

\footnotetext{
${ }^{184}$ TORRES, Ricardo Lobo. Curso de direito financeiro e tributário. 18. ed. Rio de Janeiro: Renovar, 2011. p. 171 .

${ }^{185}$ CORTI, Horacio Guillermo. Derecho constitucional presupuestario. 2. ed. Buenos Aires: Abeledo Perrot, 2011. p. 49. No original: "Una de las características del derecho público, que se revela con énfasis en esta materia, es la ausencia de codificación, circunstancia que obstaculiza el manejo transparente de la cosa pública, dificulta la comprensión de los textos y perturba la previsibilidad del accionar estatal. Es decir, la ausencia de codificación es contraria a la seguridad jurídica, que es un rasgo de la forma republicana de gobierno.".

${ }_{186}$ CONTI, José Maurício. Planejamento e responsabilidade fiscal. In: SCAFF, F. F.; CONTI, José Maurício. Lei de Responsabilidade Fiscal. 10 anos de vigência - questões atuais. São Paulo: Conceito, 2010. p. 41.
} 
orçamentárias: (i) o Plano Plurianual (PPA); (ii) as Leis de Diretrizes Orçamentárias (LDO); e (iii) a Lei Orçamentária Anual (LOA), as quais devem estabelecer as diretrizes, objetivos e metas da Administração Pública, bem como suas prioridades, as alterações na legislação tributária e os planos e programas nacionais, regionais e setoriais previstos na Constituição, além do orçamento fiscal referente aos Poderes da União, seus fundos, órgãos e entidades da Administração direta e indireta.

As leis mencionadas, mesmo tendo recebido um tratamento diferenciado, sujeitamse ao disposto no art. 166 da $\mathrm{CF} / 1988$, em especial ao $\S 7^{\circ}$, o qual prevê expressamente que, "aplicam-se aos projetos mencionados neste artigo, no que não contrariar o disposto nesta seção, as demais normas relativas ao processo legislativo".

Com efeito, o processo legislativo orçamentário guarda absoluta identidade com o processo legislativo de elaboração de outras normas, constantes dos arts. 59 a 69, e, embora seja de competência exclusiva do Presidente da República (art. 61, § 1ํㅗ II, b), assim como de sua iniciativa o envio da lei orçamentária (art. 84, XXIII) - todos dispositivos da $\mathrm{CF} / 1988$-, os projetos de lei relativos ao plano plurianual, às diretrizes orçamentárias e ao orçamento anual devem ser apreciados pelas duas Casas do Congresso Nacional, na forma do regimento comum.

Logo, não há distinção entre as leis orçamentárias e as demais leis, ao menos no que se refere ao seu aspecto formal - conforme abordado anteriormente ao tratar da natureza jurídica da lei orçamentária -, as quais fazem parte do processo legislativo ordinário, previsto no inc. III, do art. 59, da CF/1988, estando sujeitas a emendas e ao quórum mínimo previsto no $\S 2^{\underline{0}}$ do art. 61, para, posteriormente, serem submetidas à sanção ou veto do Presidente da República e consequente publicação.

Compete, portanto, às leis orçamentárias a condução da política econômica adotada pelo país e, não por menos, constitui "um poderoso instrumento de intervenção na economia e na sociedade" ${ }^{187}$, cujas realizações práticas serão abordadas nos capítulos subsequentes.

Verdadeiro plano de ação governamental, as leis orçamentárias constituem importante peça de planejamento, por meio da qual o Estado, nas palavras de Ricardo Lobo Torres, institui o denominado "Estado de Planejamento". Veja-se:

${ }^{187}$ OLIVEIRA, Regis Fernandes de. Curso de direito financeiro, p. 366. 
O Estado Orçamentário, que pelo orçamento fixa a receita fiscal e a patrimonial, autoriza a entrega de prestações de educação, saúde, seguridade e transportes e orienta a promoção do desenvolvimento econômico, o equilíbrio da economia e da redistribuição de renda, é um Estado de Planejamento. A receita pública, os investimentos e as despesas se fazem segundo planos anuais ou plurianuais. $\mathrm{O}$ Estado de planejamento não se confunde com o Estado de Planificação, que é sempre manifestação totalitária ou socialista, nem está em vias de extinção, como pretendem os adeptos do pós-modernismo, que vislumbram o desaparecimento dos planos estatais, substituídos pela repartição de responsabilidades financeiras entre o Estado e a Sociedade ${ }^{188}$.

Daí, portanto, a especialidade da lei orçamentária, em que, de acordo com a Constituição Federal brasileira, visa dar efetividade ao princípio do planejamento ou programação ao prever, no art. 165, três planejamentos orçamentários que "se integram harmoniosamente, devendo a lei orçamentária anual respeitar as diretrizes orçamentárias, consonando ambas com o orçamento plurianual (arts. 165, § $7^{\mathrm{o}}, 166, \S 4^{\mathrm{o}}$; e $167, \S 1^{\mathrm{o}}$ )"189, em que a Administração, por intermédio deste, também acaba por exercer uma função regulatória da sociedade, o que as distingue das demais leis, em seu aspecto formal.

Ademais, e ainda que se afirme constituir o orçamento mera peça de autorização à Administração Pública para esta poder executar o programa traçado em leis específicas, não se pode afastar a hipótese de suas previsões causarem impactos na economia.

A mera satisfação da obrigatoriedade de fazer constar na lei orçamentária anual o orçamento fiscal da União, o orçamento de investimento das empresas estatais e o orçamento da seguridade social já basta para denotar que há muito o orçamento deixou de ser apenas uma peça política para se tornar importante instrumento de concretização do plano de governo que envolve toda a economia nacional.

Decorre daí a conclusão a que chegou ao tratar da natureza jurídica da lei orçamentária e, ao olhar adiante, do que se deve extrair do princípio da unidade orçamentária.

\footnotetext{
${ }^{188}$ TORRES, Ricardo Lobo. Tratado de direito constitucional, financeiro e tributário: o orçamento na Constituição, p. 77.

${ }^{189}$ Ibidem, p. 78.
} 
Embora muitos autores se limitem a mencionar a definição proposta por Giuliano Fonrouge $^{190}$ sobre o princípio da unidade e em dizer que este consistiria na reunião e agrupamento de todos os gastos e receitas do Estado em um único documento, mostra-se importante destacar que o referido princípio assume, perante os propósitos do planejamento constitucionalmente inserido, outro significado de suma relevância.

Ao contemplar o princípio da unidade orçamentária e, também, ainda de acordo com Giuliani Fonrouge, a institucionalização do princípio da unidade teria por objetivo: (i) permitir melhor visualização sobre o equilíbrio orçamentário; (ii) dificultar a realização de manobras, como simulação econômica ou ocultação de gastos públicos; (iii) facilitar o controle parlamentar, afastando contas fracionadas; e, ainda, (iv) evitar complicações e obscuridades, tornando a compreensão do orçamento mais fácil e acessível ${ }^{191}$.

Coloca-se a unidade orçamentária, neste contexto, como corolário do equilíbrio e do planejamento, verificando-se que, além destes, a Constituição Federal brasileira traz em seu corpo uma série de outros princípios e dispositivos que estão diretamente ligados ao caráter gerencial da gestão pública. É o que demonstra Gilberto Bercovici ${ }^{192}$ ao tratar da importância do princípio da unidade:

\begin{abstract}
A unidade do orçamento era outro princípio clássico. Todas as contas orçamentárias deveriam constar de um único documento e de uma única caixa, de modo a fazer com que as despesas e receitas convergissem para um fundo geral, evitando-se as vinculações de certos fundos a fins específicos. Dessa maneira, seria suficiente fazer contas simples para a obtenção do total das despesas e do total das receitas e para se saber se há déficit, equilíbrio ou superávit. O objetivo desse princípio era o de facilitar o controle político das finanças.
\end{abstract}

Exige-se, em observância ao disposto no texto constitucional ${ }^{193}$, uma Administração proba, eficiente e eficaz, o que se pode notar da previsão expressa da

\footnotetext{
${ }^{190}$ No original: "el principio de unidad presupuestaria consiste en la reunión o agrupación de todos los gastos y recursos del Estado en un documento único" (FONROUGE, Carlos M. Giuliano. Derecho financiero, p. 167).

${ }_{191}^{191}$ FONROUGE, Carlos M. Giuliano. Derecho financiero, p. 167 e ss.

${ }^{192}$ BERCOVICI, Gilberto. Os princípios orçamentários e a primeira Constituição republicana. Revista de Direito Internacional e Econômico, Porto Alegre, v. 1, n. 1, out./dez. 2002, p. 81.

${ }^{193}$ De acordo com Bercovici, "a experiência brasileira de planejamento antes da Constituição de 1988 é marcada por três grandes momentos, dos quais apenas um foi uma experiência bem-sucedida. Estes momentos são representados pelo Plano de Metas (1956-1961), pelo Plano Trienal (1962-1963) e pelo II Plano Nacional de Desenvolvimento (1975-1979)" (idem. O planejamento e a Constituição de 1988. In: SCAFF, Fernando Facury (Coord.). Constitucionalizando direitos: 15 anos da constituição brasileira de 1988. Rio de Janeiro: Renovar, 2003. p. 308).
} 
avaliação do cumprimento das metas orçamentárias, da avaliação dos resultados da gestão no tocante à eficiência e eficácia, ao instituir princípios como o da economicidade ${ }^{194} \mathrm{e}$ impor a obrigatoriedade de qualquer pessoa, física ou jurídica, pública ou privada, prestar contas dos valores e bens percebidos da União (art. 70, caput, I e II, da CF/1988).

Além disso, a interação do orçamento público com outros sistemas, em especial o econômico e o social, também denuncia o planejamento como sendo uma de suas principais vertentes, a qual decorre de toda a ideia norteadora do sistema econômicofinanceiro, engendrado pela Constituição Federal de 1988, no qual se encaixam os conceitos anteriormente apresentados.

É o que demonstra o dispositivo da CF/1988, ao preconizar:

Art. 174. Como agente normativo e regulador da atividade econômica, o Estado exercerá, na forma da lei, as funções de fiscalização, incentivo e planejamento, sendo este determinante para o setor público e indicativo para o setor privado. (sem grifo no original)

$\S 1^{0}$. A lei estabelecerá as diretrizes e bases do planejamento do desenvolvimento nacional equilibrado, o qual incorporará e compatibilizará os planos nacionais e regionais de desenvolvimento.

Determinante para o setor público e indicativo para o setor privado, é por intermédio do planejamento, dentre os quais o orçamentário, que as soluções de conflitos sociais e a satisfação de outros objetivos, como o desenvolvimento econômico, a busca pelo pleno emprego, a erradicação da pobreza, o saneamento da saúde pública, da seguridade social etc., são concretizadas.

Tudo em prol do que se denominou federalismo cooperativo, que se traduz em uma estrutura pautada, ao menos do ponto de vista fiscal, pela cooperação entre as entidades federativas, e que "se desenvolve em virtude da necessidade de solidariedade federal por meio de políticas conjuntas e de compensação das disparidades regionais" 195 .

Conclusão similar é a expressa por José Afonso da Silva, segundo o qual, "um orçamento, na concepção moderna e segundo o direito brasileiro atual, não passa do

${ }^{194}$ BRESSER-PEREIRA, Luiz Carlos. Da administração pública burocrática à gerencial. In: BRESSER PEREIRA, Luiz Carlos; SPINK, Peter Kevin. Reforma do estado e administração pública gerencial. 6. ed. Rio de Janeiro: FGV, 2005. p. 242-243.

195 BERCOVICI, Gilberto. Dilemas do estado federal brasileiro. Porto Alegre: Livraria do Advogado, 2004b. p. $58-59$. 
equivalente financeiro do plano de ação governamental" ${ }^{196}$, ou, como prefere Estevão Horvath: "sob qualquer de suas feições, constitui-se no plano do governo juridicizado" 197.

Com efeito, não há como afastar a ideia de que o orçamento público, regido pelos princípios constitucionais, constitua verdadeiro instrumento de planejamento do Estado. Basta lembrar que o orçamento federal, excetuados Estados e Municípios, contempla proposta que supera o montante de $\mathrm{R} \$ 2$ trilhões, ou seja, quase metade da riqueza nacional, como aponta os parâmetros macroeconômicos do Ministério da Fazenda para o exercício de 2014, cuja previsão é de um PIB de, aproximadamente, R \$ 5,24 trilhões.

Urge lembrar que há muito o sistema orçamentário nacional, com a edição da Lei $\mathrm{n}^{\mathrm{o}}$ 4.320/1964, adota a classificação funcional programática, ou funcional e programática como preferem as Portarias STN nos 42 e 163, o que determina um importante passo já consolidado para adoção de padrões de eficiência no orçamento. Para serem alcançados, esses padrões de eficiência dependem de evidente ação planejada.

Destinada à realização de políticas de curto e longo prazos, a ação planejada em referência somente se torna possível diante da vinculação entre as três leis que compõem o sistema orçamentário, ou seja, a Lei de Diretrizes Orçamentárias (LDO), o Plano Plurianual (PPA) e Lei Orçamentária Anual (LOA), como será demonstrado a seguir. Afinal, como reconhece Gilberto Bercovici ${ }^{198}$ :

\begin{abstract}
O modelo de planejamento previsto na Constituição de 1988 visa à instituição de um sistema de planejamento com grande participação do Poder Legislativo e vinculação do plano ao orçamento e aos fins enunciados no texto constitucional. Neste, estão estipuladas as bases para um planejamento democrático, com aumento da transparência e controle sobre o gasto público, ao exigir coerência entre o gasto anual do governo e o planejamento de médio e longo prazos.
\end{abstract}

É cristalino, portanto, que a Constituição concebeu uma estrutura orçamentária pautada no planejamento, a qual, e ao menos no papel, deveria ser determinante para o setor público e indicativo para o setor privado, ainda que esta, consubstanciada nas leis

\footnotetext{
${ }^{196}$ SILVA, José Afonso da. Orçamento programa no Brasil, p. 72.

197 HORVATH, Estevão. Orçamento público e planejamento. In: MELLO, Celso Antônio Bandeira de (Org.). Estudos em homenagem a Geraldo Ataliba - direito tributário. São Paulo: Malheiros, 1997. p. 131.

198 BERCOVICI, Gilberto. Constituição econômica e desenvolvimento: uma leitura a partir da Constituição de 1988, p. 76-77.
} 
orçamentárias, trate de mera autorização para que a Administração execute o programa nelas traçado, a depender da realização das receitas e da economia ${ }^{199}$.

Em outras palavras, a ação planejada do Estado traduz-se pelos conjuntos de leis orçamentárias - PPA, LDO e LOA -, resultando dessa inter-relação políticas de curto e longo $\operatorname{prazos}^{200}$. Para melhor evidenciar o que se acaba de afirmar, passa-se a especificar, a seguir, cada uma dessas políticas.

\subsubsection{O plano plurianual}

A ideia de planejamento se materializa, efetivamente, com o plano plurianual, pois este é um documento legal por meio do qual o Estado planeja e estabelece, de modo prospectivo, os gastos e os investimentos governamentais de médio e longo prazos ${ }^{201}$.

Nos termos do $\S 1^{\underline{o}}$, do art. 165 da $\mathrm{CF} / 1988$, compete à lei que instituir o plano plurianual estabelecer, "de forma regionalizada, as diretrizes, objetivos e metas da administração pública federal para as despesas de capital e outras delas decorrentes e para as relativas aos programas de duração continuada".

Em outras palavras, nesse plano "estará [deverá estar] consubstanciado o plano de governo para quatro anos; é o plano plurianual o plano de governo juridicizado"202.

Nos dizeres de Ricardo Lobo Torres ${ }^{203}$ :

O plano plurianual tem por objetivo estabelecer os programas e as metas governamentais de longo prazo. É planejamento conjuntural para a promoção do

\footnotetext{
199 TORRES, Ricardo Lobo. Tratado de direito constitucional financeiro e tributário: o orçamento na Constituição, p. 78.

${ }^{200}$ CONTI, José Maurício. Planejamento e responsabilidade fiscal. In: SCAFF, F. F.; CONTI, José Maurício. Lei de Responsabilidade Fiscal. 10 anos de vigência - questões atuais, p. 40.

${ }^{201}$ BENETON, Marco Antonio Hatem. O plano plurianual, os contratos administrativos e a teoria do diálogo das fontes: os exemplos de elos entre o direito financeiro e o direito administrativo. In: SCAFF, F. F.; CONTI, José Maurício. Orçamentos públicos e direito. São Paulo: Revista dos Tribunais, 2011. p. 601-617.

${ }^{202}$ HORVATH, Estevão. O orçamento no século XXI: tendências e expectativas. 2014. Tese (Concurso de Professor Titular de Direito Financeiro) - Faculdade de Direito da Universidade de São Paulo, São Paulo, 2014. p. 295.

${ }^{203}$ TORRES, Ricardo Lobo. Op. cit., p. 79.
} 
desenvolvimento econômico, do equilíbrio entre as diversas regiões do País e da estabilidade econômica.

Compete, assim, à Lei Complementar referida no art. 165, § 9º , da CF/1988 dispor sobre o exercício financeiro, a vigência, os prazos, a elaboração e a organização do plano plurianual e, até que esta sobrevenha, aplicar-se-á o disposto no art. $35, \S 2^{\underline{o}}$, inc. I, do Ato das Disposições Constitucionais Transitórias (ADCT) ${ }^{204}$, segundo o qual, “o projeto do plano plurianual, para vigência até o final do primeiro exercício financeiro do mandato presidencial subsequente, será encaminhado até quatro meses antes do encerramento do primeiro exercício financeiro e devolvido para sanção até o encerramento da sessão legislativa".

Quer-se dizer com isso que, embora a Constituição Federal brasileira não fixe prazo de vigência para o plano governamental, o Presidente do País detém, no primeiro ano de seu mandato, a incumbência de remeter o projeto de lei no qual estabelece as propostas de realização para o período de seu governo ${ }^{205}$.

Na prática, o plano plurianual deve contemplar as despesas de capital, ou seja, os investimentos, as inversões financeiras e as transferências de capital (art. 12 da Lei $\mathrm{n}^{\mathbf{0}}$ 4.320/1964), ressaltando-se que:

(i) os investimentos constituem "as dotações para o planejamento e a execução de obras" incluindo aquelas "destinadas à aquisição de imóveis considerados necessários à realização destas últimas”, e, também, “para os programas especiais de trabalho, aquisição de instalações, equipamentos e material permanente e constituição ou aumento do capital de empresas que não sejam de caráter comercial ou financeiro" (art. 12, $\S 4^{\underline{0}}$, da Lei $\left.n^{-0} 4.320 / 1964\right)$;

(ii) as inversões financeiras destinam-se à: (a) aquisição de imóveis, ou de bens de capital já em utilização; (b) aquisição de títulos representativos do capital de empresas ou entidades de qualquer espécie, já constituídas, quando a operação não importe aumento do capital; e (c) constituição ou aumento do capital de

\footnotetext{
${ }^{204}$ TORRES, Ricardo Lobo. Tratado de direito constitucional financeiro e tributário: o orçamento na Constituição, p. 80.

205 Ibidem, p. 80.
} 
entidades ou empresas que visem a objetivos comerciais ou financeiros, inclusive operações bancárias ou de seguros (art. 12, § 5º da Lei 4.320/1964); e

(iii) as transferências de capital são "as dotações para investimentos ou inversões financeiras que outras pessoas de direito público ou privado devam realizar, independentemente de contraprestação direta em bens ou serviços", consistindo essas transferências em "auxílios ou contribuições, segundo derivem diretamente da Lei de Orçamento ou de lei especialmente anterior, bem como as dotações para amortização da dívida pública" (art. 12, § 6º, da Lei nº 4.320/1964).

Em razão de ser o definidor do planejamento das atividades governamentais ${ }^{206}$, ao plano plurianual devem guardar consonância os planos e programas regionais e setoriais previstos na Constituição Federal (art. 165, § 4º ), os quais são instituídos por leis ordinárias e, em geral, vigoram pelo período de quatro anos, consistindo em verdadeiros vetores dos desígnios do Estado ou, como asseverado anteriormente, representam - ou ao menos deveriam representar - os planos daqueles que o governam.

Com efeito, é por meio do PPA que se inicia o ciclo orçamentário, que se estabelecem as diretrizes, estratégias, objetivos e programas da ação governamental, devendo esse plano, no que se refere "às metas, voltar-se à quantificação física e à obtenção de resultados compatíveis com a dinâmica do planejamento, sendo estimados os valores que projeta, não sendo limitadores das despesas futuras" 207.

Nessa esteira, José Afonso da Silva ${ }^{208}$, ao tratar do orçamento-programa, do qual constitui o PPA evidente desdobramento, bem assinala:

Trata-se de planejamento estrutural, porque todos os planos e programas têm suas estruturas estabelecidas segundo o plano plurianual (art. $165, \S 4^{\circ}$ ). Essa "integração do orçamento público com o econômico [como anota Alejandro Ramirez Cardona] garante a necessária coordenação entre a política fiscal (intervencionismo indireto) e a política econômica (intervencionismo direto). Em realidade, assim como a política fiscal é parte da política econômica, igualmente o plano financeiro do Estado deve fazer parte do plano econômico do País. E, por outro lado, já que o equilíbrio financeiro nas finanças modernas se há de estabelecer em relação ao equilíbrio econômico geral, aquela integração é absolutamente indispensável”. Essa integração, agora bem caracterizada na

\footnotetext{
${ }^{206}$ OLIVEIRA, Regis Fernandes de. Curso direito financeiro, p. 386.

${ }^{207}$ BENETON, Marco Antonio Hatem. O plano plurianual, os contratos administrativos e a teoria do diálogo das fontes: os exemplos de elos entre o direito financeiro e o direito administrativo. In: SCAFF, F. F.; CONTI, José Maurício. Orçamentos públicos e direito, p. 606.

${ }^{208}$ SILVA, José Afonso da. Curso de direito constitucional positivo, p. 715
} 
sistemática orçamentária da Constituição, é que dá configuração à concepção de orçamento-programa.

Ao retratar os interesses e objetivos do Estado, especificando ou ao menos indicando como e em que condições serão feitos os investimentos dos recursos públicos, ou seja, como ocorrerá a realização das despesas de capital, o plano plurianual acaba por induzir a iniciativa privada na condução de suas atividades, mesmo que dependa do orçamento anual para ter eficácia quanto à realização das despesas.

É importante observar que "Nenhum investimento cuja execução ultrapasse um exercício financeiro poderá ser iniciado sem prévia inclusão no plano plurianual, ou sem lei que autorize a inclusão" (art. 167, § $1^{\stackrel{0}{ },}$ da CF/1988).

Existe, portanto, a obrigatoriedade de previsibilidade de investimentos que ultrapassem vários exercícios financeiros.

De todo modo, ao tomar conhecimento dos objetivos do Estado em realizar, v.g., obras de infraestrutura - rodovias, aeroportos, portos, ferrovias etc. - , a iniciativa privada, ainda que reconheça constituir o PPA mero programa ou orientação, e desde que dotada de certa credibilidade em sua elaboração, passaria a investir em capacitação técnica, contratação de mão de obra especializada, aquisição de máquinas e equipamentos etc., à espera de que, dentro dos prazos e nas condições estabelecidas no plano, o Estado efetue os investimentos sinalizados.

Ainda que este seja o desejo de uma realidade que se mostra distante, mas, em construção ${ }^{209}$, como apontam os fatos históricos que ensejaram a mudança da concepção e dos objetivos da peça orçamentária, e ainda que o PPA deva ser respeitado pelo Executivo na execução dos orçamentos anuais, mesmo que não esteja o Legislativo a ele vinculado na oportunidade da elaboração e aprovação das leis orçamentárias ${ }^{210}$, falta, tanto quanto às demais leis orçamentárias, atribuir-lhe maior respeito, vinculação e obrigatoriedade de cumprimento.

\footnotetext{
${ }^{209}$ Conforme salienta TORRES, Ricardo Lobo. Tratado de direito constitucional financeiro e tributário: o orçamento na Constituição, p. 82-85. O autor faz um breve escorço histórico acerca de algumas alterações realizadas pela Lei de Responsabilidade Fiscal ao plano plurianual e outras que, embora tenham se mostrado relevantes, "não chegaram a incrementar o desenvolvimento econômico nacional. [...] Quer dizer: houve o esvaziamento da capacidade de investir do Tesouro e o desestímulo e a insegurança para os investimentos privados" (ibidem, p. 84).

${ }^{210}$ Ibidem, p. 83.
} 
A assertiva é corroborada por James Giacomoni, ao destacar que a lei orçamentária, ao longo de sua evolução histórica, deixou de servir como mero controle político para se tornar um instrumento de administração ${ }^{211}$, não mais podendo tolerar que estes sejam elaborados apenas "porque têm de sê-lo" e "de tão genéricos que costumam ser", acabem "por contemplar tudo e nada ao mesmo tempo",212.

Muitos, no entanto, se opõem a essa pretensão, alegando que as consequências decorrentes de uma maior vinculação ou obrigatoriedade de cumprimento, implicaria sua inexecução em caso de não serem realizadas as receitas previstas na lei orçamentária anual. Esses opositores questionam, ainda, se seria possível alterar o PPA durante a fluência de seus efeitos.

As indagações e dúvidas suscitadas já foram respondidas por Regis Fernandes de Oliveira $^{213}$, segundo o qual:

\begin{abstract}
Se alteradas forem as circunstâncias econômicas e sociais do Estado, nada impede que haja mudança no Plano. Este não é estático, mas dinâmico, objetivando alcançar as novas realidades. Cabe, pois, por novo projeto, encaminhar as mudanças que forem imprescindíveis, com adaptação dos novos rumos do país.
\end{abstract}

Logo, o que não se pode mais aceitar é que a elaboração e o cumprimento de um plano de tamanha relevância e importância continuem se dando sem qualquer compromisso com os desígnios do Estado, ao arrepio da norma e em total dissonância com os desejos da população. O plano plurianual é o vetor do planejamento orçamentário pelo período de quatro anos que tem, dentre outros, dois pontos sobressalentes: (i) o direcionamento planejado das despesas, principalmente as de capital ou investimentos sob a égide de metas; e (ii) a vinculação das leis orçamentárias anuais (LDO e LOA) à realização das metas que estabelecidas ${ }^{214}$.

Torna-se necessário cobrar mais responsabilidade e ética daqueles que estão incumbidos de elaborar e executar o PPA, não mais podendo admitir-se, como adverte José

\footnotetext{
${ }^{211}$ GIACOMONI, James. O orçamento público. 14. ed. São Paulo: Atlas, 2007. p. 170.

${ }^{212}$ HORVATH, Estevão. O orçamento no século XXI: tendências e expectativas, p. 296.

${ }^{213}$ OLIVEIRA, Regis Fernandes de. Curso direito financeiro, p. 387.

${ }^{214}$ BENETON, Marco Antonio Hatem. O plano plurianual, os contratos administrativos e a teoria do diálogo das fontes: os exemplos de elos entre o direito financeiro e o direito administrativo. In: SCAFF, F. F.; CONTI, José Maurício. Orçamentos públicos e direito, p. 607.
} 
Maurício Conti ao aludir aos planos plurianuais municipais, que estes sejam "elaborados com base em modelos que se repetem ano a ano, sem uma efetiva preocupação dos prefeitos de neles incorporarem as previsões para o que se vai fazer no decorrer do mandato" 215 .

\subsubsection{As diretrizes orçamentárias}

No tocante à lei de diretrizes orçamentárias, verifica-se que os propósitos do planejamento subsistem, conforme dispõe o $\S 2^{\circ}$, do art. 165 , da CF/1988, ao estabelecer que:

[...] a lei de diretrizes orçamentárias compreenderá as metas e prioridades da administração pública federal, incluindo as despesas de capital para o exercício financeiro subsequente, orientará a elaboração da lei orçamentária anual, disporá sobre as alterações na legislação tributária e estabelecerá a política de aplicação das agências financeiras oficiais de fomento.

Não obstante, Carlos Otávio de Almeida ${ }^{216}$ pondera:

Como a aproximação entre os objetivos do PPA e os efetivos custos para realizalos são de difícil estimativa, a LDO faz o elo entre o PPA e a LOA, compreendendo, basicamente, as metas e prioridades da administração pública federal, incluindo as despesas de capital, para o exercício financeiro subsequente, vindo, desta forma, a orientar a elaboração da LOA. Na prática, deve a LDO dividir as metas fixadas no PPA para a sua concretização anual, confrontando disponibilidade de recursos com prioridades.

Inspirada nas Constituições alemã e francesa, como relata Ricardo Lobo Torres $^{217}$, a lei de diretrizes orçamentárias tem natureza formal e, como o próprio

215 CONTI, José Maurício. Planejamento municipal precisa ser levado a sério. Consultor Jurídico, 24 set. 2013. Disponível em: <http://www.conjur.com.br/2013-set-24/contas-vista-planejamento-municipal-levadoserio>. Acesso em: 8 out. 2014.

216 ALMEIDA, Carlos Otávio Ferreira de. O planejamento financeiro responsável: boa governança e desenvolvimento do Estado contemporâneo. In: CONTI, José Mauricio; SCAFF, Fernando Facury (Coords.). Orçamentos públicos e direito financeiro. São Paulo: Revista dos Tribunais, 2011. p. 583.

${ }^{217}$ TORRES, Ricardo Lobo. Curso de direito financeiro e tributário: o orçamento na Constituição, p. 174. 
orçamento anual, deve ser elaborada no primeiro semestre de cada exercício fiscal (art. 35, II, do ADCT).

A propósito de sua vinculação e obrigatoriedade, o referido autor ${ }^{218}$ conclui:

Da mesma forma que o plano plurianual, não vincula o Congresso Nacional quanto à elaboração da lei orçamentária, nem o obriga, se contiver dispositivos sobre alterações da lei tributária, a alterá-la efetivamente, nem o impede, no caso contrário, de instituir novas incidências fiscais [...].

Nesse aspecto, é pertinente mencionar que o presente estudo não comunga dessa posição pelas mesmas razões já apresentadas anteriormente. Entende-se que a LDO, assim como o PPA, vincula o Congresso Nacional no tocante à elaboração da lei orçamentária, ainda que não implique a obrigação deste alterar a lei tributária. Afinal, a lei de diretrizes orçamentárias constitui um plano prévio, cuja elaboração se dá - ou, pelo menos, deveria dar-se - com fundamento em dados econômicos e sociais e, assim, fornece elementos e dados concretos que o Legislativo deve observar em momento ulterior, ao elaborar a proposta orçamentária.

Além da incumbência constitucional de traçar as regras gerais a serem observadas na elaboração do plano plurianual e dos orçamentos anuais, é importante destacar que a Lei de Responsabilidade Fiscal (Lei Complementar n⿳ํㅗ 101/2000), no art. 4º inc. I, alínea $a$, também passou a exigir que esta disponha sobre o "equilíbrio entre receita e despesas", deixando-se, com isso, de aceitar que sua elaboração se dê sem qualquer compromisso, como esclarece Regis Fernandes de Oliveira ${ }^{219}$ :

\footnotetext{
É verdade que o equilíbrio orçamentário, visto por alguns como princípio, deve ser real. Não mais se pode supor o equilíbrio formal, de maneira a servir de base a "maquiar" a receita e buscar novas operações junto ao Senado Federal, que impõe exigências para endividamento em relação ao produto da receita. $\mathrm{O}$ legislativo também poderá ser envolvido em qualquer disfarce para iludir outros órgãos se não examinar com profundidade os valores que lhe são encaminhados. A tarefa do Legislativo não deve ser vista, também, como mera formalidade à aprovação do orçamento: deve ele esmiuçar a proposta, estudá-la, uma vez que se cuida de projeção futura, mas deve alicerçar-se em dados concretos e factíveis.
}

\footnotetext{
218 TORRES, Ricardo Lobo. Tratado de direito constitucional financeiro e tributário: o orçamento na Constituição, p. 86-87.

${ }^{219}$ OLIVEIRA, Regis Fernandes de. Curso direito financeiro, p. 388-389.
} 
O presente estudo se coaduna, desse modo e dentre outros, com a posição de Estevão Horvath $^{220}$, e, no tocante ao posicionamento de Ricardo Lobo Torres ${ }^{221}$, anui tão somente quando o autor alega que o Legislativo não está obrigado a alterar a legislação tributária, nem impedido de instituir novas incidências fiscais, ainda que assim preveja a LDO, atribuindo-lhe, somente quanto a este aspecto, o caráter de orientação ou de sinalização.

A propósito, Estevão Horvath ${ }^{222}$ elucida:

No que se refere a "orientar a elaboração da lei orçamentária anual" e "estabelecer a política de aplicação das agências financeiras oficiais de fomento", é função sua, constitucionalmente prevista, e o que ficar decidido nessa "orientação" para a elaboração do orçamento e sobre a "política de aplicação das agências financeiras oficiais de fomento" deve ser respeitado até mesmo pelo Legislativo ao apreciar a lei orçamento anual.

Caso contrário, tornar-se-ia letra morta a incumbência que lhe foi atribuída pela Lei de Responsabilidade Fiscal, não só aquela antes mencionada, constante do inc. I, alínea $a$, do art. $4^{\underline{0}}$, mas, também, a obrigação de: (i) dispor sobre limitação de empenho, constante da alínea $b$, cuja obrigação de pagamento pelo Poder Público decorra da lei ou do contrato; (ii) estabelecer "normas relativas ao controle de custos e à avaliação dos resultados dos programas financiados com recursos dos orçamentos", nos termos da alínea $e$ do mesmo dispositivo legal; e, ainda, (iii) dispor sobre as "condições e exigências para transferências de recursos a entidades públicas e privadas", incluída na alínea $f$ do mesmo art. $4^{\circ}$, inc. I.

É importante lembrar que a limitação de empenho não constitui uma inovação introduzida pela Lei de Responsabilidade Fiscal. Como assevera Weder de Oliveira ${ }^{223}$, o conceito de limitação de empenho constitui "expressão técnica que representa o mesmo procedimento que no jargão orçamentário é denominado de "contingenciamento"”, a qual "é promovida por decreto presidencial" e consiste em "procedimento usual na administração federal desde, pelo menos, final dos anos 1980”.

\footnotetext{
${ }^{220}$ HORVATH, Estevão. O orçamento no século XXI: tendências e expectativas, p. 304.

${ }^{221}$ Nesse aspecto, Ricardo Lobo Torres adverte que sua posição "não é unânime, havendo outros autores que atribuem ao plano orçamentário eficácia material, tanto que absorvido pela lei orçamentária" (TORRES, Ricardo Lobo. Tratado de direito constitucional financeiro e tributário: o orçamento na Constituição, p. 86). ${ }^{222}$ HORVATH, Estevão. Op. cit., p. 304-305.

${ }^{223}$ OLIVEIRA, Weder de. Curso de responsabilidade fiscal: direito, orçamento e finanças públicas. Belo Horizonte: Fórum, 2013. p. 404.
} 
Essa limitação somente poderá ser efetuada "se verificado, ao final de um bimestre, que a realização da receita poderá não comportar o cumprimento das metas de resultado primário ou nominal estabelecidas no Anexo de Metas Fiscais" (art. 9ํํㅁ da LRF), ou quando "a dívida consolidada de um ente da Federação ultrapassar o respectivo limite ao final de um quadrimestre, deverá ser a ele reconduzida até o término dos três subsequentes" (art. 31, § 1ํㅡㄴ, II, da LRF).

No que tange à transferência de recursos a entidades públicas e privadas, a Lei de Responsabilidade Fiscal estabelece normas básicas e remete à LDO a função de estabelecer normas complementares e, portanto, reconhece sua função disciplinadora ${ }^{224}$.

Com isso, verifica-se que o Congresso deve, obrigatoriamente, obedecer à LDO, pois fixa "parâmetros para o administrador, no sentido de que existam créditos para os custos que serão assumidos", prevê "critérios para aferição de resultados de programas financiados com recursos orçamentários" e, ainda, permite a "transferência de recursos que são públicos, o ente deve estabelecer quais requisitos exige para a remessa e, inclusive, suas finalidades" 225 .

Além da atribuição de dizer como será feito o orçamento anual, a LDO deve retirar do plano plurianual a parcela das metas e prioridades a serem realizadas no exercício financeiro subsequente. Para tanto, o $\S 1^{\circ}$, do art. $4^{\circ}$, da LRF exige a apresentação de um "Anexo de Metas Fiscais"; ou seja, que sejam "as metas definitivamente estabelecidas", devendo "fixar as receitas e despesas, resultados nominal e primário e montante da dívida pública, para o exercício a que se referirem e para os dois seguintes" 226 .

Urge esclarecer, desse modo, que o resultado primário é obtido da diferença entre receita e despesa, excluídos os juros e o principal da dívida, tanto pagos como recebidos, e o resultado nominal, por sua vez, da diferença de todas as receitas e despesas. “Assim, para a obtenção do resultado primário, apura-se o quanto ingressou de receita, a qualquer título, e abatem-se eventuais operações de crédito, restos a pagar, receitas obtidas com aplicações financeiras e despesas empenhadas" 227 .

\footnotetext{
${ }^{224}$ OLIVEIRA, Weder de. Curso de responsabilidade fiscal: direito, orçamento e finanças públicas, p. 526.

${ }^{225}$ OLIVEIRA, Regis Fernandes de. Curso direito financeiro, p. 389-390.

226 Ibidem, p. 390.

${ }^{227}$ Ibidem, loc. cit.
} 
Mais ainda, referido Anexo, nos termos do $\S 2^{\circ}$, do art. $4^{\circ}$, da LRF, deve conter: (i) a "avaliação do cumprimento das metas relativas ao ano anterior" (inc. I), a qual deve ser apresentada com dados objetivos a fim de fundamentar qualquer análise; (ii) "demonstrativo das metas anuais, instruído com memória e metodologia de cálculo que justifiquem os resultados pretendidos, comparando-as com as fixadas nos três exercícios anteriores" (inc. II); e (iii) "a evolução do patrimônio líquido, também nos três últimos exercícios, destacando a origem e a aplicação dos recursos obtidos com a alienação de ativos" (inc. III).

Além dos dados mencionados, o Anexo em questão também deve apresentar todos os dados de modo objetivo a fim de permitir a análise do Legislativo sobre "a avaliação da situação financeira e atuarial dos regimes geral de previdência social e próprio dos servidores públicos e do Fundo de Amparo ao Trabalhador", bem como "dos demais fundos públicos e programas estatais" (art. $4^{\underline{o}}, \S 2^{\underline{o}}, \mathrm{IV}, a$ e $b$, da LRF).

Impõe-se, ainda, que o Anexo contenha o "demonstrativo da estimativa e compensação da renúncia de receita e da margem de expansão das despesas obrigatórias de caráter continuado" (art. $4^{\underline{o}}, \S 2^{\underline{o}}, \mathrm{~V}$, da LRF), a qual "diz respeito, por exemplo, a nomeações de servidores, elevação de padrão, progressividade funcional, aumento de vencimentos, reestruturação de planos de carreira. Tudo deriva de lei e sujeita o Poder Público a seu pagamento" 228 .

Por último, vale destacar que a LDO deve, de acordo com o disposto nos $\S \S 3^{\circ} \mathrm{e}$ $4^{\mathrm{O}}$, do art. $4^{\mathrm{O}}$ da LRF, respectivamente, informar outro Anexo, de Riscos Fiscais, "onde serão avaliados os passivos contingentes e outros riscos capazes de afetar as contas públicas, informando as providências a serem tomadas, caso se concretizem" e estabelecer "os objetivos das políticas monetárias, creditícia e cambial, bem como os parâmetros e as projeções para seus principais agregados e variáveis, e ainda as metas de inflação, para o exercício subsequente".

Diante de tudo quanto foi apontado, fica nítida a importância da LDO como instrumento de planejamento e de orientação à iniciativa privada, cuja obrigatoriedade de observação se impõe em diversos outros dispositivos constitucionais, dentre os quais, os arts. 51, inc. IV; 52, inc. XIII; 99, $\S 1^{\mathrm{o}}$ e $4^{\mathrm{o}}$; e $127, \S \S 3^{\mathrm{o}}$ e $5^{\mathrm{o}^{\circ}}$.

\footnotetext{
${ }^{228}$ OLIVEIRA, Regis Fernandes de. Curso direito financeiro, p. 391.
} 
Ressalte-se, a título meramente ilustrativo, anotação feita por Ricardo Lobo Torres relatando que, na França, o advento da Lei Orgânica $n^{\circ}$ 2001-692, de $1^{\circ}$ de agosto de 2001, aplicada pela primeira vez à lei de finanças de 2006, importou na mudança da própria filosofia orçamentária até então adotada, ao ponto de transformar "o orçamento de peça formal organizada pela natureza da despesa em lei finalística, com a procura de resultados e performance" 229 .

No Brasil, ao contrário, a prática legislativa tem demonstrado pouco ou quase nenhum respeito à LDO no que toca ao planejamento financeiro do Estado, servindo apenas para consolidar o injustificável alargamento da competência do Legislativo e causar grandes danos à ordem financeira, como apontou a Comissão Parlamentar de Inquérito aberta em 1993, intitulada de "CPI dos Anões do Orçamento"230, além de implicar o atraso da aprovação dos orçamentos, como vivenciado, de maneira mais significativa, nos exercícios de 1993 e $1994^{231}$.

\subsubsection{O orçamento anual}

Trata-se, por fim, da lei orçamentária anual. Incumbida de concretizar, mediante a realização das despesas fixadas para o exercício, metas e objetivos selecionados pela lei de diretrizes orçamentárias, de acordo com a previsão traçada no plano plurianual e com o ingresso das receitas nos cofres públicos, a lei orçamentária deverá conter os orçamentos fiscal, de investimento das empresas e o da seguridade social, os quais compreendem, nos termos do art. $165, \S 5^{\circ}$, inc. I, da $\mathrm{CF} / 1988$, o seguinte:

\footnotetext{
229 TORRES, Ricardo Lobo. Tratado de direito constitucional financeiro e tributário: o orçamento na Constituição, p. 88-89.

230 "Anões do Orçamento" foi o nome atribuído a um grupo de deputados que não detinham grande notoriedade popular, mas integravam a Comissão Mista do Orçamento no final dos anos 1980 e início dos anos 1990. O grupo ficou famoso após seus integrantes serem descobertos e investigados em uma Comissão Parlamentar de Inquérito (CPI) por estarem envolvidos em fraudes com recursos do orçamento da União em 1993, em que mais R\$ 100 milhões foram desviados. Ao final, o relatório do Deputado Roberto Magalhães (PFL-PE), incluia o pedido de cassação de dezoito dos trinta e sete parlamentares investigados, mas apenas seis foram efetivamente cassados: Carlos Benevides (PMDB-CE), Fábio Raunhetti (PTB-RJ), Feres Nader (PTB-RJ), Ibsen Pinheiro (PMDB-RS), José Geraldo (PMDB-MG) e Raquel Cândido (PTB-RO).

${ }^{231}$ Ibidem, p. 90-92.
} 
I - o orçamento fiscal referente aos Poderes da União, seus fundos, órgãos e entidades da administração direta e indireta, inclusive fundações instituídas e mantidas pelo Poder Público;

II - o orçamento de investimento das empresas em que a União, direta ou indiretamente, detenha a maioria do capital social com direito a voto;

III - o orçamento da seguridade social, abrangendo todas as entidades e órgãos a ela vinculados, da administração direta ou indireta, bem como os fundos e fundações instituídos e mantidos pelo Poder Público.

Como se nota, embora o orçamento seja uno em decorrência do princípio constitucional da unidade, materializa-se em três documentos diferentes, que se harmonizam e se integram finalisticamente ${ }^{232}$, contemplando o último ato do planejamento que tem início com o plano plurianual, onde são estabelecidas as prioridades do Estado.

Além disso, o referido dispositivo consagra o princípio da universalidade, devendo conter expressamente todas as receitas e despesas, e as entidades que detenham ou percebam dinheiro público ${ }^{233}$, o qual difere do princípio da unidade, conforme esclarece Giuliani Fonrouge ${ }^{234}$ :

El principio de universalidad, también conocido como del producto bruto, exige que no haya compensación o confusión entre gastos y recursos; que tanto unos como otros sean consignados en el presupuesto por su importe "bruto" sin extraer saldos "netos". Esta norma es confundida algunas veces con el principio de unidad y no es raro ver atribuido a este último el significado que corresponde a la universalidad [...].

A propósito, Regis Fernandes de Oliveira ${ }^{235}$ ressalta:

[...] nada fica de fora do orçamento anual. As empresas que contem com a participação da União deverão sujeitar-se ao encaminhamento de seu orçamento, na mesma peça. Por aí haverá maior possibilidade do controle sobre elas, inclusive saber de seus planos, para que poderão os recursos ser orientados.

Verifica-se, mais uma vez, que o orçamento influi sobre o destino das empresas públicas e privadas que percebam recursos públicos, ao ponto de a Constituição Federal

\footnotetext{
${ }^{232}$ TORRES, Ricardo Lobo. Curso de direito financeiro e tributário, p. 175.

${ }^{233}$ OLIVEIRA, Regis Fernandes de. Curso de direito financeiro, p. 393.

${ }^{234}$ FONROUGE, Carlos M. Giuliani. Derecho financiero, p. 169.

${ }^{235}$ OLIVEIRA, Regis Fernandes de. Op. cit., p. 393.
} 
brasileira exigir que o projeto de lei orçamentária esteja acompanhado de demonstrativo regionalizado do efeito, sobre as receitas e despesas, decorrente de isenções, anistias, remissões, subsídios e benefícios de natureza financeira, tributária e creditícia (art. $\left.165, \S 6^{0}\right)$.

A LOA contempla, outrossim, o princípio da exclusividade, textualmente previsto no art. $165, \S 8^{\circ}$, da $\mathrm{CF} / 1988$, segundo o qual, "A lei orçamentária anual não conterá dispositivo estranho à previsão da receita e à fixação da despesa, não se incluindo na proibição a autorização para abertura de créditos suplementares e contratação de operações de crédito, ainda que por antecipação de receita".

Nesse aspecto, conforme ensina Regis de Oliveira, "a exclusividade significa que não pode o texto da lei orçamentária instituir tributo, por exemplo, nem qualquer outra determinação que fuja às finalidades específicas de previsão de receita e fixação de despesa" ${ }^{236}$, salvo as exceções expressamente autorizadas no referido dispositivo constitucional.

No que toca ao planejamento, subsistem assim dois pontos, os quais foram destacados com precisão por Estevão Horvath ${ }^{237}$. O primeiro deles, já mencionado, referese ao "demonstrativo", previsto no art. $165, \S 6^{\circ}$, da Lei Maior - e repetido no art. $5^{\circ}$, inc. II, da LRF, mediante o qual se toma conhecimento do que se pretende arrecadar e gastar. Conforme o autor ${ }^{238}$ pondera:

\begin{abstract}
Cuida-se de exigência deveras salutar que funciona como um instrumento para que o Parlamento tome conhecimento - e participe ao depois - da política tributária e financeira do Estado. Conquanto a lei orçamentária não possa criar ou aumentar tributo (princípio da exclusividade), o impacto da "renúncia fiscal" nas contas públicas é absolutamente relevante para a formulação da política tributária e, por ocasião da análise do projeto de lei orçamentária, o Parlamento tem condição de dispor de uma visão geral não somente sobre as despesas a serem efetuadas, mas também a respeito das receitas.
\end{abstract}

O segundo, ainda de acordo com Estevão Horvath, refere-se ao Anexo do projeto de lei orçamentária que, nos termos do art. 5ํㅜㅇ inc. I, da LRF, deve conter o

\footnotetext{
${ }^{236}$ TORRES, Ricardo Lobo. Tratado de direito constitucional financeiro e tributário, p. 384.

${ }^{237}$ HORVATH, Estevão. $O$ orçamento no século XXI: tendências e expectativas, p. 315.

${ }^{238}$ Ibidem, loc. cit..
} 
"demonstrativo da compatibilidade da programação dos orçamentos com os objetivos e metas constantes do documento de que trata o $\S 1^{\underline{0}}$ do art. $4^{\underline{0}}$, e, com isso, crê-se que:

[...] esse é o ponto em que se fecha, ao menos do ponto de vista jurídico, a noção de planejamento plasmada na Constituição e a sua obrigatoriedade; é dizer: não há como sustentar que a Lei Orçamentária Anual não seja obrigada a ser elaborada segundo o plano plurianual e a LDO, cujos detalhes em termos quantitativos e qualitativos estão contidos nesse Anexo, que deve ser seguido para a elaboração da $\mathrm{LOA}^{239}$. (sem grifo no original)

Diante do quanto estabelece a Constituição Federal brasileira e a própria Lei de Responsabilidade Fiscal, torna-se difícil discordar do fato de que as leis orçamentárias instrumentalizam o planejamento modelado e organizado na Constituição do País. Além disso, é por meio delas (PPA, LDO, LOA) que se realizam atos de intervenção no domínio econômico, uma vez que, e conforme será exemplificado adiante, é influenciada - ou ao menos deveria influenciar-se -, a iniciativa privada na condução de suas atividades.

\subsubsection{A periodicidade do orçamento (princípio da anualidade) e sua relevância para o domínio econômico}

Demonstrados o papel e a abrangência das leis orçamentárias para a Administração Pública e para o domínio econômico, torna-se relevante trazer neste momento algumas considerações sobre o princípio da anualidade, a fim de apontar quais as implicações e o quanto se mostra expressiva sua observância para a iniciativa privada.

Instituído no inc. III do art. 165 da CF/1988, o denominado princípio da anualidade deveria, obrigatoriamente, e em conjunto aos demais princípios orçamentários, como o da universalidade, exclusividade e da unidade, ser observado no momento da elaboração e execução da peça orçamentária.

Em razão de os princípios consistirem em regras que defluem do ordenamento jurídico, destinadas a dirigir a sociedade em determinado momento histórico, não há como

\footnotetext{
${ }^{239}$ HORVATH, Estevão. O orçamento no século XXI: tendências e expectativas, p. 315-316.
} 
olvidar, como bem assevere Regis Fernandes de Oliveira, que eles "são mais fortes que meras regras, que podem ser destruídas. Os denominados princípios orçamentários são características específicas que tais leis têm e que as tornam distintas das demais" 240 .

Nesse cenário é que se insere o princípio da anualidade, o qual, somado aos demais princípios que regem a disciplina do orçamento, presta-se não apenas a reforçar a utilização do orçamento como instrumento de controle parlamentar e democrático sobre a atividade financeira do Executivo, mas, também, a orientar sua elaboração, aprovação e execução ${ }^{241}$, cujos impactos podem ser determinantes para a ordem econômica.

Aliomar Baleeiro destaca que "todos eles, em sua essência, visam a resguardar a função política do orçamento como plano de governo que o Legislativo aprova para fiel execução pelo Executivo" ${ }^{242}$.

Além de a Administração Pública estar obrigada a agrupar em uma única peça orçamentária todas as receitas e despesas do Estado (princípio da unidade estabelecido no art. $165, \S 5^{\circ}$, da $\left.\mathrm{CF} / 1988\right)^{243}$, também lhe é imposta a obrigação de atualizar anualmente o orçamento público. Assim, no Brasil, como se observa do art. 165, § 9º̣, I, da CF/1988, cabe à lei complementar dispor sobre o exercício financeiro, que hoje, de acordo com a Lei $\mathrm{n}^{\mathrm{o}} 4.320 / 1964$, vai de $1^{\mathrm{o}}$ de janeiro a 31 de dezembro, ano civil, portanto.

Pode-se afirmar que o referido princípio está ultrapassado, "porque, ao lado do orçamento anual, há o plurianual, denominado 'plano', na Constituição Federal (art. 165, I). Inclusive dentro do orçamento anual há diversos orçamentos (fiscal, de investimento, da seguridade social)"244, no entanto, sua importância é inquestionável, não se limitando, simplesmente, à obrigatoriedade de se renovar a lei orçamentária a cada ano, mas, também, de se observar sua periodicidade.

A propósito, há mesmo um preceito constitucional (art. 167, § 1ํㅡㄹ da CF/1988), segundo o qual "Nenhum investimento cuja execução ultrapasse um exercício financeiro poderá ser iniciado sem prévia inclusão no plano plurianual, ou sem lei que autorize a inclusão, sob pena de crime de responsabilidade.”.

\footnotetext{
${ }^{240}$ OLIVEIRA, Regis Fernandes de. Curso de direito financeiro, p. 382.

${ }^{241}$ SILVA, José Afonso da. Orçamento programa no Brasil, p. 104.

${ }^{242}$ BALEEIRO, Aliomar. Direito tributário brasileiro. 11. ed., rev. e complem. por Misabel Abreu Machado Derzi. Rio de Janeiro: Forense, 2001. p. 411.

${ }^{243}$ TORRES, Ricardo Lobo. Tratado de direito constitucional financeiro e tributário, p. 99.

${ }^{244}$ OLIVEIRA, Regis Fernandes de. Op. cit., p. 385-386.
} 
Como adverte Gilberto Bercovici ${ }^{245}$ :

\begin{abstract}
A garantia mais importante para os contribuintes é a da revisão anual dos orçamentos, que fornece aos seus representantes a oportunidade de reconsiderar o assunto. A periodicidade anual do orçamento é o mais conveniente do ponto político e financeiro, pois permite a aprovação e o controle político em períodos curtos e evita dar ao governo um período longo onde poderia haver discricionariedades na execução orçamentária. Um período menor do que um ano não daria oportunidade para o reconhecimento, contabilização e arrecadação dos tributos e o ordenamento e pagamento das despesas previstas. A anualidade permite ao Congresso intervir periodicamente na atividade financeira do Estado, aprovando a proposta de orçamento e fiscalizando sua aplicação, controlando melhor, dessa maneira, o Poder Executivo.
\end{abstract}

Somam-se a essas particularidades, as mudanças nos desígnios do Estado, de seus objetivos em relação à realização de programas sociais, políticas econômicas e financeiras, que influenciam sobremaneira no domínio econômico. Qualquer mudança intempestiva, imprevista ou autoritária é o bastante para levar todo um sistema à ruína.

Essas também as razões que conduziram o Brasil a adotar o denominado orçamento-programa, o qual constitui uma "técnica orçamentária vinculada ao planejamento econômico e social" ${ }^{246}$. José Afonso da Silva, ao se referir ao plano plurianual, adverte que com ele poderia reconhecer-se um novo princípio, por ele denominado "princípio da plurianualidade das despesas de investimento", o qual, vale ressalvar, "não fura o princípio da anualidade, porque as metas e programas e, portanto, as despesas de capital, constantes do plano plurianual, serão executadas ano a ano pelo orçamento anual" 247 .

Ainda que sujeito a crises e delírios da economia local, do mercado global, dos desejos ou interesses pessoais de governantes brasileiros, o respeito ao princípio da anualidade impediria que, ao menos nesse período de tempo, aqueles que desenvolvem qualquer atividade econômica sejam pegos de surpresa, assegurando-lhes o cumprimento do quanto previsto no orçamento público, ou seja, no planejamento proposto pelo Executivo e aprovado pelo Legislativo.

Ricardo Lobo Torres lembra que, além de permitir o controle do Executivo pelo Legislativo, esse princípio também tem por fundamento evitar a "perpetuidade ou

245 BERCOVICI, Gilberto. Os princípios orçamentários e a primeira Constituição republicana. Revista de Direito Internacional e Econômico, v. 1, n. 1, p. 80-86.

${ }^{246}$ SILVA, José Afonso da. Orçamento programa no Brasil, p. 20.

${ }^{247}$ Idem. Curso de direito constitucional positivo, p. 720. 
permanência da autorização para a gestão financeira", consagrando-se "nas mais importantes Constituições, ainda que, às vezes, combinada com a plurianualidade" ${ }^{248}$.

Nessa mesma linha, João Ricardo Catarino bem sintetiza ao afirmar que o princípio da anualidade "cumpre a finalidade do controle popular, materializado no desejo confesso dos povos de realizar uma discussão sobre os fins da tributação e as prioridades a satisfazer com os recursos coletivos disponíveis" 249 .

Embora as considerações apontadas se mostrem relevantes, não têm sido atribuídos à lei orçamentária a devida importância e respeito, a despeito de, em linhas anteriores, este estudo lembrar os dizeres do ministro Ayres Britto, proferido nos autos da ADI-MC 40481/DF, julgada em 14 de maio de 2008. Nota-se, ultimamente, total descaso e desrespeito à peça orçamentária, bastando, para tanto, recordar os fatos que se sucederam em $1994^{250} \mathrm{e}$ em $2013^{251}$ com a aprovação da lei orçamentária anual. Ambas deveriam ter sido aprovadas, respectivamente, até o final de 1993 e 2012, mas só o foram em novembro de 1994 e abril de 2013, gerando, de acordo com José Maurício Conti, uma "situação de 'anomia orçamentária', iniciando-se o exercício financeiro seguinte sem orçamento, e consequentemente sem autorização para efetuar os gastos públicos, paralisando a administração" 252 .

Infere-se, assim, e ainda que impere no sistema jurídico brasileiro o princípio da transparência, que a peça orçamentária ainda hoje se mostra de difícil compreensão; ininteligível, acaba por contrariar os princípios da certeza e segurança jurídica que, se efetivamente considerados, permitiriam àqueles que desempenham atividades privadas se programarem de forma coordenada e realizarem investimentos de acordo com os desígnios do Estado, bem como iniciar ou desenvolver novas atividades fundados no planejamento materializado por meio do orçamento público.

Afinal, como lembra Alejandro Ramirez Cardona ${ }^{253}$, o orçamento público deve ser elaborado de forma coordenada com o plano econômico nacional, o qual consiste em um

\footnotetext{
${ }^{248}$ TORRES, Ricardo Lobo. Tratado de direito constitucional financeiro e tributário, p. 329/330.

${ }^{249}$ CATARINO, João Ricardo. Finanças públicas e direito financeiro. Coimbra: Almedina, 2012. p. 254.

${ }^{250}$ Lei no 8.933/1994, aprovada em 9 de outubro de 1994.

${ }^{251}$ Lei n ${ }^{-}$12.798/2013, aprovada em 4 de abril de 2013.

${ }^{252}$ CONTI, José Maurício. E o ano começa sem a aprovação do orçamento federal. Consultor Jurídico. Contas à vista. Publicado em 15 jan. 2013. Disponível em: <http://www.conjur.com.br/2013-jan-15/contasvista-ano-comeca-aprovacao-orcamento-federal>. Acesso em: 6 out. 2014.

${ }^{253}$ CARDONA, Alejandro Ramirez. Sistema de hacienda pública. Bogotá: Temis, 1970. p. 484: "Si el plan económico nacional es un proyecto de desarrollo económico y social de toda la economía, de modo que el
} 
projeto de desenvolvimento econômico e social de toda a economia, em que o setor público e o privado aparecem integrados e os orçamentos deverão, necessariamente, a ele se vincular.

Daí a necessidade de se conferir mais respeito e maior obrigatoriedade ao cumprimento da peça orçamentária, em face do que impõem os princípios da anualidade ou plurianualidade, e a crescente interação do orçamento com o sistema econômico, conforme será demonstrado a seguir.

\subsection{O orçamento na Constituição de 1988 e sua interação com o sistema econômico}

Considerados a atual concepção do orçamento e o pensamento de Ricardo Lobo Torres a esse respeito, é a partir dessa ordem de ideias "que se deve apreciar a Constituição Orçamentária de 1988, em parte contraditória e em parte afinada com os problemas e carências atuais do País" ${ }^{\text {254 }}$.

Ricardo Lobo Torres parte de uma Teoria da Constituição Orçamentária em que se analisa o sistema interno ou objetivo, suas normas, a realidade da sociedade brasileira e os conceitos orçamentários $^{255}$, sendo possível notar no texto constitucional efetiva finalidade atribuída ao orçamento público. É o que demonstra o autor ${ }^{256}$, conforme colacionado a seguir:

A Constituição Orçamentária de 1988 é rica em sua expressão principiológica. Se interpretada corretamente, poderá conduzir ao equilíbrio orçamentário, à derrubada generalizada dos incentivos fiscais, à transparência dos gastos e à moralidade no emprego do dinheiro público. Se se abrir à leitura intervencionista e estatizante, conduzirá a uma prática orçamentária cada vez mais afastada das linhas mestras da atividade financeira hodierna.

sector público y el privado aparecen integrados en dicho plan, necesariamente han de vincularse a él los presupuestos financieros públicos y privados".

${ }^{254}$ TORRES, Ricardo Lobo. Tratado de direito constitucional financeiro e tributário, p. 6.

${ }^{255}$ Ibidem, p. 22-23.

${ }^{256}$ Ibidem, p. 6. 
No comentário abalizado de José Afonso da Silva ${ }^{257}$ :

\begin{abstract}
Com a "intervenção estatal na ordem econômica e social, o orçamento passou a ter novas funções, passou a ser um instrumento de programação econômica, de programação da ação governamental, em consonância com a economia global da comunidade a que se refere. Visa a influir na economia global da comunidade a que se refere. É um instrumento de política fiscal, quando procura criar condições para o desenvolvimento nacional, estadual ou municipal, conforme se trate de orçamento federal, estadual ou municipal".
\end{abstract}

Diante do alargamento de suas características e finalidades, verifica-se que a matéria orçamentária, que integra o direito financeiro, comunica-se sobremaneira com outros sistemas jurídicos e, principalmente, com os sistemas econômicos e políticos, dos quais recebe influência direta. Nota-se cada vez mais a presença do Estado no sistema econômico, o qual depende da política para pôr em prática seus projetos e planos governamentais, tanto quanto da economia para financiá-los, eis que aproximadamente $40 \%$ do PIB brasileiro passam pelos orçamentos do Estado.

Receitas e despesas são indissociáveis do conjunto da situação econômica do País. As finanças governamentais mostram-se, a cada dia, dependentes do bom estado dos negócios dos particulares sob pena de restar prejudicado todo o cumprimento do plano de governo ou planejamento instituído pelas leis orçamentárias.

Daí a interligação do orçamento público ao conceito de economia, segundo o qual tem origem na conjugação de dois fatores decorrentes da "vivência quotidiana de cada um: a) as necessidades, além de serem em grande número, expandem-se indefinidamente; b) os recursos para o seu atendimento são, em maior ou menor grau, limitados, finitos, em uma palavra, escassos" ${ }^{258}$, a denotar o que José Afonso da Silva passou a chamar de orçamentoprograma, "de sorte que o orçamento fiscal, os orçamentos de investimento das empresas e o orçamento da seguridade social passam a constituir etapas do planejamento de desenvolvimento econômico e social" ${ }^{259}$.

Somente um orçamento integrado a determinado modelo econômico será capaz de materializar o cumprimento de seus objetivos, compreendido pela forma na qual o Estado organiza suas relações sociais de produção e estrutura sua política de realização dos fatores

\footnotetext{
${ }^{257}$ SILVA, José Afonso da. Orçamento programa no Brasil, p. 41.

${ }^{258}$ NUSDEO, Fábio. Curso de economia: introdução ao direito econômico, p. 28.

${ }^{259}$ SILVA, José Afonso da. Curso de direito constitucional positivo, p. 715
} 
de produção e distribuição do produto do trabalho, classificando-os em dois grandes modelos: o capitalismo e o socialismo ${ }^{260}$.

\subsection{A elaboração da peça orçamentária e os interesses envolvidos: as paixões como fator preponderante}

Já se demonstrou linhas atrás a importância e relevância que o orçamento público assumiu na execução dos desígnios do Estado e perante a sociedade nas últimas décadas, bem como se afirmou que este constitui importante e indispensável instrumento de planejamento, já que às leis orçamentárias é atribuído o papel fundamental de conduzir a política financeira e econômica do País, cujos reflexos e consequências são sentidos e suportados por todos.

Assentou-se, também, que a matéria orçamentária se comunica sobremaneira com outros sistemas jurídicos e, principalmente, com os sistemas econômico e político, dos quais recebe influência direta, tornando o orçamento um poderoso instrumento de intervenção e dominação.

Abordado o caráter instrumental, ideológico e dominador do orçamento público, propõe-se, neste instante, conquanto o assunto já tenha sido tratado com maestria por Regis Fernandes de Oliveira ${ }^{261}$, deve-se, agora, proceder à análise da realidade que envolve as relações humanas na elaboração da peça orçamentária, fugindo um pouco dos aspectos sintático e semântico de que comumente se ocupam os juristas.

Em matéria orçamentária, como já visto, a Constituição Federal atribui ao Poder Executivo a iniciativa na elaboração da lei complementar, que deve dispor "sobre o exercício financeiro, a vigência, os prazos, a elaboração e a organização do plano plurianual, da lei de diretrizes orçamentárias e da lei orçamentária anual” (art. 165, § 9ํㅡ. I).

\footnotetext{
${ }^{260}$ FIGUEIREDO, Leonardo Vizeu. Lições de direito econômico, p. 41.

${ }^{261}$ Veja-se OLIVEIRA, Regis Fernandes de. Gastos públicos, passim.
} 
A plena eficácia dos dispositivos orçamentários, portanto, está adstrita à existência de uma lei complementar que regerá a matéria prevista nos três orçamentos já apresentados neste capítulo.

Em apertada síntese, pode-se dizer que a tramitação legislativa se dá de acordo com as seguintes etapas: (i) o Presidente da República, até 31 de agosto, elabora e envia ao Congresso Nacional o plano plurianual, o projeto de lei de diretrizes orçamentárias e as propostas de orçamento (art. 84, XXIII, da CF/1988); (ii) estes são submetidos à análise e apreciação das duas Casas do Congresso Nacional (art. 166, caput, I e II, da CF/1988), por intermédio de uma Comissão mista permanente, formada por senadores e deputados (art. 166, § 1ํㅗ I, da CF/1988); (iii) apresentadas emendas à Comissão mista, caberá ao Plenário das duas Casas do Congresso Nacional apreciar (art. 166, § 2º , da CF/1988), observadas as exigências constantes do $\S 3^{\circ}$ do referido art. 166; (iv) seguem para promulgação e; por fim, (v) para sanção ou veto presidencial.

Com efeito, ao Poder Executivo cabe escolher o destino dos recursos públicos, por meio da elaboração da proposta de Lei Orçamentária Anual, obedecidos ao Plano Plurianual e ás Leis de Diretrizes Orçamentárias e, como diz Aliomar Baleeiro ${ }^{262}$ :

\footnotetext{
Em todos os tempos e lugares, a escolha do objetivo da despesa envolve um ato político, que também se funda em critérios políticos, isto é, nas idéias, convicções, aspirações e interesses revelados no entrechoque dos grupos detentores de poder. Tanto mais lúcidos, cultos e moralizados sejam os governantes quanto mais probabilidades existem de que se realize aquele cálculo da máxima vantagem social.
}

Afora as despesas obrigatórias, os fundos especiais, as receitas provenientes de contribuições e, principalmente, as receitas vinculadas, que são "utilizadas para individualizar uma fonte e destinação mediante o estabelecimento de um elo jurídico entre receitas e escopos predeterminados" ${ }^{\text {263 }}$, é concedida certa margem de discricionariedade às autoridades do Poder Executivo para decidir sobre como e onde gastar os recursos públicos.

\footnotetext{
${ }^{262}$ BALEEIRO, Aliomar. Uma introdução à ciência das finanças, p. 70.

${ }^{263}$ CARVALHO, André Castro. Vinculação de receitas públicas. São Paulo: Quartier Latin, 2010. p. 37.
} 
Mesmo que a prática brasileira coloque em dúvida essa concepção, o montante disponível à livre alocação no projeto de Lei Orçamentária Anual é significativo ${ }^{264}$ e, diante do engessamento traçado na Constituição Federal de 1988, por meio de sucessivas Emendas Constitucionais, foram criados mecanismos para liberar uma parcela dos recursos orçamentários, dentre os quais a Desvinculação de Receitas da União (DRU).

Embora seja verificada certa predisposição à criação de normas jurídicas que tornem cada vez menor essa discricionariedade, como será observado adiante, nesta dissertação, subsiste a possibilidade de escolhas políticas legadas ao Chefe do Poder Executivo, pois a ele são atribuídas a responsabilidade e a prerrogativa de eleger como as receitas públicas serão gastas, quais investimentos e obras serão realizadas, quais setores da sociedade e da economia serão beneficiados com subsídios, subvenções e emprésti mos etc..

Com isso, novamente vale mencionar as ideias de Thomas Hobbes, segundo o qual, por meio do Chefe do Executivo e do Parlamento, considera-se e se reconhece cada membro da multidão como autor de todos os atos, submetendo-se, assim, "suas vontades à vontade do representante, e seus julgamentos a seu julgamento" ${ }^{265}$.

Adstrito às regras legitimamente instituídas, pode-se dizer que a figura do Estado se confunde com a figura da pessoa eleita, pois a ele é atribuído o direito de representar todos os cidadãos, sem exceção, tanto aqueles que votaram a seu favor como os que votaram contra $^{266}$, pois “O Estado outra coisa não é senão o próprio ser humano com uma instância decisória qualificada. Não se constitui em instância exterior aos indivíduos”267.

Além disso, também não há como afastar o fato de que, diante de sua qualidade humana, "o homem não é só passividade. Ele é um centro de impulso, de sentimentos e de paixões"268 . "Esses homens não fazem outra coisa senão tomar como razão verdadeira as paixões que os dominam,"269.

\footnotetext{
${ }^{264}$ Dados numéricos e estatísticas referentes à vinculação de receitas orçamentárias estão disponíveis em: <http://www.planejamento.gov.br>; e <http://www.orcamentofederal.gov.br/biblioteca/publicacoes_tecnicas/ publicacoes/Vinculacoes_Consolidado.pdf>. Acesso em: 29 nov. 2014.

${ }^{265}$ HOBBES, Thomas. Leviatã ou matéria, forma e poder de um estado eclesiástico e civil, p. 141.

${ }^{266}$ Ibidem, p. 141.

${ }^{267}$ OLIVEIRA, Regis Fernandes de. Gastos públicos, p. 53.

${ }^{268}$ Ibidem, p. 34.

${ }^{269}$ HOBBES, Thomas. Op. cit., p. 42.
} 
O homem age constantemente em busca do prazer, seja influenciado por suas paixões ou por seus desejos, como assim dizem Nicolau Maquiavel e David Hume; pela vontade de viver, de acordo com Arthur Schopenhauer; ou pela libido, como denomina Sigmund Freud; seja aspirando à felicidade que, segundo o próprio Freud, possui dois lados - "por um lado, a ausência de dor e desprazer, por outro a vivência de sensações intensas de prazer" 270 .

De acordo com Baruch de Espinosa, "É opinião geral dos filósofos que as paixões atormentadoras da vida humana são como vícios, em que incidimos, por culpa nossa." ${ }^{, 271}$.

Diz-se, assim, que as decisões envolvendo o orçamento público, além de se sujeitarem às influências sociais, psicológicas, religiosas, políticas e econômicas, também se sujeitam às paixões que atormentam, seja para o bem, seja para o mal, aquele que detém a prerrogativa de eleger os gastos públicos.

Por mais que se criem regras, mecanismos de fiscalização e responsabilização, o que a história demonstra é “o predomínio constante das vontades particulares que encontram seu ambiente próprio em círculos fechados e pouco acessíveis a uma ordenação impessoal" $" 272$.

Como Arthur Schopenhauer adverte, os atos de vontade "têm sempre um fundamento, fora deles mesmos, nos seus motivos" ${ }^{273}$, sendo impossível extrair uma explicação do "querer" em sua essência, levando, consequentemente, à certeza de que todo ato tem como fenômeno um ato de vontade, o qual se dá por uma série de motivos que formam o caráter do indivíduo e que consiste na sua vontade, o objeto mais imediato da sua consciência, a essência íntima do seu próprio fenômeno, e que está fora do domínio do princípio da razão ${ }^{274}$.

Em suma, e de acordo com esse filósofo, a vontade "age cegamente e segundo causas que, sob este ponto de vista, denominamos excitações" ${ }^{275}$. A individualidade, no

\footnotetext{
${ }^{270}$ FREUD, Sigmund. $O$ mal-estar na cultura. Tradução de Renato Zwick; revisão técnica e prefácio de Márcio Seligmann-Silva; ensaio bibliográfico de Paulo Endo e Edson Souza. Porto Alegre: L\&PM, 2011. p. 62.

${ }^{271}$ SPINOZA, Baruch de. Tratado político, p. 34.

${ }^{272}$ HOLANDA, Sérgio Buarque de. Raízes do Brasil. 26. ed. São Paulo: Companhia das Letras, 2012. p. 106.

${ }^{273}$ SCHOPENHAUER, Arthur. O mundo como vontade e representação. Tradução de M. F. Sá Correia. 4. reimpressão. Rio de Janeiro: Contraponto, 2001. p. 116.

${ }^{274}$ Ibidem, p. 119-122.

${ }^{275}$ Ibidem, p. 124.
} 
homem, se sobressai, detendo cada um seu caráter próprio e, por isso, o mesmo motivo não tem o mesmo poder sobre todos ${ }^{276}$.

Além disso, como forma de maquiar ou manipular interesses, o homem pode, com o auxílio da razão, fingir um caráter que não tem e, influenciado pelas circunstâncias externas que favorecem os motivos, esse caráter reagirá de acordo com a natureza de cada indivíduo ${ }^{277}$, impondo a necessidade de "sondá-lo e arrancar-lhe o seu segredo, visto que a razão o torna altamente capaz de dissimulação" 278 .

A propósito, são esclarecedoras as distinções traçadas por Arthur Schopenhauer, ao advertir que:

No animal, vemos, de certo modo, a vontade de viver mais a descoberto do que no homem; no homem, com efeito, o conhecimento que a disfarça está tão desenvolvido, a faculdade de fingir a dissimula tão bem, que a sua verdadeira essência só se pode mostrar às claras por acaso e por momentos. ${ }^{279}$

Ao tratar do assunto, Thomas Hobbes ${ }^{280}$ também faz referência aos animais, esclarecendo que:

[...] embora essas criaturas possam usar de certa forma e voz para dar a conhecer umas às outras seus desejos e sentimentos, elas carecem da arte das palavras, por meio da qual alguns homens são capazes de apresentar aos outros o que é bem sob a aparência do mal, e o que é mal sob a aparência do bem, ou de aumentar ou diminuir a importância visível do bem ou do mal, semeando o descontentamento entre os homens e perturbando sua paz por simples capricho.

Afetado pelo mundo a todo instante, qualquer ser humano que ocupe uma posição na esfera do Estado está sujeito aos seus sentimentos, não tendo como abandoná-los ${ }^{281}$. Em outras palavras, "assim funcionam os sentimentos, e estes são levados para o interior do Estado, através de seus agentes"282.

\footnotetext{
${ }^{276}$ SCHOPENHAUER, Arthur. O mundo como vontade e representação, p. 127.

${ }^{277}$ Ibidem, p. 164.

${ }^{278}$ Ibidem, loc. cit..

${ }^{279}$ Ibidem, p. 165.

${ }^{280}$ Ibidem, p. 165.

${ }^{281}$ OLIVEIRA, Regis Fernandes de. Gastos públicos, p. 49.

${ }^{282}$ Ibidem, p. 50.
} 
Em sendo a decisão de gastar fundamentalmente política ${ }^{283}$, está sujeita à vontade, aos desejos, à libido, enfim, às paixões daqueles que governam o país, consistindo esta:

[...] a substância íntima, o núcleo tanto de toda coisa particular, como do conjunto; é ela que se manifesta na força natural cega; ela encontra-se na conduta racional do homem; se as duas diferem tão profundamente, é em grau e não em essência $^{284}$.

Impregnado de vários atributos, bons ou ruins, não restam dúvidas de que as decisões tomadas em relação à peça orçamentária também são motivadas por interesses particulares, por crueldade ou por justiça, por sabedoria ou temor; afinal:

Os seres humanos desejam aquilo que amam, e odeiam coisas pelas quais têm aversão. Assim, desejo e amor são as mesmas coisas, só que, com desejo significamos sempre a ausência do objeto e, com amor, sua presença. Assim também, com a aversão significamos a ausência e, com o ódio, a presença do objeto $^{285}$.

Motivada pelo desejo ou pelo ódio, pelo ímpeto de justiça ou injustiça, a decisão acerca da realização do gasto público certamente poderá beneficiar alguns em detrimento de outros, como exemplifica Regis Fernandes de Oliveira ${ }^{286}$ :

Fácil perceber que os afetos humanos estão em efervescência durante todo o tempo. Imaginemos que, na composição do orçamento, se discuta sobre a desapropriação de uma determinada área urbana que envolverá a derrubada da casa de um desafeto político. A deliberação envolve o sentimento de ódio do governante, que busca destruir o bem de seu inimigo. Alegrar-se-á com a despesa que envolve a desapropriação do imóvel do outro. De seu lado, se puder intervir para manter o imóvel em pé, se o imóvel é de seu amigo e compadre político, isso significará alegria, por outra forma.

Não há, assim, como afastar o fato de que os representantes políticos do povo sofram influências das paixões no momento de elaborarem as leis orçamentárias, os programas governamentais e ao colocarem em prática as políticas públicas. Os recursos

\footnotetext{
${ }^{283}$ OLIVEIRA, Regis Fernandes de. Gastos públicos, p. 292.

${ }^{284}$ SCHOPENHAUER, Arthur. O mundo como vontade e representação, p. 119.

${ }^{285}$ HOBBES, Thomas. Leviatã, ou matéria, forma e poder de um estado eclesiástico e civil, p. 49.

${ }^{286}$ OLIVEIRA, Regis Fernandes de. Gastos públicos, p. 49.
} 
públicos são destinados de acordo com as paixões, desejos, libido e afetos que atingem os governantes e, por isso, o conteúdo orçamentário deixa, muitas vezes, de guardar compatibilidade com os valores a que, racionalmente, deveria atender. 


\section{RECEITA TRIBUTÁRIA, EXTRAFISCALIDADE E INTERVENÇÃO NO DOMÍNIO ECONÔMICO}

\subsection{Entradas e receitas - conceito, distinção e classificação}

Conforme sublinhado, o Estado, para cumprir suas finalidades e com isso atender às necessidades estabelecidas na Constituição Federal, tem de auferir recursos, os quais, de acordo com Geraldo Ataliba, podem ser obtidos de duas maneiras: "auferindo lucros, na venda de bens e serviços, ou usando de seu poder para exigir o concurso compulsório das pessoas sujeitas a seu poder, para as necessidades públicas" ${ }^{287}$.

A propósito, Aliomar Baleeiro ${ }^{288}$ salienta que todos os processos de financiamento do Estado se enquadram, ou já se enquadraram historicamente, em um dos seguintes meios de obtenção de receita: (i) extorsão; (ii) recolhimento de rendas, produzidos pelos bens e empresas do Estado; (iii) exigência coativa de tributos e penalidades; (iv) tomada de empréstimos; e (v) fabricação de dinheiro metálico ou papel moeda.

Atualmente, o Estado brasileiro, para obter recursos necessários à satisfação de suas despesas, vale-se principalmente: (i) da cobrança de tributos; (ii) da exploração de seu patrimônio, a qual pode dar-se em decorrência do percebimento de valores provenientes de empresas estatais, com a comercialização de recursos minerais, petrolíferos e energéticos, e em decorrência da concessão de bens públicos; e, ainda, (iii) da contração de empréstimos.

Daí, portanto, é que se diz genericamente que "receita é a soma de dinheiro percebida pelo Estado para fazer face à realização dos gastos públicos" ${ }^{289}$, ainda que nem toda receita possa assim ser considerada, pois esse conceito, como adverte Ricardo Lobo

\footnotetext{
${ }^{287}$ ATALIBA, Geraldo. Apontamentos das ciências das finanças, direito financeiro e tributário. São Paulo: Revista dos Tribunais, 1969. p. 25.

${ }^{288}$ BALEEIRO, Aliomar. Uma introdução à ciência das finanças, p. 115.

${ }^{289}$ TORRES, Ricardo Lobo. Curso de direito financeiro e tributário, p. 185.
} 
Torres, é "fundamentalmente baseado no de ingresso" e "dele se estrema, pois o ingresso corresponde também à entrada de dinheiro que ulteriormente será restituído" 290 .

Nessa linha também se manifestou Regis Fernandes de Oliveira ${ }^{291}$, ao afirmar que "nem todo ingresso, todavia, constitui receita. Há entradas que ingressam provisoriamente nos cofres públicos, podendo neles permanecer ou não. Destinam-se a ser devolvidas" ${ }^{292}$ e, portanto, são denominadas entradas provisórias, como por exemplo, os empréstimos compulsórios.

A contrapor-se às entradas provisórias, há aquelas denominadas entradas definitivas, ou seja, "as que advêm do poder constritivo do Estado sobre o particular, sejam independentes de qualquer atuação (imposto), sejam dela dependentes (taxa) ou em decorrência da realização de obras públicas (contribuição de melhoria)" 293 .

Aliomar Baleeiro, levando em consideração os aspectos apontados, conceitua receita pública como “[...] a entrada que, integrando-se no patrimônio público sem que quaisquer reservas, condições ou correspondência no passivo, vem acrescer o seu vulto, como elemento novo e positivo" 294 .

Pode-se assim dizer que receita pública é aquela que se destina a permanecer em definitivo nos cofres públicos, ou, como sublinha Regis Fernandes de Oliveira, "é a entrada definitiva de dinheiro e bens nos cofres públicos"295.

Como a entrada consiste em definitivo de dinheiro e bens nos cofres públicos, verifica-se que ela pode provir de diversas fontes ou formas de receita. E, com o propósito de empregar maior controle e transparência ao orçamento público, passou-se a proceder ao seu agrupamento por categorias e a estabelecer determinados modos de classificação que variam de acordo com a necessidade e o interesse de quem os estabelece.

Para que se tenha uma ideia de sua amplitude, no âmbito Federal, o detalhamento da classificação da receita cabe à Secretaria de Orçamento Federal (SOF) e é feito por

\footnotetext{
${ }^{290}$ TORRES, Ricardo Lobo. Curso de direito financeiro e tributário, p. 185.

${ }^{291}$ OLIVEIRA, Regis Fernandes de. Curso de direito financeiro, p. 126-127.

${ }^{292}$ Ibidem, p. 126.

${ }^{293}$ Ibidem, p. 127.

${ }^{294}$ BALEEIRO, Aliomar. Uma introdução à ciência das finanças, p. 116.

${ }^{295}$ OLIVEIRA, Regis Fernandes de. Op. cit., p. 128.
} 
meio de portaria, na qual são estabelecidas as classificações orçamentárias de acordo com sua natureza e fonte de recursos ${ }^{296}$.

Em face da grande diversidade de classificações, as quais, novamente, cumpre frisar, não são verdadeiras nem falsas, mas úteis ou inúteis, como ensina Genaro Carrió ${ }^{297}$, será adotado um critério que se aproxime do objeto de estudo da presente dissertação e que se mostre útil, a fim de evitar classificações puramente abstratas e sem critério algum.

A classificação jurídica, nesse sentido, mostra-se a mais pertinente, por ser proveniente da análise do ordenamento normativo e, ao mesmo tempo, econômica, pois leva em conta a pessoa que desenvolve a atividade econômica que propicia a geração de riqueza convertida em receita.

Além do mais, essa classificação mostra-se relevante para o presente estudo na medida em que, e por meio dela, será possível identificar quais e onde se encontram alocadas as principais fontes de receita do Estado, bem como demonstrar dentre elas sua relevância para o domínio econômico, uma vez que é por meio delas que são desenvolvidas todas as atividades do Estado e praticados os atos de intervenção.

\subsubsection{Receitas ordinárias e extraordinárias}

De acordo com o critério da regularidade ou relativa periodicidade, as receitas públicas também se classificam em ordinárias e extraordinárias.

Em suma, as receitas ordinárias caracterizam-se por serem periódicas e por comporem permanentemente o orçamento do Estado, enquanto as receitas extraordinárias são as que se produzem excepcionalmente, como as doações e os impostos extraordinários $^{298}$, ou seja, "receitas que, pelo seu caráter temporário, irregular e

\footnotetext{
${ }^{296}$ Veja-se BRASIL. Ministério do Planejamento, Orçamento e Gestão; Secretaria de Orçamento Federal. Ementário de receitas da União. Disponível em: <http://www.orcamentofederal.gov.br/informacoesorcamentarias/arquivos-receitas-publicas/receitas-publicas>. Acesso em: 12 nov. 2014.

${ }^{297}$ CARRIÓ, Genaro. Notas sobre derecho y lenguaje, p. 99.

298 TORRES, Ricardo Lobo. Curso de direito financeiro e tributário, p. 186.
} 
contingente, ou pelas circunstâncias eventuais e excepcionais de que se revestem, não se enquadram no rol dos ingressos permanentes e ordinários do Tesouro" 299.

A relevância do presente critério será abordada no Capítulo 5, oportunidade em que tratar-se-á da dívida e do crédito público, sua natureza jurídica, mudanças de paradigmas que a conduziram à qualidade de receita ordinária e, ao final, sua relevância e influência sobre o domínio econômico. Nesse aspecto, notar-se-á, que a periodicidade com que os Estados passaram a contrair dívidas como forma de obtenção de recursos e o destino empregado foram determinantes para a mudança de paradigmas e conceitos.

\subsubsection{Receita originária e derivada}

A classificação da receita pública em originária e derivada é a mais aceita e difundida pela doutrina especializada, pois se mostra consonante com o Direito pátrio vigente.

A assertiva do parágrafo anterior é corroborada pelo fato de a Lei $\mathrm{n}^{\mathrm{o}} 4.320 / 1964$, no art. $9^{\circ}$, caracterizar as receitas tributárias como derivadas e, com isso, além do econômico, adotar o critério da origem para distinguir as receitas entre aquelas provenientes do próprio setor público (originárias), e as advindas do setor privado (derivadas). É o que será abordado a seguir.

\subsubsection{Receitas originárias}

Provenientes do próprio setor público, as receitas originárias são aquelas “decorre[ntes] da exploração, pelo Estado, de seus próprios bens ou quando pode exercer

${ }^{299}$ BALEEIRO, Aliomar. Uma introdução à ciência das finanças, p. 116-117. 
sob o que se denomina de direito público disponível” ${ }^{300}$. Em suma, são geradas com a exploração do patrimônio do Estado e compreendem:

[...] as rendas provenientes dos bens e empresas comerciais ou industriais do Estado, que os explora à semelhança de particulares, sem exercer os seus poderes de autoridade, nem imprimir coercitivamente à exigência de pagamentos ou à utilização dos serviços que os justificam, embora, não raro, os institua em monopólios. A essas receitas originárias corresponderia a noção de "preços" [...]. Nelas poderiam ser incluídas as receitas decorrentes da prescrição em favor do Estado, bens vacantes, heranças jacentes etc. ${ }^{301}$.

Ricardo Lobo Torres ${ }^{302}$ observa que as receitas originárias agrupam duas espécies de receitas públicas: (i) os ingressos patrimoniais e (ii) os ingressos comerciais.

Os ingressos patrimoniais correspondem às rendas provenientes da exploração direta do patrimônio público e são obtidos com a exploração dos bens dominiais do Estado, como florestas, ilhas, estradas, imóveis etc..

Revestidas de variadas naturezas jurídicas - foros, laudêmios, aluguéis etc. -, suas principais formas são o preço público, as compensações financeiras e as participações especiais, bem como as partilhas ${ }^{303}$.

O preço público, cujo termo é empregado como sinônimo de "tarifa" pela doutrina e pela jurisprudência, consiste na prestação pecuniária devida ao Estado a título de contraprestação pelos serviços públicos não essenciais prestados ao indivíduo ou à empresa. Detém como princípio fundamental o da proporcionalidade ou do benefício e impõe, ao cidadão que recebe o benefício do Estado, a obrigação de despender recursos idênticos ao benefício total recebido pela entrega dos serviços públicos.

Nota-se, assim, que o preço público detém caráter vinculado ou contraprestacional, pois visa remunerar o Estado pela prestação de serviços públicos não essenciais, diferenciando-se das taxas, que são receitas tributárias e, com isso, derivadas.

As compensações financeiras, por sua vez, têm fundamento jurídico constitucional no $\S 1^{\circ}$ do art. 20, o qual assegura aos Estados, Distrito Federal, Municípios e aos órgãos

\footnotetext{
${ }^{300}$ OLIVEIRA, Regis Fernandes de. Curso de direito financeiro, p. 130.

${ }^{301}$ BALEEIRO, Aliomar. Uma introdução à ciência das finanças, p. 117.

${ }^{302}$ TORRES, Ricardo Lobo. Curso de direito financeiro e tributário, p. 188-194.

${ }^{303}$ Ibidem, p. 188.
} 
da administração direta da União, participação no resultado da exploração de petróleo ou gás natural, de recursos hídricos para fins de geração de energia elétrica e de outros recursos minerais no respectivo território, plataforma continental, mar territorial ou zona econômica exclusiva, ou compensação financeira por essa exploração.

Diante disso, as compensações financeiras podem assumir (i) caráter indenizatório, o qual decorre da utilização dos recursos naturais situados no território do ente federativo e que se justifica, por conta das despesas geradas pelas empresas exploradoras desses recursos aos poderes públicos; ou (ii) caráter participativo, em que o ente público passa a perceber uma participação calculada sobre o resultado da exploração do petróleo ou gás natural ou outros bens públicos.

Quanto aos ingressos comerciais, estes têm origem na prática de formas intervencionistas do Estado na economia, mediante a instituição de monopólios (correios), criação de empresas estatais e através das loterias (concurso de prognósticos), cujas receitas são auferidas com fundamento na distribuição de dividendos ${ }^{304}$.

Assim, as receitas originárias provêm da exploração, pelo Estado, de seu próprio patrimônio, não compreendendo dentre elas as receitas resultantes da arrecadação tributária, conforme será observado a seguir.

\subsubsection{Receitas derivadas}

As receitas derivadas, por sua vez, "provêm do constrangimento sobre o patrimônio do particular" ${ }^{305}$ ou, como elucida Aliomar Baleeiro ${ }^{306}$, caracterizam-se pelo constrangimento legal para sua arrecadação, figurando dentre elas os tributos e as penas pecuniárias como as multas, por exemplo ${ }^{307}$.

\footnotetext{
${ }^{304}$ RUBINSTEIN, Flávio. Orçamentos públicos: a lei 4.320/1964 comentada. 2. ed. São Paulo: RT, 2010. p. 53-54.

${ }^{305}$ OLIVEIRA, Regis Fernandes de. Curso de direito financeiro, p. 130.

${ }^{306}$ Ibidem, p. 117.

${ }^{307}$ De acordo com Regis Fernandes de Oliveira, a multa “é sanção de tipo pecuniário que atinge o patrimônio do transgressor de uma norma administrativa, a título de dano presumido da infração, ou de cunho
} 
Trata-se de rendas que o Estado colhe no setor privado, por ato de autoridade, e que se subdividem em: (i) impostos; (ii) taxas; (iii) contribuições de melhoria; e (iv) contribuições parafiscais, as quais, atualmente, se denominam contribuições sociais ou de intervenção no domínio econômico e de interesse das categorias profissionais ou econômicas (art. 149 da CF/1988) e que, portanto, assumiram natureza jurídica tributária.

Somam-se a elas, a cobrança das sanções e o perdimento decorrente de contrabando, apreensão de armas, bens e pertences provenientes do crime etc..

A propósito, Flávio Rubinstein ${ }^{308}$ bem sintetiza ao esclarecer que:

\begin{abstract}
Essas receitas configuram, portanto, meio de financiamento do Estado que não representa riqueza nova, mas mera transferência daquela que foi gerada por terceiros. Para a geração desta riqueza, não se emprega o patrimônio público, tampouco se desenvolvem atividades econômicas por parte dos entes públicos.
\end{abstract}

Além das receitas mencionadas, Regis Fernandes de Oliveira ${ }^{309}$ acrescenta uma terceira espécie ou categoria de receita derivada, a qual denomina receitas transferidas. Embora também provenham do patrimônio do particular - a título de tributo -, o que a aparta das demais é o fato de não ser arrecadada pela entidade política que vai utilizá-las (cf. arts. 157 a 162 da CF/1988).

Com isso, pode-se dizer, em síntese, que as receitas públicas são ordinárias ou extraordinárias de acordo com a regularidade com que são obtidas e que, quanto a sua origem, distinguem-se em receitas originárias, derivadas e transferidas, levando-se em conta o fato de provirem, respectivamente, do patrimônio do próprio Estado ou do patrimônio do particular.

meramente punitivo" (OLIVEIRA, Regis Fernandes de. Infrações e sanções administrativas. 3. ed. rev., atual. e ampl. São Paulo: Revista dos Tribunais, 2012b. p. 143).

${ }^{308}$ RUBINSTEIN, Flávio. Orçamentos públicos: a lei 4.320/1964 comentada, p. 54.

${ }^{309}$ Ibidem, p. 130. 


\subsection{Extrafiscalidade e intervenção no domínio econômico: oneração e desoneração}

Apresentadas as principais distinções e características das entradas e receitas percebidas pelo Estado, verifica-se, neste momento, que as receitas derivadas tomam salutar relevância para o objeto do presente estudo, destacando-se dentre elas o imposto como um dos principais instrumentos de intervenção no domínio econômico, ao lado do gasto público ${ }^{310}$.

Essa assertiva é corroborada por Luís S. Cabral de Moncada, quando, ao tratar do intervencionismo, bem assinala que, "No quadro das finanças contemporâneas do dirigismo o Estado pretende obter da sua actividade financeira fins de ordem socioeconómica e não apenas arrecadar receitas." 311.

Além disso, em um Estado autodenominado "Estado do Imposto", cuja principal fonte de financiamento é predominantemente tributária ${ }^{312} \mathrm{e}$, portanto, proveniente de receitas derivadas, oriundas do constrangimento exercido sobre o patrimônio privado para a arrecadação de tributos ${ }^{313}$ ou, como prefere Regis Fernandes de Oliveira, de "receitas que ingressam por força da ação constritiva do Estado" 314 , tornar-se-ia impossível deixar de assim proceder. Afinal, como lembra o autor ${ }^{315}$,

[...] desde tempos imemoriais, os povos sempre cobraram por suas guerras de conquista. Na Roma Antiga, as colônias dominadas eram obrigadas a pagar tributos, ou seja, uma quantia calculada em pecúnia ou em bens (produtos agrícolas, gado etc.) ou em serviços (escravos que prestavam serviços abrindo estradas, limpando as propriedades etc.). Tais prestações irradiaram-se através da Idade Média, apenas adquirindo contornos jurídicos e restrições através dos pactos de conquistas dos direitos humanos, tais como a Carta Magna, a "Petition of Rights", a Revolução Francesa, a Independência Americana e as Constituições que se seguiram (francesa, norte-americana, mexicana, Weimar), bem as das modernas democracias ocidentais.

\footnotetext{
${ }^{310}$ DEODATO, Alberto. As funções extra-fiscais do imposto. 1949. Tese (Concurso de Professor Catedrático de Ciência das Finanças) - Faculdade de Direito da Universidade de Minas Gerais, Belo Horizonte, 1949. p. 64-65.

${ }_{311}^{31}$ MONCADA, Luís S. Cabral de. Direito económico, p. 41.

312 SCHOUERI, Luís Eduardo. Normas tributárias indutoras e intervenção econômica. Rio de Janeiro: Forense, 2005. p. 1.

${ }^{313}$ Dados disponíveis em: <http://www.camara.gov.br>. Acesso em: 14 nov. 2014

${ }^{314}$ OLIVEIRA, Regis Fernandes de. Curso de direito financeiro, p. 148.

${ }^{315}$ Ibidem, p. 150.
} 
A propósito, Alberto Deodato esclarece que "só quando o grupo privado passou das necessidades gerais às coletivas, foi que os homens, associados politicamente, sentiram a carência do tributo" ${ }^{316}$. Com isso, "Já não eram mais a água, o alimento, a diversão, a literatura, mas a ordem e a defesa do grupo"317 que tornavam necessário e imprescindível impor o constrangimento sobre o patrimônio privado.

Para que se tenha uma ideia do montante envolvido, em 2013, a estimativa da receita total da União, de acordo com a Lei $\mathrm{n}^{\mathrm{o}} 12.798 / 2013$, era de $\mathrm{R} \$$ 2.165.910.805.669,00, dos quais $\mathrm{R} \$ 956.551 .800 .557,00$ seriam provenientes do orçamento fiscal; $\mathrm{R} \$ 599.293 .304 .522,00$, do orçamento da seguridade social; e $\mathrm{R} \$$ 610.065.700.590,00, do refinanciamento da dívida fiscal.

Ao final do exercício de 2013, e de acordo com as informações disponibilizadas pela Secretaria do Tesouro Nacional, do total estimado foram arrecadados $\mathrm{R} \$$ 1.018.730.970,00, conforme se extrai do quadro a seguir (Quadro 3.1).

Quadro 3.1 - Estimativa da receita total da União e receita realizada em 2013

$\mathrm{R} \$$ milhares

\begin{tabular}{|c|c|c|}
\hline ESPECIFICAÇÃO & $\begin{array}{c}\text { PREVISÃO DE } \\
\text { ARRECADAÇÃO }\end{array}$ & $\begin{array}{l}\text { RECEITA REALIZADA EM } \\
2013 \\
\end{array}$ \\
\hline Receita Tributária & 418.840 .125 & 376.042 .389 \\
\hline Receita de Contribuições & 658.606 .237 & 642.688 .581 \\
\hline Receita Patrimonial & 109.786 .992 & 85.183 .285 \\
\hline Receita Agropecuária & 23.831 & 26.494 \\
\hline Receita Industrial & 1.054 .374 & 925.163 \\
\hline Receita de Serviços & 49.105 .442 & 49.545 .002 \\
\hline Transferências Correntes & 995.931 & 732.973 \\
\hline $\begin{array}{l}\text { Receitas Correntes a } \\
\text { Classificar }\end{array}$ & 0 & 100 \\
\hline Outras Receitas Correntes & 58.055 .551 & 64.501 .823 \\
\hline TOTAL & 1.219.645.809 & 1.296.468.483 \\
\hline
\end{tabular}

Fonte: Secretaria do Tesouro Nacional. Disponível em: <http://www.tesouro.fazenda.gov.br>. Acesso em: 24 nov. 2014.

\footnotetext{
${ }^{316}$ DEODATO, Alberto. As funções extra-fiscais do imposto, p. 62.

${ }^{317}$ Ibidem, loc. cit..
} 
Além disso, conforme já sublinhado, o Estado, desde sua instituição, sempre interveio no domínio econômico, havendo, no entanto, momentos ou períodos históricos em que essa intervenção se operava de forma ora mais branda, ora mais híspida, não se tratando, assim, e como pontua Luís S. Cabral de Moncada ${ }^{318}$, de um fenômeno historicamente permanente e idêntico em termos qualitativos e quantitativos.

A presença de regras sobre as liberdades econômicas ou a regulação da própria ordem econômica há tempos integram os ordenamentos jurídicos e as próprias Constituições de vários países, manifestando-se "em todas elas a função extrafiscal do Direito Financeiro como pressuposto para efetividade das instrumentalidades da Constituição Econômica"319.

Daí, portanto, é que se pode dizer que o orçamento público assume uma função extrafiscal, em que os tributos e, mais especificamente, os impostos, são empregados como um dos principais instrumentos de que o Estado lança mão para intervir na economia e no domínio econômico, pois são comumente utilizados para "fomentar ou mesmo corrigir, controlar e conformar o funcionamento espontâneo da decisão económica privada" ${ }^{320}$.

Com efeito, não se está aqui descobrindo nada de novo, apenas sublinhando o valor essencial do elemento teleológico na compreensão adequada do fenômeno financeiro, no que se refere à redistribuição de riquezas e a qual pode dar-se tanto com a realização de gastos quanto mediante os ingressos públicos, influenciando as condutas privadas ${ }^{321}$.

Logo, e com o propósito de demonstrar o quanto se tem afirmado neste trabalho que o orçamento é um importante instrumento de intervenção no domínio econômico -, torna-se indispensável tratar especificamente dos tributos como fonte de receita, da fiscalidade e extrafiscalidade, para, em seguida, demonstrar sua utilização como instrumento de intervenção sobre o domínio econômico.

\footnotetext{
${ }^{318}$ MONCADA, Luís S. Cabral de. Direito económico, p. 41.

${ }^{319}$ TORRES, Heleno Taveira. Teoria da constituição financeira, p. 199-200.

${ }^{320}$ MONCADA, Luís S. Cabral de. Op. cit., p. 36.

${ }^{321}$ GONZÁLEZ, Luis Manuel Alonso. Los impuestos autonómicos de caracter extrafiscal. Madrid: Marcial Pons, 1995. p. 15.
} 


\subsubsection{Tributos: fiscalidade e extrafiscalidade}

Tributo, dentre suas várias acepções ${ }^{322}$, é definido no art. $3^{\circ}$ do Código Tributário Nacional (CTN) como toda prestação pecuniária compulsória, em moeda ou cujo valor nela se possa exprimir, que não constitua sanção de ato ilícito, instituída em lei e cobrada mediante atividade administrativa plenamente vinculada.

Rubens Gomes de Souza define tributo como sendo a

[...] receita derivada que o Estado arrecada mediante o emprego da sua soberania, nos termos fixados em lei, sem contraprestação diretamente equivalente, e cujo produto se destina ao custeio das finalidades que lhe são próprias $^{323}$.

O conceito proposto por Geraldo Ataliba ${ }^{324}$, compartilhado também por esta dissertação, acrescenta que

tributo é a obrigação jurídica pecuniária, ex lege, que se não constitui em sanção de ato ilícito, cujo sujeito ativo é uma pessoa pública (ou delegado por lei desta), e cujo sujeito passivo é alguém nessa situação posto pela vontade da lei, obedecidos os desígnios constitucionais (explícitos ou implícitos).

Como salienta Regis Fernandes de Oliveira ${ }^{325}$ ao decompor a definição proposta por Geraldo Ataliba, "o tributo não é o pagamento, mas a obrigação de entregar dinheiro (pecuniária) aos cofres públicos”.

$\mathrm{Na}$ contramão do pensamento de boa parte da doutrina ${ }^{326} \mathrm{e}$, portanto, do entendimento de que a obrigação tributária detém caráter pecuniário, ou seja, deve ser satisfeita em dinheiro, Alfredo Augusto Becker defende posição segundo a qual "o tributo,

${ }^{322}$ CARVALHO, Paulo de Barros. Curso de direito tributário. 13. ed. São Paulo: Saraiva, 2000. p. 19-24.

${ }^{323}$ SOUZA, Rubens Gomes de. Compêndio de legislação tributária. Coord. IBET - Instituto Brasileiro de Estudos Tributários; obra póstuma. São Paulo: Resenha Tributária, 1975. p. 39.

${ }^{324}$ ATALIB A, Geraldo. Hipótese de incidência tributária. 6. ed. São Paulo: Malheiros, 2000. p. 34.

${ }^{325}$ OLIVEIRA, Regis Fernandes de. Curso de direito financeiro, p. 150.

${ }^{326}$ Dentre os que não são adeptos à teoria defendida por Alfredo Augusto Becker, figuram: JÈZE, Gaston. Principios generales del derecho administrativo, v. II, t. I, p. 252; INGROSSO, Giovanni. Diritto finanziario, p. 98; FALCÃO, Amílcar de Araújo. Introdução ao direito tributário. Rio de Janeiro: Ed. Financeiras, 1955. p. 34-36. 
no plano material, não precisa ser dinheiro, pode perfeitamente consistir numa coisa (prestação in natura) ou num serviço (prestação in labore) ${ }^{\text {,327. }}$.

A fim de justificar seu posicionamento, Alfredo Augusto Becker ${ }^{328} \operatorname{argumenta:~}^{2}$

\begin{abstract}
O dever jurídico de prestação em dinheiro é dever de dar determinada quantidade de unidade ideal de valor conduzida (ou incorporada) pelo dinheiro. Por sua vez, este dever jurídico de prestação em dinheiro pode não ser originário, mas derivado da transformação de um dever, originariamente, in natura ou in labore; transformação sugerida pela função econômica do dinheiro que pode servir de substitutivo de toda e qualquer prestação de outra natureza.

Portanto, a fim de que a relação jurídica tenha natureza jurídica tributária, pouco importa que a obrigação, por ela gerada, seja satisfeita por uma prestação em dinheiro ou in natura ou in labore, pois, nas três hipóteses, o conteúdo jurídico da prestação será sempre o mesmo: um prestar, isto é, um ato positivo (facere) ou um ato negativo (non facere) do sujeito passivo na relação jurídica. Por sua vez, o sujeito ativo, no outro pólo da relação jurídica, terá, nas três hipóteses, sempre o mesmo direito de natureza pessoal.
\end{abstract}

Embora se mostre adequada a posição externada por Alfredo Augusto Becker, a ideia de que a obrigação jurídica tributária, consistente em pagar tributo, deve se realizar mediante a entrega de dinheiro aos cofres públicos se coaduna com o pensamento defendido nesta dissertação, valendo assinalar que as obrigações jurídicas aludidas "independem da vontade do sujeito passivo, que deve efetivá-la, ainda que contra seu interesse" 329 .

É daí, consequentemente, que advém a denominação das receitas derivadas, ou seja, como são identificados os valores que integram o caixa da entidade pública que provêm do constrangimento sobre o patrimônio do particular ${ }^{330}$ e cuja "finalidade última almejada pela lei, no caso, é a transferência de dinheiro das pessoas privadas, submetidas ao poder do Estado, para os cofres públicos" 331 .

Em suma, o tributo constitui uma espécie de receita e um instituto próprio do direito financeiro, cuja definição e instituição, sob o ponto de vista jurídico, a ele está atrelado e não ao direito tributário ${ }^{332}$ como se

\footnotetext{
${ }^{327}$ BECKER, Alfredo Augusto. Teoria geral do direito tributário. 3. ed. São Paulo: Lejus, 2002. p. 286.

${ }^{328}$ Ibidem, p. 633.

${ }^{329}$ CARVALHO, Paulo de Barros. Curso de direito tributário, p. 25.

${ }^{330}$ OLIVEIRA, Regis Fernandes de. Curso de direito financeiro, p. 130.

${ }^{331}$ ATALIBA, Geraldo. Hipótese de incidência tributária, p. 29.

${ }^{332}$ SOUZA, Rubens Gomes de. Compêndio de legislação tributária, p. 39.
} 
presumiria $^{333}$. Não por menos, Fernando Pérez Royo ${ }^{334}$ assinala, ao conceituar tributo, o fato de a lei vincular o dever de contribuir, com o propósito de obter recursos necessários para sustentar os gastos públicos.

Daí a exigência e nascimento dos tributos, os quais devem ser instituídos por lei e de acordo com o texto constitucional, conforme reza o inc. II do art. $5^{\circ}$, da Constituição Federal, ao estabelecer que "ninguém será obrigado a fazer ou deixar de fazer algu ma coisa senão em virtude de lei”, e o inc. I do art. 150, quando veda aos entes tributantes, detentores da prerrogativa de instituir e arrecadar tributos, que exijam ou aumentem tributo sem lei que o estabeleça.

A história tem mostrado a necessidade de se impor limites à liberdade de tributar conferida ao Estado, pois, como afirmou John Marshall, Chief of Justice da Corte dos Estados Unidos da América, no caso McCulloch v. Maryland, de 1819, quando o Estado de Maryland insistia em cobrar impostos do Second Bank of the United States, "o poder de tributar envolve o poder de destruir".

Embora o contribuinte, devedor de qualquer espécie de tributo, não possa questionar sua aplicação - se o gasto está sendo ou não realizado em seu proveito -, pode exigir que sua imposição se dê em consonância com as regras jurídicas de competência, de acordo com o princípio da isonomia, e que sua inserção seja devidamente lançada na peça orçamentária $^{335}$.

Ademais, como Regis Fernandes de Oliveira ${ }^{336}$ assevera:

\begin{abstract}
$\mathrm{O}$ tributo não pode constituir-se em sanção de ato ilícito. Para este existe a multa, ou seja, a prática de ato ilícito pressupõe o descumprimento de uma norma jurídica, isto é, ter um comportamento contrário ao previsto na lei. Nesta hipótese, a reação do ordenamento jurídico ocorre através de uma sanção. Se a repulsa ao comportamento antijurídico é a sanção, não há possibilidade de, em razão dele, exigir-se um tributo.
\end{abstract}

\footnotetext{
${ }^{333}$ Conforme Geraldo Ataliba assinala, "o conceito de tributo para o direito é um conceito jurídico privativo, que se não pode confundir com o conceito financeiro, ou econômico de outro objeto, de outros setores científicos, como é o tributo ontologicamente considerado. Tributo, para o direito, é coisa diversa de tributo como conceito de outras ciências" (ATALIBA, Geraldo. Hipótese de incidência tributária, p. 23).

${ }^{334}$ ROYO, Fernando Pérez. Derecho financiero y tributario: parte general. 20. ed. Sevilla: Thomson Reuters, 2010. p. 38

${ }^{335}$ BECKER, Alfredo Augusto. Teoria geral do direito tributário, p. 289.

${ }^{336}$ Ibidem, p. 150.
} 
Desponta, com isso, uma das principais atribuições ou finalidades do tributo: a fiscalidade, ou seja, "o comportamento do Poder Público com o único intuito de abastecimento dos cofres públicos. É o poder de instituição de tributos, desprovido de qualquer finalidade que não a arrecadatória" 337 .

O termo fiscalidade, como assinala Paulo de Barros Carvalho ${ }^{338}$, é empregado "para representar valores finalísticos que o legislador imprime na lei tributária", verificado

[...] sempre que a organização jurídica do tributo denuncie que os objetivos que presidiram sua instituição, ou que governam certos aspectos da sua estrutura, estejam voltados ao fim exclusivo de abastecer os cofres públicos, sem que outros interesses - sociais, políticos ou econômicos - interfiram no direcionamento da atividade impositiva ${ }^{339}$.

Todavia, na hipótese de se agregar ao propósito meramente arrecadatório da fiscalidade a intenção de conformar comportamentos, ter-se-á o que se denomina por extrafiscalidade, a qual, também de acordo com Paulo de Barros Carvalho, consiste na "forma de manejar elementos jurídicos usados na configuração dos tributos, perseguindo objetivos alheios aos meramente arrecadatórios" ${ }^{340}$.

Os objetivos citados, como diz o autor, podem ser traduzidos em providências tendentes a prestigiar certas situações sociais, políticas ou econômicas, às quais o legislador dispensa tratamento mais confortável ou menos gravoso ${ }^{341}$, bem como se prestam a desestimular comportamentos contrários a situações socialmente indesejáveis ${ }^{342}$, podendo-se, com isso, afirmar:

La pura fiscalidad no existe, así como tampoco la extrafiscalidad pura. Los efectos de los tributos no son identificables por separado y, en alguna medida, coexisten funciones recaudatorias y reguladoras con distinta intensidad conforme a la naturaleza propia de cada tributo ${ }^{343}$.

\footnotetext{
${ }^{337}$ OLIVEIRA, Regis Fernandes de. Curso de direito financeiro, p. 162.

${ }^{338}$ Ibidem, p. 228.

${ }^{339}$ Ibidem, loc. cit..

${ }^{340}$ Ibidem, p. 229.

${ }^{341}$ Ibidem, p. 228-229.

${ }^{342}$ Ibidem, p. 162.

${ }^{343}$ ROSEMBUJ, Tulio. Elementos de derecho tributario. In: GONZÁLEZ, Luis Manuel Alonso. Los impuestos autonómicos de caracter extrafiscal, p. 21.
} 
Em alguns tributos, especialmente nos chamados impostos indiretos ${ }^{344}$, os quais incidem sobre situação instantânea e são suportados por terceiros ${ }^{345}-$ v.g., Imposto sobre Operações Relativas à Circulação de Mercadorias e sobre Prestação de Serviços de Transporte Interestadual e Intermunicipal e de Comunicação (ICMS), Imposto sobre Produtos Industrializados (IPI) e Contribuição para o Financiamento da Seguridade Social (Cofins) - essas características se afloram e, não obstante a evidente função fiscal, é possível afirmar que são utilizados como instrumentos intervencionistas, ainda que mediatamente não se possa excluir o princípio da capacidade contributiva ${ }^{346}$.

Mostra-se importante, neste momento, tratar dos objetivos da extrafiscalidade, os quais foram sintetizados com precisão por Aliomar Baleeiro ${ }^{347}$, nos seguintes termos:

Quando os impostos são empregados como instrumento de intervenção ou regulação pública, a função fiscal propriamente dita, ou "puramente fiscal", é sobrepujada pelas funções "extrafiscais". A sua técnica é, então, adaptada ao desenvolvimento de determinada política, ou diretriz.

Com efeito, os tributos não se prestam apenas a abastecer os cofres do Estado para que este possa atender às necessidades pactuadas solenemente. Além dessa função, e de modo geral, também servem à promoção e desenvolvimento do domínio econômico, à regularização e fiscalização da economia e, com isso, assumem verdadeiro caráter interventivo, seja para restringir a prática de determinados atos ou comportamentos, seja para fomentar e até mesmo induzir a iniciativa privada a fazer ou deixar de fazer algo.

\subsubsection{A extrafiscalidade como instrumento de intervenção}

Diante do proposto inicialmente, faz-se pertinente, mais uma vez, esclarecer que não se tem como propósito abordar as espécies de tributo e sua classificação, tampouco os

\footnotetext{
${ }^{344}$ De acordo com Geraldo Ataliba, "É classificação que nada tem de jurídica; seu critério é puramente econômico. Foi elaborada pela ciência das finanças, a partir da observação do fenômeno econômico da translação ou repercussão dos tributos" (ATALIBA, Geraldo. Hipótese de incidência, p. 143).

${ }^{345}$ OLIVEIRA, Regis Fernandes de. Curso de direito financeiro, p. 165.

${ }^{346}$ TORRES, Heleno Taveira. Teoria da constituição financeira, p. 227.

${ }^{347}$ BALEEIRO, Aliomar. Uma introdução à ciência das finanças, p. 176.
} 
aspectos da hipótese de incidência tributária ${ }^{348}$. O objeto de análise limitar-se-á, neste tópico, a demonstrar de que forma os tributos são utilizados como instrumento de intervenção sobre o domínio econômico, bem como sua relevância e eventuais reflexos.

Daí por diante, e partindo do pressuposto que todos os tributos de uma forma ou de outra exercem certa função extrafiscal ${ }^{349}$, pois há séculos são percebidos os efeitos da tributação sobre redistribuição do capital e da renda entre os indivíduos e sobre a formação das classes sociais ${ }^{350}$, pode-se dizer que a extrafiscalidade

[...] é sempre uma tributação com fim "físcal" (competência tributária) à qual são atrelados "motivos constitucionais" materiais de outras competências (da Constituição Econômica ou da Constituição Social, por exemplo), como concretização dos fins constitucionais do Estado, na forma e condições autorizadas pela própria Constituição ${ }^{351}$.

A propósito, Alfredo Augusto Becker ${ }^{352}$ já assinalava que a extrafiscalidade assumiria a posição de principal finalidade de muitos tributos, sobrepondo-se, com isso, a arrecadação de recursos para o custeio das despesas públicas e, consequentemente, consistiria em importante instrumento de intervenção estatal no meio social e na economia privada.

Com o intuito de demonstrar o quanto afirmam os autores em comento, mostra-se pertinente citar alguns dos exemplos propostos por Aliomar Baleeiro ${ }^{353}$, os quais demonstrarão que a extrafiscalidade atua sobre o domínio econômico com a finalidade de prestigiar certas situações sociais, políticas ou econômicas. Vejam-se:

(i) majoração dos impostos sobre importação (II), circulação de bens e mercadorias (ICMS) e sobre produtos industrializados (IPI), como instrumento de proteção à produção nacional, agrícola ou fabril ou de combate ao luxo;

(ii) redução ou desoneração de impostos com o propósito de promover o amparo à saúde pública e à higiene alimentar;

\footnotetext{
${ }^{348}$ Para aprofundamento sobre o tema, remete-se às lições de OLIVEIRA, Regis Fernandes de. Curso de direito financeiro, p. 164-179.

${ }^{349}$ TORRES, Heleno Taveira. Teoria da constituição financeira, p. 229.

${ }^{350}$ BALEEIRO, Aliomar. Uma introdução à ciência das finanças, p. 179.

${ }^{351}$ TORRES, Heleno Taveira. Op. cit., p. 229.

${ }^{352}$ BECKER, Alfredo Augusto. Teoria geral do direito tributário, p. 269.

${ }^{353}$ BALEEIRO, Aliomar. Op. cit. p. 178-179.
} 
(iii) “fragmentação dos latifúndios ou remembramento de minifúndios e punição do ausentismo por impostos progressivos sobre a área desocupada ou sobre heranças recebidas por pessoas residentes fora da jurisdição do governo, que exerce o poder de tributar";

(iv) incentivos por isenções à instalação de indústrias novas;

(v) estímulos à construção e ao aproveitamento de áreas urbanas desocupadas, degradadas etc.;

(vi) restabelecimento da propensão ao consumo, como política fiscal em que se institua mais impostos progressivos sobre a herança e a renda; etc..

Além desses, merece destaque a citada utilização da extrafiscalidade como "política fiscal para manutenção do equilíbrio econômico pelo controle das tendências à flutuação

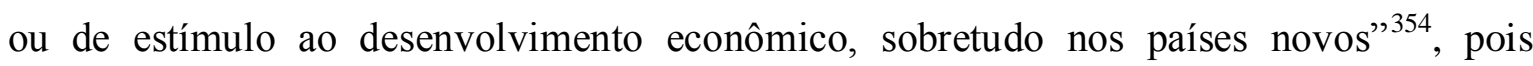
intimamente atrelado aos objetivos propostos inicialmente neste estudo, em que se busca demonstrar que o orçamento constitui importante instrumento de intervenção no domínio econômico, sendo merecedor de maior atenção e responsabilidade daqueles que o elaboram e executam.

Como Aliomar Baleeiro adverte, "para obtenção de qualquer dos fins acima expostos, existe problema de prognósticos de efeitos econômicos e de escolha de técnica adequada"355, cabendo, assim, ao legislador e ao Poder Executivo, ponderar os efeitos econômicos das medidas que adotam desde a elaboração da peça orçamentária.

Por constituir o orçamento "a lei periódica que contém previsão de receitas e fixação de despesas, programando a vida econômica e financeira do Estado, de cumprimento obrigatório, vinculativa do comportamento do agente público" ${ }^{356}$, sua elaboração, conforme se observou, não deveria jamais dar-se sem qualquer planejamento, o qual, como também já salientado, consiste em uma "forma de ação racional caracterizada pela previsão de comportamentos econômicos e sociais futuros, pela formulação explícita de objetivos e pela definição de meios de ação coordenadamente dispostos" 357 .

\footnotetext{
${ }^{354}$ BALEEIRO, Aliomar. Uma introdução à ciência das finanças, p. 179.

${ }^{355}$ Ibidem, loc. cit.

${ }^{356}$ OLIVEIRA, Regis Fernandes de. Curso de direito financeiro, p. 366.

${ }^{357}$ GRAU, Eros Roberto. A ordem econômica na Constituição de 1988, p. 150.
} 
Por isso caracteriza-se a extrafiscalidade pelo "emprego deliberado do instrumento tributário para finalidades [...] regulatórias de comportamentos sociais, em matéria econômica, social e política" ${ }^{358}$, e, como propõe Luís Eduardo Schoueri ${ }^{359}$, tratar-se-ia de "normas tributárias indutoras como espécie do gênero extrafiscalidade".

Tanto é assim que essas questões foram objeto de preocupação do constituinte originário nos arts. $150, \S 6^{\circ}, 155, \S 2^{\circ}$, inc. XII, alínea $g$, e $165, \S 6^{\circ}$, e do constituinte derivado, por ocasião da edição da Emenda Constitucional no 42/2003, a qual acrescentou ao texto constitucional o art. 146-A, ao dispor que cabe à lei complementar "estabelecer critérios especiais de tributação, com o objetivo de prevenir desequilíbrios da concorrência".

A despeito das diversas modalidades de intervenção já abordadas, a extrafiscalidade, a qual detém dentre uma de suas espécies as normas tributárias indutoras, de acordo com Luís Eduardo Schoueri, constitui um modo de intervenção por indução no domínio econômico, o qual se dá por meio da criação e instituição de estímulos ou desincentivos do Estado. Nas palavras do referido autor ${ }^{360}$, a

[...] indução por estímulos, proporciona o Estado, vantagens adicionais àqueles que incorrem nos atos contemplados pela norma, que não seriam obtidas no livre funcionamento do mercado; no caso de desincentivos, recai o destinatário da norma em custos que não lhe seriam imputados, em caso de livre curso do mercado.

Luís Eduardo Schoueri salienta ainda que, longe de constituir uma exceção, as normas tributárias indutoras surgem em obediência ao preceito constitucional da atuação positiva do Estado, tornando-se um potente instrumento para atuação em determinado sentido político, seja na escolha dos sujeitos que devem suportar os ônus devidos por dado programa de despesas, seja na escolha dos fatos cuja concretização faz nascer a obrigação tributária $^{361}$.

\footnotetext{
${ }^{358}$ ATALIB A, Geraldo. Sistema constitucional tributário brasileiro. São Paulo: Revista dos Tribunais, 1968. p. $150-151$.

${ }^{359}$ SCHOUERI, Luís Eduardo. Normas tributárias indutoras e intervenção econômica, p. 32-34.

${ }^{360}$ Ibidem, p. 54.

${ }^{361}$ Ibidem, p. 87.
} 
Justificada está, em razão disso, a adoção de determinadas medidas indutoras ou de incentivo, como a isenção, a subvenção e até mesmo a renúncia de receita, que tem como um de seus principais objetivos beneficiar a sociedade e, por consequência, o domínio econômico e que, de acordo com Ricardo Lobo Torres ${ }^{362}$, tratar-se-ia de privilégios, ou seja, uma

[...] permissão para fazer ou deixar de fazer alguma coisa contrária ao direito comum. Pode ser negativo, como o privilégio fiscal consistente nas isenções e reduções de tributos, que implicam sempre uma concessão contrária à lei. Pode ser positivo, como o privilégio financeiro representado pelos incentivos, subvenções, subsídios e restituições de tributo, que consubstanciam a concessão de tratamento preferencial.

Neste aspecto, é válido lembrar que o art. 14 da LRF $^{363}$ impõe à concessão ou ampliação de incentivos ou benefícios de natureza tributária decorrente de renúncia de receita a adoção "de certas medidas de cautela fiscal para que seja considerada legal”364.

A propósito, Eros Roberto Grau ${ }^{365}$, com supedâneo em escritos de outros doutrinadores, sintetiza e esclarece que:

362 TORRES, Ricardo Lobo. Tratado de direito constitucional, financeiro e tributário: o orçamento na Constituição, p. 261.

${ }^{363}$ Veja-se: "Art. 14. A concessão ou ampliação de incentivo ou benefício de natureza tributária da qual decorra renúncia de receita deverá estar acompanhada de estimativa do impacto orçamentário-financeiro no exercício em que deva iniciar sua vigência e nos dois seguintes, atender ao disposto na lei de diretrizes orçamentárias e a pelo menos uma das seguintes condições:

I - demonstração pelo proponente de que a renúncia foi considerada na estimativa de receita da lei orçamentária, na forma do art. 12, e de que não afetará as metas de resultados fiscais previstas no anexo próprio da lei de diretrizes orçamentárias;

II - estar acompanhada de medidas de compensação, no período mencionado no caput, por meio do aumento de receita, proveniente da elevação de alíquotas, ampliação da base de cálculo, majoração ou criação de tributo ou contribuição.

$\S 1^{\circ}$ A renúncia compreende anistia, remissão, subsídio, crédito presumido, concessão de isenção em caráter não geral, alteração de alíquota ou modificação de base de cálculo que implique redução discriminada de tributos ou contribuições, e outros benefícios que correspondam a tratamento diferenciado.

$\S 2^{\underline{o}}$ Se o ato de concessão ou ampliação do incentivo ou benefício de que trata o caput deste artigo decorrer da condição contida no inciso II, o benefício só entrará em vigor quando implementadas as medidas referidas no mencionado inciso.

$\S 3^{\circ} \mathrm{O}$ disposto neste artigo não se aplica:

I - às alterações das alíquotas dos impostos previstos nos incisos I, II, IV e V do art. 153 da Constituição, na forma do seu $\S 1^{\circ}$;

II - ao cancelamento de débito cujo montante seja inferior ao dos respectivos custos de cobrança.".

${ }^{364}$ RUBINSTEIN, Flávio. Boa-fé objetiva no direito financeiro e no direito tributário brasileiros. 2008.213

f. Dissertação (Mestrado) - Universidade de São Paulo, São Paulo, 2008, p. 139.

${ }^{365}$ GRAU, Eros Roberto. A ordem econômica na constituição de 1988, p. 191-192. 
A ordem econômica na Constituição de 1988 contempla a economia de mercado, distanciada porém do modelo liberal puro e ajustada à ideologia neoliberal (Washington Peluso Albino de Souza); a Constituição repudia o dirigismo, porém acolhe o intervencionismo econômico, que não se faz contra o mercado, mas a seu favor (Tércio Sampaio Ferraz Júnior); a Constituição é capitalista, mas a liberdade apenas é admitida enquanto exercida no interesse da justiça social e confere prioridade aos valores do trabalho humano sobre todos os demais valores da economia e mercado (José Afonso da Silva).

É o que também se extrai do já citado art. 174 da Constituição Federal, o qual atribui ao Estado, dentre outras, a função de incentivar o setor privado, facilmente percebido quando este se vale da extrafiscalidade para intervir sobre o domínio econômico.

Para tanto, basta verificar que os Estados comumente recorrem aos tributos para: (i) simplificar ou diminuir os custos da administração; (ii) promover a equidade; (iii) corrigir desvios do mercado econômico; (iv) promover a equalização de rendas entre regiões; (v) promover ou incentivar determinados setores da economia com a concessão de subvenções, como adiante demonstrado etc.

Alberto Deodato bem pontua que "o imposto não é somente um meio de cobrir as necessidades financeiras, mas um meio de cobertura que intervém, também, para corrigir a repartição das rendas e da fortuna que se opera sob o império da livre concorrência" ${ }^{366}$.

O patrimônio dos particulares que pretendem usufruir desses benefícios condicionados é diretamente afetado, uma vez que, diante da promessa de serem beneficiados, também podem ser induzidos a realizar investimentos e, com isso, despender recursos a fim de atender às respectivas condições de concessão desses benefícios ${ }^{367}$.

Benvenuto Griziotti ${ }^{368}$ segue esse raciocínio ao afirmar que:

El impuesto puede inducir a los contribuyentes a aumentar la producción o perfeccionar sus métodos (por ejemplo: con reducción de derroches de mano de obra o de subproductos o con el empleo de máquinas modernas) para alejar o remover (de ahí el término de remoción del impuesto) la carga tributaria. Con la mayor producción aumenta la oferta y disminuyen los precios, con sucesivas influencias sobre la economía de los empresarios y de los consumidores.

\footnotetext{
${ }^{366}$ DEODATO, Alberto. As funções extra-fiscais do imposto, p. 27.

${ }^{367}$ RUBINSTEIN, Flávio. Boa-fé objetiva no direito financeiro e no direito tributário brasileiros, p. 139.

${ }^{368}$ GRIZIOTTI, Benvenuto. Principios de ciencia de las finanzas. 6. ed. Buenos Aires: Depalma. 1959. p. 97.
} 
Em razão disso, não há como afastar o fato de que os tributos, como receitas orçamentárias que são, exercem fundamental papel de intervenção sobre o domínio econômico, conformando e orientando-o.

Acabam por impor ou, no mínimo, induzir a iniciativa privada - o contribuinte - a adotar determinada conduta ou medida que pode redundar em significativo efeito para o Estado e para a sociedade como um todo.

Como assinala Armando Giorgetti ${ }^{369}$, o sujeito passivo da obrigação tributária, diante do dever de pagar determinado imposto, reagirá de forma diversa de outros e de acordo com seus impulsos e das circunstâncias de tempo e lugar.

Além disso, e de acordo com as razões individuais de cada contribuinte, as quais podem ser "legítimas" ou "ilegítimas", diferentes efeitos de ordem econômica poderão ser sentidos ${ }^{370}$. Os impactos negativos ou positivos poderão refletir na distribuição de lucros, nos níveis de investimentos e até mesmo nos salários, influindo, consequentemente, no aumento ou diminuição da economia.

Nessa linha de pensamento é a lição de Aliomar Baleeiro ${ }^{371}$, para quem

\begin{abstract}
Os tributos provocam diferentes reações econômicas e psicológicas dos contribuintes. Poderão estimular o pleno emprego e até o inconveniente hiperemprego. Poderão também ativar a preferência pela liquidez, através da oferta maciça de mercadorias para realizar disponibilidades de dinheiro em caixa, suscitando baixa de preços e até a depressão.
\end{abstract}

Por fim, e levando em conta que o propósito perseguido pelo Estado é a promoção da justiça social e não intervir no domínio econômico, mas fiscalizando e incentivando a atividade privada, a extrafiscalidade assume o papel de importante instrumento de promoção da justiça social.

\footnotetext{
${ }^{369}$ GIORGETTI, Armando. Lezioni di scienza delle finanze e di diritto finanziario. Padova: Dott. Antonio Milani, 1972. p. 50-51.

${ }^{370}$ Ibidem, p. 51.

${ }^{371}$ BALEEIRO, Aliomar. Uma introdução à ciência das finanças, p. 152.
} 
Mostra-se oportuno, assim, citar as três medidas exemplificativas enumeradas por Héctor Belisario Villegas ${ }^{372}$, segundo o qual:

1) Pueden producirse medidas disuasivas con respecto a actividades que no se consideran convenientes, por lo cual se procede a desalentarlas mediante medios financieros, como es el incremento de alícuotas en los tributos, la creación de sobretasas, adicionales o recargos.

2) Per el contrario, el Estado puede decidir realizar acciones alentadoras para atraer ciertas actividades económicas, científicas, culturales o de otro tipo, que estime necesarias y útiles para el país. En tal caso, despliega una serie de medidas que pueden consistir en exenciones de tributos, diferimientos, deducciones, reintegros, etcétera.

3) También se desarrolla finalidad extrafiscal por medios financieros cuando se resuelve percibir tributos de alto monto para debilitar ciertas posiciones patrimoniales y redituarias de los sujetos que se desea alcanzar, como manera de modificar la estructura en la distribución de los patrimonios y las rentas.

De outra sorte, nem sempre a indução manifesta-se em termos positivos. O Estado, quando onera o contribuinte criando ou elevando determinado imposto, tal como no caso de importação de determinados bens, busca restringir ou evitar esse comportamento, podendo-se dizer que a indução é negativa ${ }^{373}$.

A norma, ainda que não proíba a importação desses bens, onera-a de tal modo que a torna economicamente proibitiva.

De fato, há impostos cuja finalidade não é render, como se verifica "quando se estabelece um imposto contra o luxo ou contra o álcool; quando se cria uma tarifa alta para certas mercadorias importadas; quando se diminui o imposto sobre as novas construções" ${ }^{374}$. O Estado opta por afastar os efeitos do não rendimento, anulando a ostentação do luxo inútil, eliminando ou aliviando a chaga social do alcoolismo e, "sendo nula a importação de certas mercadorias estrangeiras, florescem as indústrias nacionais similares, enriquecendo a economia",375.

O Estado se apropria da extrafiscalidade como instrumento versátil e intercambiário para esquematizar e simplificar sua utilização como mecanismo de promoção, incentivo e

\footnotetext{
${ }^{372}$ VILLEGAS, Héctor Belisario. Curso de finanzas, derecho financiero y tributario. 9. ed. Buenos Aires: Depalma, 2007. p. 15.

${ }^{373}$ GRAU, Eros Roberto. A ordem econômica na Constituição de 1988, p. 149.

${ }^{374}$ DEODATO, Alberto. As funções extra-fiscais do imposto, p. 64-65.

${ }^{375}$ Ibidem, p. 65.
} 
estímulo ao setor privado, ou, em sentido contrário, como instrumento de limitação, freio, desincentivo e até mesmo sanção ${ }^{376}$.

Esses mecanismos, além de terem de ser utilizados de acordo com os limites e ditames legais, são facilmente identificados no sistema jurídico brasileiro por meio da isenção, remissão, alteração da base de cálculo ou alíquota de determinado tributo, do diferimento e, até mesmo, da renúncia de receita, para provocar os efeitos desejados na economia e na sociedade.

Pari passu, as previsões orçamentárias apontadas geram expectativas naqueles que delas poderão se valer direta e indiretamente e, "quando frustradas, poderão levar à violação do princípio da boa-fé objetiva" ${ }^{377}$.

Não apenas os tributos, mas as finanças como um todo, e cada vez mais, têm se revelado poderoso instrumento nas mãos dos governos para a consecução de fins de caráter econômico, político e social, sendo difícil fixar limites que sejam capazes de apontar onde acaba a finalidade fiscal e onde começam os fins político-econômicos.

É o que se notará, também, ao tratar do gasto público e da dívida pública, pois, na hipótese de se levar em conta que todo o orçamento é um ato político, também será preciso considerar o fato de que todos os atos praticados pelos governantes são motivados por razões ideológicas, por dominação e movidos por interesses pessoais, os quais, evidentemente, não se reduzem a atos de maldade ou vingança.

\footnotetext{
${ }^{376}$ GONZÁLEZ, Luis Manuel Alonso. Los impuestos autonómicos de caracter extrafiscal, p. 47.

${ }^{377}$ RUBINSTEIN, Flávio. Boa-fé objetiva no direito financeiro e no direito tributário brasileiros, p. 137.
} 


\section{O GASTO PÚBLICO E O DOMÍNIO ECONÔMICO}

\subsection{O gasto público como mecanismo de intervenção no domínio econômico}

Nos subitens a seguir, assim como fora feito ao estudar a receita tributária, tratarse-á especificamente do gasto público e de sua utilização como instrumento de intervenção no domínio econômico.

Para tanto, serão apresentados os principais conceitos e a classificação das despesas públicas e, após breve análise acerca de seu caráter vinculativo, buscar-se-á demonstrar de que forma a previsibilidade do gasto público interfere na atividade desempenhada pela iniciativa privada e como esta reage, ou ao menos poderia reagir, diante das estimativas apresentadas pelo Estado.

Percorrido esse caminho, proceder-se-á ao estudo das subvenções econômicas e sua atual relevância para o domínio econômico; ao final, serão apresentados os principais problemas que podem surgir diante de uma política subvencionista.

\subsubsection{Conceito e classificação das despesas públicas}

Aliomar Baleeiro ${ }^{378}$ propõe dois conceitos de despesa pública: o primeiro "designa o conjunto de dispêndios do Estado, ou de outra pessoa de direito público, para o financiamento dos serviços públicos" e, o segundo, consiste na "aplicação de certa quantia, em dinheiro, por parte da autoridade ou agente público competente, dentro duma autorização legislativa, para execução de fim a cargo do governo".

${ }^{378}$ BALEEIRO, Aliomar. Uma introdução à ciência das finanças, p. 65. 
Em outras palavras, e como sintetiza Ricardo Lobo Torres, pode-se dizer que "a despesa pública é a soma dos gastos realizados pelo Estado para a realização de obras e para a prestação de serviços públicos" ${ }^{379}$.

Após a entrada dos recursos, os quais provêm da arrecadação de tributos, do próprio patrimônio do Estado - exploração, arrendamento e venda de propriedades - e até mesmo da contratação de empréstimos públicos, como será observado adiante, neste trabalho, o Estado toma a decisão de aplicá-los com o propósito de atender a determinadas finalidades, que, como visto, são previamente traçadas nas leis orçamentárias.

É por meio dessa decisão política, materializada no planejamento orçamentário, que o Estado obedece - ou ao menos deveria obedecer -, a determinados critérios para satisfazer as necessidades públicas e realizar investimentos.

Estabelecidas as prioridades, mediante prévia autorização legislativa (arts. 165, §§ 5ํㅜ 6ํㅜ e 9ํㅜ 167 e 169 da CF/1988), o Estado estará autorizado a realizar a despesa, ou seja, a promover a saída do dinheiro dos cofres públicos, o que também deve dar-se de acordo com as formas estabelecidas em lei ${ }^{380}$. Afinal, o Estado, por meio do gasto público, tem de adquirir material bélico; arcar com as despesas dos edifícios da Administração Pública em que funcionam os tribunais de justiça, as embaixadas etc.; pagar os salários de funcionários, dentre eles, policiais, juízes, diplomatas e empregados públicos; construir ou pagar a construção de pontes, estradas, ferrovias, hidrelétricas, hospitais, escolas; outorgar subsídios; conceder subvenções econômicas; realizar investimentos etc..

Para tanto, faz-se necessário distinguir as despesas públicas a fim de diferenciar devidamente as obrigações assumidas pelo Estado, as quais, de certa maneira, cada vez mais têm se mostrado heterogêneas entre si.

Embora vários critérios sejam satisfatórios, tomar-se-á como ponto de partida, neste trabalho, o critério estabelecido na Lei $\mathrm{n}^{\mathrm{o}}$ 4.320/1964, que é preponderantemente econômico. Previsto no art. 12, o critério de que se vale a lei distingue as despesas públicas em: (i) despesas correntes, as quais estão fundamentalmente atreladas à realização de serviços e, que, por seu turno, dividem-se em (i.a) despesas de custeio e (i.b) transferências correntes; e em (ii) despesas de capital, as quais se vinculam à aquisição ou

\footnotetext{
${ }^{379}$ TORRES, Ricardo Lobo. Curso de direito financeiro e tributário, p. 194.

${ }^{380}$ OLIVEIRA, Regis Fernandes de. Curso de direito financeiro, p. 292.
} 
produção de bens e se classificam em: (ii.a) investimentos, (ii.b) inversões financeiras e (ii.c) transferências de capital.

O referido critério, como adverte Kleber Luiz Zanchim ${ }^{381}$, não é aleatório e, como visto, leva em consideração as consequências produzidas pelas despesas públicas, individualmente. As primeiras, ditas correntes, não agregam ativos para o ente que as realiza, enquanto as últimas possuem exatamente essa finalidade, contribuindo para a introdução de um ativo no patrimônio do ente público.

Assim, classificam-se como despesas de custeio as dotações para manutenção de serviços anteriormente criados, inclusive as destinadas a atender a obras de conservação e adaptação de bens imóveis (art. $12, \S 1^{\mathrm{o}}$ ), e dentre as quais se incluem as despesas com pessoal, material de consumo, serviço de terceiros etc. Já as transferências correntes compõem as dotações para despesas, às quais não corresponda contraprestação direta em bens ou serviços, inclusive para contribuições e subvenções destinadas a atender à manifestação de outras entidades de direito público ou privado (art. $12, \S 2^{\circ}$ ), incluindo as subvenções econômicas e sociais, as despesas com inativos, as pensões, as transferências intergovernamentais e os juros da dívida contratada ${ }^{382}$.

Dentre as despesas de capital, a qual está vinculada à aquisição ou produção de bens, encontram-se as despesas de investimentos, nelas compreendidas as dotações para o planejamento e a execução de obras, inclusive as destinadas à aquisição de imóveis considerados necessários à realização destas últimas (art. 12, § $4^{\mathrm{o}}$ ); as inversões financeiras, compostas pelas dotações destinadas à aquisição de imóveis ou bens de capital já em utilização ou à aquisição de títulos representativos do capital de empresas ou entidades de qualquer espécie (art. 12, § 5º); e, por fim, as transferências de capital, que são as dotações para investimentos ou inversões financeiras que outras pessoas de direito público ou privado devam realizar, independentemente de contraprestação direta em bens ou serviços. No caso dessas transferências, elas constituem auxílios ou contribuições, segundo derivem da Lei de Orçamento ou de lei especialmente anterior, bem como as dotações para amortização da dívida pública.

\footnotetext{
${ }^{381}$ ZANCHIM, Kleber Luiz. Capítulo III - da despesa: arts. 12 a 21. In: CONTI, José Maurício (Coord.). Orçamentos públicos: a lei 4.320/1964 comentada, p. 71.

382 TORRES, Ricardo Lobo. Curso de direito financeiro e tributário, p. 195-196.
} 
Além da classificação econômica, os gastos públicos também podem ser classificados de acordo com sua periodicidade em: gastos ordinários ou extraordinários. Por intermédio dos gastos ordinários, como se deduz, busca-se atender às necessidades públicas estáveis, permanentes e periodicamente previstas no orçamento; os gastos extraordinários, por sua vez, têm como propósito satisfazer as necessidades públicas momentâneas, de caráter esporádico, bem como acidentais, imprevisíveis, como despesas decorrentes de guerra, comoção interna ou intestina, calamidade pública, que, por serem urgentes e inadiáveis, não podem esperar o processo prévio da autorização legal.

Por fim, Ricardo Lobo Torres ${ }^{383}$ acrescenta, ainda, que subsistam outros critérios, por exemplo, que os gastos públicos também podem ser distinguidos de acordo com a instituição que os realiza, ou seja, por meio de um critério institucional, no qual se leva em conta o órgão ou a instituição a quem se atribui a realização do gasto (Ministério, Secretaria, Departamento etc.); ou mediante um critério programático, em que a despesa é classificada de acordo com o programa governamental a que se destina (ensino, saúde, transporte etc.).

Com efeito, verifica-se que o conceito de despesa pública está atrelado à necessidade pública e que qualquer que seja a forma de satisfação utilizada é indispensável que esta preexista para que o gasto se realize justificadamente. A realização de toda despesa ou a assunção de qualquer obrigação pelo Estado e seus agentes devem, assim, estar previamente estabelecidas nas leis orçamentárias, sob pena de serem consideradas não autorizadas, irregulares e lesivas ao patrimônio público.

\subsubsection{A despesa pública e seu caráter vinculativo}

A despeito de este estudo divergir da posição prevalecente, a qual defende ter o orçamento caráter meramente autorizativo, não há como afastar a teoria que busca dar maior efetividade à previsão orçamentária.

\footnotetext{
${ }^{383}$ TORRES, Ricardo Lobo. Curso de direito financeiro e tributário, p. 196.
} 
A tese defendida por Paul Laband, seguida por grande parte dos estudiosos, de que o orçamento é uma lei meramente formal, há muito deixou de ter o apoio da melhor doutrina, como sinaliza Ricardo Lobo Torres ${ }^{384}$ :

\begin{abstract}
A teoria da lei formal se enfraqueceu nos últimos anos no Brasil, a exemplo do que acontecia nos Estados Unidos e em outros países, diante da emergência das normas constitucionais de vinculação da receita pública a despesas e fundos específicos (EC 14/1996, 17/1997, 27/2000, 29/2000, 30/2000, 37/2000, 42/2003 e 53/2006), da criação de tributos vinculados (contribuições previdenciárias, contribuições sociais exóticas para a seguridade social (PIS/COFINS, CSLL, CPMF) e contribuições de intervenção no domínio econômico) e as titulações criadas pelo Judiciário (precatórios, mandados de injunção e outras ações) para a garantia dos direitos fundamentais e do mínimo existencial. O enfraquecimento da teoria da lei formal caminhou paralelamente co a perda de substância do princípio da não-afetação e com a definição das despesas necessárias e dos efeitos da vinculação de recursos trazida pela Lei de Responsabilidade Fiscal (art. $8^{\circ}$, parágrafo único, e art. 17 da LC 101/2000), tudo o que ampliou o papel do Judiciário e minimizou a discricionariedade dos poderes políticos (Legislativo e Executivo).
\end{abstract}

$\mathrm{Na}$ Espanha, antes mesmo da promulgação da Constituição Federal brasileira de 1988, Álvaro Rodríguez Bereijo já mostrava ser adepto do pensamento de Sainz de Bujanda, ao afirmar que "a proibição de que pelo o orçamento se crie ou modifique o ordenamento jurídico vigente não constitui uma confirmação positiva da natureza formal da lei orçamentária"385.

No Brasil, Regis Fernandes de Oliveira ${ }^{386}$ foi taxativo ao afirmar que as despesas devem ser efetuadas de acordo com a previsão orçamentária por representar os anseios da sociedade:

\begin{abstract}
A título de conclusão, pode-se afirmar que o orçamento é impositivo, não deixando margem a manobras, titubeios ou qualquer tergiversação do Governo, a pretexto de utilizá-lo como meramente autorizativo. Contém autorizações, com certeza, na arrecadação, mas as despesas devem ser efetuadas de acordo com o que foi determinado na lei orçamentária.
\end{abstract}

Caso contrário, como já se disse, teremos a desmoralização do Congresso que de nada serviria. Para que aprovar a lei orçamentária, se ela não será cumprida? Ao

\footnotetext{
${ }^{384}$ TORRES, Ricardo Lobo. Tratado de direito constitucional financeiro e tributário, p. 97.

${ }^{385}$ BEREIJO, Álvaro Rodríguez. La configuración constitucional de las leyes de presupuestos generales del estado. Valadolid: Lex Nova, 1988. p. 31.

386 OLIVEIRA, Regis Fernandes de. Deve o orçamento ser cumprido? Jus Navegandi, Teresina, ano 9, n. 672, 8 maio 2005. Disponível em: 〈http://jus.com.br/revista/texto/6698/deve-o-orcamento-ser-cumprido〉. Acesso em: 22 abr. 2013.
} 
contrário, diante da Lei de Responsabilidade Fiscal, o orçamento deve ser executado tal como aprovado, pois, qualquer desvio envolve a responsabilidade do Chefe do Executivo.

Ao democratizar o processo legislativo do orçamento, restou conferido ao Poder Legislativo a prerrogativa de estabelecer as prioridades que vão condicionar a elaboração do projeto da lei orçamentária anual, o que se dá, como já assinalado, pela lei de diretrizes orçamentárias. Embora essa lei seja de iniciativa do Poder Executivo, o qual está adstrito a observar as indicações contidas no plano plurianual, deve ser aprovada pelo Legislativo, que detém ampla liberdade de emendá-la, até mesmo modificando as prioridades indicadas pelo Executivo.

É o que se verifica também com a edição da Lei Complementar $n^{0} 101$, de 4 de maio de 2000, conhecida como Lei de Responsabilidade Fiscal, a qual determina que os mandamentos da Lei $\mathrm{n}^{\mathrm{o}}$ 4.320/1964 sejam interpretados em consonância com os preceitos da Constituição Federal e impõe ao Administrador a obrigação de realizar uma gestão fiscal responsável, pressupondo uma atuação planejada e transparente, capaz de assegurar o equilíbrio das contas públicas, e que disciplina os diferentes orçamentos, a gestão financeira, o crédito público e a fiscalização de todas as atividades relacionadas ao gasto do dinheiro público ${ }^{387}$.

A necessidade de se conferir maior responsabilidade ao cumprimento do quanto estatuído no orçamento, afastando a pretensão de se afirmar que as dotações orçamentárias são desprovidas de qualquer caráter vinculativo, ganha força com a leitura do art. 21, inc. IX, da CF/1988, o qual atribui à União Federal a competência para "elaborar e executar planos nacionais e regionais de ordenação do território e de desenvolvimento econômico e social".

Não obstante, e conforme abordado anteriormente, o orçamento configura-se como verdadeiro plano de atuação do Estado, constituindo "a expressão da política geral do Estado" e, mais do que mero programa, "é um ato de direção política, pois determina a vontade estatal por meio de um conjunto de medidas coordenadas" 388 .

\footnotetext{
${ }^{387}$ DALLARI, Adilson Abreu. Orçamento impositivo. In: CONTI, José Maurício; SCAFF, Fernando Facury. (Coord.). Orçamentos públicos e direito financeiro, p. 312.

${ }^{388}$ BERCOVICI, Gilberto. Constituição econômica e desenvolvimento: uma leitura a partir da Constituição de 1988, p. 69.
} 
Para tanto, faz-se necessário dar maior efetividade ao planejamento das ações governamentais de longo prazo, minimizar a discricionariedade e a influência das paixões, evitando desperdícios e impor um empreendimento do dinheiro público mais eficiente, de modo a melhor atender aos anseios da sociedade. Afinal, é por meio do orçamento que a Administração Pública cumpre suas funções, regula e intervém no campo social e econômico.

Em face da evolução e do tratamento dado à matéria pela Constituição Federal vigente, percebe-se nitidamente que as dotações orçamentárias deixaram de ser meras autorizações, estando vinculadas à execução de determinados projetos ou programas, determinantes para a Administração e para a sociedade, o que é esclarecido com propriedade por José Maurício Conti ${ }^{389}$, ao sintetizar a evolução do orçamento:

Inicialmente, esses incipientes orçamentos públicos eram documentos que tinham o caráter de peças contábeis, em que se faziam as previsões de receitas e autorizações de despesas para um determinado período - o exercício financeiro. Essa é, em síntese, o que se denomina concepção clássica do orçamento.

As necessidades da Administração Pública, aliadas ao desenvolvimento das técnicas orçamentárias, foram aos poucos modificando a concepção clássica do orçamento público, fazendo com que assumisse uma função importante na condução das políticas públicas. Vários fatores influíram nessa tendência, destacando-se o intenso intervencionismo estatal nas atividades econômicas.

O autor ${ }^{390}$ prossegue em seu relato:

O orçamento torna-se um instrumento fundamental no planejamento e na programação da atividade econômica do Governo, adquirindo, como bem ressalta Giuliani Fonrouge, uma condição dinâmica, e tornando-se "un instrumento mediante el cual el Estado actúa sobre la economia".

As técnicas e os conceitos orçamentários modernos refletem essa nova função dos orçamentos públicos, surgindo os conceitos de orçamento-programa, orçamento de desempenho (performance budget) e PPBS (planing, programming and budgeting system), que, embora não tenha distinção nítida entre si, demonstram que o orçamento, inequivocamente, abandona sua concepção clássica para assumir a condição de instrumento de ação governamental.

${ }^{389}$ CONTI, José Maurício. A autonomia financeira do poder judiciário. São Paulo: MP Editora, 2006. p. 57.

${ }^{390}$ Ibidem, p. 58. 
Ainda que as considerações apresentadas bastem para reconhecer o caráter impositivo do orçamento, verifica-se que a controvérsia ganha mais força se colocada na disputa entre o Executivo e o Legislativo, no que concerne à liberação de verbas das emendas de deputados e senadores pelo Executivo, o qual, diante do caráter meramente autorizativo da lei orçamentária, motivou a apresentação de várias proposições legislativas que tendem a introduzir a figura do denominado orçamento impositivo no ordenamento brasileiro, como aponta Luís Otávio Barroso da Graça ${ }^{391}$ :

\begin{abstract}
Uma questão que tem hoje recebido severas críticas está relacionada à liberação de verbas das emendas de deputados e senadores pelo Poder Executivo. Como este não tem obrigação de executar determinadas ações, têm os parlamentares que solicitar o atendimento dos projetos para os quais destinaram recursos por meio de emendas. Alguns entendem que tais solicitações, conhecidas por "barganhas", retiram autonomia do Poder Legislativo e o colocam em situação de inferioridade frente ao Executivo. A adoção do orçamento impositivo (no todo ou em parte), portanto, tenderia a resolver essa situação, na medida em que não restaria ao Poder Executivo outra solução que não a de executar as emendas parlamentares.
\end{abstract}

Uma das primeiras propostas legislativas que abordou o caráter impositivo do orçamento, ainda que indiretamente, foi o Projeto de Lei Complementar de $n^{0}$ 135/1996. Destinado a promover a alteração da Lei $\mathrm{n}^{\mathrm{o}}$ 4.320/1964, detinha como fím precípuo regulamentar o art. 165, § 9oㅡㄹ da CF/1988, e atribuir certo caráter de obrigatoriedade à execução orçamentária, impondo ao Poder Executivo, caso pretendesse deixar de executar o quanto previsto na lei orçamentária, a obrigatoriedade de encaminhar ao Congresso Nacional um projeto de lei de anulação, a fim de desvincular a receita e a obrigatoriedade do gasto.

Tramitam no Congresso brasileiro, também, várias outras propostas de emendas constitucionais, cujo intuito é impor a aplicação de determinados percentuais das receitas em ações e serviços; restringir o contingenciamento de emendas individuais dos parlamentares pelo Poder Executivo; estabelecer limite para abertura de créditos

${ }^{391}$ GRAÇA, Luís Otávio Barroso da. Orçamento impositivo: uma análise à luz da economia política. 2003. 79 f. Dissertação (Mestrado em Economia do Setor Público) - Universidade de Brasília - UnB, 2003 , f. 11/12. Disponível em: <http://www2.senado.gov.br/bdsf/item/id/88438>. Acesso em: 22 abr. 2013. 
extraordinários e, além disso, promover a implementação de um suposto orçamento impositivo $^{392}$.

Ainda que restrito a uma parcela inferior a $10 \%$ do orçamento, pois todo o resto já detém destinação certa, ou melhor, já se encontra vinculado a determinada atividade, investimento ou realização de despesa como gastos com pessoal e pagamento da dívida pública (art. 9º,$\S 2^{\circ}$, da LC 101/2000), muito se discute acerca da implementação ou não do denominado orçamento impositivo, o que recairá sobre as despesas ditas discricionárias.

Além das Propostas de Emendas Constitucionais anteriormente citadas, restou aprovada em 12 de novembro de 2013 pelo Senado Federal e em primeiro turno pela Câmara dos Deputados, em 6 de maio de 2014, a PEC 22A/2000, então conhecida como "Proposta de Emenda à Constituição do Orçamento Impositivo". Apresentada originariamente pelo então senador Antonio Carlos Magalhães, no ano de 2000, os senadores e líderes governistas preveem que ela possibilitará à área da saúde orçamento de pelo menos R \$ 64 bilhões a mais até 2018. Essa PEC estabelece, ainda, a obrigatoriedade de executar as emendas parlamentares até o limite de 1,2\% da receita corrente líquida (RCL) do exercício anterior; desse total, 50\%, ou seja, 0,6\% da RCL deverão ser aplicados na área de saúde.

Antes da aprovação da PEC 22A/2000, José Maurício Conti, ao comentar as declarações prestadas pelo então Presidente da Câmara dos Deputados, Henrique Eduardo Alves, que manifestava sua intenção em acelerar a tramitação da Proposta de Emenda Constitucional $n^{\mathrm{o}} 565 / 2006^{393}$, já externou sua posição, corroborando com a tese defendida por Regis Fernandes de Oliveira ${ }^{394}$, nos seguintes termos:

\footnotetext{
Mas, independentemente das razões que a justificam, e até do fato de os interesses que a sustentam terem dimensões menores do que a questão jurídica de fundo, o fato é que a aprovação desta emenda constitucional promoverá um importante avanço no sentido de se fazer respeitar a lei orçamentária. Colaborará decisivamente para lhe conferir maior eficácia e credibilidade - o que já é uma
}

\footnotetext{
392 PEC 236/2012; PEC 201/2012; PEC 182/2012; PEC 156/2012; PEC 152/2012; PEC 20/2011; PEC 417/2009; PEC 321/2009; PEC 281/2008; PEC 127/2007; PEC/102/2007; PEC 96/2007; PEC 46/2007; PEC 565/2006; PEC 480/2005; PEC 385/2005; PEC 229/2204 etc. Disponível em: 〈http://www2.camara.leg.br/〉. Acesso em: 14 maio 2013.

393 ALVES, Henrique Eduardo. Orçamento respeitosamente impositivo. Folha de S. Paulo. São Paulo, 14 abr. 2013. Seção Tendências/Debates, p. A3.

${ }^{394}$ CONTI, José Maurício. Orçamento impositivo é avanço para administração. Consultor Jurídico, 7 maio 2013. Disponível em: <http://conjur.com.br/2013-maio-07/contas-vista-orcamento-impositivo-avancoadminstracao>. Acesso em: 6 out. 2014.
} 
evolução para o que se espera de um futuro próximo, que é a máxima "impositividade" do orçamento -, e contribuirá para o respeito à democracia, à vontade popular expressa por ocasião da aprovação da lei orçamentária, à independência e autonomia dos poderes e ao planejamento e gestão eficiente da administração pública, elementos essenciais para o desenvolvimento econômico e social.

Aqueles que se contrapõem ao orçamento impositivo, por sua vez, argumentam que este não é "uma fórmula garantidora das previsões que o contém, isto é, o orçamento não pode garantir que as previsões orçamentárias sejam realizadas concretamente. Estas dependem do desempenho econômico e de decisões políticas que a confirmem" ${ }^{395}$.

Mesmo que se alegue que o orçamento não pode garantir que as previsões orçamentárias sejam realizadas concretamente ou que estaria reduzida a discricionariedade, o Executivo deterá instrumentos capazes de afastar eventual dotação que se mostre impossível de se realizar, bastando, para tanto, justificar sua pretensão ao Legislativo que, diante do caso em concreto, não terá como se opor.

Nota-se, assim, que o orçamento detém um caráter vinculante no que toca às dotações orçamentárias, devendo-se deixar de lado os costumes arraigados, sedimentados há longo tempo, a fim de que as despesas sejam realizadas como previsto na lei orçamentária.

\subsubsection{A previsibilidade do gasto público como fator de indução e regulação da atividade econômica}

Já se disse, linhas atrás, que o Poder Público elege, politicamente, como atenderá às necessidades públicas e, assim, como realizará o gasto público. Além disso, também se esclareceu que toda despesa deve estar previamente estabelecida em lei, sob pena de ser considerada não autorizada, irregular e lesiva ao patrimônio público, bem como se defendeu ser necessário conferir maior responsabilidade ao cumprimento do quanto

\footnotetext{
${ }^{395}$ SEGUNDO, Rinaldo. Breves considerações sobre o orçamento público. Jus Navegandi, 2002. Disponível em: 〈http://jus.com.br/revista/texto/4505/breves-consideracoes-sobre-o-orcamento-publico〉. Acesso em: 30 jun. 2013.
} 
estatuído no orçamento e afastar a pretensão de se afirmar que as dotações orçamentárias são desprovidas de qualquer caráter vinculativo.

Com apoio nessas premissas, especialmente no tocante à previsibilidade da despesa pública, pode-se dizer que em uma economia em que constantemente são lançados como objetivos o pleno emprego, a estabilidade dos preços, a expansão da produção e a melhor distribuição de renda, essa previsibilidade exerce forte influência e deveria ser tratada com mais responsabilidade.

A propósito, como Héctor Belisario Villegas ${ }^{396}$ salienta:

\begin{abstract}
Mediante el gasto público el Estado se moviliza para atender las necesidades de la población por medio de los servicios públicos, cuyo destino es la cobertura de las necesidades públicas. Pero también el Estado puede satisfacer dichas necesidades con prescindencia de los servicios públicos y utilizando los efectos que "en sí mismos" los gastos públicos provocan en la economía nacional, atento a su importancia cuantitativa y cualitativa (p. ej.: un incremento considerable en la cuantía del gasto público puede obrar como reactivador de una economía en recesión con prescindencia del destino del gasto).
\end{abstract}

Não por menos, valendo-se da teoria proposta por John Maynard Keynes, e de forma pontual, Alejandro Ramirez Cardona ${ }^{397}$ assinala que o gasto público, assim como o gasto realizado pelo setor privado, é capaz de produzir efeitos multiplicadores. Por meio do gasto público verifica-se incremento na renda nacional e, consequentemente, aumento do consumo e do investimento na economia.

Nesse sentido, recorda Benvenuto Griziotti ${ }^{398}$ que o Estado passou dos gastos extremamente vinculados à tutela jurídica e à defesa militar, para os gastos gerais favoráveis ao desenvolvimento demográfico e à prosperidade da nação.

Para Fábio Nusdeo ${ }^{399}$, o governo, nesse caso, gasta de duas formas: “a) absorvendo mão de obra ainda não empregada pelas empresas; e b) investindo parte dos recursos em obras ou serviços públicos, os quais, por seu turno, incrementariam o nível de atividade das empresas, levando-as a contratar mais membros das famílias".

\footnotetext{
${ }^{396}$ VILLEGAS, Héctor Belisario. Curso de finanzas, derecho financiero y tributario, 9. ed., p. 32.

${ }^{397}$ CARDONA, Alejandro Ramirez. Sistema de hacienda pública, p. 160.

${ }^{398}$ GRIZIOTTI, Benvenuto. Principios de ciencia de las finanzas, p. 66.

${ }^{399}$ NUSDEO, Fábio. Curso de economia: introdução ao direito econômico, p. 291.
} 
O Estado atua, mediante a realização da despesa pública, como indutor da economia, nela intervindo e estimulando as empresas a melhorarem ou expandirem sua capacidade produtiva, o que se dará com a realização de investimentos em máquinas, instalações, equipamentos, ampliação de estoques, contratação de novos funcionários etc. $^{400}$.

Com base no exposto, torna-se possível deduzir a razão pela qual a Lei $\mathrm{n}^{\mathrm{o}}$ 4.320/1964 estabelece um critério de divisão preponderantemente econômico, em que as despesas correntes refletem "a ideia de 'aparelhamento do Estado', ou crescimento da máquina pública, enquanto as despesas de capital são vistas como fator de promoção do desenvolvimento econômico" 401 .

Enquanto as despesas correntes são vistas com preocupação por refletirem os gastos do Estado e exercerem influência direta na apuração do superávit primário ${ }^{402}$; as despesas de capital adquirem cunho "desenvolvimentista", pois fomentam o crescimento econômico e melhoram a capacidade do país de honrar suas dívidas ${ }^{403}$.

Ao prever o quanto e de que forma gastará os recursos públicos, valendo-se do planejamento como instrumento ou ferramenta para alcançar seu fim único - o interesse público -, o Estado traça seus objetivos e metas prioritárias, e define os modos operacionais com que pretende alcançá-los. Em suma, o Estado apresenta à sociedade e, portanto, ao domínio econômico, seu plano de atuação, influenciando o domínio econômico a tomar decisões positivas ou negativas.

Como bem recorda Kleber Luiz Zanchim ${ }^{404}$, o PPI foi utilizado pela primeira vez em 2009, para ajustar as metas de superávit primário e, com a redução da arrecadação tributária, em face da crise financeira internacional, o governo optou por realizar investimentos com o propósito anticíclico.

Nesse aspecto, são pertinentes as considerações de Richard A. Musgrave ${ }^{405}$ que, ao abordar os aspectos relativos às compras públicas e, portanto, decorrentes da execução do

\footnotetext{
${ }^{400}$ NUSDEO, Fábio. Curso de economia: introdução ao direito econômico, p. 293.

401 ZANCHIM, Kleber Luiz. Capítulo III - da despesa: arts. 12 a 21. In: CONTI, José Maurício Coord.). Orçamentos públicos: a lei 4.320/1964 comentada, p. 72.

${ }^{402} \mathrm{O}$ superávit primário, a grosso modo, é composto pelo saldo positivo entre receitas e despesas, excluídas as receitas de juros e capital e as despesas com juros, amortizações e correções da dívida pública.

${ }^{403}$ ZANCHIM, Kleber Luiz. Op. cit., p. 73.

${ }^{404}$ Ibidem, loc. cit..

${ }^{405}$ MUSGRAVE, Richard A. Teoria das finanças públicas. São Paulo: Atlas, 1974. v. 2, p. 75.
} 
orçamento, cita a possibilidade de o governo conceder contratos a pequenos fornecedores, ou, então, aos que se localizem em certas áreas, ainda que seus preços sejam maiores, refletindo, a política de compra, uma combinação de objetivos que envolvem considerações distributivas sociais ou de defesa.

Com isso, verifica-se que o Estado intervém, ainda que indiretamente, na economia, induzindo-a a agir ou deixar de agir de acordo com o que for mais importante para a sociedade em dado momento. Essa interferência, como assinala Regis Fernandes de Oliveira $^{406}$, deve dar-se de forma objetiva, pois:

Em termos de economia interna, o que vale é assentar sua decisão no interior de um conhecimento exaustivo da realidade brasileira e induzir a economia naquilo que for mais importante naquele dado momento histórico.

As despesas atenderão, assim, a realidades econômicas objetivas. Sem dúvida que a tomada de decisão é subjetiva, mas cercada pelo máximo de objetividade possível, ou seja, informações sobre o mercado, como ele está funcionando, quais as paralelas imprescindíveis para o encaminhamento econômico do país.

Tem-se, com isso, que a previsão das despesas públicas influi diretamente sobre os rumos da economia de um país, consistindo importante instrumento de redistribuição de renda, de estabilização econômica e de incremento da renda nacional; ela exerce forte influência sobre os aspectos mais essenciais, como o emprego e a renda, o consumo e o desenvolvimento ${ }^{407}$.

Logo, atrelada ao planejamento orçamentário, o gasto público tendente à realização das políticas públicas e, com isso, a satisfação dos interesses públicos, deve ser adequadamente estruturado e se dar em consonância com os objetivos e a capacidade da iniciativa privada em determinado momento histórico, sob pena de impedir ou reduzir o crescimento econômico almejado.

Novamente mostra-se de salutar relevância a adoção de um planejamento responsável e seu fiel cumprimento, de modo a assegurar a adoção de medidas corretivas decorrentes das reações do mercado às intenções do próprio Estado ou provocadas por

\footnotetext{
${ }^{406}$ OLIVEIRA, Regis Fernandes de. Gastos públicos, p. 18.

${ }^{407}$ VILLEGAS, Héctor Belisario. Curso de finanzas, derecho financiero y tributario, 9. ed., p. 34.
} 
fatores externos e imprevisíveis, como, por exemplo, guerras, crises econômicas, medidas de proteção ou restritivas de mercado impostas por outros países.

\subsection{As subvenções econômicas}

Apresentado esse breve exame dos contornos envolvendo as despesas públicas, seu caráter vinculativo e as principais implicações para o domínio econômico, faz-se pertinente proceder à análise das subvenções econômicas, pois implicam custos e, consequentemente, gasto para o Erário.

Essas subvenções, afinal, constituem um gasto público destinado a auxiliar em termos financeiros entidades públicas e privadas, devendo obrigatoriamente estar prevista no orçamento. Além disso, pretende-se demonstrar como sua utilização tem se dado e os principais problemas decorrentes do emprego deste importante instrumento sem critérios e planejamento.

\subsubsection{Conceito, distinções e características}

O instituto da subvenção sempre encontrou, no campo jurídico, considerável diversidade de conceitos e aplicações. Diante da ausência de conteúdo específico, muitos ainda se valem do termo como sinônimo de subsídio ou de renúncia de receita, empregando-os como palavras identificadoras de auxílio, ajuda e até mesmo socorro financeiro, sem precisão terminológica alguma.

A Constituição Federal brasileira faz menção ao instituto da subvenção em vários dispositivos (arts. 19, I, 70, 71 e 190, § $2^{\circ}$ ), no entanto, é com o advento da Emenda 
Constitucional $\mathrm{n}^{\mathrm{o}}$ 19/1998 408 , de 4 de junho de 1998, que se tornou possível distingui-la dos subsídios, reconhecendo-a como sendo a remuneração paga aos agentes políticos, conforme se extrai do disposto no art. $39, \S 4^{\underline{o}}$, da $\mathrm{CF} / 1988$ colacionado a seguir:

\begin{abstract}
O membro de Poder, o detentor de mandato eletivo, os Ministros de Estado, os Secretários Estaduais e Municipais, serão remunerados exclusivamente de subsídio fixado em parcela única, vedado o acréscimo de qualquer gratificação, adicional, abono, prêmio, verba de representação ou qualquer outra espécie remuneratória [...]. (sem grifo no original)
\end{abstract}

Tem-se que o subsídio "é a denominação atribuída à forma remuneratória de certos cargos, por força da qual a retribuição que lhes concerne se efetua por meio dos pagamentos mensais de parcelas únicas, ou seja, indivisas e insuscetíveis de aditamentos ou acréscimos de qualquer espécie" ${ }^{409}$.

Além de deter como pressuposto o pagamento da remuneração devida aos agentes políticos (art. 37, XI, da CF/1988), os subsídios, ao contrário das subvenções, de um lado, consistem em um auxílio de caráter não orçamentário e, de outro, conforme Gaston Jèze ${ }^{410}$, podem ser entendidos por subvenção, como sendo:

[...] una suma de dinero que se entrega periódicamente o en su totalidad y que tiene por objeto facilitar el funcionamiento de la obra o establecimiento privado que persigue una finalidad de interés general. Esta subvención no transforma dicha obra o estabelecimiento en servicio público, ya que sigue siendo privado.

Com efeito, constitui a subvenção um verdadeiro auxílio financeiro que deve estar previsto no orçamento público e que se destina a ajudar entidades públicas ou particulares a desenvolver atividades assistenciais, culturais ou empresariais ${ }^{411}$.

A propósito, o sistema financeiro nacional, de acordo com o $\S 3^{\circ}$, do art. 12 da Lei $\mathrm{n}^{\mathrm{o}}$ 4.320/1964, distingue as subvenções em duas espécies: (i) as sociais, especificamente destinadas a instituições públicas e/ou privadas de caráter assistencial ou cultural, sem fins

\footnotetext{
${ }^{408}$ Alterou, dentre outros, o $\S 2^{\circ}$ do art. 27 da CF/1988, o qual passou a ter a seguinte redação: "§ $2^{\circ}$. O subsídio dos Deputados Estaduais será fixado por Lei de iniciativa da Assembleia Legislativa, na razão de, no máximo, setenta e cinco por cento daquele estabelecido, em espécie, para os Deputados Federais, observado o que dispõem os arts. $39, \S 4^{\circ}, 57, \S 7^{\circ}, 150$, II, 153 , III, e $153, \S 2^{\circ}$, I".

${ }^{409}$ MELLO, Celso Antônio Bandeira de. Curso de direito administrativo, p. 272.

${ }^{410}$ JÈZE, Gaston. Principios generales del derecho administrativo, p. 53.

${ }^{411}$ OLIVEIRA, Regis Fernandes de. Curso de direito financeiro, p. 445.
} 
lucrativos; e (ii) as econômicas, destinadas a "empresas públicas" ou privadas de caráter industrial, comercial, agrícola ou pastoril.

Verifica-se, assim, que as subvenções econômicas adquirem e constituem verdadeiro instrumento de política financeira, definido de acordo com as transferências ou prestações monetárias prestadas em favor de entidades privadas pelo setor público, que, ao invés de esperar destas uma contraprestação na economia de mercado, ou seja, que os agentes econômicos ajam de forma livre, com pouca ou nenhuma intervenção estatal, tem por expectativa, geralmente, o fomento de determinado tipo de comportamento.

Compreende-se, assim, que as subvenções econômicas, em específico, constituem um auxílio financeiro destinado a ajudar empresas públicas e privadas no desenvolvimento de suas atividades e têm como fator determinante a realização ou incentivo à prática de determinado ato.

O art. 19 da Lei $\mathrm{n}^{\mathrm{o}}$ 4.320/1964 pró́be o Estado de prestar ajuda financeira a empresas cujas atividades tenham fins lucrativos, mas também o autoriza a prestar ajuda financeira a empresas sem fins lucrativos quando se tratar de subvenções cuja concessão tenha sido expressamente autorizada em lei especial. Em suma, a subvenção econômica pode ser concedida em favor de empresas públicas e privadas, com ou sem fins lucrativos, sendo certo que nesta última hipótese deve ser implementada por lei específica.

As subvenções econômicas caracterizam-se, assim, por consistirem um auxílio financeiro prestado pelo Estado; destinarem-se a fomentar a atividade de empresas públicas e privadas, de caráter industrial, comercial, agrícola ou pastoril, com ou sem fins lucrativos.

Ocorre que, embora sejam aceitas naturalmente como algo que constitui uma realidade da atividade econômica, muitos deixam de levar em consideração as diversas formas e modos de manifestação das subvenções econômicas, o que contribui para a ausência de controle e mensuração dos resultados pretendidos, suas implicações orçamentárias, que vão desde o aumento de tributos à qualidade do gasto público, e, ainda, sua incidência em face do funcionamento do processo econômico. 


\subsubsection{Relevância e importância das subvenções econômicas}

As subvenções econômicas constituem verdadeiro instrumento de intervenção e fomento à economia, destinados, conforme salientado, a servir de auxílio financeiro a empresas públicas e privadas de caráter industrial, comercial, agrícola ou pastoril ${ }^{412}$ e têm como propósito, de acordo com o art. 18 da Lei $\mathrm{n}^{\mathrm{o}}$ 4.320/1964: (i) a cobertura dos déficits de manutenção das empresas públicas; (ii) a cobertura das diferenças entre os preços de mercado e os preços de revenda, pelo Governo, de gêneros alimentícios ou outros materiais; e (iii) o pagamento de bonificações a produtores de determinados gêneros ou materiais.

Caracteriza-se como incentivo financeiro, já que auxilia no financiamento, orienta e induz o produtor a determinada atividade. É preciso esclarecer, que os beneficiários das subvenções econômicas são apenas empresas e, portanto, pessoas jurídicas de direito privado, dentre as quais não se incluem as autarquias ${ }^{413}$ e fundações públicas ${ }^{414}$, por serem consideradas entes não empresariais de direito público.

Além das considerações apresentadas, é preciso ressaltar que o caput do art. 18 da Lei em comento, ao fazer menção às “empresas públicas, de natureza autárquica”, deve ser interpretado em consonância com o Decreto-lei n⿳丷ㄹ 200, de 25 de fevereiro de 1967, o qual distinguiu a figura das autarquias, empresas públicas, sociedades de economia mista e fundações públicas, inexistindo, no regime brasileiro atual, a figura da "empresa pública de natureza autárquica", mencionada em referido dispositivo legal.

\footnotetext{
${ }^{412}$ Art. $12, \S 3^{\circ}$, inc. II, da Lei $\mathrm{n}^{\mathrm{o}} 4.320 / 1964$.

413 As autarquias são definidas como sendo "pessoas jurídicas de Direito Público de capacidade exclusivamente administrativa" (MELLO, Celso Antônio Bandeira de. Curso de direito administrativo, $\mathrm{p}$ 160).

${ }^{414}$ De acordo com o Decreto-lei $\mathrm{n}^{\mathbf{0}}$ 200, com a alteração introduzida pela Lei $\mathrm{n}^{\mathbf{o}} 7.596$, de 10 de abril de 1987, compreende-se por fundação pública "a entidades dotada de personalidade jurídica de Direito Privado, sem fins lucrativos, criada em virtude de autorização legislativa, para o desenvolvimento de atividades que não exijam execução por órgãos ou entidades de Direito Público, com autonomia administrativa, patrimônio gerido pelos respectivos órgãos de direção, e funcionamento custeado por recursos da União e de outras fontes". Para Celso Antônio Bandeira de Mello, "É absolutamente incorreta a afirmação normativa de que as fundações públicas são pessoas de Direito Privado. Na verdade, são pessoas de Direito Público [...]. O que se passou, entretanto, no Direito brasileiro é que foram criadas inúmeras pessoas designadas como 'fundações', com atribuições nitidamente públicas, e que, sob o este aspecto, em nada se distinguem das autarquias. O regime delas estaria inevitavelmente atrelando-as às limitações e controles próprios das pessoas de Direito Público. Entretanto, foram batizadas de pessoas de Direito Privado apenas para se evadirem destes controles moralizadores ou, então, para permitir que seus agentes acumulassem cargos e empregos, o que lhes seria vedado se fossem reconhecidas como pessoas de Direito Público" (ibidem, p. 184).
} 
Com isso, e de acordo com o caput do art. 18 da Lei n ${ }^{\circ} 4.320 / 1964$, somente as empresas privadas, públicas e sociedades de economia mista podem receber transferências correntes para enfrentar seus déficits de manutenção, ou seja, despesas de custeio e não de capital, as quais se subdividem em despesas de investimentos, de inversões financeiras e transferências de capital, nos termos do art. 12 da mencionada Lei ${ }^{415}$.

Feitas essas considerações, tem-se que na primeira hipótese, a qual consiste na concessão de subvenção para a "cobertura dos déficits de manutenção das empresas públicas", ou seja, aquelas que se originam da diferença negativa entre receitas e despesas correntes, é excepcional ${ }^{416}$ e limitada a empresas controladas pelo Poder Público.

Nas demais hipóteses, consagradas nas alíneas $a$ e $b$ do parágrafo único do art. 18, é que são destinadas a empresas privadas, as quais, como já salientado, podem receber ajuda financeira ainda que detenham fins lucrativos, mas tão somente se contar com autorização de lei especial, nos termos do art. 19.

Logo, a subvenção econômica, se não concedida a empresa sem fins lucrativos, só é possível mediante expressa previsão legal, sem a qual inexistirá a possibilidade do ato liberatório, não se tratando, portanto, de mera liberalidade, pois condicionado está ao cumprimento de diversos requisitos, dentre os quais aqueles expressos no Decreto $\mathrm{n}^{\mathrm{o}}$ 93.872/1986: (i) concessão prevista em lei especial (art. 61); (ii) prévia comprovação de regularidade fiscal do beneficiário (art. 62); (iii) comprovação do bom e regular emprego dos recursos percebidos; (iv) comprovação dos resultados alcançados (art. 66); e (v) que seu emprego atenda ao ônus ou encargo assumido pela União (art. 12, § $6^{0}$ da Lei $n^{\mathrm{o}}$ 4.320/1964).

Em termos constitucionais, verifica-se a existência de uma única vedação no que toca à possibilidade jurídica de subvencionar, adstrita aos cultos religiosos ou igrejas (art. 19, I, da CF/1988). Nesse caso, levou-se em consideração o fato de o Brasil ser uma República Federativa leiga ou laica, uma vez que há separação total entre Estado e Igreja e, inexistindo religião oficial, destaca-se a vedação constitucional de instituição de impostos

415 O Tribunal de Contas da União (TCU) já se manifestou nesse sentido ao impugnar a aplicação de subvenção em despesas de capital: TCs-575.664/1995-2, Acórdão nº 556/2000-1 a Câmara; 575.518/1995-2,

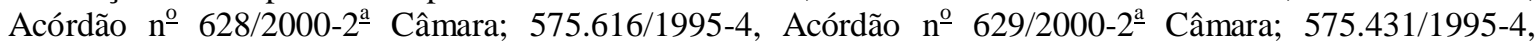

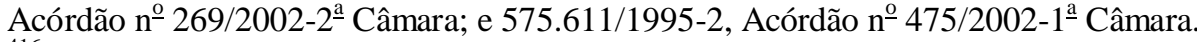

${ }^{416}$ OLIVEIRA, Regis Fernandes de. Curso de direito financeiro, p. 446. 
pela União, Estados, Distrito Federal e Municípios sobre templos de qualquer culto (art. 150 , VI, $b$, da CF/1988).

Em face do exposto, conclui-se que qualquer empresa pública ou privada pode perceber auxílio financeiro do Estado, desde que atendidos e preenchidos os requisitos impostos por lei, independentemente de contraprestação direta em bens ou serviços.

\subsubsection{Os problemas decorrentes de uma política subvencionista e a necessidade de se empreender maior controle e fiscalização}

Como anota Gaston Jèze, politicamente, a concessão de subvenção pode ser muito vantajosa para a Administração: "infaliblemente, la subvención cuesta menos que la trasformación en servicio público propriamente dicho. En primer lugar, una parte de los gastos seguirá a cargo de la obra o establecimiento; la Administración asumirá sólo una parte de ellos"417.

Nesse aspecto, Ricardo Lobo Torres anota com precisão que, por meio da política de privatizações, o Estado conseguiu transferir para a iniciativa privada amplos setores das empresas estatais, o que consistiu na primeira grande reforma tendente a permitir o florescimento do Estado Fiscal ${ }^{418}$.

Com efeito, ao se levar em consideração alguns dados econômicos, os quais foram condicionantes para o alcance de certa estabilidade macroeconômica e institucional, a criação e a instituição de qualquer política de inclusão social e até mesmo a melhoria da distribuição de renda, será possível notar que as subvenções econômicas adquiriram significativa importância e, em muitos casos, tornaram-se indispensáveis para determinados setores da economia.

\footnotetext{
${ }^{417}$ JÈZE, Gaston. Principios generales del derecho administrativo, p. 53

418 TORRES, Ricardo Lobo. Tratado de direito constitucional, financeiro e tributário: o orçamento na Constituição, p. 44.
} 
Ainda que a Lei $n^{0}$ 8.429, de 2 de junho de 1992 - conhecida como Lei de Improbidade Administrativa -, imponha sanções aos beneficiários ${ }^{419}$, não restam dúvidas que o Estado tem se valido das subvenções econômicas para atingir os objetivos apontados há pouco, utilizando-as como método de intervenção no domínio econômico.

É o que se extrai da Lei $\mathrm{n}^{\mathrm{o}}$ 12.096/2009, por meio da qual a União Federal autoriza a concessão de subvenção econômica no valor correspondente a $\mathrm{R} \$ 402$ bilhões ao Banco Nacional de Desenvolvimento Econômico e Social (BNDES), para operações de financiamento destinadas à aquisição e produção de bens de capital e à inovação tecnológica ${ }^{420}$; do Decreto $\mathrm{n}^{\mathrm{o}}$ 8.079, de 20 de agosto de 2013, alterado pelo Decreto $\mathrm{n}^{\underline{\mathrm{o}}}$ 8.183, de 17 de janeiro de 2014 e que regulamenta a Medida Provisória no 615, de 17 de maio de 2013, concedendo até R \$ 148 milhões para o pagamento de subvenção econômica extraordinária aos produtores fornecedores independentes de cana de açúcar e às unidades industriais produtoras de etanol combustível que desenvolvam suas atividades na Região Nordeste, referente à produção da safra 2011/2012 e em tantas outras.

Em específico no setor agropecuário, nota-se maior incidência de concessão de subvenções $^{421}$. A análise dos custos fiscais envolvendo as subvenções econômicas

\footnotetext{
${ }^{419}$ Conforme disposto a seguir: "Art. $1^{\circ}$. Os atos de improbidade praticados por qualquer agente público, servidor ou não, contra a administração direta, indireta ou fundacional de qualquer dos Poderes da União, dos Estados, do Distrito Federal, dos Municípios, de Território, de empresa incorporada ao patrimônio público ou de entidade para cuja criação ou custeio o erário haja concorrido ou concorra com mais de cinquenta por cento do patrimônio ou da receita anual, serão punidos na forma desta lei.

Parágrafo único. Estão também sujeitos às penalidades desta lei os atos de improbidade praticados contra o patrimônio de entidade que receba subvenção, benefício ou incentivo, fiscal ou creditício, de órgão público bem como daquelas para cuja criação ou custeio o erário haja concorrido ou concorra com menos de cinquenta por cento do patrimônio ou da receita anual, limitando-se, nestes casos, a sanção patrimonial à repercussão do ilícito sobre a contribuição dos cofres públicos." (sem grifo no original).

${ }^{420}$ Trata-se de subsídio governamental dado aos produtores brasileiros. Por meio da equalização, o governo cobre a diferença entre a taxa de juros praticada no mercado financeiro e a taxa efetivamente paga pelo produtor. Para ilustrar, cite o seguinte exemplo: o governo define que o empréstimo para custeio da safra terá juros de $5 \%$ ao ano. Se para a mesma operação o mercado financeiro cobrar uma taxa de $20 \%$, a diferença (15 pontos percentuais) será paga pelo Tesouro Nacional, que emitirá títulos públicos em favor dos bancos financiadores. Desse modo, os juros da agricultura ficam menores do que os praticados no mercado.

A equalização também pode ser feita em outros tipos de operação financeira e setores econômicos. Nas exportações, v.g., a política de equalização é usada para que as empresas brasileiras paguem as mesmas taxas cobradas no mercado internacional, permitindo que o produto nacional concorra em condições iguais às dos congêneres estrangeiros (Disponível em: <http://www2.camara.leg.br/camaranoticias/noticias/76087.html>. Acesso: 2 jul. 2014).

${ }^{421}$ Lei $n^{o}$ 12.999/2014: autoriza o pagamento de subvenção econômica aos produtores da safra 2012/2013 de cana de açúcar da Região Nordeste; Lei $n^{\circ}$ 12.865/2013: autoriza, dentre outras medidas, o pagamento de subvenção econômica aos produtores da safra 2011/2012 de cana de açúcar e de etanol que especifica e o financiamento da renovação e implantação de canaviais com equalização da taxa de juros; Lei $n^{\circ}$ 12.877/2013: abre crédito extraordinário, em favor de encargos financeiros da União, no valor de R\$ 380 milhões, para viabilizar o pagamento de subvenção econômica às unidades industriais produtoras de etanol combustível da Região Nordeste; Decreto $n^{o}$ 7.077/2010: regulamenta a Lei $n^{\circ}$ 9.445, de 14 de março de 1997, que concede subvenção econômica ao preço do óleo diesel consumido por embarcações pesqueiras
} 
concedidas ao referido setor também possibilita verificar que as políticas de auxílio financeiro estão basicamente divididas em dois grupos, de acordo com a própria Organização para a Cooperação e Desenvolvimento Econômico (OCDE). O primeiro grupo, inerente aos atos de comercialização, é considerado política de suporte baseada na produção de commodities; o segundo, adstrito ao crédito rural, em que a política de suporte se baseia no uso de insumos, tem como principal instrumento a equalização das taxas de juros, no âmbito tanto do Programa Nacional de Agricultura Familiar (Pronaf) quanto da agricultura industrial $^{422}$.

Esses programas atingiram significativa relevância não apenas por sua essencialidade, mas, também, por conta do impacto que geram nos fatores macroeconômicos, como inflação e taxas de juros, não restando dúvidas que a provisão e os preços dos alimentos, quando fora de controle, podem gerar conflitos socioeconômicos, crises e impactos devastadores na economia

O jornalista inglês Peter Popham ${ }^{423}$ corrobora a situação apontada, ao atribuir aos episódios de volatilidade dos preços das commodities à causa de tantas revoluções, citando como exemplo as crises no Oriente Médio e África.

Infere-se, assim, que a redução ou supressão de qualquer política subvencionista, ainda que a princípio seja precária e revogável e, portanto, possa ser alterada de acordo com sua eficácia e os propósitos da Administração Pública ${ }^{424}$, pode trazer efeitos indesejáveis, uma vez que determinados setores da atividade econômica se valem desses recursos financeiros para estruturar seus processos produtivos e de distribuição que, ao longo do tempo, tornam-se insubstituíveis ${ }^{425}$.

A delimitação das subvenções ao longo do tempo e a mensuração de sua eficácia, a qual está atrelada aos propósitos que ensejaram sua concessão, constituem um dos

nacionais; Decreto $n^{-}$6.252/2007: dispõe sobre a concessão de subvenção econômica nas operações de empréstimo e financiamento destinadas às empresas dos setores de pedras ornamentais, beneficiamento de madeira, beneficiamento de couro, calçados e artefatos de couro, têxtil, de confecção, inclusive linha lar, e de móveis de madeira etc. (Disponível em: <www.legislacao.planalto.gov.br〉. Acesso: 2 out. 2014).

${ }^{422}$ Vejam-se programas instituídos pelo Ministério do Desenvolvimento Agrário (MDA), disponíveis em: <http://www.mda.gov.br>. Acesso em: 2 jul. 2014.

${ }^{423}$ POPHAM, Peter. The price of food is at the heart of this wave of revolutions. The Independent, Londres, 27 fev. 2011. Disponível em: <http://www.independent.co.uk/news/word/africa/the-price-of-food-is-at-theheart-of-this-wave-of-revolutions-2226896.html>. Acesso em: 23 jun. 2014.

${ }^{424}$ JÈZE, Gaston. Principios generales del derecho administrativo, p. 54.

${ }^{425}$ ECHEVARRÍA, Santiago García. Política de subvenciones: (la inspección financiera en el sector mixto de la economía). Paper n. 15. Universidad de Alcal/Instituto de Direción y Organización de Empresas (IDOE), 1983. p. 10. Disponível em: <http://dspace.uah.es/dspace/handle/10017/3074>. Acesso em: 5 jun. 2014. 
principais desafios para a Administração Pública, incumbida de fiscalizar as entidades beneficiadas e a utilização dos recursos públicos. Afinal, "a concessão de subvenção implica empobrecimento do Estado e enriquecimento da entidade que a recebe" ${ }^{426}$.

Ainda que a concessão da subvenção econômica pressuponha alguma contrapartida pelo beneficiário na forma como estabelecida nos instrumentos de ajuste específicos, bem se sabe que estes, na maioria das vezes, deixam de atendê-las ou realizálas, até mesmo por falta de específica previsão legal.

Santiago García Echevarría ${ }^{427}$ sustenta que seria necessário delimitar as subvenções e sua realização ao longo do tempo, suprimindo-as gradativamente de maneira que os riscos envolvidos em todo o processo voltem a ser assumidos totalmente por seus beneficiários e que, por consequência, devolva-se ao orçamento do Estado a flexibilidade necessária para poder, do ponto de vista político, social e econômico, atender a novas necessidades, até mesmo imprevisíveis. $\mathrm{O}$ autor ${ }^{428}$ pondera:

\footnotetext{
Una política de subvenciones no puede acumular las nuevas subvenciones junto con las viejas y que, por lo tanto vaya deteriorando la eficacia de las transferencias públicas, de manera que el Estado no logre los grados necesarios de eficacia para poder realizar las tareas que le imponen.
}

Além da delimitação proposta pelo autor, seria necessário empreender maior fiscalização acerca do cumprimento das contrapartidas impostas em lei, bem como melhor planejar a implementação das políticas de subvenção econômica e, assim, inserir seu destino na peça orçamentária e no ato de liberação, e não mais em medidas provisórias ou mediante criação de despesas extraordinárias.

Afinal, como a história mostra, embora ninguém esteja isento de prestar contas do que recebeu do Poder Público, os diversos episódios de corrupção impõem, além das medidas sugeridas, que se retome a consciência ética neste País com relação ao dinheiro público e ao orçamento $^{429}$.

\footnotetext{
${ }^{426}$ OLIVEIRA, Regis Fernandes de. Curso de direito financeiro, p. 452.

${ }^{427}$ ECHEVARRÍA, Santiago García. Política de subvenciones: (la inspección financiera en el sector mixto de la economía). Paper n. 15. Universidad de Alcal/Instituto de Direción y Organización de Empresas (IDOE), 1983. p. 11. Disponível em: <http://dspace.uah.es/dspace/handle/10017/3074>. Acesso em: 5 jun. 2014.

${ }^{428}$ Ibidem, loc. cit..

429 TORRES, Ricardo Lobo. Tratado de direito constitucional, financeiro e tributário: o orçamento na Constituição, p. 58.
} 


\section{DÍVIDA PÚBLICA, CRÉDITO PÚBLICO, ORÇAMENTO E INTERVENÇÃO NO DOMÍNIO ECONÔMICO}

\subsection{Breve intróito}

Neste capítulo, diante da larga utilização da contração da dívida pública, buscar-seá demonstrar sua relevância como instrumento de intervenção no domínio econômico, pois, como adverte Fernando Pérez Royo, "a dívida pública representa a segunda mais importante dentre as formas de receita à disposição do Estado" ${ }^{430}$.

O presente trabalho propõe-se, assim, a abordar os conceitos de crédito público, empréstimo público, endividamento e dívida pública, sua natureza jurídica, características, classificações e, por fim, apontar a relevância e influência que a dívida pública exerce sobre o domínio econômico.

Rogério de Menezes Corigliano ${ }^{431}$ anota que o uso e o emprego do empréstimo público antecedem a era cristã. $\mathrm{O}$ autor indica alguns registros históricos, os quais fariam menção a negócios que assim o caracterizariam e, ao mesmo tempo, também ressalva ser impossível precisar um fato histórico que indique quando os governantes e os Estados passaram a se valer desse instituto.

Nessa mesma linha, Aliomar Baleeiro ${ }^{432}$ relata que apenas alguns textos se limitam a prestar esclarecimentos acerca da finalidade dos empréstimos, dos juros cobrados à época e as circunstâncias que cercavam a celebração, cobrança e extinção dos contratos. Dentre eles, cita os empréstimos tomados por Atenas para aquisição de barcos de guerra, cujos fatos são relatados por Xenofonte; o empréstimo contraído por Cartago para pagar indenizações decorrentes da batalha de Zama; e, ainda, a correspondência trocada entre Cícero com Ático, a qual tem por objeto os empréstimos concedidos por banqueiros.

\footnotetext{
${ }^{430}$ ROYO, Fernando Pérez. Derecho financiero y tributario: parte general, p. 547: "la deuda pública representa la segunda en importancia entre las formas de ingreso a disposición del Estado".

${ }^{431}$ CORIGLIANO, Rogério de Menezes. Empréstimos públicos. 2003. Dissertação (Mestrado) - Faculdade de Direito da Universidade de São Paulo, São Paulo, 2003, f. 26.

${ }^{432}$ BALEEIRO, Aliomar. Uma introdução à ciência das finanças, p. 432-433.
} 
A grande diferença que se nota entre o modelo empregado naquela época e o atual é o fato de os empréstimos estarem atrelados à pessoa do governante, do rei ou imperador, pois eram tomados com o propósito de atender a suas necessidades e vontades pessoais e não com o de satisfazer os interesses públicos.

Com isso, prevaleciam a insegurança e a cobrança de juros muito altos, pois, na maioria das vezes, aqueles que sucediam o reino ou o império se negavam a honrar a dívida contraída por seu antecessor alegando, justamente, o fato de essas dívidas terem sido contraídas pessoalmente, e não pelo reino.

Na Idade Média, e ainda que a contração fosse mais frequente, nenhuma alteração significativa é apontada pela doutrina.

Os empréstimos públicos continuavam a se revestir do caráter de obrigação pessoal do governante e, na maioria das vezes, destinavam-se ao financiamento das guerras, que induziam os credores ou prestamistas a exigir “juros onerosíssimos e garantias humilhantes, que iam desde o fio da barba sacratíssima de Sua Majestade, príncipes tomados como reféns, relíquias de santos, até o penhor da coroa, joias ou a vinculação de certas rendas ao serviço de juros e amortizações da dívida" ${ }^{433}$.

Já na Idade Moderna, para se ter ideia do significado e importância que os empréstimos públicos e a palavra crédito tomaram, basta visitar as obras de William Shakespeare, cujas noções marcaram uma época e ainda hoje fazem parte dos pensamentos econômicos, pois estão intimamente atreladas ao que se entende, ou se compreende, por produção, troca, distribuição e consumo de riqueza ${ }^{434}$.

Escritas durante o Período Elisabetano ou Período Isabelino, compreendido pelos anos de 1558 até 1603, então reconhecido como a "era dourada da história inglesa", o teatro assumiu a posição de difundidor de conhecimento em massa, tendo em vista a inexistência de outros meios de comunicação e a escassez de obras escritas, geralmente reservadas àqueles com melhores condições financeiras, poder ou aos quais por estes eram limitadas.

\footnotetext{
${ }^{433}$ BALEEIRO, Aliomar. Uma introdução à ciência das finanças, p. 434.

${ }^{434}$ FRANCO, Gustavo H. B.; FARNAM, Henry W. Shakespeare e a economia. Rio de Janeiro: Zahar, 2009. p. 126.
} 
O teatro, na Inglaterra, e diante das peças de Shakespeare, tomou proporções jamais vistas durante o referido período, sendo possível constatar nas obras desse autor fatos que demonstram profundas transformações na economia, então decorrentes da expansão do império e da exploração do mercado exterior.

Como prefere Henry Farnam, o teatro era "uma usina criadora de palavras e sobretudo de combinações entre elas de enorme valor, tal como nos mercados, onde circulavam as moedas, multiplicando as trocas e as riquezas" ${ }^{, 435}$.

$\mathrm{Na}$ época, Shakespeare retratava os fatos vivenciados por si, pela sociedade e, principalmente, as atitudes tomadas pela rainha, a ponto de mencionar em suas peças a implantação de uma política monetária restritiva e tratar do saneamento do meio circulante como instrumentos de reorganização do sistema monetário, implantados por Elisabeth I. Relata, ainda, a existência de pelo menos trinta e seis diferentes moedas nacionais e estrangeiras que circulavam sem restrição alguma, tanto quanto o convívio com a inflação, as trapaças monetárias, os pacotes econômicos e até mesmo a criação do token fiduciário, o qual era produzido com metais de baixo valor e se destinava à circulação, como moeda de troca $^{436}$.

Reconhecido como a época em que se firmava a noção de "boa moeda", o período histórico em questão foi marcado pelo

[...] extraordinário crecimento das relações crédito/débito interpessoal, acarretando novas formas de subjetividade que o teatro viria a capturar. Formas novas de negociabilidade e compensação de dívidas das quais resultou uma importantíssima inovação financeira, a inland bill of exchange, que permitiu o crescimento da economia "sem uma expansão proporcional na cunhagem de moedas" (coinage, no original $)^{437}$.

Dentre as inúmeras passagens textuais retratadas por Shakespeare, identifica-se sem dificuldade - v.g., em $O$ mercador de Veneza (1596-1598) ${ }^{438}$, Medida por medida (1603-

\footnotetext{
${ }^{435}$ FRANCO, Gustavo H. B.; FARNAM, Henry W. Shakespeare e a economia, p. 28.

${ }^{436}$ Ibidem, p. 29-34.

437 Ibidem, p. 34

438 Antítese de Tímon de Atenas, Shakespeare, em $O$ mercador de Veneza, toma como tema central o sacrifício em prol da amizade. Antônio, amigo de Bassânio, assume uma obrigação financeira que quase lhe custa a vida, para ajudá-lo a levar adiante uma corte amorosa. Além da amizade, a peça aborda o antagonismo resultante do choque entre as concepções medieval e moderna de juros, fazendo menção à proibição constante do Velho Testamento, de que um judeu cobrasse juros de outro judeu e o fato de que o ouro não produz ouro, além da usura e uma discussão sobre versão extremada do laissez-faire.
} 
$1604)^{439}$ e Tímon de Atenas (1605) $)^{440}$ - o emprego do termo crédito como instrumento destinado a facilitar o comércio e

[...] suas implicações no domínio das finanças públicas e da expansão do crédito, o qual incorporava conceitos modernos no tocante à propriedade, sua transferibilidade, bem como o reconhecimento e negociabilidade de dívidas e créditos, sobretudo através das letras de câmbio, e quanto a cobrança de juros ${ }^{441}$.

Nota-se, com isso, que o vocábulo crédito, já àquela época, era intimamente atrelado ao termo confiança ou crença $a^{442}$, ainda hoje utilizado.

É possível, também, notar nas peças teatrais mencionadas a evolução do que se deve compreender por crédito, débito, fidúcia, dívida e empréstimo, tanto quanto as transformações que esses institutos sofreram ao longo do tempo e as consequências geradas no desenvolvimento de um complexo sistema bancário e de crédito, em que as letras de câmbio e hipoteca eram comumente utilizadas ${ }^{443}$, a ponto de se tornaram determinantes para o aperfeiçoamento do que hoje se compreende por dívida pública.

Percebe-se que, ao longo do tempo, cada vez mais os Estados soberanos se valem dos empréstimos públicos como instrumento financeiro para obtenção de recursos destinados à realização de despesas públicas, e não mais apenas para realização das despesas extraordinárias, como antes se pregava.

As novas funções assumidas pelo Estado, destacadas no primeiro capítulo da presente dissertação, demonstram a necessidade de se encontrar outras fontes de recursos. Tendo como marco inicial o surgimento do que se denomina Estado Fiscal ${ }^{444}$, no qual, com

\footnotetext{
${ }^{439}$ Nesta trama, a questão central gira em torno de uma questão de controle social, a execução da lei em seu sentido literal, desconsiderando os padrões sociais de seu tempo ou a necessidade de ser conivente com males que não se pode erradicar. O duque, responsável pelo cumprimento da lei, assume um disfarce para ver as coisas de um ponto de vista imparcial e as encontra podres, o que o induz a entregar o governo de seu Estado a um delegado que, "vestido com fortuita autoridade", trata de executar a lei literalmente, até se descobrir violando-a.

${ }^{440}$ A obra é marcada pelo retrato de um homem rico e generoso; tão generoso que chega a falir para ser gentil com os amigos que, posteriormente, diante de seu empobrecimento, viram-lhe as costas e se negam a lhe emprestar dinheiro. Sua indignação com a ingratidão daqueles que outrora havia ajudado torna-o amargurado, causando-lhe transtornos mentais.

${ }^{441}$ FRANCO, Gustavo H. B.; FARNAM, Henry W. Shakespeare e a economia, p. 51.

${ }^{442}$ ORÍA, Salvador. Finanzas. Buenos Aíres: Guillermo Kraft, 1948. v. 3, p. 07.

${ }^{443}$ Ibidem, p. 249.

${ }^{444}$ Para Massonetto, "O Estado Fiscal constitui, desta forma, um mecanismo de estabilização das finanças públicas, assentado na formação de uma fazenda pública, distinta do patrimônio do príncipe, e na racionalização da burocracia fiscal, responsável pela arrecadação da receita pública." (MASSONETTO, Luís Fernando. $O$ direito financeiro no capitalismo contemporâneo: a emergência de um novo padrão normativo, p. 20).
} 
o fim do feudalismo e com a separação entre o ius eminens e o poder tributário, entre a fazenda pública e a fazenda do princípe, e entre a política e a economia, é que se desenvolve uma mudança de perfil da receita pública, a qual passa, além dos tributos, a contar com os empréstimos autorizados e garantidos pelo Legislativo ${ }^{445}$.

Superados determinados estigmas dos séculos XVII e XVIII, criados por intelectuais e filósofos como Montesquieu, Jean-Baptiste Colbert, Saint-Simon, François Quesnay, David Hume e Adam Smith, os quais repudiavam o uso de empréstimos públicos, asseverando que estes seriam causadores da ruína das nações ${ }^{446}$, somente a partir de 1930, por influência das ideias de John Maynard Keynes, nota-se maior aceitação de seu uso $^{447}$. Esse novo entendimento ganhou força após a Segunda Guerra Mundial.

Opera-se a partir daí, e de acordo com Giovanni Ingrosso ${ }^{448}$, o desvirtuamento de sua concepção originária de que se estaria diante de um instrumento extraordinário de obtenção de recursos financeiros.

Com o agigantamento do Estado, decorrente de sua evolução de "Estado Polícia" para "Estado Providência", os recursos disponíveis tornaram-se insuficientes à consecução dos fins sociais e ao atendimento das necessidades públicas, socorrendo-se os governantes dos empréstimos públicos como alternativa para satisfazê-las e, com isso, cumprir seu papel social, ao ponto de considerá-los um instituto financeiro permanente ${ }^{449}$.

A utilização dos empréstimos públicos deixa de estar vinculada à ocorrência de situações extraordinárias, provenientes de eventos imprevisíveis e urgentes, como, v.g., calamidades públicas, guerra e comoção, os quais não poderiam ser suportados apenas com as entradas previstas anualmente no orçamento, destinadas à realização de despesas ordinárias $^{450}$, para tornar-se "outro" meio de obtenção de recursos (rotineiro), decorrente

\footnotetext{
445 TORRES, Ricardo Lobo. Curso de direito financeiro e tributário, p. 8.

${ }^{446}$ BALEEIRO, Aliomar. Uma introdução à ciência das finanças, p. 435.

${ }^{447}$ TORRES, Ricardo Lobo. Op. cit., p. 217.

${ }^{448}$ INGROSSO, Giovanni. Corso di finanza pubblica. Napoli: Dott Eugenio Jovene, 1969. p. 541-542. Nas palavras do autor: "Si è altresi accenato anche, parlando dei concetti generali in tema di dinamica del fenomeno finanziario e di entrate intese come strumenti dell'attivita finanziaria, alla caratteristica che si riscontra nella attuale attivitá finanziaria, risidente nell'utilizzo che quest'ultima fa del prestito pubblico non più soltanto come strumento straordinario d'acquisizione di mezzi finanziari, bensi come forma d'entrata ordinaria."

449 Ibidem, p. 543; FONROUGE, Carlos M. Giuliani. Derecho financiero, p. 208; VILLEGAS, Héctor Belisario. Curso de finanzas, derecho financiero y tributario. 4. ed. Buenos Aires: Depalma, 1990. t. I, p. 64. ${ }^{450}$ Ibidem, p. 542.
} 
de uma decisão político-econômica, de que se valem os governantes, como poderá ser observado adiante.

\subsection{Conceito e elementos constitutivos do crédito: confiança, capital e tempo}

Com o intuito de pôr um divisor de águas, afirmou-se, neste estudo, que, antes, os governantes se valiam das terras, da emissão de moedas, da arrecadação de impostos, da extorsão sobre outros povos ou de doações voluntárias para manter seu aparato e atender às necessidades públicas e que, atualmente, recorrem não só à receita proveniente da arrecadação de tributos, mas, também, a outros mecanismos para obter recursos suficientes para satisfazer as despesas públicas, seja para realizar investimentos, seja para arcar com o déficit fiscal, verificado quando as despesas superam o produto da arrecadação ${ }^{451}$.

Em outras palavras, além da arrecadação tributária e dos ingressos patrimoniais, vistos anteriormente, os Estados valem-se de outras rendas, ditas tradicionalmente extraordinárias, para obter recursos capazes de suportar suas obrigações.

Dentre essas rendas mais utilizadas, encontra-se a contração de dívidas, a qual constitui a faculdade de tomar dinheiro por empréstimo da mesma forma de que se valem os particulares para financiar a casa própria, a compra de um veículo e até mesmo os estudos, uma viagem etc..

Em suma, quando o Estado recorre ao crédito que goza no mercado, fazendo-se devedor, cria a dívida pública. Daí o nome de batismo dado ao tema por diversos autores que também o tratam sob a denominação de crédito público ou débito público, indiferentemente e de acordo com a perspectiva de cada observador ${ }^{452}$.

Giovanni Ingrosso ${ }^{453}$ diz que "per debito pubblico devesi intendere l'insieme dei debiti contrati dallo Stato e dagli altri enti pubblici", consistindo o empréstimo

${ }^{451}$ MATIAS-PEREIRA, José. Finanças públicas: a política orçamentária no Brasil. 3. ed. São Paulo: Atlas, 2006. p. 143.

${ }^{452}$ ATALIB A, Geraldo. Empréstimos públicos e seu regime jurídico. São Paulo: RT, 1973. p. 13.

${ }^{453}$ INGROSSO, Giovanni. Corso di finanza pubblica, p. 557. 
público, “una vera e propria cessione di capitale monetario, a fronte della qualle lo Stato o l'Ente pubblico assume l'obbligo della resttituzione del capitale stesso, alla scadenza prevista, e della corresponsione degli interessi”.

Da definição apresentada, nota-se que a dívida pública é composta pelo capital financeiro, ou recursos, tomados pelo Estado ou seus organismos autônomos perante terceiros ${ }^{454}$, cuja expressão, de acordo com Fernando Sainz de Bujanda ${ }^{455}$, pode ser definida como se segue:

Con la expresión "crédito público" se alude a la possibilidad por parte de un ente público de aprovecharse de la confianza de que puede gozar por parte de otros sujetos de derecho (público o privado) para lograr los medios con que subvenir a sus necessidades.

Demonstra-se, com isso, que a confiança ainda hoje constitui o principal elemento do crédito, tanto que sua concepção é extraída do próprio termo crédito, o qual se mantém o mesmo desde o início da era cristã. Percebe-se, dos escritos de Shakespeare, a íntima relação do crédito com a ideia de confiança ou fé na conduta de uma pessoa, relacionada a "duas formas de crença: a confiança ou fé na moral de uma pessoa disposta a cumprir com seus deveres e obrigações, e a crença de que poderá cumpri-los, por dispor de meios econômicos" $" 456$.

Nessa toada, é importante esclarecer que a dívida pública "abrange apenas os empréstimos captados no mercado financeiro interno ou externo, através de contratos assinados com os bancos e instituições financeiras ou do oferecimento de títulos públicos em geral" ${ }^{457}$.

Excluem-se, portanto, a emissão de papel moeda e as operações que se caracterizam como dívida da Administração, como, v.g., aluguéis, aquisição de bens, prestação de serviços e condenações judiciais.

Conforme ensinamento de Horacio Guillermo Corti ${ }^{458}$, a operação de crédito público, como mecanismo de obtenção de recursos, dá lugar, de modo imediato, ao nascimento de uma dívida e origem a um gasto público. Ao contrair a dívida pública,

\footnotetext{
${ }^{454}$ ROYO, Fernando Pérez. Derecho financiero y tributario: parte general, p. 548.

455 BUJANDA, Fernando Sainz de. Lecciones de derecho financiero. 7. ed. Madrid: Universidad Complutense; Facultad de Derecho, Sección de Publicaciones, 1989. p. 400.

${ }^{456}$ ORÍA, Salvador. Finanzas, p. 07.

${ }^{457}$ TORRES, Ricardo Lobo. Curso de direito financeiro e tributário, p. 219.

${ }^{458}$ CORTI, Horacio Guillermo. Derecho constitucional presupuestario, p. 619.
} 
compromete-se a renda futura para atender às atuais necessidades financeiras do Estado.

Veja-se:

[...] las operaciones de crédito público son todas las técnicas jurídicas mediante las cuales el Estado obtiene recursos financieros obligándose, de forma correlativa, a devolver en cierto plazo la suma obtenida, más un interés. La propia operación de crédito público hace nacer una deuda, de forma que los aspectos recaudatorios y erogatorios no son posibles de escindir ${ }^{459}$.

Geraldo Ataliba ${ }^{460}$ sustenta que, ainda que o Estado possa ser devedor por diversas formas, para se configurar empréstimo público

[...] é preciso que o nascimento da obrigação que o tem no polo negativo - como sujeito passivo, devedor - tenha sido determinada pela livre manifestação de vontade do credor. Só assim se preenche o requisito da contratualidade da relação, conferindo-lhe a qualidade de empréstimo.

Logo, o crédito, ou sua concessão, como já salientado, mostra-se intimamente ligado à ideia de confiança, à fidúcia, ou à fé de que determinada pessoa cumprirá seus deveres e obrigações, tanto quanto terá disponibilidade econômico-financeira para arcar com o pagamento da dívida contraída ao longo do tempo. A propósito, Sérgio Assoni Filho ${ }^{461}$ assinala:

[...] o crédito implica a troca de um bem ou valor no presente por uma promessa de riqueza futura que, aliás, será a responsável pelo reembolso do que foi emprestado e pelo pagamento dos juros ou outros benefícios oferecidos aos prestamistas.

Em outras palavras, como relata Geraldo Ataliba ${ }^{462}$, “o empréstimo em dinheiro, como instituto jurídico, leva em consideração, objetiva e subjetivamente, a confiança que pode merecer uma determinada pessoa, para o cumprimento de uma determinada obrigação".

${ }^{459}$ CORTI, Horacio Guillermo. Derecho constitucional presupuestario, p. 619.

${ }^{460}$ ATALIB A, Geraldo. Empréstimos públicos e seu regime jurídico, p. 26.

${ }^{461}$ ASSONI FILHO, Sérgio. Crédito público e responsabilidade fiscal. Porto Alegre: Nuria Fabris, 2007. p. 18.

${ }_{462}^{4}$ ATALIBA, Geraldo. Op. cit., p. 15. 
É possível afirmar, portanto, que os elementos constitutivos do crédito são a confiança, a existência de capital e o fator tempo, pois, como já salientado por Geraldo Ataliba $^{463}$, "as relações jurídicas de direito público e privado, que se reúnam sob a designação genérica de empréstimo, são revestidas das mesmas qualidades essenciais".

E, diante dos elementos constitutivos do crédito, os quais "aplicam-se ao crédito de forma genérica, abrangendo tanto a idéia de crédito público quanto a de crédito privado", há que se reconhecer a dificuldade em distingui-los, pois entre eles "é bastante sensível e centrada essencialmente na natureza do tomador do empréstimo, bem como na finalidade por ele encampada no momento em que recorre à operação de crédito" ${ }^{464}$.

Há, assim, que se reconhecer que o crédito público e, por conseguinte, todas as operações, tais como aquelas verificadas nas transações privadas, devem pautar-se por valores de lealdade, coerência e colaboração, fundando-se o contrato na credibilidade e confiança.

\subsection{Os empréstimos públicos e as receitas ordinárias}

No Capítulo 3, o presente estudo valeu-se da definição de Regis Fernandes de Oliveira, para afirmar que receita pública "é a entrada definitiva de dinheiro e bens nos cofres públicos ${ }^{, 465}$.

Além disso, no tocante às receitas públicas, relatou-se que estas se classificam de acordo com (i) a periodicidade e (ii) a origem.

No caso da periodicidade, as receitas se subdividem em extraordinárias, quando ocorre o ingresso excepcional de recursos, destinados a atender a situações imprevistas e indesejáveis (art. 154, II, da CF/1988); e ordinárias, quando havidas com regularidade, decorrente do desenvolvimento regular da atividade estatal (v.g., com a cobrança de impostos).

\footnotetext{
${ }^{463}$ ATALIB A, Geraldo. Empréstimos públicos e seu regime jurídico, p. 10.

${ }^{464}$ Ibidem, p. 19.

${ }^{465}$ OLIVEIRA, Regis Fernandes de. Curso de direito financeiro, p. 128.
} 
No que toca à origem, elas se subdividem em originárias, derivadas e transferidas, isto é, de modo sintético, trata-se, respectivamente, daquelas decorrentes da exploração pelo Estado de seus próprios bens, do constrangimento sobre o patrimônio do particular ou, então, daquelas que, embora provenientes do patrimônio do particular, não são arrecadadas pela entidade política que vai utilizá-las ${ }^{466}$.

Na situação específica dos empréstimos públicos, o presente estudo também afirma que, embora seja tido como entrada de recursos, pois todo e qualquer dinheiro que ingressa nos cofres públicos assim deve ser considerado, estes não constituem receita. A posição ora externada se coaduna com o entendimento de Regis Fernandes de Oliveira ${ }^{467}$, segundo o qual, todo recurso financeiro que ingressa nos cofres públicos, ainda que provisoriamente, constitui receita, mesmo que depois seja devolvido ao credor ou prestamista.

Remanesceria, apenas, e não fosse o reconhecimento pacífico pelos doutrinadores, dentre os quais cita-se Giovanni Ingrosso ${ }^{468}$, dúvidas atinentes a sua periodicidade, ou seja, se ainda seria possível afirmar que os empréstimos públicos constituem receita extraordinária.

A resposta e algumas considerações acerca dessa indagação se mostram relevantes em face dos propósitos do presente estudo.

Ao reconhecer os empréstimos públicos como receitas extraordinárias, estaria afastada a possibilidade de serem os recursos obtidos utilizados para a realização de despesas ordinárias? Ainda, por serem destinados à realização de despesas extraordinárias, estaria o contraente impossibilitado de efetuar gastos em infraestrutura ou conceder estímulos à economia com os recursos financeiros obtidos?

Diante das indagações colocadas, mostram-se pertinentes as considerações de Fernando Sainz de Bujanda ${ }^{469}$, quando sustenta que o caráter extraordinário da dívida não

\footnotetext{
${ }^{466}$ OLIVEIRA, Regis Fernandes de. Curso de direito financeiro, p. 129-130.

${ }^{467}$ Ibidem, p. 126-127.

${ }^{468}$ INGROSSO, Giovanni. Corso di finanza pubblica, p. 546-547.

${ }^{469}$ BUJANDA, Fernando Sainz de. Lecciones de derecho financiero, p. 404. Nas palavras do autor: "Sin embargo, el carácter extraordinario que tradicionalmente se ha atribuido a la Deuda, basándose en las razones anteriormente apuntadas, no ha perdido todo su valor en la actualidad. Con él se alude muchas veces a que, entre los motivos que puedan inducir al Estado a contraer deuda, puede encontrarse la necesidad de hacer frente a gastos extraordinarios y la impossibilidad de forzar más los ingresos tributarios. Sin perjuicio de aceptar la relatividad de esta categoría de gastos extraordinarios, es desde este punto de vista desde el que se
} 
perdeu totalmente seus valores, podendo encontrar dentre os motivos que podem induzir o Estado a contrair dívida, a necessidade de fazer frente a gastos extraordinários e a impossibilidade de aumentar a carga tributária. Tudo sem prejuízo de se aceitar a relatividade da categoria de gastos extraordinários.

Ricardo Lobo Torres ${ }^{470}$, ao tratar do tema, embora não considere o empréstimo público um tipo de receita pública, é claro ao afirmar que os empréstimos perderam o caráter de medida extraordinária e passaram a ingressar no orçamento fiscal, juntamente com a previsão para o pagamento dos juros e das amortizações.

Nesse aspecto, vale trazer a definição de dívida pública divulgada pela Secretaria do Tesouro Nacional do País: “dívida pública - dívida contraída pelo governo com o objetivo de financiar gastos não cobertos com a arrecadação de impostos" ${ }^{\text {471 }}$.

Na atualidade, a dívida pública constitui um meio normal de o Estado obter recursos e, como já assinalado, um instituto permanente, afastando as circunstâncias extraordinárias que antigamente justificavam sua contração, o que induziu vários autores a afirmarem que os recursos financeiros provenientes de empréstimos públicos passaram a deter a natureza de ingressos ordinários.

Como pondera Héctor Villegas Belisario" ${ }^{472}$, "la teoría moderna se orienta hacia la idea de que el empréstito es un recurso que nada tiene de anormal, y que no puede estar rígidamente limitado a circunstancias excepcionáis".

Essa orientação se deve não apenas à necessidade do Estado, de se socorrer de outros meios de obtenção de recursos para atender a seus propósitos, os quais se alargaram sobremaneira, mas, também, em face da habitualidade com que passaram a contrair dívidas, deixando o empréstimo de ser mero ingresso excepcional e esporádico.

puede criticar una política de ingresos fáciles que recurra al crédito para hacer frente a los gastos ordinarios del Estado".

${ }^{470}$ TORRES, Ricardo Lobo. Curso de direito financeiro e tributário, p. 218.

471 Disponível em: <http://www.tesouro.fazenda.gov.br/glossario-do-tesouro-direto>. Acesso em: 17 out. 2014.

${ }^{472}$ VILLEGAS, Héctor Belisario. Curso de finanzas, derecho financiero y tributario, 9. ed., p. 64. 


\title{
5.4 Natureza jurídica
}

Estabelecido que a receita proveniente da contração de dívida é considerada um instituto permanente do fenômeno financeiro e apresentadas suas principais definições e elementos constitutivos de forma genérica, faz-se necessário distinguir o crédito público do privado, o que somente se mostra possível mediante a análise e compreensão da natureza jurídica do empréstimo público.

Por cautela, adverte-se que a modalidade de empréstimo público a ser analisada, e que dá origem à dívida pública, é originária do mútuo, tal qual estabelece o Código Civil, nos arts. $586^{473}$ e $591^{474}$, dentre outros.

São esclarecedoras as palavras de José Maurício Conti ${ }^{475}$, ao distinguir o mútuo da figura jurídica do financiamento:

\begin{abstract}
Empréstimo é o gênero do qual são espécies o mútuo e comodato. A menção a empréstimos ora feita é referente à espécie mútuo. Mútuo é um tipo de contrato que cria a obrigação ao mutuário de restituir ao mutuante o que dele recebeu, tendo como características principais o fato de ter como objeto coisas fungíveis, ser temporário e real, e permite a estipulação de juros (Código Civil, arts. $1.256 \mathrm{e}$ ss.). Financiamento é um tipo de negócio jurídico que normalmente se dá entre instituição financeira, que adianta recursos, a alguém que deles necessite para algum empreendimento. Em geral vincula-se a outro negócio jurídico, como a importação de bens.
\end{abstract}

Vale lembrar que, para alguns autores, o empréstimo público submete-se aos mesmos princípios que norteiam o empréstimo privado, dentre os quais se apresenta a livre manifestação de vontade em contraposição à compulsoriedade, cuja característica é inerente aos tributos. Os tributos, por sua vez, constituem outra fonte de receita pública ao lado dos empréstimos públicos, distinguindo-se no que toca à obrigatoriedade de devolver o valor arrecadado.

\footnotetext{
${ }^{473}$ Conforme redação do Art. 586, "O mútuo é o empréstimo de coisas fungíveis. O mutuário é obrigado a restituir ao mutuante o que dele recebeu em coisa do mesmo gênero, qualidade e quantidade.".

${ }^{474} \mathrm{O}$ art. 591 reza o seguinte, "Destinando-se o mútuo a fins econômicos, presumem-se devidos juros, os quais, sob pena de redução, não poderão exceder a taxa a que se refere o art. 406, permitida a capitalização anual.".

${ }^{475}$ CONTI, José Maurício. Direito financeiro na Constituição de 1988. São Paulo: Oliveira Mendes, 1998. p. $70-71$.
} 
De todo modo, e como destaca com precisão Fernando Sainz de Bujanda ${ }^{476}$, a utilização do crédito não é o único meio de endividamento do Estado, o que pode se dar mediante uma série de outros mecanismos, devendo, por isso, cada um deles ser analisado de acordo com cada caso e dentro dos limites de cada figura jurídica.

É o que se constata da leitura do inc. III, do art. 29, da LRF, em que operação de crédito é definida como sendo o compromisso financeiro assumido em razão de mútuo, abertura de crédito, emissão e aceite de título, aquisição financiada de bens, emissão e aceite de título, aquisição financiada de bens, recebimento antecipado de valores provenientes da venda a termo de bens e serviços, arrendamento mercantil e outras operações assemelhadas, inclusive com o uso de derivativos financeiros.

Nesse aspecto, como ressalta Regis Fernandes de Oliveira ${ }^{477}$, torna-se necessário esclarecer que antes mesmo do advento da Lei de Responsabilidade Fiscal, para a doutrina, as operações de crédito não se referiam apenas aos contratos de empréstimo.

É, no entanto, diante de todas essas observações e pormenores que surgem posições antagônicas acerca da natureza jurídica dos empréstimos públicos, as quais estão longe de alcançar qualquer consenso.

Para Giuliani Fonrouge, v.g., "el empréstito público tiene el carácter de una obligación unilateral de derecho público, derivada de la soberanía, y en su forma clásica de operaciones a largo plazo y a plazo intermedio ha originado la idea errónea de que se trata de un contrato" 478 .

Fernando Sainz de Bujanda ${ }^{479}$, por sua vez, sustenta que os empréstimos públicos detêm natureza jurídica contratual regida pelo direito público e que, portanto, estar-se-ia diante de um contrato administrativo; afinal, "cuando la Administración contrata Deuda pública defiende un interés colectivo primario, posibilitando el desarrollo de los servicios públicos de actividad total del Estado" 480 .

\footnotetext{
${ }^{476}$ BUJANDA, Fernando Sainz de. Lecciones de derecho financeiro, p. 401.

${ }^{477}$ OLIVEIRA, Regis Fernandes de. Responsabilidade fiscal. 2. ed. São Paulo: RT, 2002. p. 73.

${ }^{478}$ FONROUGE, Carlos M. Giuliani. Derecho financiero, p. 208.

${ }^{479}$ BUJANDA, Fernando Sainz de. Op. cit., p. 404-407.

${ }^{480}$ Ibidem, p. 407.
} 
Essa concepção dá origem a uma terceira teoria, a qual também confere aos empréstimos públicos caráter tipicamente contratual, porém, defende a posição de que esses seriam regidos pelo direito privado.

Assim, diante das diversas teorias envolvendo a natureza jurídica do empréstimo público, a presente dissertação limitar-se-á à análise das três apontadas há pouco por considerá-las as mais relevantes. Para essa análise, divide-as, como a própria doutrina sugere, entre aqueles que afirmam tratar-se de uma (i) obrigação unilateral autônoma de direito público e aqueles que dizem tratar-se de (ii) contrato, os quais, por sua vez, se subdividem entre os defensores segundo os quais este é regido pelo (ii.a) direito privado e os defensores da ideia de este ser regido pelo (ii.b) direito público.

Saliente-se que, em razão de essas teorias já terem sido examinadas à exaustão por Regis Fernandes de Oliveira ${ }^{481}$ e Sérgio Assoni Filho ${ }^{482}$, tomar-se-á, nesta dissertação, a liberdade de expor apenas os pontos e as questões mais relevantes.

Dentre os adeptos da primeira corrente destacam-se Carlos M. Giuliani Fonrouge, Saygués Laso, Luis María Drago, Giovanni Ingrosso, Sá Filho, os quais propugnam a concepção de que os empréstimos públicos constituem uma obrigação unilateral autônoma de direito público em que as condições fixadas se traduziriam em um ato de soberania do Estado. Esse ato, por sua vez, daria origem a uma obrigação unilateral de direito público.

Os adeptos dessa teoria também propugnam que, por se tratar de um ato de soberania, seria inadmitida a execução forçada da dívida pelo credor, a qual ganhou relevo quando uma esquadra mista, formada pela Inglaterra, Alemanha e Itália, bombardeou São Carlos, em decorrência da bancarrota da Venezuela.

Esse fato deu origem à chamada "doutrina de Drago", a qual fora exposta em nota datada de 29 de dezembro de 1902, subscrita pelo então Ministro do Exterior da Argentina, Luis María Drago, e entregue ao Departamento de Estado em Washington ${ }^{483}$.

\footnotetext{
${ }^{481}$ OLIVEIRA, Regis Fernandes de. Curso de direito financeiro, p. 660-665.

${ }^{482}$ ASSONI FILHO, Sérgio. Crédito público e responsabilidade fiscal, p. 29-48.

${ }^{483}$ BALEEIRO, Aliomar. Uma introdução à ciência das finanças, p. 473.
} 
Em referida nota, Luis María Drago repudia a cobrança militar dos empréstimos e assinala que de maneira alguma defende a má-fé, a desordem e a insolvência deliberada e voluntária, devendo ser assegurada a liberdade das nações ${ }^{484}$, isto é, sua soberania.

Para Regis Fernandes de Oliveira ${ }^{485}$, a teoria em foco - da obrigação unilateral autônoma de direito público - não se sustenta porque são necessários dois atos jurídicos autônomos para que a contração do empréstimo público se opere efetivamente - (i) o ato de autorização legislativa e (ii) o ato de concretização do empréstimo. O primeiro ato somente produz efeitos com a promulgação da lei pertinente, momento em que se opera a alteração da ordem normativa, o que, portanto, constitui ato de soberania do Estado. O segundo ato, por sua vez, consistente na efetiva contratação e, portanto, decorre da livre manifestação daqueles que pretendem contratar com o Estado, seja adquirindo seus títulos, seja emprestando-lhe algum dinheiro.

Assim, por se tratar de ato bilateral, produto da livre manifestação de vontade do contratante, não mais se estaria diante de um ato de soberania que, no entendimento do presente estudo e já adiantando, não retira o caráter contratual dos empréstimos públicos, nem tampouco impede a propositura da competente demanda judicial, tendente a compelir o Poder Público a cumprir o contratado.

A propósito, Regis Fernandes de Oliveira ${ }^{486}$ assenta:

[...] o que não se admite é a agressão internacional para exigência do débito. $O$ constrangimento militar é inviável, no concerto atual dos países, disciplinada a ordem internacional por obediência a pactos e tratados, embasados e firmados nas noções da não intervenção e da soberania dos Estados.

Exemplo dessa situação é o que se verificou recentemente com a Argentina, ao recusar satisfazer o crédito de um pequeno grupo de investidores, rotulados de "fundos abutres" e cujo investimento correspondia a US\$ 1,5 bilhão da dívida do país.

\footnotetext{
${ }^{484}$ Nas palavras do autor: "No es ésto de ninguna manera defender la mala fe, el desorden y la insolvencia deliberada y voluntaria. Es simplemente amparar el decoro de la entidad pública internacional que no puede ser arrastrada así á la guerra, con perjuicio de los altos fines que determinan la existencia y libertad de las naciones" (DRAGO, Luis María. Cobro coercitivo de deudas públicas. Buenos Aires: Coni Hermanos, 1906. p. 14).

${ }^{485}$ OLIVEIRA, Regis Fernandes de. Curso de direito financeiro, p. 661-662.

${ }^{486}$ Ibidem, p. 662.
} 
Diante do inadimplemento, o grupo de credores propôs, perante a Justiça de Nova York, nos Estados Unidos da América, a competente ação judicial, na qual restou decidido pelo pagamento integral em favor dos demandantes e, mais ainda, foi mantida a ordem judicial que proíbe a Argentina de pagar qualquer outro credor enquanto não liquidar o crédito exequendo.

Além disso, a decisão proferida pelo Judiciário norte-americano poderá dar início a uma série de cobranças de pagamentos adicionais, calculados entre US\$ 15 e 20 bilhões, o que certamente contribuirá para agravar a crise econômica e financeira enfrentada no país, cujos reflexos são sentidos em toda a América Latina ${ }^{487}$.

Como demonstrado pelo exemplo citado, a posição defendida por aqueles que comungam da ideia de se tratar de uma obrigação unilateral autônoma de direito público já não se sustenta por completo.

Para Regis Fernandes de Oliveira ${ }^{488}$, a soberania do Estado impede que este sofra agressão internacional e, ainda que se verifique a impenhorabilidade dos bens públicos, esta não impede o ajuizamento da competente ação judicial, nem tampouco posterior satisfação do débito exequendo, o qual, no Brasil, dar-se-ia de acordo com o rito previsto no art. 100 da CF/1988, com a inclusão do precatório no orçamento.

Nesse sentido já se pronunciou Amílcar de Araújo Falcão ${ }^{489}$ e bem esclareceu que:

“[...] um dos pontos de partida da tese anti-contratualista tem em vista o empréstimo externo. Algumas vezes, Estados credores tentaram constranger militarmente Estados devedores inadimplentes a solverem os seus débitos decorrentes de empréstimos externos.

A condenação de tal procedimento, que encontrou na doutrina de Drago o seu ponto culminante, tinha como um dos seus fundamentos a assertiva de ser o empréstimo público um ato de soberania e, portanto, não comportar a sua prática ou as decorrências que dela provenham execução forçada ou coativa, tanto no plano interno, como no âmbito externo".

487 Disponível em: <http:/g1.globo.com/jornal-da-globo/noticia/2014/07/argentina-da-calote-na-dividaexterna-pela-segunda-vez-em-treze-anos.html>. Acesso em: 27 out. 2014.

${ }^{488}$ OLIVEIRA, Regis Fernandes de. Curso de direito financeiro, p. 662.

${ }^{489}$ FALCÃO, Amílcar de Araújo. Natureza dos empréstimos públicos. Revista de Direito Público, ano IV, v 13, jul.-set. 1973, p. 12. 
Não se admite, portanto, a agressão armada em que se verificaria "um atentado contra a soberania do Estado a que se dirige, qualquer que seja a natureza do ato, contratual, legislativo, jurisdicional, ato político, ou outro, que tenha sido tomado como motivo da agressão" 490 .

Os defensores da segunda corrente, por sua vez, dão ao contrato característica tipicamente contratual, remanescendo, como já advertido, a discussão acerca de seu regime jurídico, se é regido pelo direito privado ou pelo direito público.

Estudiosos como Gabriel Franco, Henri Laufenburger, Alberto Deodato e Paul Laband estão entre os que afirmam tratar-se de contrato regido pelo direito privado e, em razão disso, defendem a teoria de que os empréstimos públicos devem seguir a disciplina jurídica do mútuo traçado no sistema jurídico nacional, ou seja, pelo Código Civil, e, portanto, seriam regidos pelo direito privado.

Gaston Jèze, Guido Zanobini, Marcel Waline, Louis Trotabas, André de Laubadère, Fernando Sainz de Bujanda, Themístocles Brandão Cavalcanti, José Cretella Júnior e Geraldo Ataliba, dentre outros, apregoam a teoria de que os empréstimos públicos são contratos de direito administrativo, de natureza semelhante à das demais relações contratuais estabelecidas pelo Estado e, assim, regidos pelo direito público.

Nesse passo, mostra-se pertinente trazer à colação os ensinamentos de Fernando Sainz de Bujanda ${ }^{491}$, conforme a seguir:

Pues bien, creemos que se puede afirmar que la actividad que desarrolla la Administración cuando contrata un empréstito la realiza como tal Administración, dotada de poder de imperio y sin colocarse en un plano de igualdad con el particular y que, por tanto, el contrato a que da lugar es un contrato administrativo.

En efecto, cuando la Administración contrata Deuda pública defiende un interés colectivo primario, posibilitando el desarrollo de los servicios públicos de la actividad total del Estado.

En segundo lugar, la presencia de las llamadas "cláusulas exorbitantes", los privilegios que se conceden a los prestamistas, la prescripción especial, la jurisdicción que entiende de los litigios que en torno a estos contratos se promueven, la intención de las partes, etc., ponen de relieve que es un ente público como tal quien contrata, y que la relación a la que se da vida encuentra su régimen jurídico normal en las normas de Derecho Administrativo.

\footnotetext{
${ }^{490}$ FALCÃO, Amílcar de Araújo. Natureza dos empréstimos públicos. Revista de Direito Público, ano IV, v 13, p. 13.

${ }^{491}$ BUJANDA, Fernando Sainz de. Lecciones de derecho financeiro, p. 407.
} 
Adepto dessa teoria, segundo a qual os empréstimos públicos constituem contratos de direito público, Regis Fernandes de Oliveira ${ }^{492}$ assim defende: "ele[s] difere[m] do comum não só pela finalidade - ou seja, sempre está presente um interesse público -, mas também pela exigência de forma especial, no caso a lei, e também pela unilateralidade da rescisão e da alteração das denominadas cláusulas regulamentares". O estudioso ${ }^{493}$ ainda esclarece:

\begin{abstract}
Trata-se de contrato de direito público porque: a) deve haver previsão orçamentária; b) exige disposição legal específica do órgão legislativo solicitante; c) há obrigatoriedade de autorização e controle do Senado; d) necessária a finalidade pública; e) é possível alteração unilateral de determinadas cláusulas, se assim foi previsto na lei; f) há sujeição a prestação de contas; g) há inviabilidade de execução específica; e h) pode ocorrer possibilidade de rescisão unilateral (resgate antecipado).
\end{abstract}

Nessa mesma linha, cujo pensamento também se coaduna com o endossado pela presente dissertação, Sérgio Assoni Filho ${ }^{494}$ afirma:

[...] o empréstimo público é um contrato de direito público (contrato administrativo em sentido estrito), pois é um contrato ofertado pelo ente público tomador, com base em seu crédito, tendo em vista uma finalidade pública, unilateralmente fixando as condições de restituição futura do capital, e que é aceito pelo prestamista, pessoa física ou jurídica, pública ou privada, que dispõe do capital solicitado pelo primeiro.

Consideradas essas posições, vale acrescentar a anotação feita por Geraldo Ataliba $^{495}$, na qual sustenta que o empréstimo público pressupõe a liberdade de contratar, sendo irrelevante que o credor, emprestador, mutuante ou prestamista seja pessoa pública ou privada ou, até mesmo, pessoa de direito internacional.

Reconhecida a natureza contratual do empréstimo público e que este é regido pelo direito público, mostra-se pertinente apresentar o conceito de contrato administrativo proposto por Bandeira de Mello. Para o autor ${ }^{496}$, trata-se de

\footnotetext{
${ }^{492}$ OLIVEIRA, Regis Fernandes de. Curso de direito financeiro, p. 664.

${ }^{493}$ Ibidem, p. 664.

${ }^{494}$ ASSONI FILHO, Sérgio. Crédito público e responsabilidade fiscal, p. 48.

${ }^{495}$ ATALIB A, Geraldo. Empréstimos públicos e seu regime jurídico, p. 6.

${ }^{496}$ MELLO, Celso Antônio Bandeira de. Curso de direito administrativo, p. 626-627.
} 
[...] um tipo de avença travada entre a Administração e terceiros na qual, por força da lei, de cláusulas pactuadas ou do tipo de objeto, a permanência do vínculo e as condições preestabelecidas assujeitam-se a cambiáveis imposições de interesse público, ressalvados os interesses patrimoniais do contratante privado.

Deve-se ressaltar que, ainda que o Estado ou a Administração estabeleça unilateralmente as condições da contratação, isso não lhe retira o caráter contratual, pois o prestamista detém a faculdade de se submeter, ou não, às condições propostas. Existe, portanto, não uma imposição decorrente do poder de império do Estado, mas sim um acordo de vontades ${ }^{497}$

Deveras, e como já manifestado, este estudo considera que o regime jurídico dos contratos de empréstimo público é o de direito público, o que se deve pela presença do Estado no polo passivo da relação obrigacional e, consequentemente, o envolvimento do interesse público, o qual deve prevalecer sobre o interesse do particular, bem como pela existência de cláusulas especiais que acabam por privilegiar o ente público.

Em síntese, "genericamente, empréstimo público é o contrato administrativo pelo qual o Estado recebe determinado valor que se obriga a pagar, na forma por ele estipulada" ${ }^{\prime 498}$.

Além de se tratar de contrato administrativo e, com isso, regido pelo direito administrativo, é pertinente ressaltar que deve sempre estar presente o interesse público, ou seja, o interesse do todo, de um conjunto.

\subsection{Classificações}

Reconhecido o atual caráter ordinário da receita gerada com o ingresso de recursos financeiros oriundos de empréstimos contraídos pelo ente público, o presente estudo passa a se ocupar do esforço doutrinário dedicado a propor uma classificação da dívida pública,

\footnotetext{
${ }^{497}$ ASSONI FILHO, Sérgio. Crédito público e responsabilidade fiscal, p. 44.

${ }^{498}$ OLIVEIRA, Regis Fernandes de. Curso de direito financeiro, p. 660.
} 
ainda que, no direito, as classificações existentes não sejam certas nem erradas, mas úteis e inúteis para os propósitos a que se destinam ${ }^{499}$.

O importante, como adverte Regis Fernandes de Oliveira, é que se tenha "em mira o critério de discriminação" para apartar "o material objeto de estudo" 500 .

Considerado o propósito traçado logo no início da presente dissertação, o qual se resume em demonstrar que o orçamento público constitui um importante instrumento de intervenção no domínio econômico, a dívida pública assume papel fundamental e relevante.

O ente público, ao optar por contraí-la, ao mesmo tempo abdica do seu poder de império de instituir tributos e arrecadá-los, deixando de onerar a sociedade e a iniciativa privada, bem como onera as gerações futuras, mas, também, fomenta determinadas atividades com alocação de recursos, investimentos em obras de infraestrutura, concessão de empréstimos ou incentivos fiscais etc..

Neste cenário, e dentre as várias alternativas presentes no mercado econômico dos prestamistas, adotar-se-á, neste trabalho, a classificação sugerida pelo texto constitucional brasileiro, dividindo-as (i) em relação à pessoa jurídica que contraia a dívida (federal, estadual ou municipal); (ii) em relação ao local de pagamento do crédito (internas e externas); e, por fim, (iii) quanto ao seu prazo de duração (dívida consolidada ou fundada e flutuante).

Além das alternativas apontadas pelo texto constitucional, e diante de sua relevância, também será objeto de análise a dívida mobiliária, tendo em vista o tratamento específico recebido pela Lei de Responsabilidade Fiscal.

${ }^{499}$ CARRIÓ, Genaro A. Notas sobre derecho y lenguaje, p. 99.

${ }^{500}$ OLIVEIRA, Regis Fernandes de. Curso de direito financeiro, p. 672. 


\subsubsection{Dívida federal, estadual e municipal}

Um dos critérios de classificação de classificação da dívida pública propostos consiste em separá-la - a dívida pública - em federal, estadual ou municipal, ou seja, de acordo com o ente da federação que a contrai, o polo subjetivo do contrato ${ }^{501}$. Assim, classifica-se a dívida pública de acordo com a pessoa jurídica de direito público tomadora do empréstimo aos prestamistas ${ }^{502}$, dívida essa que será denominada de acordo com o ente que a contraia - se a União, dívida federal, se um Estado, dívida estadual; se um Município, dívida municipal.

É o que sugere o art. 52, incs. VI e VII, da CF/1988, ao relacionar dentre as competências privativas do Senado Federal, a prerrogativa de fixar, por proposta do Presidente da República, limites globais para o montante da dívida consolidada da União, dos Estados, do Distrito Federal e dos Municípios, bem como dispor sobre os limites globais e condições para as operações de crédito externo e interno dos respectivos entes federativos, suas autarquias e demais entidades controladas pelo Poder Público federal.

No que tange à importância dessa classificação, é pertinente transcrever a observação feita por Sérgio Assoni Filho ${ }^{503}$ sobre o assunto:

Ressalte-se que essa classificação traz à baila a importante questão da competência legislativa, uma vez que, embora os empréstimos públicos a serem contratados por todos os entes federativos devam ter seus limites e condições fixados pelo Senado Federal, apenas os seus respectivos Poderes Legislativos, dentro de suas respectivas esferas, poderão autorizar mediante lei a contratação dos empréstimos.

Cabe, assim, ao Poder Legislativo competente, ou seja, ao Poder Legislativo da respectiva esfera governamental tomadora do empréstimo, autorizar ou não a contratação da dívida, ainda que o Senado Federal detenha competência privativa para dispor sobre os limites globais do crédito interno e externo dos entes federativos (art. 52, VII, da CF/1988).

\footnotetext{
${ }^{501}$ OLIVEIRA, Regis Fernandes de. Curso de direito financeiro, p. 672.

${ }^{502}$ ASSONI FILHO, Sérgio. Crédito público e responsabilidade fiscal, p. 54.

${ }^{503}$ Ibidem, p. 54.
} 


\subsubsection{Dívida pública externa e interna}

A dívida pública interna e a externa têm causas e consequências distintas, embora possam ter implicações uma sobre a outra.

De forma indireta, o texto constitucional brasileiro, no art. 52, inc. V, também faz referência à presente classificação, ao estabelecer que compete ao Senado Federal, privativamente, autorizar operações externas de natureza financeira, e, no inc. VII do mesmo dispositivo, atribuir-lhe a competência para estabelecer os limites globais e as condições para as operações de crédito externo e interno dos entes da Federação.

O mesmo entendimento se extrai do disposto no art. 163, inc. II, da CF/1988, o qual estabelece que cabe à lei complementar dispor sobre dívida pública externa e interna, incluída a dívida das autarquias, fundações e demais entidades controladas pelo Poder Público.

Essa classificação, como pondera Sérgio Assoni Filho ${ }^{504}$, não contém na doutrina um conceito preciso do que se deve entender por dívida pública interna e externa, havendo uma infinidade de critérios adotados pelos financistas, dentre os quais, citem-se (i) o mercado ou celebração do contrato; (ii) o local de pagamento ou de execução do contrato; (iii) a nacionalidade da moeda adotada; (iv) a nacionalidade dos contratantes; e (v) o ordenamento jurídico aplicável ao contrato.

Nota-se que Regis Fernandes de Oliveira ${ }^{505}$, ao traçar uma distinção, o faz com relação ao local de pagamento do crédito, esclarecendo que:

\footnotetext{
A interna é emitida e resgatada dentro do mercado de um país, independentemente de serem os mutuários brasileiros ou estrangeiros. A externa não tem caracterização pela moeda de pagamento, mas pela transferência de divisas ao exterior, e, pois, o que importa é o local ou a praça em que o pagamento deva ser feito.
}

\footnotetext{
${ }^{504}$ ASSONI FILHO, Sérgio. Crédito público e responsabilidade fiscal, p. 56.

${ }^{505}$ OLIVEIRA, Regis Fernandes de. Curso de direito financeiro, p. 672.
} 
Geraldo Ataliba ${ }^{506}$ e Ricardo Lobo Torres ${ }^{507}$, por sua vez, preferem distingui-las de acordo com a nacionalidade dos contratantes, assinalando, este último, que a "dívida pública interna é a contraída diretamente com as instituições financeiras no País ou através da colocação de títulos do Governo no mercado anônimo de capitais" ${ }^{\text {"508 }}$, enquanto a dívida externa é a

[...] contraída com Estados Estrangeiros, com instituições financeiras mantidas pela ONU e por outros organismos internacionais (Fundo Monetário Internacional, Banco Internacional para o Desenvolvimento Econômico BIRD), com bancos estrangeiros ou através de títulos colocados nos mercados internacionais de capitais ${ }^{509}$.

O Senado Federal brasileiro, de acordo com o art. $3^{\circ}$ da Resolução $n^{0}$ 43/2001, adota esse critério ao definir operação de crédito conforme a seguir:

[...] compromissos assumidos com credores situados no País ou no exterior, em razão de mútuo, abertura de crédito, emissão e aceite de título, aquisição financiada de bens, recebimento antecipado de valores provenientes da venda a termo de bens e serviços, arrendamento mercantil e outras operações assemelhadas, inclusive com o uso de derivativos financeiros.

Já Fernando Sainz de Bujanda" ${ }^{510}$ assinala que "la Deuda pública podrá estar denominada en pesetas o en moneda extranjera y emitirse tanto en el interior como en el exterior" e, com isso, adota a nacionalidade da moeda para diferenciar a dívida pública externa da interna.

Como se vê, a norma e a doutrina adotam critérios diversos para distinguir a dívida pública entre interna e externa e, ainda que referidas classificações se mostrem irrelevantes à primeira vista, deve-se considerá-las não apenas como um simples critério de classificação, mas, também, com base nas consequências advindas da contração de uma ou de outra, no que toca aos efeitos que podem ser gerados.

\footnotetext{
${ }^{506}$ ATALIBA, Geraldo. Empréstimos públicos e seu regime jurídico, p. 75.

${ }^{507}$ TORRES, Ricardo Lobo. Curso de direito financeiro e tributário, p. 220-221.

${ }^{508}$ Ibidem, p. 220-221.

${ }^{509}$ Ibidem, p. 221.

${ }^{510}$ BUJANDA, Fernando Sainz de. Lecciones de derecho financiero, p. 408.
} 
A propósito, mostram-se pertinentes e oportunas as considerações de Alejandro Ramirez Cardona ${ }^{511}$, cujo critério de diferenciação adotado é o do local de negociação, ou, como prefere o autor, o círculo econômico de onde provém o capital.

Para Alejandro Cardona, o Estado, ao contrair a dívida no mercado interno, não produz o desejado aumento da renda nacional, pois o dinheiro circula apenas nas mãos do prestamista e da entidade tomadora, e sua utilização dar-se-á apenas para regular a economia em períodos de inflação. Já a dívida contraída no exterior implicaria evidente mudança de "círculo econômico", ou seja, ingresso de recursos monetários provenientes de uma economia distinta, pois este não pertence ao ente público mutuário e os recursos são, geralmente, empregados na realização de investimentos e em infraestrutura, proporcionando a distribuição de renda.

Com isso, verifica-se que a adoção de políticas deve ser devidamente planejada, levando em conta as distinções apontadas, a fim de que se possam evitar ou minimizar resultados indesejáveis. Devem-se, ainda, estabelecer margens para as reações provocadas no mercado interno.

\subsubsection{Dívida flutuante e dívida fundada ou consolidada}

O critério utilizado para distinguir a dívida pública flutuante da fundada ou consolidada, a despeito das severas críticas tecidas por Geraldo Ataliba ${ }^{512}$, ainda continua sendo o do prazo de duração, ou seja, o prazo durante o qual há de ser pago e extinto o contrato de empréstimo público ${ }^{513}$.

\footnotetext{
${ }^{511}$ CARDONA, Alejandro Ramirez. Sistema de hacienda pública, p. 419-420: "El empréstito interno. El empréstito interno sustrae capital del mismo circuito económico a que pertenece el ente público prestatario. La modalidad interna de empréstito se utiliza para la cobertura de los más variados gastos, desde los de funcionamiento hasta los de inversión y trasferencia. [...]. El empréstito interno no aumenta la renta nacional: parte de ella pasa de unas manos a otras, de los particulares al ente público, que la devuelve luego en intereses y amortización. [...]. El empréstito externo. El empréstito externo toma dinero prestado de otro circuito económico distinto al que pertenece el ente público prestatario. Esta modalidad de empréstito se destina generalmente a gastos de inversión productiva e infraestructurales." (grifo do original).

${ }_{512}$ ATALIB A, Geraldo. Empréstimos públicos e seu regime jurídico, p. 81-87.

${ }^{513}$ BALEEIRO, Aliomar. Uma introdução à ciência das finanças, p. 484.
} 
Na lição de Aliomar Baleeiro, "a dívida flutuante se caracteriza pelos vencimentos em termos brevíssimos, como meses ou um ano no máximo" e "é contraída para suprir os embaraços de tesouraria: a) para cobrir o déficit; b) porque as receitas só ingressam no Tesouro em época posterior à necessidade de realização de despesas prementes ou com vencimento em data fixada na lei" ${ }^{, 514}$.

A aparição constitucional dessa modalidade de dívida se dá, ainda que de maneira sutil, no art. 165, $\S 8^{\circ}$, cuja referência é feita nas entrelinhas ao estabelecer as exceções ao princípio orçamentário da exclusividade; consta, expressamente, da Lei Federal $\mathrm{n}^{\mathrm{o}}$ 4.320/1964, no art. 92, segundo o qual compreende a dívida flutuante: (i) os restos a pagar; (ii) os serviços da dívida a pagar; (iii) os depósitos; e (iv) os débitos de tesouraria ${ }^{515}$.

Além disso, a LRF, no art. 38, conceitua a dívida flutuante quando faz menção às operações de crédito por antecipação de receitas orçamentárias, assinalando que estas se destinam a atender à insuficiência de caixa durante o exercício financeiro, e desde que atendidas, também, as exigências constantes do art. 32 .

No que tange ao prazo de resgate, este é deduzido do disposto no art. 28 da Lei Federal n⿳⺈ 4.320/1964 e no $\S 3^{\circ}$, do art. 29, da LRF, os quais estabelecem, respectivamente, que "a dívida fundada compreende os compromissos de exigibilidade superior a 12 (doze) meses"; e que "também integram a dívida pública consolidada as operações de crédito de prazo inferior a 12 (doze) meses".

Tem-se, assim, que a dívida pública consolidada ou fundada é o "montante total, apurado sem duplicidade, das obrigações financeiras do ente da Federação, assumidas em virtude de leis, contratos, convênios ou tratados e de realização de crédito, para amortização em prazo superior a 12 (doze) meses" (art. 29, I, da LRF).

As distinções em referência, legais, coadunam-se com o conceito proposto por Regis Fernandes de Oliveira ${ }^{516}$, o qual une o critério da finalidade ao do prazo de duração, ao esclarecer que dívida flutuante é aquela adquirida para suprir deficiência de caixa e deve ser resgatada no curto prazo, constituindo, assim, uma situação provisória, enquanto a dívida consolidada ou fundada tem prazo longo e se destina à realização de investimentos.

\footnotetext{
${ }^{514}$ BALEEIRO, Aliomar. Uma introdução à ciência das finanças, p. 484.

${ }^{515}$ ASSONI FILHO, Sérgio. Crédito público e responsabilidade fiscal, p. 58-59.

${ }^{516}$ OLIVEIRA, Regis Fernandes de. Curso de direito financeiro, p. 673.
} 
Giovanni Ingrosso ${ }^{517}$ adota essa mesma concepção, para salientar que a dívida flutuante é qualificada quase pela totalidade da doutrina como empréstimos temporários, provisórios ou transitórios, pois estes são contratados por um período não superior a um ano e detêm a função de suprir a momentânea exigência de caixa do tesouro.

Além disso, conforme anota Geraldo Ataliba ${ }^{518}$, "a operação de crédito por antecipação de receita é um tipo de empréstimo que o poder público faz com a exclusiva finalidade de suprir eventuais quedas de arrecadação", as quais se equiparam à dívida flutuante, pois detém as seguintes características: "o curto prazo; o volume reduzido e sempre proporcional, não só às necessidades de pagamento dentro do curto prazo; e a sua aplicação em despesas corriqueiras da própria administração”.

A propósito, Regis Fernandes de Oliveira ${ }^{519}$ informa que o texto constitucional brasileiro traz um único exemplo, no $\S 8^{0}$ do art. 165. O autor destaca, ainda, que a Constituição Federal de 1988 não reproduziu o disposto na anterior, a qual atribuía limites a esse tipo de operação, estabelecendo limites e prazos.

Regis Fernandes de Oliveira também observa que as operações aludidas estão disciplinadas no art. $14^{520}$ da Resolução $n^{0}$ 43/2001 do Senado Federal, e que elas independem de autorização deste ${ }^{521}$.

É importante observar, que, conforme dispõe o texto constitucional, a suspensão do pagamento da dívida flutuante por mais de dois anos consecutivos, salvo motivo de força maior, constitui causa de intervenção federal (art. 34, V, a). No mesmo sentido, a inadimplência da dívida fundada por dois anos consecutivos sem motivo de força maior dá ensejo à intervenção estadual (art. 35, I).

\footnotetext{
${ }^{517}$ INGROSSO, Giovanni. Corso di finanza pubblica, p. 560.

${ }^{518}$ ATALIB A, Geraldo. Empréstimos públicos e seu regime jurídico, p. 105-106.

${ }^{519}$ OLIVEIRA, Regis Fernandes de. Empréstimos públicos no Brasil. In: MELLO, Celso Antônio Bandeira de (Org.). Estudos em homenagem a Geraldo Ataliba: direito tributário. São Paulo: Malheiros, 1997. v. I, p. 245 .

${ }_{520}^{\text {p. }}$ Conforme teor do art. 14, “A operação de crédito por antecipação de receita orçamentária deve cumprir as seguintes condições:

I - realizar-se somente a partir do décimo dia do início do exercício;

II - ser liquidada, com juros e outros encargos incidentes, até o dia 10 (dez) de dezembro de cada ano;

III - não será autorizada se forem cobrados outros encargos que não a taxa de juros da operação, obrigatoriamente prefixada ou indexada à taxa básica financeira, ou à que vier a esta substituir;

IV - será vedada enquanto existir operação anterior da mesma natureza não integralmente resgatada.".

${ }^{521}$ OLIVEIRA, Regis Fernandes de. Curso de direito financeiro, p. 696.
} 
No mais, e diante das distinções propostas, é de relevância fazer menção às considerações de Émerson César da Silva Gomes, ao alertar para as mudanças introduzidas pela LRF, as quais teriam implicado a alteração do critério de distinção entre dívida flutuante e dívida fundada, não mais subsistindo o critério do prazo de exigibilidade, mas, sim, o da autorização legislativa. Veja-se:

\begin{abstract}
Assim, com o advento da LRF, melhor dizer que a dívida flutuante é aquela classificada no passivo financeiro (art.105, § $3^{3}$, da Lei 4.320/1964), ou seja, é aquela cujo pagamento independe de autorização orçamentária.
\end{abstract}

A dívida fundada, por sua vez, é aquela classificada no passivo permanente (art. $105 \S 4^{\circ}$, da Lei 4.320/1964), cujo pagamento depende de autorização legislativa para amortização ou resgate ${ }^{522}$.

No entanto, em face das menções anteriores e levando-se em conta o quanto expresso nos dispositivos constitucionais citados, ainda hoje é possível concluir que a Lei Maior brasileira adotou o critério temporal como sendo determinante para distinguir a dívida flutuante da fundada, ainda que guarde certa consonância com o critério da autorização legislativa.

\title{
5.5.4 Dívida mobiliária
}

Prevista na Constituição Federal brasileira (art. 52, IX), a dívida mobiliária é definida pela Secretaria do Tesouro Nacional como sendo a "dívida pública representada por títulos públicos emitidos pelo Tesouro Nacional" ${ }^{\prime 523}$. Saliente-se que é competência privativa do Senado Federal estabelecer os limites e condições da dívida mobiliária dos entes da Federação, à exceção da União.

${ }^{522}$ GOMES, Émerson César da Silva. Das autarquias e outras entidades. In: CONTI, José Maurício. Orçamentos públicos: a lei 4.320/1964 comentada, p. 328.

${ }_{523}$ Disponível em: <http://www3.tesouro.fazenda.gov.br/servicos/glossario/glossario_d.asp>. Acesso em: 17 out. 2014 
Observa-se que a referida Secretaria se vale da definição apresentada no inc. II $^{524}$ do art. 29 da LRF, o que diferencia a dívida mobiliária da dívida consolidada, a qual detém origem nas obrigações financeiras assumidas em face de leis, contratos, convênios ou tratados e da realização de operações de crédito, cuja amortização se dê em prazo superior a doze meses, conforme inc. I do dispositivo em questão.

A dívida mobiliária federal é composta pela soma de tudo aquilo que todos os órgãos do Estado brasileiro devem, incluindo o Governo Federal, os Estados, os Municípios e o próprio Banco Central, devendo seu limite estar previsto em ato do Congresso Nacional (art. 48, XIV, da CF/1988), ao passo que a dívida consolidada da União deve estar prevista em resolução do Senado Federal (art. 52, VI, da CF/1988).

Com o art. 29 da LRF, é possível afirmar que se atribuiu um regime específico para a dívida mobiliária, estabelecendo, além de sua composição, a possibilidade de ser o principal refinanciado, desde que não exceda, ao término de cada exercício financeiro, o montante do final do exercício anterior, somadas as operações de crédito autorizadas no orçamento e efetivamente realizadas, acrescido de atualização monetária (art. 29, § $4^{\circ}$, da LRF).

Ressalte-se que, além disso, o refinanciamento da dívida mobiliária não se sujeita a determinadas vedações, tal qual se verifica com as operações de crédito, em que, não observados determinados limites, impedem o ente de realizar operações de crédito internas e externas, inclusive por antecipação de receita (art. $31, \S 1^{\underline{o}}$, I, da LRF).

Por fim, cumpre anotar que as operações inerentes à dívida mobiliária federal gozam de tratamento especial no que se refere à aprovação e controle pelo Ministério da Fazenda - seu procedimento é simplificado (art. 32, § $2^{\circ}$, da LRF) e a aquisição de títulos da dívida da União é permitida aos Estados e Municípios (art. 35, § 2º , da LRF), ao contrário das demais operações de crédito, cuja realização entre os entes da Federação é vedada, nos termos do caput do art. 35 da LRF.

\footnotetext{
${ }^{524} \mathrm{O}$ referido inciso tem o seguinte teor: "II - dívida pública mobiliária: dívida pública representada por títulos emitidos pela União, inclusive os do Banco Central do Brasil, Estados e Municípios.”.
} 


\subsection{Histórico da dívida pública brasileira e os limites de endividamento}

Diante do quanto até então apresentado sobre dívida pública, pode-se afirmar que suas principais alterações decorrem de mudança de ideologia bastante significativa envolvendo o sistema financeiro, decorrentes do Estado Liberal e da estrutura capitalista.

Essa mudança eleva os impostos ao posto de principal fonte de recursos públicos, e os empréstimos financeiros deixam de ser utilizados pelos Governos como mera receita extraordinária. Os empréstimos assumem, com isso, a função de antecipar a arrecadação tributária e de sustentar os investimentos de longo prazo.

No entanto, no Brasil, como será observado a seguir, a dificuldade em administrar a dívida pública e a ineficiência de se valer desse importante instrumento de antecipação de receita acarretaram vários problemas e prejuízos ainda hoje sentidos.

A exemplo de outros países - como Portugal e Espanha, em que o patrimonialismo impera há décadas -, a história tem demonstrado que a utilização da dívida pública sem planejamento e responsabilidade, somada a outros fatores como a corrupção, eleva o nível de despesas dos Estados com o pagamento de juros mais altos, emperram o desenvolvimento e acarretam danos irreparáveis à sociedade e à economia.

\subsubsection{Breve escorço histórico}

Antes de se separar da metrópole (Portugal), o Brasil "ainda não tinha uma dívida pública no sentido técnico da palavra, embora governadores e veneranças da colônia contraíssem empréstimos desde os séculos XVI e XVII" ${ }^{525}$.

Como esclarece Anderson Caputo Silva ${ }^{526}$, nessa época, os empréstimos públicos

\footnotetext{
${ }^{525}$ BALEEIRO, Aliomar. Uma introdução à ciência das finanças, p. 437.

${ }^{526}$ SILVA, Anderson Caputo. Origem e história da dívida pública no Brasil até 1963. In: SILVA, Anderson Caputo; CARVALHO, Lena Oliveira de; MEDEIROS, Otavio Ladeira de (Orgs.). A dívida pública: a experiência brasileira. Brasília: Secretaria do Tesouro Nacional; Banco Mundial, 2009. p. 33. Disponível em:
} 
se confundiam com os empréstimos pessoais dos governantes e tudo era desconhecido: o tamanho da dívida, a finalidade do empréstimo, as condições em que era realizado etc..

Foi nesse período, todavia, que se verificou o início da dívida pública brasileira. Enquanto tropas de Napoleão Bonaparte invadiam Portugal, a Coroa portuguesa se transferia para cá e consigo trazia a dívida contraída perante a Inglaterra ${ }^{527}$. Os fatos e ações marcantes para a história política, econômica e financeira do Brasil também se deram nessa época, podendo-se destacar (i) a abertura de portos em 1808; (ii) a criação do primeiro Banco do Brasil; e (iii) a implantação do papel-moeda ${ }^{528}$.

Marcado pelas dificuldades financeiras enfrentadas no período que antecedeu à sua independência, o Brasil, nesses primeiros anos, também tinha de enfrentar as demandas naturais. Esses fatos tornaram a história da dívida brasileira rica em vários aspectos: (i) criou-se a primeira agência de administração da dívida pública; (ii) institucionalizou-se a dívida pública interna; (iii) ampliaram-se os mecanismos e instrumentos de financiamento; e (iv) realizaram-se operações de reestruturação de dívida ${ }^{529}$.

Ainda no Brasil Império, mediante comissão instituída por D. Pedro I, expede-se a Lei de 15 de novembro de 1827, responsável por fundar a dívida pública interna e externa e criar o Grande Livro e a Caixa de Amortização ${ }^{530}$, a qual, "considerada por muitos a pedra fundamental do crédito público no Brasil, sofreu poucas alterações até a criação do Banco Central, quase 140 anos depois" ${ }^{531}$.

Já no período da República, a história da dívida pública é marcada por uma fase de dificuldades de financiamento interno e externo e de reestruturações que culminaram com a suspensão de pagamentos do serviço da dívida (funding loan), em 1989, 1914 e 1931, até que, em 1943, o Brasil firmou o denominado "acordo permanente da dívida externa" ${ }^{532}$.

\footnotetext{
<http://www3.tesouro.gov.br/divida_publica/downloads/livro/livro_eletronico_completo.pdf>. Acesso em: 26 ago. 2013.

${ }^{527}$ OLIVEIRA, Regis Fernandes de. Curso de direito financeiro, p. 684.

${ }^{528}$ SILVA, Anderson Caputo. Origem e história da dívida pública no Brasil até 1963. In: SILVA, Anderson Caputo; CARVALHO, Lena Oliveira de; MEDEIROS, Otavio Ladeira de (Orgs.). A dívida pública: a experiência brasileira, p. 35.

${ }^{529}$ Ibidem, p. 36.

${ }^{530}$ OLIVEIRA, Regis Fernandes de. Op. cit., p. 684.

${ }^{531}$ SILVA, Anderson Caputo. Op. cit..

${ }^{532}$ Ibidem, p. 44-54.
} 
A dívida externa servia, à época, "para aparelhar o país de seus serviços essenciais, que não existiam ao tempo da Independência, e também para socorro do Tesouro, que sempre vacilara em lançar mão da tributação eficaz"533.

Ainda que esse acordo tenha implicado a redução do nível de endividamento do Brasil, o País voltou, no início dos anos 1950, a sofrer desequilíbrios em suas contas internas e externas. Seu limite de endividamento dobrou entre 1946 e 1953, alcançando mais de US\$ 1 bilhão. Por conta da política de expansão implementada por Juscelino Kubitschek no programa de metas (1957-1960), em 1961 a dívida pública externa total já alcançava o dobro dos níveis de 1955, e a situação do balanço de pagamentos era desastrosa, o que não se alterou nos períodos que se sucederam, nos governos de Jânio Quadros e João Goulart ${ }^{534}$.

Regis Fernandes de Oliveira ${ }^{535}$, em breve síntese, esclarece que o aumento do endividamento se verifica durante os governos Vargas e Kubitschek, com a construção da rodovia Transamazônica, da ponte Rio-Niterói, de usinas nucleares etc..

A partir de 1964, e já no Governo do Marechal Humberto de Alencar Castello Branco, tem-se um novo marco histórico do ponto de vista político e econômico. Com a determinação de gerar um padrão de desenvolvimento sustentável para o País, foram criados o Banco Central e o Conselho Monetário Nacional, por meio da Lei $\mathrm{n}^{-0} 4.595$, de 31 de dezembro de 1964, e, em 1965, instituiu-se o Plano de Ação Econômica do Governo (Paeg). Esse Plano foi concebido com o propósito de, dentre outros objetivos, reduzir as taxas de inflação, implicando a necessidade de se promover reformas no sistema financeiro nacional, a fim de contemplar o desenvolvimento de um mercado eficiente de títulos públicos e, com isso, propiciar tanto a demanda para o financiamento dos déficits públicos quanto a viabilização das operações de política monetária e realização de investimentos ${ }^{536}$.

Essas ações possibilitaram que, no final da década de 1960 e início dos anos 1970, fossem obtidos resultados positivos: (i) as taxas de crescimento da economia apresentavam níveis elevados; e (ii) a inflação atingia níveis inferiores aos observados na segunda

\footnotetext{
${ }^{533}$ BALEEIRO, Aliomar. Uma introdução à ciência das finanças, p. 440.

${ }^{534}$ Ibidem, p. 54

${ }^{535}$ OLIVEIRA, Regis Fernandes de. Op. cit., p. 685.

${ }^{536}$ PEDRAS, Guilherme Binato Villela. História da dívida pública no Brasil: de 1964 até os dias atuais. In: SILVA, Anderson Caputo; CARVALHO, Lena Oliveira de; MEDEIROS, Otavio Ladeira de (Orgs.). A dívida pública: a experiência brasileira, p. 58-59.
} 
metade da década anterior. O Brasil passou a emitir regularmente títulos prefixados e inaugurou o processo de lançamento desses títulos por meio de oferta pública (leilão).

Em meados da década de 1970, o País começou a sentir os efeitos do primeiro choque do petróleo e, em 1974, duplicaram-se as taxas de inflação, e o crescimento da economia cessou, o que se agravou com a segunda crise do petróleo em 1979, momento em que "a inflação atingiu patamares sem precedentes, alcançando a barreira dos três dígitos, e as taxas de crescimento da economia começaram a enveredar para o terreno negativo" 537 .

No ano de 1982, e já no Governo de João Batista de Oliveira Figueiredo, término do ciclo militar, o Brasil devia US\$ 100 bilhões. Os empréstimos eram obtidos de empresas multinacionais ou dos Estados Unidos, em substituição à Inglaterra ${ }^{538}$. Em 1986, foram adotadas medidas profundas, visando alcançar maior controle fiscal, o que resultou na criação da Secretaria do Tesouro Nacional, mediante o Decreto $\mathrm{n}^{\mathrm{o}}$ 92.452, de 10 de agosto de 1986, com o propósito de centralizar o controle dos gastos públicos ${ }^{539}$.

Os insucessos das políticas levadas a cabo pelo Governo no combate da inflação, todavia, impuseram a adoção de medidas mais enérgicas. A primeira deu-se em 1986, com o Plano Cruzado, em que se verificou (i) o congelamento de preços; (ii) o fim da correção monetária e redução das taxas reais de juros; e (iii) a criação da Letra do Banco Central (LBC), cuja principal característica era ter sua remuneração atrelada à taxa do Sistema Especial de Liquidação e de Custódia (Selic), com indexação diária. Além dessas medidas, o Governo instituiu o Decreto-Lei $\mathrm{n}^{\mathrm{O}}$ 2.376/1987, criando as Letras Financeiras do Tesouro (LFTs), cujas características eram idênticas às da LBC, destinavam-se especificamente ao financiamento dos déficits orçamentários ${ }^{540}$

O insucesso do Plano Cruzado fez que o início de 1987 ficasse marcado por sérias dificuldades na condução da política econômica, que provocaram a total perda do controle do déficit público, agravada em 1988, em face da promulgação da Constituição Federal,

\footnotetext{
${ }^{537}$ PEDRAS, Guilherme Binato Villela. História da dívida pública no Brasil: de 1964 até os dias atuais. In: SILVA, Anderson Caputo; CARVALHO, Lena Oliveira de; MEDEIROS, Otavio Ladeira de (Orgs.). A dívida pública: a experiência brasileira, p. 61.

${ }^{538}$ OLIVEIRA, Regis Fernandes de. Curso de direito financeiro, p. 685.

${ }^{539}$ PEDRAS, Guilherme Binato Villela. Op. cit., p. 62.

${ }^{540}$ Ibidem, p. 63.
} 
bem como da impossibilidade de o Banco Central emitir títulos e, portanto, de financiar o governo $^{541}$.

Em 1990, o estoque de títulos em mercado representavam 15\% do PIB, e a inflação se encontrava em níveis superiores a $1.000 \%$ ao ano ${ }^{542}$. Esse quadro, por si só, demonstra o nível de descontrole da política econômica e financeira.

Dá-se, aí, a segunda medida austera, com a instituição do Plano Collor, cujo objetivo explícito era pôr fim ao processo inflacionário e ao descontrole fiscal vivenciado nos últimos anos. Para tanto, determinou o congelamento de $80 \%$ dos ativos financeiros do País, promoveu a substituição dos indexadores da dívida e, com isso, uma profunda redução na liquidez da economia, até que se verificou uma queda histórica no estoque da dívida em poder do público, de 82,5\%, ainda em 1990. Pouco tempo depois, a dívida e a inflação começaram a se elevar, a ponto de alcançar, em meados da década de 1990, a taxa de $24,8 \%$ ao ano ${ }^{543}$.

Com o fim da era Collor, marcada pelo impeachment do Presidente e início do Governo de Itamar Franco, sobreveio o Plano Real. Instituído em 27 de fevereiro de 1994, pela Medida Provisória n⿳0 434, o Plano contemplou uma série de medidas para debelar a crise: (i) criou a Unidade Real de Valor (URV); (ii) estabeleceu, dentre outras, regras de conversão e uso de valores monetários; (iii) iniciou a desindexação da economia, privatização de estatais, corte de despesas, aumento dos impostos federais em cinco pontos percentuais e, ainda, determinou o lançamento de uma nova moeda, o Real.

O Plano Real, considerado a medida econômica mais ampla já realizada no Brasil, teve como objetivo principal o controle da hiperinflação, que assolava o país. Vários instrumentos econômicos e políticos foram utilizados para promover a redução da inflação, tendo alcançado, em junho de 1994, o patamar de 46,58\% ao mês. Esses mecanismos contribuíram para a queda do nível de endividamento e da inflação, até que, diante da percepção mais otimista dos investidores sobre os rumos da economia, o Brasil retomou seu crescimento e conseguiu estabilizar a moeda.

\footnotetext{
${ }^{541}$ PEDRAS, Guilherme Binato Villela. História da dívida pública no Brasil: de 1964 até os dias atuais. In: SILVA, Anderson Caputo; CARVALHO, Lena Oliveira de; MEDEIROS, Otavio Ladeira de (Orgs.). A dívida pública: a experiência brasileira, p. 64 .

${ }^{542}$ Ibidem, p. 64

${ }^{543}$ Ibidem, p. 65 .
} 
Somam-se a esse conjunto de medidas, a edição da Lei $\mathrm{n}^{0}$ 9.496, de 11 de setembro de 1997, por meio da qual a União estabeleceu critérios para a consolidação, assunção e refinanciamento, dentre outros, da dívida pública mobiliária que era de responsabilidade dos Estados e do Distrito Federal.

Criou-se, também, por intermédio de referida lei, o programa de apoio à reestruturação e ao ajuste fiscal, no qual foram estabelecidas metas e compromissos a serem realizados pelos Estados e pelo Distrito Federal, no tocante (1) à dívida financeira em relação à receita líquida real (RLR); (ii) ao resultado primário, entendido como a diferença entre as receitas e despesas não financeiras; (iii) às despesas com funcionalismo público; (iv) à arrecadação de receitas próprias; (iv) à privatização, permissão ou concessão de serviços públicos, reforma administrativa e patrimonial; e (v) às despesas de investimento em relação à RLR (art. $2^{\underline{0}}$ ).

Em 24 de agosto de 2001, com a edição da Medida Provisória no 2.185-35, concedeu-se autorização à União Federal para assumir as obrigações dos Municípios com instituições financeiras nacionais e estrangeiras, e refinanciá-las dentro dos prazos e critérios de pagamento nela fixados. A Medida também vedou a contratação de novas operações de crédito superiores à razão entre a dívida financeira e a receita líquida real do Município cuja dívida fosse refinanciada pela União.

Por fim, destaca-se a Lei de Responsabilidade Fiscal - Lei Complementar $\mathrm{n}^{\mathrm{o}}$ 101, de 4 de maio de 2000 -, a qual estabelece normas de finanças públicas destinadas a atribuir maior responsabilidade na gestão fiscal, pressupondo a ação planejada e transparente e, com isso, prevenir riscos e corrigir desvios capazes de afetar o equilíbrio econômico das contas públicas, mediante o cumprimento de metas de resultados entre receitas e despesas.

Adotadas essas medidas, as quais contribuíram para maior responsabilidade da gestão pública - e que estão sendo honradas -, verificou-se um aumento da credibilidade do Governo brasileiro e da economia, permitindo a estabilização da moeda e a retomada do crescimento.

No entanto, informações prestadas pela Secretaria do Tesouro Nacional e pelo Ministério da Fazenda em janeiro de 2014 dão conta que, atualmente, o montante da dívida pública federal em 2013 - a qual inclui tudo que o Governo deve aos credores dentro e fora do País - fechou em R \$ 2,12 trilhões, o que corresponde ao aumento de 5,71\% em relação 
ao exercício anterior ${ }^{544}$. Esses dados têm se mostrado preocupantes, haja vista o aumento do nível de endividamento, da inflação e a redução do índice de crescimento da indústria, comércio e economia.

\subsubsection{Requisitos e limites do endividamento público federal}

Como já assinalado, os Estados, assim como as pessoas privadas, recorrem a empréstimos e financiamentos de toda ordem para cumprir seus objetivos e finalidades. Para tanto, tomam recursos de instituições financeiras, empresas e outras pessoas jurídicas de direito pública e, até mesmo, de pessoas físicas, quando lançam títulos ao mercado.

No entanto, no âmbito público a contração de dívidas se dá de maneira um pouco diversa daquela que se verifica no âmbito privado, em que o crédito é concedido de acordo com o grau de confiança (fidúcia) atribuído pela entidade financeira e das garantias ofertadas por aquele que deseja obter o empréstimo.

De início, para contrair a dívida, o Brasil necessita de prévia autorização legislativa; depois, é necessário que haja a representação do ente público, fixando as condições, como, v.g., garantias, prazos de vencimento, formas de resgate etc. ${ }^{545}$.

A Constituição Federal brasileira atribui as obrigações mencionadas ao Senado Federal, responsável, como já esboçado, por autorizar as operações externas de natureza financeira; fixar, mediante proposta do Presidente da República, os limites globais para o montante da dívida consolidada da União e dos demais entes federativos, bem como por dispor sobre os limites globais e condições para ambas as operações de crédito externo e interno (art. 52, V, VI e VII, da CF/1988).

Como se vê, a autorização para contrair dívida limita-se à operação de crédito externa (art. 52, VII, da CF/1988), a qual, embora se esteja tratando apenas da União

\footnotetext{
544 Disponível em: <http://g1.globo.com/economia/noticia/2014/01/divida-publica-sobe-57-em-2013-eatinge-marca-inedita-de-r-212-tri.html>. Acesso em: 18 out. 2014.

545 OLIVEIRA, Regis Fernandes de. Curso de direito financeiro, p. 688.
} 
Federal, alcança todos os entes federativos. Em suma, "nenhum ente público pode realizar qualquer operação externa sem a autorização do Senado" ${ }^{546}$.

As dívidas públicas consolidadas e mobiliárias dos Estados, Municípios e o Distrito Federal, assim como as respectivas administrações diretas, os fundos, as autarquias, as fundações e as empresas estatais dependentes, sujeitam-se às regras da Resolução do Senado Federal n⿳⺈ 40/2001, já mencionada. Essa Resolução veda qualquer operação que implique endividamento, sem o cumprimento de determinações e sem a prévia previsão orçamentária, bem como estipula que, a partir de 2016, as dívidas consolidadas líquidas não poderão ser superiores a $200 \%$ das receitas correntes líquidas, no caso dos Estados, ou a $120 \%$, em se tratando dos Municípios.

Resolução no 40/2001 também estabelece que, até o exercício de 2016, eventuais excessos em relação ao limite fixado deverão ser reduzidos na proporção de, no mínimo, $1 / 15$ ao ano.

Entretanto, a Resolução em comento não traz nenhuma previsão no que tange à União, a qual se submete à Resolução do Senado n⿳0 48/2007, cuja disposição trata, dentre outros, dos limites globais para as operações de crédito externo e interno da União, de suas autarquias e demais entidades controladas pelo poder público federal, bem como estabelece os limites e condições para a concessão de garantia da União em operações de crédito externo e interno, regulamentando, assim, o disposto no inc. V, do art. 52, da CF/1988.

No art. $2^{\underline{0}}$, a Resolução $\mathrm{n}^{\mathrm{o}}$ 40/2001 redefine alguns conceitos e, no inc. III, define dívida consolidada como sendo o

[...] montante total, apurado sem duplicidade, das obrigações financeiras da União, inclusive as decorrentes da emissão de títulos, assumidas em virtude de leis, contratos, convênios ou tratados, da realização de operações de crédito para amortização em prazo superior a 12 (doze) meses, dos precatórios judiciais emitidos a partir de 5 de maio de 2000 e não pagos durante a execução do orçamento em que hajam sido incluídos e das operações de crédito que, embora de prazo inferior a 12 (doze) meses, tenham constado como receitas no orçamento.

\footnotetext{
${ }^{546}$ OLIVEIRA, Regis Fernandes de. Curso de direito financeiro, p. 688.
} 
Ainda, essa Resolução esclarece, no $\S 2^{2}$, que a dívida consolidada não inclui as obrigações existentes entre a Administração direta e as respectivas entidades que integram a União.

Já no art. $7^{\circ}$, dispõe sobre os limites e condições para a realização de operações de crédito, restringindo-as ao montante global de $60 \%$ da receita corrente líquida (inc. I). A respeito do montante da dívida consolidada, determina que esta não poderá exceder o teto estabelecido pelo Senado em resolução específica (inc. II).

De acordo com o art. $8^{\circ}$, os contratos relativos a operações de crédito externo não podem conter nenhuma cláusula de natureza política, atentatória à soberania nacional e à ordem pública ou contrária à Constituição e às leis brasileiras, bem como que implique compensação automática de débitos e créditos.

Preceitua, também, que a União não pode prestar garantia acima de $60 \%$ da receita corrente líquida (art. 9º $)$, as quais somente poderão ser outorgadas, se atendidos os requisitos constantes do art. 10 .

Em síntese, essas são as principais merecedoras de destaque, valendo lembrar que, além das considerações e especificidades apontadas, a Constituição Federal (art. 167, III), veda que se realizem operações de créditos que excedam o montante das despesas de capital, com ressalvas para aquelas autorizadas mediante créditos suplementares ou especiais com finalidade precisa, desde que tenham sido aprovadas pelo Poder Legislativo, por maioria absoluta.

\subsection{A dívida pública e o domínio econômico}

Reitere-se que, como já demonstrado, em geral o Estado, recorre à contratação de empréstimos como meio de obter recursos e os destina não apenas ao pagamento de suas despesas correntes, mas, também, ao atendimento das necessidades públicas. 
Sobre essa questão, Aliomar Baleeiro assinala que "o crédito público inclui-se entre os vários processos de que o Estado pode lançar mão para obtenção de fundos, como método fiscal, ou para outros fins extrafiscais" ${ }^{\prime 547}$.

Não por menos, afirmou-se que os empréstimos públicos perderam sua característica de extraordinariedade e que sua contração tem se dado não apenas como forma de cobrir deficiências de caixa, mas também, muitas vezes, como instrumento destinado a evitar o aumento da carga tributária ${ }^{548}$.

Daí já se verifica a função extrafiscal da dívida pública a que se refere Giovanni Ingrosso, para o qual a dívida pública assume importante papel de incremento e redistribuição de riquezas. Veja-se:

\begin{abstract}
In quest'ultimo, infatti, si ritrovano enunciate, e regolate in buona parte nella loro concreta realizzazione, le finalità extrafiscali del debito pubblico.

Tali finalitá come si è accennato nel precedente paragrafo, si identificano, in sostanza con quelle proprie dell'attività finanziaria contemporanea, compendiandosi esse nella redistribuzione e nell'incremento del reddito nazionale.

E il debito pubblico è un fattore redistributivo di ricchezza, per constituire un mezzo di distrazione di risparmio individuale privato a favore dell'impiego pubblico $^{549}$.
\end{abstract}

Além disso, mostrou-se que a necessidade de atender às despesas extraordinárias não constitui o único motivo que pode induzir os responsáveis pela política econômica a optarem pelo crédito público. A contratação do empréstimo pode, também, destinar-se a outros fins e acarretar reflexos diretos sobre a poupança, a produção, oferta e demanda de crédito e, por conseguinte, sobre os interesses políticos, a economia e, não por menos, sobre o domínio econômico.

Saliente-se, ainda, que essa contratação pode, além disso, impactar gerações futuras, o que tem gerado, ainda hoje, muita discussão acerca da contratação de empréstimos pelo Estado; afinal, embora a dívida auxilie a obter mais cedo aquilo que se deseja, há os defensores da ideia de que os empréstimos repartem com as gerações futuras despesas públicas de hoje. Em outros termos, muitos questionam a legitimidade de se

\footnotetext{
${ }^{547}$ BALEEIRO, Aliomar. Uma introdução à ciência das finanças, p. 431.

${ }^{548}$ BUJANDA, Fernando Sainz de. Lecciones de derecho financeiro, p. 404.

${ }^{549}$ INGROSSO, Giovanni. Corso di finanza pubblica, p. 547.
} 
impor às gerações futuras o ônus de pagar as despesas públicas realizadas hoje e em favor das gerações que lhes antecedem.

Embora não constitua objeto de estudo da presente dissertação, defende-se que aqueles contrários à contratação de empréstimos desconsideram a necessidade de aumentar a flexibilidade orçamentária, a melhoria na gestão financeira, a possibilidade de antecipar receitas e, principalmente, a necessidade de dar continuidade à realização das despesas, mormente diante de eventual dificuldade ou queda na arrecadação de impostos.

Seus opositores também desconsideram a possibilidade de distribuir equitativamente, ao longo do tempo e por várias gerações, os custos decorrentes de investimentos que se perpetuarão no tempo, como é caso, v.g., de investimentos em infraestrutura e a realização de despesas de capital.

Essas despesas, ao corresponderem à aquisição de um ativo ao patrimônio público, podem gerar recursos, utilidades e benefícios para gerações atuais e futuras, ao contrário do alegado. Na visão de Aliomar Baleeiro ${ }^{550}$ :

\begin{abstract}
A geração futura ficaria onerada com a amortização, ou com os juros da dívida, mas receberia, como compensação desse ônus, o valor da rede de transportes, das empresas públicas produtivas de receitas originárias, das fortalezas, frotas mercantes de guerra, bens corpóreos etc. O sacrifício da posteridade seria praticamente nulo pelo ativo que se conservaria até a época em que viesse a suportar os ônus financeiros correspondentes.
\end{abstract}

Ricardo Lobo Torres, no entanto, adverte que "a equidade entre gerações significa que os empréstimos públicos e as despesas governamentais não devam sobrecarregar as gerações futuras, cabendo à própria geração que delas se beneficia arcar com o ônus respectivo" $" 551$.

Decorre das circunstâncias apontadas a razão pela qual o legislador brasileiro impôs limites à contratação de empréstimos (art. 167, II, da CF/1988), bem como vinculou as operações de crédito à sua exclusiva utilização de acordo com finalidade legal que as motivaram, ao introduzir o parágrafo único ao art. $8^{\circ}$ da LRF (Lei Complementar $n^{\circ} 101$, de 4 de maio de 2000).

\footnotetext{
${ }^{550}$ BALEEIRO, Aliomar. Uma introdução à ciência das finanças, p. 449.

${ }^{551}$ TORRES, Ricardo Lobo. Tratado de direito constitucional financeiro e tributário, p. 308-309.
} 
Tecidas essas considerações, há que se ressaltar que a contratação de empréstimos também tem por finalidade intervir na vida econômica e social, uma vez que, a captação de recursos pode estar atrelada à necessidade de fomentar determinada(s) atividade(s) ou setor(es), e até mesmo estimular o crescimento econômico em períodos de recessão.

De acordo com cada motivação, a qual também envolvem circunstâncias pessoais e as paixões daqueles que governam o País, a dívida pública assume um papel diferente. Importante instrumento de que dispõe o Estado para intervir no domínio econômico e social, concretizar sua política financeira e promover o crescimento econômico, é por meio da dívida pública que o Estado, em períodos de recessão, crise ou decréscimo de arrecadação, mantém a política de obras públicas que, sem essa contração de dívida, seriam paralisadas ou até mesmo deixariam de ser executadas ${ }^{552}$.

Nesse aspecto, ganham destaque as ideias keynesianas por colocar em relevo a importância da despesa pública como providência restauradora do consumo, influenciar a decisão de investir e por tornar desaconselhável a tributação violenta, atribuindo aos empréstimos a função de captar recursos para sustentar a política de gastos intensos com o fim de recuperar a prosperidade, o que pode não se alacançar com a majoração ou criação de novos tributos 553 .

Além dos fatores apontados, John Maynard Keynes também atribui ao clima político e social a prosperidade econômica, assinalando que "o fato de o temor a um governo trabalhista ou de um New Deal deprimir o empreendimento não é necessariamente consequência de um cálculo racional ou de manobras com fins políticos" ${ }^{\text {5 }}$.

Com isso, tem-se que a adoção de determinadas medidas ou escolhas também pode influenciar a economia e o domínio econômico em específico. Ao optar por tomar um empréstimo ao invés de aumentar a carga tributária, certamente reações diversas na economia serão provocadas.

Fernando Sainz de Bujanda ${ }^{555}$ faz uma observação precisa, ao ponderar:

\footnotetext{
${ }^{552}$ BALEEIRO, Aliomar. Uma introdução à ciência das finanças, p. 453.

${ }^{553}$ Ibidem, loc. cit.

${ }^{554}$ KEYNES, John Maynard. Teoria geral do emprego, do juro e da moeda, p. 145.

${ }^{555}$ BUJANDA, Fernando Sainz de. Lecciones de derecho financiero, p. 404.
} 
Y no sólo motivos puramente económicos pueden influir en la decisión de emitir títulos de la Deuda. Las ideas del legislador sobre el reparto de las cargas públicas, tanto en el espacio como en el tiempo, las consecuencias sociales (creación de una classe de rentistas, fomento de ahorro, ect.) y las motivaciones de índole política (ventajas e inconvenientes del endeudamiento frente a otro Estado, etc.) pueden determinar la elección de uno u otro método (Deuda, impuesto, etc.) de subvenir a las cargas del Estado.

Richard A. Musgrave, nesse aspecto, também traz algumas distinções.

[...] a escolha entre financiamento por tomada de empréstimo e o que é feito por tributação envolve uma escolha entre retirada de recursos em grande parte da formação de capital privado e uma outra grande parte do consumo privado. Uma política fiscal que tem por alvo acentuar o crescimento confia no financiamento por coleta de impostos, ao passo que a destinada a suportar o consumo presente se apóia no financiamento por empréstimo ${ }^{556}$.

Sem dúvidas, as decisões adotadas pela Administração Pública mexem com a expectativa da iniciativa privada, esquecendo-se, muitas vezes, que "a solvência governamental depende dos poderes produtivos da economia e da capacidade tributável que abrangem, 557 .

Concebe-se, com isso, que o crédito público é um forte instrumento à disposição do Estado para o controle do mercado monetário e de desenvolvimento econômico, social e financeiro, desde que ele, Estado, o utilize de modo responsável e consciente, e em atendimento às próprias finalidades.

\footnotetext{
${ }^{556}$ MUSGRAVE, Richard A. Teoria das finanças públicas, p. 690.

${ }^{557}$ Ibidem, p. 696.
} 


\section{CONCLUSÕES}

Com base no estudo do texto constitucional e no exame dos pressupostos do Direito do Estado, Financeiro e Econômico realizados, e levando-se em conta que o objeto de análise proposto, inicialmente, consiste na relação estabelecida entre o Estado e a sociedade a partir da peça orçamentária, bem como sua utilização como instrumento de intervenção no domínio econômico, a presente dissertação pode ser sintetizada nas conclusões que se seguem, sem prejuízo de outras lançadas ao longo do texto.

Conforme apontado, tudo se inicia quando o Estado, com os propósitos de colocar em ordem a vida econômica e social, passa a intervir direta e indiretamente no domínio econômico ou, como se disse, passa a figurar como agente normativo e regulador da atividade econômica em detrimento de uma suposta livre iniciativa, que nunca fora absoluta.

Dotado de força e poder suficientes para impor a realização de determinados comportamentos, o Estado passa a participar diretamente da economia e a atuar de maneira a assegurar o exercício racional das liberdades individuais, alargando suas obrigações e, com isso, a necessidade de obter mais recursos financeiros para alcançar o bem social.

Daí por diante o orçamento público ganha relevância, cujos primeiros traços são marcados pelo surgimento do Estado e a necessidade de aferir recursos que, com o passar do tempo, deixaram de ser obtidos à força pelo soberano e começaram a ser extraídos do povo, com o seu consentimento.

Surge, assim, o consentimento à tributação e, logo após, a necessidade de autorização para se realizar o gasto público, cuja função fora originariamente atribuída ao Legislativo como forma de exercer controle sobre o Executivo.

Além da função de controle atribuída ao Legislativo, com o passar do tempo, verifica-se que novas e relevantes funções são incorporadas ao orçamento público, destacando-se, dentre elas, a instrumentalização administrativa ou gerencial - por meio da qual as técnicas modernas de administração e a busca dos resultados pretendidos pela ação governamental passam a ser aplicadas no orçamento - e a instrumentalização fiscal, com a qual se materializam determinados fins de política fiscal do Governo. 
As funções mencionadas decorrem, assim, da própria redefinição do papel do Estado, e da adoção de uma teoria constitucional econômica e financeira compatível com seus atuais desígnios, em que a preocupação maior é o bem-estar social, consagrando a Constituição Federal de 1988, dentre seus fins, a atividade financeira do Estado, a gestão do patrimônio e o controle das contas públicas.

Com isso, o Estado tem de exercer, na qualidade de agente normativo e regulador da atividade econômica, as funções de fiscalização, incentivo e planejamento. Cabe ao planejamento prever comportamentos econômicos e sociais futuros, formular explicitamente objetivos e definir as ações que serão desencadeadas com o propósito de atingi-los.

Para tanto, o Estado passa a utilizar o orçamento público como instrumento de intervenção no domínio econômico, conformando, dirigindo, induzindo e fomentando a atividade desenvolvida pela iniciativa privada, já que sua principal característica constitui a realização de um programa, e o torna verdadeiro instrumento de planejamento, de direção e de controle da Administração Pública.

Composto por um conjunto de normas jurídicas, veiculadas por leis específicas e complementares, ou seja, as leis orçamentárias - Plano Plurianual (PPA), Lei Orçamentária Anual (LOA) e Lei de Diretrizes Orçamentárias (LDO) -, o orçamento público tem por finalidade autorizar as despesas, segundo as estimativas de receitas, concretizar direitos fundamentais e, ainda, instituir e perseguir metas, diretrizes, objetivos, programas ou políticas públicas com função de planejamento, de modo a assegurar sua efetividade.

Neste contexto, afasta-se a tese de que o orçamento consista em um simples ato administrativo e passa a preponderar seu caráter de "ato-condição", pois vinculada está a Administração Pública à observância dos limites nele estabelecidos, tanto quanto à realização das diretrizes, objetivos e metas estabelecidas no plano plurianual, decorrente do planejamento traçado na lei de diretrizes orçamentárias e na lei orçamentária anual.

Corrobora essa assertiva, o fato de referidas leis serem compostas por uma série de comandos que se traduzem em autorizações, proibições e determinações, que não podem ser simplesmente desconsideradas pelos governantes do País.

O plano de atuação estabelecido pelo Estado possibilita a identificação dos propósitos econômicos e sociais a serem perseguidos, de que forma e onde os recursos públicos serão gastos, permitindo à iniciativa privada tomar conhecimento das diretrizes 
estatais e, com isso, também se programar e planejar suas atividades em consonância com os planos do Estado.

Assim, é possível identificar quais os propósitos do Estado, cujos objetivos traduzir-se-ão em atos de intervenção direta, que se destinam à direção e controle das atividades econômicas privadas, na qualidade de agente fiscalizador - função de polícia - e de intervenção indireta, em que o Estado age de maneira a estimular e fomentar o domínio econômico, devendo sempre, em qualquer modo de intervenção, respeitar a lei com o propósito de atender aos interesses públicos.

Para tanto, basta lembrar que o Estado, ao se propor a dirigir ou regular determinados comportamentos, dispõe das receitas extraordinárias e do caráter extrafiscal das receitas públicas tributárias. Afinal, no quadro das finanças públicas contemporâneas do dirigismo, o Estado pretende obter da sua atividade financeira fins de ordem socioeconômica e não apenas arrecadar receitas para intervir no domínio econômico.

Com a obtenção de receitas extraordinárias e, portanto, com a contração da dívida pública, o Estado promove a redistribuição do capital e da renda, realiza investimentos de curto e longo prazos em infraestrutura, saneamento básico, educação saúde etc., aplicando no desenvolvimento socioeconômico.

A extrafiscalidade torna possível manejar elementos jurídicos usados na configuração dos tributos e perseguir objetivos alheios aos meramente arrecadatórios. Verifica-se a possibilidade de o Estado prestigiar certas situações sociais, políticas ou econômicas em que, ao aumentar a carga tributária, inibe e até mesmo impede a prática de determinados atos pela iniciativa privada e, de outro modo, reduzindo-a, com a concessão de isenção, subvenção e até mesmo com a renúncia de receita, induz e incentiva todo o setor produtivo ou determinadas atividades, privilegiando-as.

Além disso, na intervenção por indução ou de fomento, o Estado, da mesma forma, e por meio do orçamento público, promove o desenvolvimento da economia, favorece a iniciativa privada criando estímulos ou incentivos que forcem os agentes a adotar determinadas condutas impossíveis de serem implementadas, caso não existisse a intervenção estatal.

Com a realização do gasto público opera-se o incremento na renda nacional e, consequentemente, verifica-se o aumento do consumo e do investimento na economia; 
desse modo, o Estado intervém, quer estimulando, quer induzindo as empresas a melhorarem ou expandirem sua capacidade produtiva, a qual se verificará com a realização de investimentos em máquinas, instalações, equipamentos, ampliação de estoques, contratação de novos funcionários etc..

Cria-se, no empreendedor e em toda a iniciativa privada, no mínimo, uma expectativa de que as despesas eleitas serão realizadas e, consequentemente, a expectativa de disponibilização de recursos para investimentos, realização de obras de infraestrutura, concessão de benefícios a determinadas regiões e setores da economia etc., motivando-os a investir em determinadas atividades, projetos e inovações.

É imperioso, portanto, que as despesas sejam efetuadas de acordo com a previsão orçamentária, na medida em que representam os anseios da sociedade, garantindo àqueles que exercem qualquer atividade econômica em sentido estrito, diante do planejamento instituído pelo Estado, imunidade em relação às manobras, titubeios ou qualquer tergiversação do Governo, as quais estão sujeitas não apenas às oscilações do mercado, da macro e da microeconomia, mas, também, às paixões e à ideologia daqueles que dirigem o País.

A decisão de gastar é, pois, fundamentalmente política e, por consequência, está sujeita à vontade, aos desejos, à libido, enfim, às paixões dos administradores, não restando dúvidas de que as decisões tomadas em relação à peça orçamentária também sejam motivadas por interesses particulares, por crueldade ou por justiça, por sabedoria ou por temor.

Qualquer mudança na realização dos planos de ação do Estado, ao contrário do quanto se prega ao reconhecer que este não constitui mero ato administrativo, deveria darse de forma motivada, pois somente assim seria atribuído ao orçamento público o papel de verdadeiro instrumento de intervenção no domínio econômico, conferindo-lhe maior segurança jurídica e ética à elaboração e execução orçamentária.

Para tanto, impõe-se a relativização da discricionariedade e a construção de um processo orçamentário mais sério e responsável, capaz de afastar ou minimizar a influência das paixões e ideologias de determinados grupos ou pessoas, dotando-o de maior eficiência em busca de um empreendimento do dinheiro público mais eficiente, o qual deve estar comprometido com o propósito de melhor atender aos anseios da sociedade, ou seja, à satisfação das necessidades coletivas. 
Afinal, e ainda que o Estado, ou aqueles que o representam, eleja qualquer uma das formas ou critérios de intervenção, seja pela absorção, participação, direção, fomento ou indução, a escolha estará sempre sujeita aos interesses pessoais daquele que detém referido mister.

Com base nessas pressuposições, o Estado intervém indiretamente no domínio econômico, conduzindo e conformando comportamentos, conforme restou demonstrado no texto da presente dissertação, ao tratar das receitas, despesas públicas e do crédito público. De alguma maneira, todas as classificações doutrinárias inerentes ao modo de intervenção do Estado no domínio econômico se correlacionam com os pressupostos orçamentários e detêm o poder de impactar as atividades desenvolvidas pelos particulares de forma a restringi-las, incentivar, estimular ou fomentar.

Em outras palavras, pode-se afirmar que o Estado se vale do orçamento público para intervir no domínio econômico com a finalidade de produzir resultados macro ou microeconômicos, diversos daqueles que adviriam caso não houvesse a intervenção, pois, ao praticá-la, persegue a alteração de parâmetros comportamentais originários do mercado no qual intervém, seja de forma promocional, restritiva ou repressiva. 


\section{REFERÊNCIAS}

ALMEIDA, Carlos Otávio Ferreira de. O planejamento financeiro responsável: boa governança e desenvolvimento do Estado contemporâneo. In: CONTI, José Mauricio; SCAFF, Fernando Facury (Coords.). Orçamentos públicos e direito financeiro. São Paulo: Revista dos Tribunais, 2011.

ALVES, Henrique Eduardo. Orçamento respeitosamente impositivo. Folha de S. Paulo. São Paulo, 14 abr. 2013. Seção Tendências/Debates, p. A3.

ARAGÃO, Alexandre Santos de. O serviço público e as suas crises. In: ARAGÃO, Alexandre Santos de; MARQUES NETO, Floriano de Azevedo (Coord.). Direito administrativo e seus novos paradigmas. Belo Horizonte: Fórum, 2008.

ASSONI FILHO, Sérgio. Crédito público e responsabilidade fiscal. Porto Alegre: Nuria Fabris, 2007.

ATALIBA, Geraldo. Hipótese de incidência tributária. 6. ed. São Paulo: Malheiros, 2000. . Empréstimos públicos e seu regime jurídico. São Paulo: RT, 1973. - Apontamentos das ciências das finanças, direito financeiro e tributário. São Paulo: Revista dos Tribunais, 1969. . Sistema constitucional tributário brasileiro. São Paulo: Revista dos Tribunais, 1968.

BALEEIRO, Aliomar. Uma introdução à ciência das finanças. 14. ed. atual. por Flávio Bauer Novelli. Rio de Janeiro: Forense, 2004.

Direito tributário brasileiro. 11. ed., rev. e complem. por Misabel Abreu Machado Derzi. Rio de Janeiro: Forense, 2001.

BARROSO, Luís Roberto. Modalidades de intervenção do Estado na ordem econômica. Regime jurídico das sociedades de economia mista. Inocorrência de abuso de poder. In: . Temas de direito constitucional. Rio de Janeiro: Renovar, 2001.

BASTOS, Celso Ribeiro. Curso de direito constitucional. 22. ed. rev. e atual. por Samantha Meyer-Pflug. São Paulo: Malheiros, 2010.

BASTOS, Celso Ribeiro; MARTINS, Ives Gandra da Silva. Comentários à Constituição do Brasil: promulgada em 5 de outubro de 1988. São Paulo: Saraiva, 1988. v. 7.

BECKER, Alfredo Augusto. Teoria geral do direito tributário. 3. ed. São Paulo: Lejus, 2002. 
BENETON, Marco Antonio Hatem. O plano plurianual, os contratos administrativos e a teoria do diálogo das fontes: os exemplos de elos entre o direito financeiro e o direito administrativo. In: CONTI, José Mauricio; SCAFF, Fernando Facury (Coords.). Orçamentos públicos e direito financeiro. São Paulo: Revista dos Tribunais, 2011. São Paulo: Revista dos Tribunais, 2011.

BERCOVICI, Gilberto. Constituição econômica e desenvolvimento: uma leitura a partir da Constituição de 1988. São Paulo: Malheiros, 2005.

. Constituição e estado de exceção permanente: atualidade de Weimar. Rio de Janeiro: Azougue, 2004a.

$2004 b$.

Dilemas do estado federal brasileiro. Porto Alegre: Livraria do Advogado,

- O planejamento e a Constituição de 1988. In: SCAFF, Fernando Facury (Coord.). Constitucionalizando direitos: 15 anos da constituição brasileira de 1988. Rio de Janeiro: Renovar, 2003.

. Os princípios orçamentários e a primeira Constituição republicana. Revista de Direito Internacional e Econômico, Porto Alegre, v. 1, n. 1, out./dez. 2002.

BEREIJO, Álvaro Rodríguez. La configuración constitucional de las leyes de presupuestos generales del estado. Valadolid: Lex Nova, 1988.

. Orçamento - I. Revista de Direito Público, n. 94, p. 18-43, abr./jun. 1990.

. Orçamento - II. Revista de Direito Público, n. 95, p. 5-18, jul./set. 1990.

Orçamento - III. Revista de Direito Público, n. 96, p. 5-41, out./dez. 1990.

BONAVIDES, Paulo. Curso de direito constitucional. 23. ed. São Paulo: Malheiros, 2008.

BONAVIDES, Paulo; ANDRADE, Paes de. História constitucional do Brasil. 8. ed. Brasília: OAB, 2006.

História constitucional do Brasil. 5. ed. Brasília: OAB, 2004.

BRASIL. Ministério do Planejamento, Orçamento e Gestão; Secretaria de Orçamento Federal. Ementário de receitas da União. Disponível em: $<$ http://www.orcamentofederal.gov.br/informacoes-orcamentarias/arquivos-receitaspublicas/receitas-publicas>. Acesso em: 12 nov. 2014.

BRESSER-PEREIRA, Luiz Carlos. Burocracia pública e reforma gerencial. Revista do Serviço Público, Brasília, p. 29-48, ed. esp. de 2007.

Da administração pública burocrática à gerencial. In: BRESSER-PEREIRA, Luiz Carlos; SPINK, Peter Kevin. Reforma do estado e administração pública gerencial. 6. ed. Rio de Janeiro: FGV, 2005.

BUJANDA, Fernando Sainz de. Lecciones de derecho financiero. 7. ed. Madrid: Universidad Complutense; Facultad de Derecho, Sección de Publicaciones, 1989. 
BUJANDA, Fernando Sainz de. Hacienda y Derecho. Madrid: Instituto de Estudios Políticos, 1955.

CAMPOS, Francisco. Natureza jurídica do orçamento. Revista de Direito Administrativo, n. 71, 1963.

CARDONA, Alejandro Ramirez. Sistema de hacienda pública. Bogotá: Temis, 1970.

CARRIÓ, Genaro. Notas sobre derecho y lenguaje. 4. ed. Buenos Aires: Abeledo-Perrot, 1990.

CARVALHO, André Castro. Vinculação de receitas públicas. São Paulo: Quartier Latin, 2010.

CARVAlHO, Paulo de Barros. Curso de direito tributário. 13. ed. São Paulo: Saraiva, 2000.

CATARINO, João Ricardo. Finanças públicas e direito financeiro. Coimbra: Almedina, 2012.

CHAUÍ, Marilena. Manifestações ideológicas do autoritarismo brasileiro. Organizado por André Rocha. Belo Horizonte: Autêntica; São Paulo: Fundação Perseu Abramo, 2013. (Escritos de Marilena Chauí, 2).

CONTI, José Maurício. E o ano começa sem a aprovação do orçamento federal. Consultor Jurídico. Contas à vista. Publicado em 15 jan. 2013. Disponível em: <http://www.conjur.com.br/2013-jan-15/contas-vista-ano-comeca-aprovacao-orcamentofederal>. Acesso em: 6 out. 2014.

Orçamento impositivo é avanço para administração. Consultor Jurídico, 7 maio 2013. Disponível em: <http://conjur.com.br/2013-maio-07/contas-vista-orcamentoimpositivo-avanco-adminstracao>. Acesso em: 6 out. 2014.

Planejamento municipal precisa ser levado a sério. Consultor Jurídico, 24 set. 2013. Disponível em: <http://www.conjur.com.br/2013-set-24/contas-vista-planejamentomunicipal-levado-serio>. Acesso em: 8 out. 2014.

Planejamento e responsabilidade fiscal. In: SCAFF, F. F.; CONTI, José Maurício. Lei de Responsabilidade Fiscal. 10 anos de vigência - questões atuais. São Paulo: Conceito, 2010.

. A autonomia financeira do poder judiciário. São Paulo: MP Editora, 2006.

Direito financeiro na Constituição de 1988. São Paulo: Oliveira Mendes, 1998.

CORIGLIANO, Rogério de Menezes. Empréstimos públicos. 2003. Dissertação (Mestrado) - Faculdade de Direito da Universidade de São Paulo, São Paulo, 2003.

CORTI, Horacio Guillermo. Derecho constitucional presupuestario. 2. ed. Buenos Aires: Abeledo Perrot, 2011. 
DALLARI, Adilson Abreu. Orçamento impositivo. In: CONTI, José Mauricio; SCAFF, Fernando Facury (Coords.). Orçamentos públicos e direito financeiro. São Paulo: Revista dos Tribunais, 2011.

DALLARI, Dalmo de Abreu. Elementos de teoria geral do estado. 31. ed. São Paulo: Saraiva, 2012.

DEODATO, Alberto. Manual de ciência das finanças. 17. ed. São Paulo: Saraiva, 1980.

As funções extra-fiscais do imposto. 1949. Tese (Concurso de Professor Catedrático de Ciência das Finanças) - Faculdade de Direito da Universidade de Minas Gerais, Belo Horizonte, 1949.

DI PIETRO, Maria Sylvia Zanella. Direito administrativo. 26. ed. São Paulo: Atlas, 2013.

DRAGO, Luis María. Cobro coercitivo de deudas públicas. Buenos Aires: Coni Hermanos, 1906.

DUGUIT, Léon. Les transformations du droit public. Paris: A. Colin, 1913.

ECHEVARRÍA, Santiago García. Política de subvenciones (la inspección financiera en el sector mixto de la economía). Paper n. 15. Universidad de Alcal/Instituto de Direción y Organización de Empresas (IDOE), 1983. Disponível em: <http://dspace.uah.es/dspace/handle/10017/3074>. Acesso em: 5 jun. 2014.

FALCÃO, Amílcar de Araújo. Introdução ao direito tributário. Rio de Janeiro: Ed. Financeiras, 1955. FALCÃO, Amílcar de Araújo. Natureza dos empréstimos públicos. Revista de Direito Público, ano IV, v 13, jul.-set. 1973.

FERREIRA FILHO, Manoel Gonçalves. A intervenção do estado no domínio econômico e a Constituição de 1988. Revista do Tribunal Regional Federal: $4^{\underline{a}}$ Região, ano 24, n. 82, p. 61-74, 2013.

Curso de direito constitucional. 38. ed. rev. e atual. São Paulo: Saraiva, 2012.

FIGUEIREDO, Leonardo Vizeu. Lições de direito econômico. 3. ed. Rio de Janeiro: Forense, 2010.

FIGUEIREDO, Lúcia Valle. Reflexões sobre a intervenção do estado no domínio econômico e as contribuições interventivas. In: MACHADO, Hugo de Brito (Coord.). As contribuições no sistema tributário brasileiro. São Paulo: Dialética / Fortaleza: Instituto Cearense de Estudos Tributários, 2003.

FONROUGE, Carlos M. Giuliani. Derecho financiero. 3. ed. Buenos Aires: Depalma, 1977. v. I.

FOUCAULT, Michel. Microfísica do poder. Organização, introdução e revisão técnica de Roberto Machado. 25. ed. São Paulo: Graal, 2012.

- Segurança, território, população: curso dado no Collège de France (19771978). Tradução de Eduardo Brandão e revisão de Claudia Berliner. São Paulo: Martins Fontes, 2008. 
FRANCO, Gustavo H. B.; FARNAM, Henry W. Shakespeare e a economia. Rio de Janeiro: Zahar, 2009.

FREIRE, Paulo. Pedagogia do oprimido. Rio de Janeiro: Nova Fronteira, 2012.

FREUD, Sigmund. $O$ mal-estar na cultura. Tradução de Renato Zwick; revisão técnica e prefácio de Márcio Seligmann-Silva; ensaio bibliográfico de Paulo Endo e Edson Souza. Porto Alegre: L\&PM, 2011.

GIACOMONI, James. O orçamento público. 14. ed. São Paulo: Atlas, 2007.

GIORGETTI, Armando. Lezioni di scienza delle finanze e di diritto finanziario. Padova: Dott. Antonio Milani, 1972.

GOMES, Émerson César da Silva. Das autarquias e outras entidades. In: CONTI, José Maurício. Orçamentos públicos: a lei 4.320/1964 comentada. 2. ed. São Paulo: Revista dos Tribunais, 2010.

GONZÁLEZ, Luis Manuel Alonso. Los impuestos autonómicos de caracter extrafiscal. Madrid: Marcial Pons, 1995.

GRAÇA, Luís Otávio Barroso da. Orçamento impositivo: uma análise à luz da economia política. 2003. 79 f. Dissertação (Mestrado em Economia do Setor Público) - Universidade de Brasília $\quad-\quad$ UnB, 2003. Disponível em: <http://www2.senado.gov.br/bdsf/item/id/88438>. Acesso em: 22 abr. 2013.

GRAU, Eros Roberto. O direito posto e o direito pressuposto. 8. ed. São Paulo: Malheiros, 2011.

2010. A ordem econômica na Constituição de 1988. 14. ed. São Paulo: Malheiros,

GRIZIOTTI, Benvenuto. Principios de ciência de las finanzas. 6. ed. Buenos Aires: Depalma. 1959.

GROTTI, Dinorá Adelaide Museti. Teoria dos serviços públicos e sua transformação. In: SUNDFELD, Carlos Ari. Direito administrativo e econômico. 3. tiragem. São Paulo: Malheiros, 2006.

2003. O serviço público e a Constituição Brasileira de 1988. São Paulo: Malheiros,

GUERRA, Sérgio. Discricionariedade administrativa - limitações da vinculação legalitária e propostas pós-positivistas. In: ARAGÃO, Alexandre Santos de; MARQUES NETO, Floriano de Azevedo (Coord.). Direito administrativo e seus novos paradigmas. Belo Horizonte: Fórum, 2008.

HOBBES, Thomas. Leviatã, ou matéria, forma e poder de um estado eclesiástico e civil. Traduzido por Rosina D’ Angina. 2. ed. São Paulo: Martin Claret, 2012. (Coleção A obra prima de cada autor). 
HOLANDA, Sérgio Buarque de. Raízes do Brasil. 26. ed. São Paulo: Companhia das Letras, 2012.

HORVATH, Estevão. $O$ orçamento no século XXI: tendências e expectativas. 2014. Tese (Concurso de Professor Titular de Direito Financeiro) - Faculdade de Direito da Universidade de São Paulo, São Paulo, 2014.

Orçamento público e planejamento. In: MELLO, Celso Antônio Bandeira de (Org.). Estudos em homenagem a Geraldo Ataliba - direito tributário. São Paulo: Malheiros, 1997.

HORVATH, Estevão; OLIVEIRA, Regis Fernandes de. Manual de direito financeiro. 6. ed. São Paulo: Revista dos Tribunais, 2003.

INGROSSO, Giovanni. Corso di finanza pubblica. Napoli: Dott Eugenio Jovene, 1969. Diritto finanziario. Napoli: Jovene, 1956.

JÈZE, Gaston. Principios generales del derecho administrativo. Traduzido para o espanhol por Julio N. San Millán Almagro. Buenos Aires: Depalma, 1949. v. II, t. I, p. 4. Tradução da 3. ed. francesa: Les principes généraux du droit administratif.

. Traité de science des finances: le budget... Paris: V. Giard \& Brière, 1910. t. I.

KEYNES, John Maynard. Teoria geral do emprego, do juro e da moeda. Tradução de Manuel Resende. São Paulo: Saraiva, 2012.

LABAND, Paul. Le droit public de l'empire allemand. Paris: Giard \& Brière, 1904. v. VI.

LAUBADÈRE, André de. Direito público económico. Traduzido por Maria Teresa Costa; revisto por Evaristo Mendes. Coimbra: Almedina, 1985.

MAQUIAVEL, Nicolau. O príncipe. 22. reimpressão. Tradução de Maria Lucia Cumo. Rio de Janeiro: Paz e Terra, 1996.

MASSONETTO, Luís Fernando. O direito financeiro no capitalismo contemporâneo: a emergência de um novo padrão normativo. 2006. Tese (Doutorado) - Universidade de São Paulo, São Paulo, 2006.

MATIAS-PEREIRA, José. Finanças públicas: a política orçamentária no Brasil. 3. ed. São Paulo: Atlas, 2006.

MEDAUAR, Odete. Direito administrativo moderno. 16. ed. São Paulo: Revista dos Tribunais, 2012.

2003.

O direito administrativo em evolução. 2. ed. São Paulo: Revista dos Tribunais,

MEIRELLES, Hely Lopes. Direito administrativo brasileiro. 28. ed. São Paulo: Malheiros, 2003. 
MELlo, Celso Antônio Bandeira de. Curso de direito administrativo. 28. ed. São Paulo: Malheiros, 2011.

MENEZES, Anderson de. Teoria geral do estado. Rio de Janeiro: Forense, 1960.

MICHELI, Gian Antonio. Corso di diritto tributario. Torino: UTET, 1976.

MONCADA, Luís S. Cabral de. Direito económico. 5. ed. revista e actualizada. Lisboa: Coimbra, 2007.

MORAES, Alexandre de. Direito constitucional. 29. ed. São Paulo: Atlas, 2013.

MOREIRA, Egon Bockmann. O direito administrativo contemporâneo e a intervenção do Estado no domínio econômico. In: WAGNER JUNIOR, Luiz Guilherme da Costa (Coord.). Direito público: estudos em homenagem ao professor Adilson de Abreu Dallari. Belo Horizonte: Del Rey, 2004.

MOREIRA, Vital. Economia e Constituição. 2. ed. Lisboa: Coimbra, 1979.

MUSGRAVE, Richard A. Teoria das finanças públicas. São Paulo: Atlas, 1974. v. 2.

NASCIMENTO, Tupinambá Miguel Castro do. Comentários à Constituição Federal: ordem econômica e financeira. Porto Alegre: Livraria do Advogado, 1997.

NUSDEO, Fábio. Curso de economia: introdução ao direito econômico. 6. ed. São Paulo: Revista dos Tribunais, 2010.

OLIVEIRA, José Marcos Domingues de. O desvio de finalidade das contribuições e o seu controle tributário e orçamentário no direito brasileiro. In: (Coord.). Direito tributário e políticas públicas. São Paulo: MP Editora, 2008.

OLIVEIRA, Regis Fernandes de. Gastos públicos. São Paulo: Revista dos Tribunais, 2012a.

Infrações e sanções administrativas. 3. ed. rev., atual. e ampl. São Paulo: Revista dos Tribunais, 2012 b.

Tribunais, 2011.

Curso de direito financeiro. 4. ed. rev. atual. e ampl. São Paulo: Revista dos

Deve o orçamento ser cumprido? Jus Navegandi, Teresina, ano 9, n. 672, 8 de maio de 2005. Disponível em: <http://jus.com.br/revista/texto/6698/deve-o-orcamento-sercumprido>. Acesso em: 22 abr. 2013.

Responsabilidade fiscal. 2. ed. São Paulo: Revista dos Tribunais, 2002.

. Empréstimos públicos no Brasil. In: MELLO, Celso Antônio Bandeira de (Org.). Estudos em homenagem a Geraldo Ataliba: direito tributário. São Paulo: Malheiros, 1997. v. I.

OLIVEIRA, Weder de. Curso de responsabilidade fiscal: direito, orçamento e finanças públicas. Belo Horizonte: Fórum, 2013. 
ORÍA, Salvador. Finanzas. Buenos Aíres: Guillermo Kraft, 1948. v. 3.

PEDRAS, Guilherme Binato Villela. História da dívida pública no Brasil: de 1964 até os dias atuais. SILVA, Anderson Caputo; CARVALHO, Lena Oliveira de; MEDEIROS, Otavio Ladeira de (Orgs.). A dívida pública: a experiência brasileira. Brasília: Secretaria do Tesouro Nacional; Banco Mundial, 2009. Disponível em: <http://www3.tesouro.gov.br/divida_publica/downloads/livro/livro_eletronico_completo.p df>. Acesso em: 26 ago. 2013.

POPHAM, Peter. The price of food is at the heart of this wave of revolutions. The Independent, Londres, 27 fev. 2011. Disponível em: <http://www.independent.co.uk/news/word/africa/the-price-of-food-is-at-the-heart-of-thiswave-of-revolutions-2226896.html>. Acesso em: 23 jun. 2014.

RIVERO, Jean. Hauriou et l'avènement de la notion de service public. In: MESTRE, Melanges. L'evolution du driot public: études en l'honneur d'Achilles Mestre. Paris: Sirey, 1956.

ROSEMBUJ, Tulio. Elementos de derecho tributario. In: GONZÁLEZ, Luis Manuel Alonso. Los impuestos autonómicos de caracter extrafiscal. Madrid: Marcial Pons, 1995.

ROUSSEAU, Jean-Jacques. Do contrato social. Tradução de Eduardo Brandão; organização e introdução de Maurice Cranston. São Paulo: Penguin Classics/Companhia das Letras, 2011.

ROYO, Fernando Pérez. Derecho financiero y tributario: parte general. 20. ed. Sevilla: Thomson Reuters, 2010.

RUBINSTEIN, Flávio. Boa-fé objetiva no direito financeiro e no direito tributário brasileiros. 2008. 213 f. Dissertação (Mestrado) - Universidade de São Paulo, São Paulo, 2008.

SARASOLA GORRITI, Silbia. La concesión de servicios públicos municipales: estudio especial de las potestades de intervención. Oñati: IVAP, 2003.

SCAFF, Fernando Facury. Responsabilidade civil do estado intervencionista. 2. ed. São Paulo: Renovar, 2001.

SCHOPENHAUER, Arthur. $O$ mundo como vontade e representação. Tradução de M. F. Sá Correia. 4. reimpressão. Rio de Janeiro: Contraponto, 2001.

SCHOUERI, Luís Eduardo. Normas tributárias indutoras e intervenção econômica. Rio de Janeiro: Forense, 2005.

SEGUNDO, Rinaldo. Breves considerações sobre o orçamento público. Jus Navegandi, 2002. Disponível em: <http://jus.com.br/revista/texto/4505/breves-consideracoes-sobre-oorcamento-publico>. Acesso em: 30 jun. 2013.

SILVA, Anderson Caputo. Origem e história da dívida pública brasileira. In: SILVA, Anderson Caputo; CARVALHO, Lena Oliveira de; MEDEIROS, Otavio Ladeira de (Orgs.). A divida pública: a experiência brasileira. Brasília: Secretaria do Tesouro Nacional; Banco $2009 . \quad$ Dundial, em: 
<http://www3.tesouro.gov.br/divida_publica/downloads/livro/livro_eletronico_completo.p df>. Acesso em: 26 ago. 2013.

SILVA, José Afonso da. Comentário contextual à Constituição. 6. ed. São Paulo: Malheiros, 2009.

Curso de direito constitucional positivo. 19. ed. São Paulo: Malheiros, 2001. Orçamento programa no Brasil. São Paulo: Revista dos Tribunais, 1973.

SOUZA, Rubens Gomes de. Compêndio de legislação tributária. Coord. IBET - Instituto Brasileiro de Estudos Tributários; obra póstuma. São Paulo: Resenha Tributária, 1975.

SPINOZA, Baruch de. Tratado político. Tradução e prefácio de José Pérez. Ed. especial. Rio de Janeiro: Nova Fronteira, 2013.

SUNDFELD, Carlos Ari. Fundamentos de direito público. 3. ed. São Paulo: Malheiros, 1997.

SUNDFELD, Carlos Ari; VIEIRA, Oscar Vilhena. Direito global. São Paulo: Max Limond, 1999.

TORRES, Heleno Taveira. Teoria da Constituição financeira. 2013. Tese (Concurso público de títulos e provas para o provimento do cargo de Professor Titular de Direito Financeiro) - Faculdade de Direito da Universidade de São Paulo, São Paulo, 2013.

TORRES, Ricardo Lobo. Curso de direito financeiro e tributário. 18. ed. Rio de Janeiro: Renovar, 2011.

- Tratado de direito constitucional, financeiro e tributário: o orçamento na Constituição. 3. ed. Rio de Janeiro: Renovar, 2008. v. V.

VILLEGAS, Héctor Belisario. Curso de finanzas, derecho financiero y tributario. 9. ed. Buenos Aires: Depalma, 2007.

Depalma, 1990. t. I.

Curso de finanzas, derecho financiero y tributario. 4. ed. Buenos Aires:

WEBER, Max. O direito na economia e na sociedade. Tradução de Marsely De Marco Martins Dantas. São Paulo: Ícone, 2011.

Economia e sociedade. Trad. de Regis Barbosa e Karen Elsabe Barbosa, rev. téc. de Gabriel Cohn. Reimpressão. Brasília: Editora Universidade de Brasília, 1999. v. II.

Economia e sociedade: fundamentos da sociologia compreensiva. Trad. por Regis Barbosa e Karen Elsabe Barbosa; rev. téc. de Gabriel Cohn. Brasília: Reimpressão. Editora Universidade de Brasília, 1999, 2009. v. I.

ZANCHIM, Kleber Luiz. Capítulo III - da despesa: arts. 12 a 21. In: CONTI, José Maurício (Coord.). Orçamentos públicos: a lei 4.320/1964 comentada. 2. ed. São Paulo: Revista dos Tribunais, 2010. 


\section{Sites/Links}

http://g1.globo.com

http://www.camara.gov.br

http://www.mda.gov.br

http://www.orcamentofederal.gov.br

http://www.planejamento.gov.br

http://www.stf.jus.br

http://www.tesouro.fazenda.gov.br

http://www2.camara.leg.br

http://www3.tesouro.fazenda.gov.br

www.legislacao.planalto.gov.br 